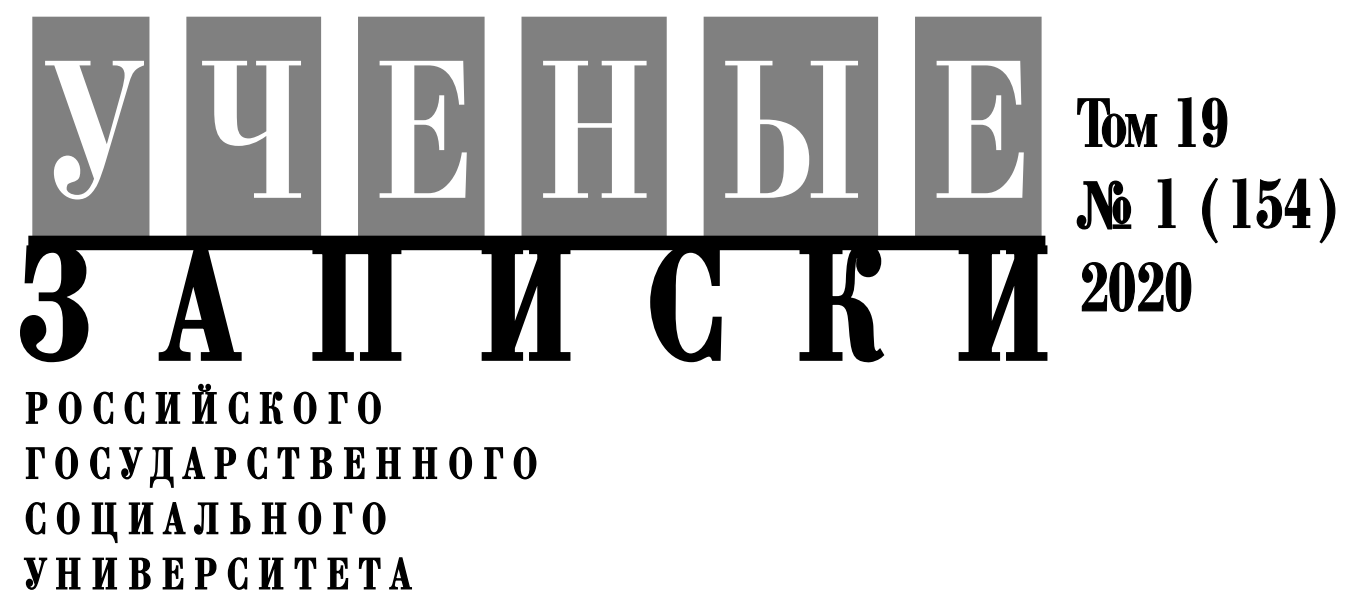




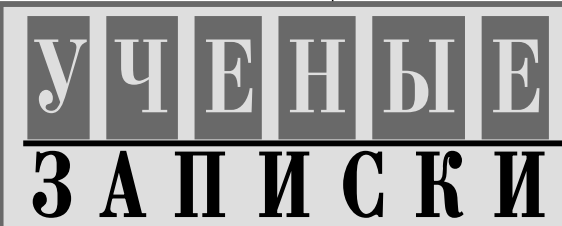

РОССИЙСКОГО ГОСУДАРСТВЕННОГО СОЩИАЛЬНОГО УНИВЕРСИТЕТА Tom 19 № 1 (154) 2020

\section{ISSN 2071-5323}

Решением Президиума ВАК Министерства образования и науки Российской Федерации журнал «Ученые записки РГсу» включен в перечень рецензируемых научных изданий, рекомендуемых для публикации научных работ, отражающих основные научные результаты диссертаций на соискание ученой степени кандидата наук и на соискание ученой степени доктора наук

DOI: 10.17922/2071-5323-2020-19-1 Журнал включен в систему РИНЦ и доступен на сайте: www.elibrary.ru

\section{ГЛАВНЫЙ РЕДАКТОР}

Петрова Е.A.

\section{ЗАМЕСТИТЕЛЬ ГЛАВНОГО РЕДАКТОРА}

Кисляков П.А.

\section{РЕДАКЦИОННАЯ КОЛЛЕГИЯ}

Ануфриева Н.И.

Басимов М.М.

Володарская E.A.

Дженис Прохазка (США, Кингстон)

Карпов В.Ю.

Кудинов С.И.

Луис ван Кессель (Нидерланды, Арнем)

Маджуга А.Г.

Махов A.C.

Миронова 0.И.

Орлова Е.А.

Патриция Вацлавик (Бразилия,

Рестинга-Сека)

Сизикова В.В.

Степанова О.Н.

Третьякова Н.В.

Умберто Солимене (Италия, Милан)

Цветкова Л.А.

Цветкова Н.A.

Шмелева Е.A.

Янчук В.A. (Республика Беларусь, Минск)
М.М. Басимов

M.M. Basimov

Психологическая природа причин неучастия молодежи в выборах ............ 5 Psychological Nature of the Reasons for Non-Participation of Youth in Elections . . . . . . . 5

\section{B.Г. Панушкин}

\section{V.G. Panushkin}

Социоматический анализ как инструмент оценки мотивационной характеристики индекса счастья стран мира . . . . . . . . . . . . . 17 Sociomatrix Analysis As a Researching Tool of the Motivational Characteristics of the Happiness Index of World States. .

\section{Н.В. Белякова, Д.Р. Хасанова}

N.V. Belyakova, D.R. Khasanova

Механизмы формирования

социального интеллекта в подростковом

возрасте . . . . . . . . . . . . . . . . . . . . . .28

The Mechanisms of Formation

of Social Intelligence in Adolescence . . . . . . . . . 28

\section{Е.А. Петрова, М.А. Коваленко, М.С. Сисошвили}

E.A. Petrova, M.A. Kovalenko, M.S. Sisoshvili

Психологическая наблюдательность

в деятельности профайлера . . . . . . . . . . . . . . .37

Psychological Observation

in Profiler Activity. . . . . . . . . . . . . . . . . . . . . 37

\section{О.Б. Полякова}

\section{O.B. Polyakova}

Специфика управленческого потенциала психологов с профессиональными деформациями .......................45

The Specifics of the Managerial Potential of Psychologists with Professional Deformations ......................45

\section{В.Ф. Соколова, Н.А. Цветкова}

\section{V.F. Sokolova, N.A. Tsvetkova}

Сравнительный анализ

социально-психологических характеристик

работающих людей среднего

и пожилого возрастов . . . . . . . . . . . . . . . 555

Comparative Analysis of Socio-Psychological

Characteristics of Middle-Aged

and Elderly Working People . . . . . . . . . . . . . . . .55 
Е.А. Петрова, А.Б. Горячева

E.A. Petrova, A.B. Goryacheva

Сравнительный анализ субъективного

благополучия студентов с разной

академической успеваемостью в зависимости

от ступени обучения . . . . . . . . . . . . . . .66

Comparative Analysis of the Subjective

Well-Being of Students with Different

Academic Achievements in the Dependence

of the Level of Study . . . . . . . . . . . . . . . . . 66

\section{B.Н. Феофанов}

\section{V.N. Feofanov}

Особенности личности специалиста,

работающего с детьми с расстройствами

аутистического спектра (часть 2) . . . . . . . . . . .75

Personality Features of a Specialist Working

with Children with Autism Spectrum Disorders

(Part 2) ...........................75

\section{Н.А. Цветкова, К.Е. Лагвилава}

N.A. Tsvetkova, K.E. Lagvilava

Опыт повышения эффективности женских групп

саморазвития ....................86

Experience in Improving the Effectiveness

of Women's Self-Development Groups . . . . . . . . . . . .86

\section{Е.А. Петрова, К.С. Хожеева \\ E.A. Petrova, K.S. Khozheeva}

Социально-психологические особенности лиц

с нарушениями пищевого поведения . . . . . . . .996

Socio-Psychological Characteristics of People

with Eating Disorders . . . . . . . . . . . . . . . .96

\section{ОБРАЗОВАНИЕ И ПЕДАГОГИКА}

\section{Н.И. Ануфриева \\ N.I. Anufrieva}

Современные методы постановки голоса

в процессе обучения педагогов-музыкантов . . . . .106

Modern Methods of Voice Statement

in the Process of Teaching Teachers-Musicians. . . . . . 106

\section{М.В. Переверзева, В.А. Овсянникова}

M.V. Pereverzeva, V.A. Ovsyannikova

Формирование концертмейстерского мастерства

пианиста в процессе работы с академическими

певцами над камерными сочинениями:

сотворчество и равноправие артистов . . . . . . .114

Formation of Concert Skill of the Pianist

in the Process of Working with Academic Singers

on Chamber Works: Creation and Equality of Artists . . . 114

\section{OTВETСТВЕННЫЙ СЕКРЕТАРЬ}

Вишнякова В.A.

\section{НАД НОМЕРОМ РАБОТАЛИ}

Эксперт I категории

H.E. Папкова

Главный редактор отдела оперативной полиграфии

Н.В. Багрова

Корректор

М.А. Панкратов

Технический редактор

\section{T.A. Пробылова}

Компьютерная верстка и художественное оформление

T.A. Пробыловой

Наш адрес: 129226, Москва, ул. В. Пика, дом 4, корп. 1, каб. 312, 315.

Контактный телефон:

8 (495) 255-67-67

(доб. 17-63, 17-71, 17-80).

http://rgsu.net/about/science/

publishing/magazine/

E-mail: editorialofficeRGSU@yandex.ru

Материалы публикуются в авторской редакции. Авторы опубликованных материалов несут ответственность за подбор и точность приведенных фактов, цитат, собственных имен, статистических данных и прочих сведений. Мнение редакции может не совпадать с мнением авторов статей.

Перепечатка материалов и использование их в любой форме, в том числе и в электронных СМИ, возможны только с письменного разрешения редакции.

Возрастное ограничение: $16+$ 


\section{Е.Ю. Иванова, Д.А. Бережной}

\section{E.Yu. Ivanova, D.A. Berezhnoy}

Образная сфера советской эстрадной песни середины XX века

как отражение социокультурных ценностей советского общества . . . . . . . . . . . 122

The Figurative Sphere of the Soviet Variety Song of the Mid-20 th Century

As a Reflection of the Sociocultural Values of Soviet Society . . . . . . . . . . . . . . . . 122

\section{Н.И. Ануфриева, Е.Б. Покивайлова}

\section{N.I. Anufrieva, E.B. Pokivaylova}

Педагогический потенциал музыкальных произведений

для детей композиторов XX века. . . . . . . . . . . . . . . . . . . . . 129

Pedagogical Potential of Musical Works for Children

of the XXth Century Composers . . . . . . . . . . . . . . . . . . . . . . . . . . . . . 129

\section{М.Г. Круглова, Е.И. Григорьева}

M.G. Kruglova, E.I. Grigorieva

Особенности восприятия музыки детьми и их влияние

на жанры детской музыки . . . . . . . . . . . . . . . . . . . . . . . . . . 137

Features of Children's Perception of Music and Their Impact

on Children's Music Genres . . . . . . . . . . . . . . . . . . . . . . . . . . . . . . . . . . . . . . . 137

\section{C.С. Аксенова, М. Габдиев}

S.S. Aksenova, M. Gabdiyev

Специфика методов обучения детей младшего школьного

возраста основам эстрадного вокального искусства . . . . . . . . . . . . . . . . 144

Specific Methods of Teaching Children of Primary School Age

the Basics of Variety Vocal Art . . . . . . . . . . . . . . . . . . . . . . . 144

\section{М.В. Переверзева, М. Габдиев}

\section{M.V. Pereverzeva, M. Gabdiyev}

Специфика развития эмоциональной сферы подростков

на занятиях эстрадным вокалом . . . . . . . . . . . . . . . . . . . . . . . . . . . . . . . 152

Specifics of Development of Teenagers' Emotional Sphere

in Classes with Variety Vocal. . . . . . . . . . . . . . . . . . . . . . . . . . . 152

\section{Е.А. Мелешкина, А.В. Жилина}

\section{E.A. Meleshkina, A.V. Zhilina}

Семантические доминанты русского музыкального авангарда

в курсе музыкально-исторических дисциплин вузов. . . . . . . . . . . . 160

Semantic Dominants of Russian Musical Vanguard in the Course

of Musical and Historical Disciplines of Higher Education Institutions 


\title{
ПСИхо^ОГИЯ
}

\section{М.М. Басимов,}

д-р психол. наук, профессор кафедры психологии труда и специальной психологии, Российский государственный социальный университет, Москва.

M.M. Basimov,

doctor of psychological sciences, professor of the department of labour

psychology and special psychology, Russian State Social University, Moscow.

E-mail: basimov_@mail.ru

\section{Психологическая природа причин неучастия молодежи в выборах ${ }^{1}$}

\author{
Psychological Nature of the Reasons for Non-Participation \\ of Youth in Elections
}

Дата поступления

16.12.2019
Дата препринта

28.02.2020
Дата публикации

30.03.2020

Аннотация: в статье рассматриваются сравнительные психограммы групп респондентов, сформированных на основании высказанных ими причин, по которым они не принимали участия в выборах. Для анализа использовался авторский метод множественного сравнения (обобщенный вариант). В результате исследования были определены экстремальности 89 сравниваемых групп (в рамках задачи множественного сравнения), шесть из которых рассмотрены в предлагаемой статье. Исходя из суммарной выраженности личностных качеств для двух групп высокой экстремальности (те, кто либо не поддерживает саму идею проведения выборов, либо не видит достойных кандидатур), приводится полное описание психограмм. Для следующих за ними по экстремальности трех групп рассматриваются сокращенные психограммы (только ярко выраженные личностные качества). Исходя из описания выделенных групп участников опроса, можно сделать вывод, что причины отказа от участия в выборах во многом определяются психологическим своеобразием респондентов.

Annotation: the article deals with comparative psychograms of groups of respondents formed on the basis of their stated reasons for not participating in the elections. The author's method of multiple comparison (generalized version) was used for the analysis. As a result of the study, the extremes of 89 compared groups were determined (within the framework of the multiple comparison task), six of which are considered in the proposed article. Based on the total expression of personal qualities for two groups of high extremes (those who either do not support the idea of holding elections, or do not see worthy candidates), a full description of psychograms is given. For the three groups that follow them in terms of extremity, abbreviated psychograms (only pronounced personal qualities) are considered. Based on the description of the selected groups of survey participants, we can conclude that the reasons for refusing to participate in elections are largely determined by the psychological originality of the respondents.

${ }^{1}$ Работа выполнена при поддержке РФФИ, проект № 18-011-01071а. 
Ключевые слова: голосование, выборы, сравнительная психограмма, личностные качества, множественное сравнение, сравнительная весомость.

Key words: voting, elections, comparative psychogram, personal qualities, multiple comparison, comparative weightness.

Введение. Политические установки и представления людей являются основными компонентами массового сознания, которые можно использовать для оценки его состояния и господствующих в нем тенденций. Нельзя преуменьшать важность политической культуры и политической социализации молодежи как факторов повышения стабильности общества и, следовательно, его благосостояния. Значимость изучения социально-политического поведения молодежи, ее политических предпочтений и ориентации возрастает в связи с важностью молодежи как субъекта политических изменений в современной России.

Несмотря на интерес к политике, реальное участие молодежи в политических действиях крайне низкое, а политическая и гражданская активность не являются приоритетным интересом молодого поколения [11, с. 57].

Среди форм социальной активности молодежи, направленных на реализацию социально значимых интересов, важное место занимает социально-политическая активность, под которой, согласно Д.В. Ольшанскому, понимается «деятельность социальных групп или индивидов, связанная с формулированием и выражением собственных потребностей и интересов, со стремлением изменить существующий политический или социально-экономический порядок и соответствующие политические институты» [10, с. 21].

На сегодняшний день электоральное поведение было и остается одной из самых малоизученных областей политической социологии. Авторы отмечают, что «большинство молодого поколения России характеризуется низким уровнем доверия к политике и власти, а также высоким процентом политических абсентеистов, что ставит под сомнение легитимность существующей политической системы...» [3].

Анализировать степень пассивности российской молодежи в политической и общественной жизни можно по результатам разовых и периодических опросов фонда «0бщественное мнение» (ФОМ) [9] и Всероссийского центра исследования общественного мнения (ВЦИОМ) [8]. Например, в статье [1] рассмотрены результаты социологического исследования среди студентов Кемерова. Число абсентеистов в молодежной среде составляет около $30 \%$. «0сновными причинами уклонения молодежи от участия в голосовании являются (по степени убывания): безразличие; низкий интерес к политике; недоверие к партиям, кандидатам, их предвыборным обещаниям; фальсификация результатов; неверие в значимость своего голоса». А в статье [7] детерминанты электоральной пассивности молодежи Российской Федерации рассматриваются на примере Республики Башкортостан.

С позиции социологии часто [5] рассматриваются причины и факторы абсентеизма. Выделены мотивы уклонения работающей молодежи от участия в выборах: недоверие к институту выборов, несогласие с принципами формирования региональной политической элиты, отчуждение от власти и собственности. Электоральная активность и политический абсентеизм молодежи [4; 6] оцениваются в рамках причинно-следственной картины социологии и отчасти политической психологии, но при этом своеобразие личности респондентов просто игнорируется. Мы в своих исследованиях рассматриваем большой спектр политических предпочтений, политической активности и участия молодежи в выборах с точки зрения психологии личности, с позиций того, как личностная типология влияет на отношение к политике, политическим силам, а также исследуем включенность в политическую жизнь молодого человека.

Изучение типа личности дает возможность прогнозировать поведение человека, возможные акцентуации, вероятностные расстройства и т.д. Проводя исследования политических предпочтений молодежи, мы исходим из того, что в зависимости от типа личности можно говорить о политических предпочтениях молодого поколения (не отягощенного жизненным опытом), особенностях политического поведения, политической активности и т.д. В рамках 
таких исследований ставится задача построения эмпирической психологической типологии личности представителей молодого поколения в зависимости от их политической активности, политических предпочтений, установок и т.д.

Зная психологические особенности групп, сформированных по политическим предпочтеним, политической активности и т.д., в рамках многочисленных личностных типологий, появляется возможность решать и обратные задачи, когда в зависимости от типа личности респондента можно с той или иной вероятностью отнести к изучаемым группам политической активности и поведения, политическим предпочтениям: общий взгляд на политику, отношения к отдельным партиям и лидерам. Особенно это касается достаточно значительных по численности политически пассивных групп, которые не участвовали в президентских и парламентских выборах, которые считают, что их голос ничего не решает.

Методы. Мы исследовали политические предпочтения молодежи (формирование групп по результатам ответов на вопросы с номинальными ответами) и их личностные особенности по шести методикам.

1. Свойства личности по базисным шкалам MMPI.

2. Социально-психологические особенности личности с помощью 16-факторного личностного опросника Кеттелла.

3. «Типы личности» и «Вероятностные расстройства» с помощью методики Дж. Олдхема и Л. Морриса.

4. Представления субъекта о себе с помощью методики Т. Лири «0просник диагностики межличностных отношений».

5. Личностные факторы по методике «Пятифакторный личностный опросник» Р. МакКрея, П. Коста.

6. Личностные факторы темперамента и характера по методике «0просник Шмишека».

В эмпирических данных социологического исследования часто присутствуют одновременно два типа переменных: номинальные и интервальные. Это позволяет ставить задачи изучения локальных эмпирических классификаций (типологий). Номинальные переменные можно рассматривать как внешние характеристики (критерии классификации), а интарвальные как внутренние параметры изучаемых классов. Это дает новые возможности в описании результатов опроса, когда данные анализируются через множественное сравнение. Авторский метод [13], решая такие задачи, изучает богатство различий между классами, сформированными по результатам ответов на вопросы (один или несколько) с номинальными ответами, на основе набора интервальных параметров, описывающих те же объекты.

Процедура авторского метода множественного сравнения [12] применительно к социологическим исследованиям подробно (с необходимыми обоснованиями и примерами) рассмотрена в монографии [2].

Локальные эмпирические классификации позволяют рассматривать внутреннюю структуру выделенных подмножеств данных исследования, которая показывает насколько неоднородна совокупность ответов на вопросы анкеты, представленные интервальными переменными, и как эту неоднородность высвечивают и усиливают внешние факторы, представленные номинальными переменными, придавая ей определенную типологическую структуру. Используемый в описываемом исследовании метод ранее применялся в разнообразных по содержанию социологических и психологических исследованиях.

Результаты. В рамках исследования политических предпочтений молодежи и их связи с личностными особенностями респондентов была решена (наряду с многими другими) задача множественного сравнения.

0бработка данных (120 респондентов) проводилась с использованием авторского метода множественного сравнения, в рамках которого сравнивались выделенные группы (всего 89) по номинальным ответам на вопросы анкеты. В расчет для сравнения групп по политическим предпочтениям (всего 63) были включены дополнительно 26 групп по отношению 
к «гражданскому браку». В результате расчета было выявлено, что политические предпочтения значительно сильнее определяются психологическими личностными характеристиками, чем отношения молодежи к «гражданскому браку».

В рамках предлагаемой статьи рассмотрим результаты по шести номинальным группам респондентов, сформированным по причинам неучастия респондентов в выборах. Эти группы определяли результаты ответов на следующий вопрос социологической анкеты.

Назовите, пожалуйста, основную причину, по которой Вы не участвовали в выборах?

G11-01. Уверен(а), что мой голос ничего не решит.

G11-02. Не вижу достойных кандидатур.

G11-03. Выборы ни на что не влияют.

G11-04. Не поддерживаю саму идею проведения выборов.

G11-05. Не верю, что выборы пройдут честно.

G11-06. Ваш вариант.

В результате были выделены шесть невырожденных групп, которые участвовали в общей задаче множественного сравнения.

Но вначале рассмотрим экстремальности (сумма абсолютных значений сравнительных весомостей показателей в рамках группы) групп, отобранных для дальнейшего описания (табл. 1). Группы можно разделить на три подмножества. Первое подмножество (две группы) - группы высокой экстремальности. Для этих двух групп приводятся полные психограммы. Второе подмножество (три группы) - группы средней экстремальности. Для этих трех групп рассматриваются сокращенные психограммы, в которых указываются только ярко выраженные личностные качества (в рамках рассматриваемой задачи - это личностные качества со сравнительной весомостью, превышающей 2000). Оставшаяся группа, в которой не выявлено отдельных ярко выраженных качеств (модуль сравнительной весомости больше 2000), достаточно усредненная в рамках совокупности 89 групп, не описывается ниже в психологическом плане.

Таблица 1

Экстремальности 6 из 89 групп по номинальным ответам

\begin{tabular}{|c|c|c|}
\hline $\begin{array}{c}\text { Место в упорядоченном ряде } \\
\text { 63(89) групп }\end{array}$ & Группа & Экстремальность \\
\hline $6(6)$ & G11-04 & 46853 \\
\hline $7(7)$ & G11-02 & 46051 \\
\hline $35(40)$ & G11-03 & 20882 \\
\hline $43(51)$ & G11-05 & 19964 \\
\hline $45(53)$ & G11-06 & 19415 \\
\hline $48(58)$ & G11-01 & 17507 \\
\hline
\end{tabular}

Перейдем к психологическому описанию шести выделенных групп по причинам неучастия респондентов в выборах. В заголовках групп приводится количество уровней в сравнительной психограмме группы (KOL/ur), минимальное (VES/min) и максимальное (VES/max) значение сравнительной весомости в рамках групп.

\section{Группа по ответу (G11-04) \\ $\mathrm{KOL} / \mathrm{ur}=64 \mathrm{VES} / \mathrm{min}=-6857 \mathrm{VES} / \mathrm{max}=+5101$}

Группа респондентов G11-04, которые не участвовали в выборах, потому что не поддерживают саму идею проведения выборов (5 респондентов), оказалась на шестом месте по совокупной экстремальности личностных качеств. Наибольшая сравнительная весомость среди изучаемых психологических показателей равна +5101 , минимальная сравнительная весомость равна -6857. 
Группа показателей № 4 (Опросник Лири)

\begin{tabular}{|c|c|c|}
\hline 5) (117) & LIR-08 & -2036 \\
\hline 4) (91) & LIR-06 & -2308 \\
\hline 1)(2) & LIR-07 & -6857 \\
\hline
\end{tabular}

В рамках методики Лири в группе отрицательная экстремальность, т.е. что им абсолютно несвойственно, наблюдается по шкале «Дружелюбный тип» со сравнительной весомостью (-6857). Значительно меньше это касается показателей «Зависимый тип», со сравнительной весомостью (-2308), и «Альтруистичный тип», со сравнительной весомостью (-2036).

Группа показателей № 5 (Пятифакторный опросник личности)

\begin{tabular}{|c|c|c|}
\hline 64$)(1615)$ & $25 \mathrm{~F}-03$ & +5101 \\
\hline 63$)(1591)$ & $25 \mathrm{~F}-07$ & +3840 \\
\hline 62$)(1581)$ & $25 \mathrm{~F}-08$ & +3564 \\
\hline
\end{tabular}

Представителей группы, которые не поддерживают саму идею проведения выборов, можно охарактеризовать прежде всего как замкнутых (сравнительная весомость по шкале «0бщительность - замкнутость» равна +5101); в меньшей степени как склонных к соперничеству (сравнительная весомость по шкале «Сотрудничество - соперничество» равна +3840) и подозрительных (сравнительная весомость по шкале «Доверчивость - подозрительность» равна +3564).

Для примера (в виду недостаточности места в рамках статьи) для двух групп наибольшей экстремальности приведем полные распределения структурной части психограммы, в которой представлены показатели пятифакторной модели личности.

Группа показателей № 5 (Пятифакторный опросник личности)

\begin{tabular}{|c|c|c|}
\hline 64$)(1615)$ & $25 \mathrm{~F}-03$ & +5101 \\
\hline 63$)(1591)$ & $25 \mathrm{~F}-07$ & +3840 \\
\hline 62$)(1581)$ & $25 \mathrm{~F}-08$ & +3564 \\
\hline 61$)(1518)$ & $25 \mathrm{~F}-23$ & +1956 \\
\hline 60$)(1465)$ & $25 \mathrm{~F}-09$ & +1359 \\
\hline 59$)(1419)$ & $25 \mathrm{~F}-18$ & +1051 \\
\hline 58$)(1310)$ & $25 \mathrm{~F}-04$ & +643 \\
\hline 55$)(1016)$ & $25 \mathrm{~F}-05$ & +201 \\
\hline 54$)(955)$ & $25 \mathrm{~F}-17$ & +140 \\
\hline 52$)(908)$ & $25 \mathrm{~F}-10$ & +93 \\
\hline 51$)(892)$ & $25 \mathrm{~F}-11$ & +77 \\
\hline 50$)(891)$ & $25 \mathrm{~F}-15$ & +76 \\
\hline 47$)(863)$ & $25 \mathrm{~F}-20$ & +48 \\
\hline 45$)(828)$ & $25 \mathrm{~F}-16$ & +13 \\
\hline 42$)(818)$ & $25 \mathrm{~F}-19$ & +3 \\
\hline 41$)(817)$ & $25 \mathrm{~F}-01$ & +2 \\
\hline 40$)(816)$ & $25 \mathrm{~F}-12$ & +1 \\
\hline 39$)(815)$ & $25 \mathrm{~F}-0225 \mathrm{~F}-06$ & 0 \\
\hline 38$)(814)$ & $25 \mathrm{~F}-2225 \mathrm{~F}-14$ & -1 \\
\hline 36$)(810)$ & $25 \mathrm{~F}-13$ & -5 \\
\hline 33$)(806)$ & $25 \mathrm{~F}-21$ & -9 \\
\hline 11$)(398)$ & $25 \mathrm{~F}-25$ & -564 \\
\hline 10$)(338)$ & $25 \mathrm{~F}-24$ & \\
\hline
\end{tabular}


Группа показателей № 6 (0просник DSM)

2) (11) $\quad$ DSM-08 1

В рамках опросника DSM со знаком минус (сравнительная весомость равна -5661), т.е. что абсолютно несвойственно представителям рассматриваемой группы, можно отметить чувствительный тип с вероятным для этого типа расстройством «Уклонение».

Группа показателей № 7 (Дополнения PSY)

\begin{tabular}{|c|c|c|}
\hline 3) (78) & PSY-02 & -2626 \\
\hline
\end{tabular}

В рамках дополнительных показателей отметим шкалу «Достоверность» опросника MMPI (сравнительная весомость равна -2626).

$$
\begin{gathered}
\text { Группа по ответу (G11-02) } \\
\mathrm{KOL} / \mathrm{ur}=82 \mathrm{VES} / \mathrm{min}=-6898 \mathrm{VES} / \mathrm{max}=+6580
\end{gathered}
$$

Группа респондентов G11-02, которые не принимали участия в выборах по основной причине, потому что не видят достойных кандидатур (12 респондентов), оказалась на седьмом месте по совокупной экстремальности личностных качеств. Наибольшая сравнительная весомость среди изучаемых психологических показателей равна +6580 , минимальная сравнительная весомость равна -6898.

Группа показателей № 1 (0просник MMPI)

\begin{tabular}{|l|l|l|}
\hline 81) (1631) & MMPI-2 & +6394 \\
\hline 80$)(1579)$ & MMPI-3 & +3483 \\
\hline 79$)(1524)$ & MMPI-6 & +2033 \\
\hline
\end{tabular}

Группа респондентов, которые не видят достойных кандидатур, характеризуется, прежде всего, ярко выраженной депрессией (сравнительная весомость равна +6394), в меньшей степени истерией (сравнительная весомость равна +3483) и психастенией (сравнительная весомость равна +2033$)$.

Группа показателей № 2 (Опросник Кеттелла)

\begin{tabular}{|c|c|c|}
\hline 3$)(60)$ & $16 \mathrm{~F}-09$ & -2987 \\
\hline 1$)(1)$ & $16 \mathrm{~F}-06$ & -6898 \\
\hline
\end{tabular}

Представители данной группы характеризуются сильно выраженной подверженностью чувствам (фактор $\mathrm{G}$ ), что определяется значительной отрицательной сравнительной весомостью (-6898) по шкале «Подверженность чувствам - высокая нормативность поведения», а также, но в меньшей степени, доверчивостью (фактор L), что определяется отрицательной сравнительной весомостью (-2987) по шкале «Доверчивость - подозрительность».

Полное распределение рассматриваемой структурной части психограммы приведено ниже.

Группа показателей № 5 (Пятифакторный опросник личности)

\begin{tabular}{|c|c|c|}
\hline 82$)(1632)$ & $25 \mathrm{~F}-12$ & +6580 \\
\hline 78$)(1460)$ & $25 \mathrm{~F}-13$ & +1335 \\
\hline 76$)(1365)$ & $25 \mathrm{~F}-11$ & +802 \\
\hline 73$)(1147)$ & $25 \mathrm{~F}-21$ & +344 \\
\hline 72$)(1104)$ & $25 \mathrm{~F}-15$ & +293 \\
\hline
\end{tabular}




\begin{tabular}{|c|c|c|}
\hline & & Окончание таблицы \\
\hline 68) (993) & $25 \mathrm{~F}-01$ & +178 \\
\hline 66) (967) & $25 \mathrm{~F}-02$ & +152 \\
\hline 62) (928) & $25 \mathrm{~F}-20$ & +113 \\
\hline 58) (855) & $25 \mathrm{~F}-09$ 25F-14 & +40 \\
\hline 56) (848) & $25 \mathrm{~F}-06$ & +33 \\
\hline 55) (840) & $25 \mathrm{~F}-08$ & +25 \\
\hline 54) (839) & $25 \mathrm{~F}-07$ & +24 \\
\hline 53) (837) & $25 \mathrm{~F}-04$ & +22 \\
\hline 49) (826) & $25 \mathrm{~F}-2225 \mathrm{~F}-24$ & +11 \\
\hline 45) (814) & $25 \mathrm{~F}-16$ & -1 \\
\hline 44) (811) & $25 \mathrm{~F}-05$ & -4 \\
\hline 42) (805) & $25 \mathrm{~F}-23$ & -10 \\
\hline 39) (799) & $25 \mathrm{~F}-03$ & -16 \\
\hline 34) (784) & $25 \mathrm{~F}-18$ & -31 \\
\hline 31) (774) & $25 \mathrm{~F}-25$ & -41 \\
\hline 24) (715) & $25 \mathrm{~F}-10$ & -100 \\
\hline 16) (604) & $25 \mathrm{~F}-17$ & -211 \\
\hline 14) (543) & $25 \mathrm{~F}-19$ & -273 \\
\hline
\end{tabular}

Представителей группы, которые не видят достойных кандидатур на выборах, можно охарактеризовать как крайне ненастойчивых (сравнительная весомость по шкале «Настойчивость - отсутствие настойчивости» равна +6580$)$.

Группа показателей № 6 (Опросник DSM)
2) (49)
DSM-10
$-3328$

В рамках опросника DSM со знаком минус, т.е. что абсолютно несвойственно представителям рассматриваемой группы, можно отметить добросовестный тип с вероятным для этого типа расстройством «Навязчиво-принудительный» (сравнительная весомость равна $-3328)$.

\section{Группа по ответу (G11-03) \\ $\mathrm{KOL} / \mathrm{ur}=79 \mathrm{VES} / \mathrm{min}=-3760 \mathrm{VES} / \mathrm{max}=+1081$}

Группа G11-03 респондентов, которые в качестве причины, по которой они не участвовали в выборах, заявляют, что выборы ни на что не влияют (13 респондентов), оказалась на 35 месте по совокупной экстремальности личностных качеств. Наибольшая сравнительная весомость среди изучаемых психологических показателей равна +1081 , минимальная сравнительная весомость равна -3760 .

Группа показателей № 5 (пятифакторный опросник личности)

\begin{tabular}{|c|c|c|}
\hline 3) (116) & $25 \mathrm{~F}-12$ & -2060 \\
\hline 2) (99) & $25 \mathrm{~F}-15$ & -2219 \\
\hline 1) (39) & $25 \mathrm{~F}-19$ & -3760 \\
\hline
\end{tabular}

Респондентов, которые считают, что выборы ни на что не влияют, можно охарактеризовать как самокритичных (сравнительная весомость по шкале «Самокритика - самодостаточность» равна -3760); предусмотрительных (сравнительная весомость по шкале «Пред- 
усмотрительность - беспечность» равна -2219); настойчивых (сравнительная весомость по шкале «Настойчивость - отсутствие настойчивости» равна -2060).

$$
\begin{gathered}
\text { Группа по ответу (G11-06) } \\
\mathrm{KOL} / \mathrm{ur}=80 \mathrm{VES} / \mathrm{min}=-2692 \mathrm{VES} / \mathrm{max}=+2033
\end{gathered}
$$

Группа G11-06 респондентов, которые в качестве причины, по которой они не участвовали в выборах, предлагают свои нестандартны варианты (13 респондентов), оказалась на 45 месте по совокупной экстремальности личностных качеств. Наибольшая сравнительная весомость среди изучаемых психологических показателей равна +2033 , минимальная сравнительная весомость равна -2692 .

Группа показателей № 4 (Опросник Лири)

\begin{tabular}{|c|c|c|}
\hline 2) (95) & LIR-06 & -2265 \\
\hline 1) (76) & LIR-05 & -2692 \\
\hline
\end{tabular}

В рамках методики Лири в группе отрицательная экстремальность наблюдается по шкалам «Подчиняемый тип» со сравнительной весомостью (-2692) и «Зависимый тип» со сравнительной весомостью (-2265).

Группа показателей № 5 (Пятифакторный опросник личности)

\begin{tabular}{|l|l|l|}
\hline 80$)(1524)$ & $25 \mathrm{~F}-05$ & +2033 \\
\hline
\end{tabular}

Респондентов рассматриваемой группы можно охарактеризовать как избегающих внимания (сравнительная весомость по шкале «Привлечение внимания - избегание внимания» равна +2033).

$$
\begin{gathered}
\text { Группа по ответу (G11-01) } \\
\mathrm{KOL} / \mathrm{ur}=78 \mathrm{VES} / \mathrm{min}=-2091 \mathrm{VES} / \mathrm{max}=+586
\end{gathered}
$$

Группа G11-01 респондентов, которые основной причиной своего неучастия в выборах считают уверенность, что их голос ничего не решит (22 респондента), оказалась на 48 месте по совокупной экстремальности личностных качеств. Наибольшая сравнительная весомость среди изучаемых психологических показателей равна +586 , минимальная сравнительная весомость равна -2091.

Группа показателей № 5 (Пятифакторный опросник личности)

\begin{tabular}{|l|l|l|}
\hline 1) (112) & 25F-10 & -2091 \\
\hline
\end{tabular}

Респондентов рассматриваемой группы можно охарактеризовать как уважающих других (сравнительная весомость по шкале «Уважение других - самоуважение» равна -2091).

$$
\begin{gathered}
\text { Группа по ответу (G11-05) } \\
\mathrm{KOL} / \mathrm{ur}=83 \mathrm{VES} / \mathrm{min}=-1211 \mathrm{VES} / \mathrm{max}=+1106
\end{gathered}
$$

Группа G11-05 респондентов, которые не участвовали в выборах по той причине, что не верят, что выборы пройдут честно (30 респондентов), оказалась на 43 месте по совокупной экстремальности личностных качеств. Наибольшая сравнительная весомость среди изучаемых психологических показателей равна +1106 , минимальная сравнительная весомость равна -1211.

В этой группе не нашлось личностных качеств, достойных обсуждения (сравнительная весомость по модулю превышает 2000). 
Обсуждение. По результатам представленной информации можно говорить, что причины, по которым респонденты не участвовали в выборах, во многом определяются их психологическим своеобразием. Шесть сравниваемых групп по результатам ответа на вопрос анкеты «Назовите, пожалуйста, основную причину, по которой Вы не участвовали в выборах?» по экстремальности (степени выраженности личностных качеств) разделились на три подмножества.

I. Группы высокой экстремальности, респонденты которых:

1) не поддерживают саму идею проведения выборов;

2) не видят достойных кандидатур.

II. Группы средней экстремальности, респонденты которых:

1) считают, что выборы ни на что не влияют;

2) предлагают свой вариант ответа;

3) уверены, что их голос ничего не решит.

III. Группа низкой экстремальности, представленная респондентами, которые не верят, что выборы пройдут честно.

Заключение. В последние годы молодежь всё больше волнуется о своей карьере, своем финансовом состоянии. Политикой молодые люди чаще интересуются для того, чтобы знать, чем и как государство может им в этом помочь. Одним из факторов аполитичности выступает низкая политическая культура молодежи. Поэтому молодое поколение не может в полной мере участвовать в политических событиях страны - даже парламентские и президентские выборы игнорируются большинством молодых респондентов.

На сегодняшний день большое значение имеет проблема создания новой ценностной системы: ценности советского времени были разрушены, а новые, отвечающие современным реалиям, сформированы не были. Молодые россияне теряют чувство национальной принадлежности и не могут найти свое место в новых условиях. Молодежь часто считает, что ее мнение, а точнее, голос, ни на что не влияет. И данную точку зрения в их мировоззрении подтверждает несменяемость политической элиты в последние десятилетия.

Всё это отразилось в рассмотрении как отдельной интерпретационной задачи проблемы психологического компонента политической пассивности молодежи и, прежде всего, их неучастия в выборах, что подтвердили более половины из опрошенных респондентов. В результате своеобразность каждой группы по указанной ими причине неучастия в выборах была описана через психологический портрет в сравнительном аспекте по шкалам шести личностных методик.

Для построения сравнительных психограмм были использованы авторские методы множественного сравнения (обобщенный вариант) психологических параметров для сформированных групп по номинальным ответам респондентов на вопросы социологической анкеты.

Валидность методов подтверждается многолетними исследованиями в рамках изучения нелинейной природы применительно к общественным наукам и наукам о человеке. Несмотря на то что нелинейная природа психологических и социологических данных для большинства исследователей актуальной не является, тема эта важна и актуальна, а разговор о традиционных ошибках, возникающих благодаря «новым» правилам статистики, когда благодаря невидимым для подавляющего большинства исследователей грубым ошибкам получаются «нужные» результаты, поднимался автором и его единомышленниками на социологических (ESA, ISA) [14, р. 1346; 22, р. 563] и психологических (ECP, IPC) [15, р. 789; 16, p. $903 ; 17$, p. $1065-1066 ; 18$, p. 788; 19, p. 790; 20, p. 774; 21, p. 776; 23, p. 783; 24, p. 785; 25, p. 784; 26, p. 1100; 27, p. 779; 28, p. 778] конгрессах (всего 58 презентаций), а также в многочисленных статьях.

\section{Список литературы}

1. Аршинова Е.В., Билан М.А., Горбатова М.М., Рассохина И.Ю. Ценностные аспекты электорального поведения студенческой молодежи // Профессиональное образование 
в России и за рубежом. 2019. № 1 (33). С. 119-127. URL: https://elibrary.ru/full_text. asp?id=37273456.

2. Басимов М.М. Множественное сравнение в социологических исследованиях: монография. Курган: Курган. гос. ун-т, 2012. 224 с. URL: http://dspace.kgsu.ru/xmlui/ handle/123456789/3724/browse?value=Басимов+Михаил+Михайлович\&type =author.

3. Бетехтина А.В., Олухов Н.В. Электоральное поведение молодежи: почему молодежь не ходит на выборы? // Вопросы управления. 2012. № 20. URL: http://vestnik.uapa.ru/ru/ issue/2012/03/2/.

4. Ежов Д.А. Актуальные тенденции и факторы электоральной активности российской молодежи // Азимут научных исследований: экономика и управление. Т. 7. 2018. № 3 (24). С. 356-358.

5. Зинченко Г.П. От чего зависит электоральная активность молодежи // Северо-Кавказский юридический вестник. 2015. № 3. С. 134-137.

6. Зуляр Р.Ю., Григорьев Д.А. Политический абсентеизм молодежи: протестное голосование как фактор преодоления (на примере выборов губернатора Иркутской области 2015 г.) // Известия Иркутского государственного университета. Серия: Политология. Религиоведение. 2016.

7. Каримов Р.А. Детерминанты электоральной пассивности молодежи РФ (на примере Республики Башкортостан) // Ученые записки Казанского университета. Серия: Гуманитарные науки. Т. 156. 2014. № 6. 2014. С. 238-245.

8. Официальный сайт Всероссийского центра исследования общественного мнения (ВцИOM). URL: http://wciom.ru/.

9. Официальный сайт фонда «Общественное мнение» (ФOM). URL: http://fom.ru/.

10. Ольшанский Д.В. Политико-психологический словарь. М., 2002.

11. Чуев С.В., Тимохович А.Н. Гришаева С.А. Политические ценности российской молодежи: материалы исследования // Власть. 2017. № 11.

12. Basimov M. Mathematical methods in psychological research (Nontraditional methods): monograph. Germany, Saarbrucken: LAP LAMBERT Academic Publishing, 2011. 185 p.

13. Basimov M. Methods of multiple comparison in psychological research: Monograph. Kurgan: Kurgan State University, 2008. 101 p.

14. Basimova P. Approval of a marriage between representatives of different nationalities in nonlinear sociology // The 11th Conference of the European Sociological Association (Torino, 28-31 August 2013): Abstract Book. Torino, 2013.

15. Basimova P. Commitment to Principles in Pedagogic Activity (non-linear aspect) // International Journal of Psychology. Vol. 51. 2016. Sup. S1.

16. Basimova P. Competitiveness as the reason Impulsiveness in non-linear psychology (FiveFactor Personality Model) // International Journal of Psychology. Vol. 51. 2016. Sup. S1.

17. Basimova P. Regression psychological defence as cause and effect of interpersonal relationships in youth environment // XVI European Congress of Psychology (ECP 2019) (2-5 July, 2019, Lomonosov Moscow State University, Moscow): Book of Abstracts. M.: Moscow University Press, 2019. URL: https://ecp2019.ru/ru/programme/thematic/.

18. Basimova P., Basimova 0. Education fee as the reason of typological characteristics of the student // The $14^{\text {th }}$ European Congress of Psychology (Milan, Italy 7-10 july 2015): AbstractBook, Posters. Milan, 2015.

19. Basimova P., Basimova 0. Psychological nature of social motives of university admission // The $14^{\text {th }}$ European Congress of Psychology (Milan, Italy 7-10 july 2015): AbstractBook, Posters. Milan, 2015.

20. Dostovalov S. Stress as an object of non-linear psychology // The $14^{\text {th }}$ European Congress of Psychology (Milan, Italy 7-10 july 2015): AbstractBook, Posters. Milan, 2015.

21. Dostovalov S. Stress as the reason of the self-realization and Interpersonal trust // The $14^{\text {th }}$ European Congress of Psychology (Milan, Italy 7-10 july 2015): AbstractBook, Posters. Milan, 2015.

22. Kornienko V. Printed publications as a source of information about the policy // The 13th Conference of the European Sociological Association (Athens, Greece, 29 August - 1 Sepember 2017): AbstractBook. Athens, 2017. URL: https://www.europeansociology.org/publications/ esa-conference-abstract-books.

23. Nikolaeva I. Non-linear relation of conviction in favour of the world and communicative tolerance // The $14^{\text {th }}$ European Congress of Psychology (Milan, Italy 7-10 july 2015): AbstractBook, Posters. Milan, 2015. 
24. Nikolaeva I. Non-linear relation of durability and subjective remoteness from "Worst others" // The $14^{\text {th }}$ European Congress of Psychology (Milan, Italy 7-10 july 2015): AbstractBook, Posters. Milan, 2015.

25. Nikolaeva I. Value characteristic "I" as object of non-linear psychology // The $14^{\text {th }}$ European Congress of Psychology (Milan, Italy 7-10 july 2015): AbstractBook, Posters. Milan, 2015.

26. Padurina E. Positive feelings in the family and their expression among mothers and fathers // XVI European Congress of Psychology (ECP 2019) (2-5 July, 2019, Lomonosov Moscow State University, Moscow): Book of Abstracts. M.: Moscow University Press, 2019. URL: https:// ecp2019.ru/ru/programme/ thematic/.

27. Padurina E. Positive feelings to the spouse as to the parent as an object of non-linear psychology // The $14^{\text {th }}$ European Congress of Psychology (Milan, Italy 7-10 july 2015): AbstractBook, Posters. Milan, 2015.

28. Padurina E. Understanding of the reasons of a condition of the child as an object of nonlinear psychology // The $14^{\text {th }}$ European Congress of Psychology (Milan, Italy 7-10 july 2015): AbstractBook, Posters. Milan, 2015.

\section{References}

1. Arshinova E.V., Bilan M.A., Gorbatova M.M., Rassokhina I.Yu. Cennostnye aspekty elektoral'nogo povedeniya studencheskoj molodezhi // Professional'noe obrazovanie $v$ Rossii i za rubezhom. 2019. № 1 (33). S. 119-127. URL: https://elibrary.ru/full_text.asp?id=37273456.

2. Basimov M.M. Mnozhestvennoe sravnenie $v$ sociologicheskikh issledovaniyakh: monografiya. Kurgan: Kurgan. gos. un-t, 2012. 224 s. URL: http://dspace.kgsu.ru/xmlui/ handle/123456789/3724/browse?value=Basimov+Mikhail+Mikhajlovich\&type =author.

3. Betekhtina A.V., Olukhov N.V. Elektoral'noe povedenie molodezhi: pochemu molodezh' ne khodit na vybory? // Voprosy upravleniya. 2012. № 20. URL: http://vestnik.uapa.ru/ru/ issue/2012/03/2/.

4. Ezhov D.A. Aktual'nye tendencii i faktory elektoral'noj aktivnosti rossijskoj molodezhi // Azimut nauchnykh issledovanij: ekonomika i upravlenie. T. 7. 2018. № 3 (24). S. 356-358.

5. Zinchenko G.P. Ot chego zavisit elektoral'naya aktivnost' molodezhi // Severo-Kavkazskij yuridicheskij vestnik. 2015. № 3. S. 134-137.

6. Zulyar R.Yu., Grigor'ev D.A. Politicheskij absenteizm molodezhi: protestnoe golosovanie kak faktor preodoleniya (na primere vyborov gubernatora Irkutskoj oblasti 2015 g.) // Izvestiya Irkutskogo gosudarstvennogo universiteta. Seriya: Politologiya. Religiovedenie. 2016.

7. Karimov R.A. Determinanty elektoral'noj passivnosti molodezhi RF (na primere respubliki Bashkortostan) // Uchenye zapiski Kazanskogo universiteta. Seriya: Gumanitarnye nauki. T. 156. 2014. № 6. 2014. S. 238-245.

8. Oficial'nyj sajt Vserossijskogo centra issledovaniya obshchestvennogo mneniya (VCIOM). URL: http://wciom.ru/.

9. Oficial'nyj sajt fonda «Obshchestvennoe mnenie» (FOM). URL: http://fom.ru/.

10. Ol'shanskij D.V. Politiko-psikhologicheskij slovar'. M., 2002.

11. Chuev S.V., Timokhovich A.N. Grishaeva S.A. Politicheskie cennosti rossijskoj molodezhi: materialy issledovaniya // Vlast'. 2017. № 11.

12. Basimov M. Mathematical methods in psychological research (Nontraditional methods): monograph. Germany, Saarbrucken: LAP LAMBERT Academic Publishing, 2011. 185 p.

13. Basimov M. Methods of multiple comparison in psychological research: monograph. Kurgan: Kurgan State University, 2008. 101 p.

14. Basimova P. Approval of a marriage between representatives of different nationalities in nonlinear sociology // The 11th Conference of the European Sociological Association (Torino, 28-31 August 2013): Abstract Book. Torino, 2013.

15. Basimova P. Commitment to Principles in Pedagogic Activity (non-linear aspect) // International Journal of Psychology. Vol. 51. 2016. Sup. S1.

16. Basimova P. Competitiveness as the reason Impulsiveness in non-linear psychology (FiveFactor Personality Model) // International Journal of Psychology. Vol. 51. 2016. Sup. S1.

17. Basimova P. Regression psychological defence as cause and effect of interpersonal relationships in youth environment // XVI European Congress of Psychology (ECP 2019) (2-5 July, 2019, Lomonosov Moscow State University, Moscow): Book of Abstracts. M.: Moscow University Press, 2019. URL: https://ecp2019.ru/ru/programme/thematic/. 
18. Basimova P., Basimova 0. Education fee as the reason of typological characteristics of the student // The 14th European Congress of Psychology (Milan, Italy 7-10 july 2015): AbstractBook, Posters. Milan, 2015.

19. Basimova P., Basimova 0. Psychological nature of social motives of university admission // The 14th European Congress of Psychology (Milan, Italy 7-10 july 2015): AbstractBook, Posters. Milan, 2015.

20. Dostovalov S. Stress as an object of non-linear psychology // The 14th European Congress of Psychology (Milan, Italy 7-10 july 2015): AbstractBook, Posters. Milan, 2015.

21. Dostovalov S. Stress as the reason of the self-realization and Interpersonal trust // The 14th European Congress of Psychology (Milan, Italy 7-10 july 2015): AbstractBook, Posters. Milan, 2015.

22. Kornienko V. Printed publications as a source of information about the policy // The 13th Conference of the European Sociological Association (Athens, Greece, 29 August - 1 Sepember 2017). AbstractBook: Athens, 2017. URL: https://www.europeansociology.org/publications/ esa-conference-abstract-books.

23. Nikolaeva I. Non-linear relation of conviction in favour of the world and communicative tolerance // The 14th European Congress of Psychology (Milan, Italy 7-10 july 2015). AbstractBook, Posters: Milan, 2015.

24. Nikolaeva I. Non-linear relation of durability and subjective remoteness from "Worst others" // The 14th European Congress of Psychology (Milan, Italy 7-10 july 2015): AbstractBook, Posters. Milan, 2015.

25. Nikolaeva I. Value characteristic "I" as object of non-linear psychology // The 14th European Congress of Psychology (Milan, Italy 7-10 july 2015): AbstractBook, Posters. Milan, 2015.

26. Padurina E. Positive feelings in the family and their expression among mothers and fathers // XVI European Congress of Psychology (ECP 2019) (2-5 July, 2019, Lomonosov Moscow State University, Moscow): Book of Abstracts. M.: Moscow University Press, 2019. URL: https:// ecp2019.ru/ru/programme/ thematic/.

27. Padurina E. Positive feelings to the spouse as to the parent as an object of non-linear psychology // The 14th European Congress of Psychology (Milan, Italy 7-10 july 2015): AbstractBook, Posters. Milan, 2015.

28. Padurina E. Understanding of the reasons of a condition of the child as an object of nonlinear psychology // The 14th European Congress of Psychology (Milan, Italy 7-10 july 2015): AbstractBook, Posters. Milan, 2015.

\section{Библиографическое описание статьи / Reference to article}

Басимов М.М. Психологическая природа причин неучастия молодежи в выборах // Ученые записки Российского государственного социального университета. Т. 19. 2020. № 1 (154). C. 5-16. DOI: 10.17922/2071-5323-2020-19-1-5-16 (Библиографическое описание согласно российским стандартам).

Basimov M.M. Psikhologicheskaya priroda prichin neuchastiya molodezhi v vyborakh // Uchenye zapiski Rossijskogo gosudarstvennogo social'nogo universiteta. T. 19. 2020. № 1 (154). S. 5-16. DOI: 10.17922/2071-5323-2020-19-1-5-16 (Reference in Roman script). Basimov, M.M. (2020) Psychological Nature of the Reasons for Non-Participation of Youth in Elections, Scientific Notes of Russian State Social University. Vol. 19. No. 1 (154). P. 5-16. DOI: 10.17922/2071-5323-2020-19-1-5-16 (International bibliographic description). 


\title{
В.Г. Панушкин,
}

психолог, директор Центра социальных матричных технологий «Социома»,

Москва.

V.G. Panushkin,

psychologist, director of the Center for social matrix technologies "Socioma",

Moscow.

E-mail: sociomas@yandex.ru

\section{Социоматический анализ как инструмент оценки мотивационной характеристики индекса счастья стран мира}

\author{
Sociomatrix Analysis As a Researching Tool of the Motivational \\ Characteristics of the Happiness Index of World States
}

Дата поступления

09.12 .2019
Дата препринта

28.02.2020
Дата публикации

30.03.2020

Аннотация: переживание состояния счастья как сильного положительного эмоционального фона поведения человека всегда было активным мотивирующим источником движения к совершенству и достижения новых, более высоких результатов. Летом 2011 года Генеральная Ассамблея Организации Объединенных Наций призвала руководителей всех государств ориентироваться на уровень счастья своего населения для достижения лучших результатов своего развития. Начиная с 2012 года под эгидой ООН Институт Земли в сотрудничестве с Институтом Гэллапа стали проводить ежегодные исследования эмоционального состояния населения стран мира, публикуя свои результаты в ежегодных отчетах о текущем мировом индексе счастья (World Happiness Report). В данной статье показано, что определенное влияние на место страны в рейтинге индекса счастья оказывает текущий эмоционально-смысловой фон, формируемый местными СМИ, отражающими реальную жизнь населения. Исследование проводилось средствами социоматического анализа.

Annotation: the experience of happiness as a strong positive emotional background of human behavior has always been an active motivating source of movement to perfection and achieving new, higher results. In the summer of 2011, the United Nations General Assembly called on the leaders of all States to focus on the happiness of their populations in order to achieve better results in their development. Since 2012, under the auspices of the UN, the Earth Institute in cooperation with the Gallup Institute began to conduct annual studies of the emotional state of the world's population, publishing its results in the annual reports on the current world Happiness index (World Happiness Report). This article shows that the current emotional and semantic background formed by the local media reflecting the real life of the population has a certain influence on the place of the country in the ranking of the happiness index. The study was completed using sociomatrix analyse.

Ключевые слова: Социома, социальная матрица, социоматический анализ, индекс счастья.

Key words: Socioma, social matrix, sociomatrix analysis, happiness index.

Введение. Счастье - одна из тех категорий, объективное измерение которой всегда считалось чем-то неуловимым. Арабский священник VII века Абдулла ибн Салям Бахама считал, что «счастье - это постоянное чувство блаженства и уверенности и спокойствия» [1]. Но такому пониманию всегда сопутствовало активно-действенное представление о счастье. 
К примеру, если вдуматься в состав этого слова на русском языке, то станет понятным, что быть «с частью», обладать долей чего-то большого или быть причастным к чему-то большому значительно лучше, чем быть без него. Ф.М. Достоевский, говоря об этом чувстве в романе «Идиот», писал: «Спросите, спросите их только, как они все, сплошь до единого, понимают, в чем счастье? 0, будьте уверены, что Колумб был счастлив не тогда, когда открыл Америку, а когда открывал ее; будьте уверены, что самый высокий момент его счастья был, может быть, ровно за три дня до открытия Нового Света, когда бунтующий экипаж в отчаянии чуть не поворотил корабля в Европу, назад! Не в Новом Свете тут дело, хотя бы он провалился. Колумб помер, почти не видав его и, в сущности, не зная, что он открыл. Дело в жизни, в одной жизни, - в открывании ее, беспрерывном и вечном, а совсем не в открытии!» [3]. Наслаждение переполняющим ярким эмоциональным предчувствием чего-то грандиозного и неповторимого, но вполне достижимого вот прямо сейчас, лишь стоит протянуть руку, делает сильный акцент на собственном действии. Семантика слов, со временем трансформируясь и приобретая новые эмоциональные окраски, сохраняет свою смысловую неизменность на социальной матрице с древних времен. Очевидный сильный мотивирующий посыл этого чувства не мог не выразиться в том, чтобы именно чувство счастья стало для многих стран мира одним из главных ориентиров собственного развития.

Летом 2011 года Генеральная Ассамблея 00H [2] приняла резолюцию, по которой страны - члены $00 \mathrm{H}$ призывались к оценке состояния счастья своего народа для использования его показателей в качестве ориентира дальнейшего развития. Под эгидой $00 \mathrm{H}$ исследование этого показателя регулярно проводится действующим при Колумбийском университете исследовательским центром «Институт Земли» (The Earth Institute) [19], обобщающим такие показатели по странам, как уровень ВВП на душу населения, ожидаемая продолжительность жизни, наличие гражданских свобод, чувство безопасности и уверенности в завтрашнем дне, стабильность семей, гарантии занятости, уровень коррупции, а также косвенные показатели состояния общества, такие как уровень доверия, великодушие и щедрость. Институт Гэллапа [4] проводит опросы общественного мнения по разным странам. Результаты этих исследований обобщаются в международном докладе World Happiness Report. Все доклады о проведенных исследованиях доступны на сайте в сети Интернет [15-18; 20].

Однако насколько сильно происходящие в мире события влияют на текущее понимание этой категории, а соответственно, и на позицию страны в мировом рейтинге индекса счастья?

Методика. Мы решили понять, какие характеристики эмоционально-смыслового фона окружающих событий влияют на переживание счастья в разных странах. По нашему мнению, изменение позиции страны в мировом индексе счастья должно быть связано с адекватностью понимания ее руководством реальных перспектив развития.

Для проверки этой гипотезы мы решили сопоставить позиции разных стран в ежегодных рейтингах индекса счастья с получаемыми нами с такой же регулярностью русскоязычными информационными потоками, обрабатываемыми средствами социоматического анализа.

Напомним, что под социоматическим анализом мы понимаем новую технологию оценки эмоционально-смыслового фона выбранной целевой социальной ситуации, имеющей текстовое описание, которое оценивается по присутствию в этом описании семантических ядер, располагаемых на поверхности Социомы (социальной матрицы) этой ситуации. Эта система уникальна, представляет собой авторскую методику (была разработана В.Г. Панушкиным [8]. - Примеч. ред.) и постоянно используется с октября 2013 года по текущий момент средствами интернет-проекта socioma.ru. Социома представляет собой поле из 256 ячеек, каждая из которых имеет строго закрепленное за этой ячейкой словесное обозначение, единственным словом характеризующее отношения между людьми, свойственные только этой ячейке. Человек, переживая те или иные эмоции, всегда вынужден их ясно обозначать в своей устной или письменной речи, стараясь максимально точно подбирать слова, чтобы 
его так же максимально точно поняли окружающие. Неверно подобранное слово исказит смысл обращения, что повлечет за собой цепочку вероятных ошибок.

Социоматический анализ предполагает, что любые эмоции есть постоянно меняющийся микс четырех базовых отношений ЭГО, ПСИ, ГОС и РОД. Они характеризуют направленность во взаимодействии с окружающими на личное обогащение (ЭГО - Обмен), эмоциональное понимание (ПСИ - Ожидания), регулирование (ГОС - Принуждение) или переживание собственного физического состояния (РОД).

На текущий момент словарь русскоязычной версии Социомы составляет около 50000 слов во всех их формах, включая русскоязычную ненормативную лексику. Это позволяет оценивать эмоционально-смысловой фон почти любого текста, не несущего в себе отвлеченной образности. По получаемым данным о присутствии семантических ядер в изучаемом тексте рассчитываются соответствующие коэффициенты, характеризующие эмоционально-смысловое состояние ситуации, описываемой в тексте. Всего рассчитывается 20 коэффициентов.

Дискретность характеризует количество ячеек в секторе со значениями больше 0. Чем больше таких ячеек, тем больше показатель дискретности. Коэффициент дискретности рассчитывается отдельно для каждого сектора матрицы:

1) Дискретность по сектору «Обмен»;

2) Дискретность по сектору «0жидания»;

3) Дискретность по сектору «Принуждение»;

4) Дискретность по сектору «Состояние».

Напряженность - общее значение по конкретному сектору, сумма всех его значений. Как и Дискретность, Напряженность рассчитывается отдельно для каждого сектора матрицы:

1) Напряженность по сектору «0бмен»;

2) Напряженность по сектору «Ожидания»;

3) Напряженность по сектору «Принуждение»;

4) Напряженность по сектору «Состояние».

Значимость секторов характеризует удельный вес Напряженности для каждой ячейки в каждом секторе и рассчитывается, как отношение показателя Напряженности сектора к показателю Дискретности этого же сектора:

1) Значимость по сектору «Обмен»;

2) Значимость по сектору «Ожидания»;

3) Значимость по сектору «Принуждение»;

4) Значимость по сектору «Состояние».

Дополнительные коэффициенты по показателю Напряженности:

1) Демократичность рассчитывается как отношение Напряженности сектора «0бмен» к показателю Напряженности сектора «Принуждение»;

2) Тревожность рассчитывается как отношение Напряженности сектора «Состояние» к Напряженности сектора «Ожидание»;

3) Решительность рассчитывается как отношение коэффициента «Демократичность» к значению коэффициента «Тревожность»;

4) Широта диапазона сознания рассчитывается как разность значений коэффициента «Тревожность» и коэффициента «Решительность»;

5) Подготовка рассчитывается как отношение Напряженности сектора «Ожидание» к Напряженности сектора «0бмен»;

6) Исполнение рассчитывается как отношение Напряженности сектора «Состояние» к Напряженности сектора «0бмен»;

7) Страх рассчитывается как отношение Напряженности сектора «Принуждение» к Напряженности сектора «Ожидание»;

8) Сосредоточенность рассчитывается как отношение Напряженности сектора «Состояние» к Напряженности сектора «Принуждение». 
Нам необходимо увидеть, существуют ли какие-либо зависимости между позициями стран в рейтинге счастья за определенный год и коэффициентами Социомы этих стран за этот же год. Если такие корреляции будут обнаружены, это позволит понять, какие психологические механизмы определяют текущую позицию той или иной страны в общемировом рейтинге счастья. Несмотря на то что мы ежедневно собираем и анализируем текущую новостную информацию по всем странам мира и почти по всем странам Институт Гэллапа проводит расчет индекса счастья, не всегда индекс счастья рассчитывается с желаемой регулярностью.

Вместе с тем, обрабатывая информационные потоки по странам средствами портала socioma.ru, нам также приходится сталкиваться с нерегулярно публикуемой информацией о стране либо с постоянным повтором одной и той же информации. Кроме того, существует и большое количество чисто технических ограничений, не способствующих получению нами информации с желаемой частотой. Это, в том числе, и сбои в работе разных интернет-серверов, хакерские атаки, которым несколько раз подвергался наш ресурс, что требовало времени на восстановление работоспособности системы или отдельных ее частей. Другими словами, для дальнейшего анализа нами были отобраны только те страны, которые присутствуют и в нашей системе, и в ежегодных отчетах Института Гэллапа. Всего было отобрано 60 стран.

Результаты. В таблице 1 представлен список стран мира со значениями их индекса счастья на определенный год, по данным Института Гэллапа.

Таблица 1

Индексы счастья отобранных для дальнейшего исследования стран по годам (страны отсортированы по алфавиту)

\begin{tabular}{|c|l|c|c|c|c|c|}
\hline № n/n & \multicolumn{1}{|c|}{ Отобранные страны мира } & \multicolumn{5}{|c|}{ Индексы счастья по годам } \\
\hline & & $\mathbf{2 0 1 4}$ & $\mathbf{2 0 1 5}$ & $\mathbf{2 0 1 6}$ & $\mathbf{2 0 1 7}$ & $\mathbf{2 0 1 8}$ \\
\hline 1 & Австралия & $\mathbf{7 , 3 5 0}$ & $\mathbf{7 , 2 8 4}$ & 7,313 & 7,284 & 7,272 \\
\hline 2 & Австрия & $\mathbf{7 , 3 6 9}$ & $\mathbf{7 , 2 0 0}$ & 7,119 & 7,006 & 7,139 \\
\hline 3 & Азербайджан & $\mathbf{4 , 6 0 4}$ & 5,212 & 5,291 & 5,234 & 5,201 \\
\hline 4 & Албания & 5,550 & $\mathbf{4 , 9 5 9}$ & 4,655 & $\mathbf{4 , 6 4 4}$ & 4,586 \\
\hline 5 & Алжир & 5,422 & 5,605 & 6,355 & 5,872 & 5,295 \\
\hline 6 & Армения & 4,316 & 6,574 & 4,360 & 4,376 & 3,795 \\
\hline 7 & Босния и Герцеговина & 4,813 & 5,960 & 5,163 & 5,182 & 6,388 \\
\hline 8 & Великобритания & 6,883 & 5,813 & 6,725 & 6,714 & 4,321 \\
\hline 9 & Венгрия & 4,775 & 6,937 & 5,145 & 5,324 & 3,632 \\
\hline 10 & Венесуэла & 7,039 & 6,810 & 6,084 & 5,250 & 5,752 \\
\hline 11 & Вьетнам & 5,533 & 5,360 & 5,061 & 5,074 & 5,129 \\
\hline 12 & Германия & 6,672 & 6,750 & 6,994 & 6,951 & 6,419 \\
\hline 13 & Греция & 5,435 & 4,857 & 5,033 & 5,227 & 6,814 \\
\hline 14 & Дания & 7,693 & 7,527 & 7,526 & 7,522 & 5,620 \\
\hline 15 & Израиль & 7,301 & 7,278 & 7,267 & 7,213 & 4,806 \\
\hline 16 & Ирландия & 7,076 & 6,940 & 6,907 & 6,977 & 5,103 \\
\hline 17 & Исландия & 7,355 & 7,561 & 7,501 & 7,504 & 6,965 \\
\hline 18 & Испания & 6,322 & 6,329 & 6,361 & 6,403 & 5,504 \\
\hline 19 & Италия & 6,021 & 5,948 & 5,977 & 5,964 & 5,430 \\
\hline 20 & Казахстан & 5,671 & 5,855 & 5,919 & 5,819 & 7,555 \\
\hline 21 & Канада & 7,477 & 7,427 & 7,404 & 7,316 & 5,358 \\
\hline 22 & Кипр & 6,466 & 5,689 & 5,546 & 5,621 & 7,190 \\
\hline 23 & Китай & 4,978 & 5,140 & 5,245 & 6,422 & 5,093 \\
\hline 24 & Колумбия & 6,416 & 6,477 & 6,481 & 6,357 & 6,977 \\
\hline
\end{tabular}


психология

\begin{tabular}{|c|c|c|c|c|c|c|}
\hline \multicolumn{7}{|c|}{ Окончание таблицы 1} \\
\hline \multirow[t]{2}{*}{ № $n / n$} & \multirow[t]{2}{*}{ Отобранные страны мира } & \multicolumn{5}{|c|}{ Индексы счастья по годам } \\
\hline & & 2014 & 2015 & 2016 & 2017 & 2018 \\
\hline 25 & Кыргызстан & 5,042 & 5,286 & 5,185 & 5,004 & 6,310 \\
\hline 26 & Латвия & 5,046 & 5,098 & 5,560 & 5,850 & 6,000 \\
\hline 27 & Литва & 5,426 & 5,833 & 5,813 & 5,902 & 6,374 \\
\hline 28 & Люксембург & 7,054 & 6,946 & 6,871 & 6,863 & 5,762 \\
\hline 29 & Маврикий & 5,477 & 5,477 & 5,648 & 5,629 & 5,246 \\
\hline 30 & Мальта & 5,964 & 5,007 & 6,488 & 6,527 & 7,072 \\
\hline 31 & Мексика & 7,088 & 7,187 & 6,778 & 6,578 & 6,083 \\
\hline 32 & Молдова & 5,791 & 5,889 & 5,897 & 5,838 & 5,131 \\
\hline 33 & Монголия & 4,834 & 4,874 & 4,907 & 4,955 & 5,933 \\
\hline 34 & Нигерия & 5,248 & 5,268 & 4,875 & 5,074 & 5,199 \\
\hline 35 & Нидерланды & 7,512 & 7,378 & 7,339 & 7,377 & 5,566 \\
\hline 36 & Норвегия & 7,655 & 7,522 & 7,498 & 7,537 & 5,952 \\
\hline 37 & 0бъединенные Арабские Эмираты & 7,144 & 6,901 & 6,573 & 6,648 & 6,910 \\
\hline 38 & Польша & 5,822 & 5,791 & 5,835 & 5,973 & 5,891 \\
\hline 39 & Португалия & 5,101 & 5,102 & 5,123 & 5,195 & 5,185 \\
\hline 40 & Россия & 5,464 & 5,716 & 5,856 & 5,963 & 6,627 \\
\hline 41 & Саудовская Аравия & 6,480 & 6,411 & 6,379 & 6,344 & 5,254 \\
\hline 42 & Сербия & 4,813 & 5,123 & 5,177 & 5,395 & 6,488 \\
\hline 43 & Сингапур & 6,564 & 6,798 & 6,739 & 6,572 & 5,640 \\
\hline 44 & Словакия & 5,969 & 5,995 & 6,078 & 6,098 & 5,125 \\
\hline 45 & Словения & 6,060 & 5,848 & 5,768 & 5,758 & 6,322 \\
\hline 46 & Соединенные Штаты Америки & 7,082 & 7,119 & 7,104 & 6,993 & 5,155 \\
\hline 47 & Таджикистан & 4,380 & 4,786 & 4,996 & 5,041 & 7,441 \\
\hline 48 & Таиланд & 6,371 & 6,455 & 6,474 & 6,424 & 7,324 \\
\hline 49 & Туркменистан & 5,628 & 5,548 & 5,658 & 5,822 & 7,594 \\
\hline 50 & Турция & 5,345 & 5,332 & 5,389 & 5,500 & 6,774 \\
\hline 51 & Узбекистан & 5,623 & 6,003 & 5,987 & 5,971 & 6,430 \\
\hline 52 & Филиппины & 4,985 & 5,073 & 5,279 & 5,430 & 5,681 \\
\hline 53 & Финляндия & 7,389 & 7,406 & 7,413 & 7,469 & 5,663 \\
\hline 54 & Франция & 6,764 & 6,575 & 6,478 & 6,442 & 6,123 \\
\hline 55 & Хорватия & 5,661 & 5,759 & 5,488 & 5,293 & 5,410 \\
\hline 56 & Чехия & 6,290 & 6,505 & 6,596 & 6,609 & 5,810 \\
\hline 57 & Швейцария & 7,650 & 7,587 & 7,509 & 7,494 & 5,945 \\
\hline 58 & Швеция & 7,480 & 7,364 & 7,291 & 7,284 & 6,167 \\
\hline 59 & Эстония & 5,426 & 5,429 & 5,517 & 5,611 & 6,371 \\
\hline 60 & Южная Корея & 6,267 & 5,984 & 5,835 & 5,838 & 5,398 \\
\hline
\end{tabular}

Чтобы избежать субъективизма, нами подбиралось не менее трех информационных потоков, не связанных друг с другом. Приняв общее значение Социомы за 100\%, или за 1, мы получаем возможность рассчитать вес каждой отдельной ячейки как долю к общему значению всей матрицы. При этом мы понимаем, что получаемые нами тексты никто никогда не будет создавать под наши требования. Их авторы могут использовать любые слова, которые они сочтут необходимыми. Кроме того, получая первичные тексты с сайтов, мы очевидно будем получать большое количество разнообразных слов, имеющих чисто технический характер, поясняющий рисунки, рубрики навигации сайта, упоминание рекламодателей или партне- 
ров, почтовые адреса и другие выходные реквизиты сайта и так далее. Но, несмотря на весь этот «мусор», увеличивающий смысловой шум, мы знаем, что Социома ведет свои расчеты только исходя из своего собственного тезауруса, а поэтому этот шум не будет оказывать сколько-нибудь серьезного влияния на итоговые результаты. Для иллюстрации полученных по каждой стране данных Социомы из-за необходимых редакционных ограничений по объему текста статьи мы приведем здесь итоговые данные только по одному из наших коэффициентов - значения коэффициента Демократичности по всем названным странам (табл. 2).

Таблица 2

Значения коэффициента Демократичности по каждой из выбранных стран (страны отсортированы по алфавиту)

\begin{tabular}{|c|c|c|c|c|c|c|}
\hline \multirow{2}{*}{$\begin{array}{c}\text { № } \\
\pi / \Pi\end{array}$} & \multirow[t]{2}{*}{ Отобранные страны мира } & \multicolumn{5}{|c|}{ Значения коэффициента Демократичности } \\
\hline & & 2014 & 2015 & 2016 & 2017 & 2018 \\
\hline 1 & Австралия & 1,069 & 0,978 & 0,984 & 1,503 & 1,214 \\
\hline 2 & Австрия & 1,173 & 1,146 & 1,095 & 1,056 & 1,146 \\
\hline 3 & Азербайджан & 1,002 & 1,061 & 0,886 & 0,863 & 0,989 \\
\hline 4 & Албания & 1,226 & 1,184 & 1,121 & 1,684 & 1,453 \\
\hline 5 & Алжир & 0,989 & 1,156 & 0,916 & 1,113 & 1,052 \\
\hline 6 & Армения & 1,072 & 1,111 & 0,938 & 0,978 & 0,970 \\
\hline 7 & Босния и Герцеговина & 1,220 & 1,238 & 1,221 & 1,509 & 1,309 \\
\hline 8 & Великобритания & 1,258 & 1,272 & 1,243 & 1,251 & 1,541 \\
\hline 9 & Венгрия & 1,177 & 1,162 & 1,179 & 1,461 & 1,333 \\
\hline 10 & Венесуэла & 0,861 & 1,021 & 0,951 & 0,907 & 1,038 \\
\hline 11 & Вьетнам & 1,417 & 1,334 & 1,169 & 1,406 & 1,199 \\
\hline 12 & Германия & 1,255 & 1,236 & 1,111 & 1,153 & 1,149 \\
\hline 13 & Греция & 1,276 & 1,388 & 1,232 & 1,635 & 1,368 \\
\hline 14 & Дания & 1,253 & 1,259 & 1,269 & 1,235 & 1,168 \\
\hline 15 & Израиль & 1,060 & 0,990 & 0,971 & 0,959 & 0,999 \\
\hline 16 & Ирландия & 1,311 & 1,327 & 1,460 & 1,083 & 0,919 \\
\hline 17 & Исландия & 1,439 & 1,413 & 1,322 & 1,792 & 1,370 \\
\hline 18 & Испания & 1,208 & 1,221 & 1,214 & 1,100 & 1,132 \\
\hline 19 & Италия & 1,158 & 1,202 & 1,196 & 1,126 & 1,112 \\
\hline 20 & Казахстан & 1,027 & 1,067 & 1,011 & 0,860 & 0,856 \\
\hline 21 & Канада & 1,250 & 1,377 & 1,320 & 1,291 & 1,189 \\
\hline 22 & Кипр & 1,280 & 1,345 & 1,189 & 1,998 & 1,258 \\
\hline 23 & Китай & 1,172 & 1,157 & 1,091 & 1,062 & 1,171 \\
\hline 24 & Колумбия & 0,932 & 1,040 & 1,128 & 0,967 & 1,028 \\
\hline 25 & Кыргызстан & 0,977 & 1,042 & 0,953 & 1,245 & 1,057 \\
\hline 26 & Латвия & 1,076 & 1,058 & 1,025 & 1,059 & 1,070 \\
\hline 27 & Литва & 1,133 & 1,132 & 1,049 & 1,039 & 1,032 \\
\hline 28 & Люксембург & 1,225 & 1,412 & 1,484 & 1,326 & 0,997 \\
\hline 29 & Маврикий & 1,194 & 0,690 & 1,847 & 1,719 & 1,272 \\
\hline 30 & Мальта & 1,259 & 1,360 & 1,412 & 0,941 & 0,946 \\
\hline 31 & Мексика & 1,203 & 1,612 & 1,235 & 1,139 & 1,437 \\
\hline 32 & Молдова & 1,107 & 1,185 & 1,062 & 1,394 & 1,154 \\
\hline 33 & Монголия & 0,971 & 1,105 & 1,325 & 1,335 & 1,271 \\
\hline 34 & Нигерия & 0,911 & 1,447 & 1,442 & 0,854 & 0,810 \\
\hline
\end{tabular}


психология

Окончание таблищы 2

\begin{tabular}{|c|l|c|c|c|c|c|}
\hline $\begin{array}{c}\text { № } \\
\text { п/n }\end{array}$ & \multicolumn{1}{|c|}{ Отобранные страны мира } & \multicolumn{5}{|c|}{ 3начения коэффициента Демократичности } \\
\hline & & $\mathbf{2 0 1 4}$ & $\mathbf{2 0 1 5}$ & $\mathbf{2 0 1 6}$ & $\mathbf{2 0 1 7}$ & $\mathbf{2 0 1 8}$ \\
\hline 35 & Нидерланды & 1,140 & 1,101 & 1,127 & 1,408 & 1,647 \\
\hline 36 & Норвегия & 1,208 & 1,263 & 1,180 & 2,149 & 1,020 \\
\hline 37 & Объединенные Арабские Эмираты & 1,165 & 1,184 & 1,022 & 1,185 & 1,162 \\
\hline 38 & Польша & 1,165 & 1,176 & 0,979 & 0,939 & 0,990 \\
\hline 39 & Португалия & 1,337 & 1,376 & 1,348 & 1,408 & 1,225 \\
\hline 40 & Россия & 0,878 & 0,939 & 0,966 & 0,984 & 0,946 \\
\hline 41 & Саудовская Аравия & 0,907 & 0,836 & 0,918 & 1,273 & 1,189 \\
\hline 42 & Сербия & 1,198 & 1,165 & 1,175 & 1,183 & 1,187 \\
\hline 43 & Сингапур & 1,477 & 1,233 & 1,251 & 1,227 & 1,225 \\
\hline 44 & Словакия & 1,264 & 1,275 & 1,255 & 0,978 & 1,087 \\
\hline 45 & Словения & 1,189 & 1,333 & 1,217 & 1,110 & 0,932 \\
\hline 46 & Соединенные Штаты Америки & 1,129 & 1,078 & 1,075 & 1,179 & 0,786 \\
\hline 47 & Таджикистан & 0,989 & 1,012 & 0,866 & 0,889 & 0,741 \\
\hline 48 & Таиланд & 1,043 & 0,967 & 0,946 & 1,027 & 0,532 \\
\hline 49 & Туркменистан & 0,974 & 1,046 & 1,064 & 1,079 & 0,633 \\
\hline 50 & Турция & 1,094 & 1,004 & 0,859 & 0,923 & 0,797 \\
\hline 51 & Узбекистан & 1,035 & 1,034 & 0,967 & 1,019 & 0,700 \\
\hline 52 & Филиппины & 1,248 & 1,684 & 1,039 & 1,067 & 0,675 \\
\hline 53 & Финляндия & 1,216 & 1,217 & 1,111 & 1,184 & 0,752 \\
\hline 54 & Франция & 1,239 & 1,142 & 1,057 & 1,105 & 0,803 \\
\hline 55 & Хорватия & 1,240 & 1,279 & 1,160 & 1,812 & 0,775 \\
\hline 56 & Чехия & 1,130 & 1,179 & 1,112 & 1,281 & 1,499 \\
\hline 57 & Швейцария & 1,257 & 1,253 & 1,272 & 1,365 & 1,130 \\
\hline 58 & Швеция & 1,295 & 1,185 & 1,138 & 1,195 & 1,097 \\
\hline 59 & Эстония & 1,115 & 1,117 & 1,089 & 1,080 & 0,997 \\
\hline 60 & Южная Корея & 1,074 & 1,042 & 1,044 & 1,278 & 1,323 \\
\hline & & & & & \\
\hline
\end{tabular}

0бсуждение. Теперь рассмотрим некоторые значения полученных нами в ходе исследования значений корреляций индексов счастья выбранных стран и коэффициентов Социомы этих стран за те же годы (табл. 3).

Таблица 3

Корреляции коэффициентов Дискретности по секторам и индекса счастья по годам

\begin{tabular}{|c|c|c|c|c|}
\hline Год & \multicolumn{4}{|c|}{$\begin{array}{c}\text { Корреляции коэффициентов Дискретности } \\
\text { по секторам и индекса счастья по годам }\end{array}$} \\
\hline & $\mathbf{0 6 м е н ~}$ & Ожидания & Принуждение & Состояние \\
\hline 2014 & 0,22 & 0,21 & $-0,10$ & 0,24 \\
\hline 2015 & $-0,05$ & $-0,02$ & $-0,13$ & 0,01 \\
\hline 2016 & 0,01 & 0,07 & $-0,26$ & $-0,09$ \\
\hline 2017 & $-0,03$ & 0,15 & $-0,18$ & 0,01 \\
\hline 2018 & 0,09 & 0,26 & 0,27 & 0,22 \\
\hline Графики динамики & & & & \\
\hline & 1 & & & \\
\hline
\end{tabular}


Как видно из представленных в таблице 3 данных, все полученные корреляции имеют слабо выраженный характер. В то же время, мы думаем, было бы наивно предполагать высоких или даже средних корреляций между информацией отдельных СМИ и данными глобальных научных исследований, проводимых многотысячной группой мировых ученых.

Вместе с тем, как видно из представленных цифр и графиков, заметна общая тенденция к снижению корреляций на рубеже 2016-2017 годов и восстановление ее в 2018 году. Коэффициент Дискретности, замеряя количество активных ячеек на поверхности Социомы, говорит нам о разнообразии семантических ядер текста, разноплановости смысловых тем по тому или иному направлению. Если вспомнить наиболее значимые мировые события анализируемого временного периода (решение Великобритании о выходе из состава Евросоюза (2016 г.), война в Сирии (2015-2018 гг.), события на Украине (2014 г.), выборы Д. Трампа президентом США (2016 г.), жесткое противостояние России и Запада и ряд других), становится понятным, почему число смысловых тем, связанных с принуждением, особенно возросло в 2018 году. Эту же мысль подтверждают данные таблицы 4, отражающие корреляции коэффициента Напряженности по секторам и индексами счастья.

Таблица 4

Корреляции коэффициентов Напряженности по секторам и индекса счастья по годам

\begin{tabular}{|c|c|c|c|c|}
\hline Год & \multicolumn{4}{|c|}{$\begin{array}{c}\text { Корреляции коэффициентов Напряженности } \\
\text { по секторам и индекса счастья по годам }\end{array}$} \\
\hline & $\mathbf{0 б м е н ~}$ & Ожидания & Принуждение & Состояние \\
\hline 2014 & 0,17 & 0,20 & $-0,01$ & 0,40 \\
\hline 2015 & 0,04 & 0,05 & $-0,05$ & $-0,04$ \\
\hline 2016 & 0,11 & 0,11 & $-0,21$ & 0,02 \\
\hline 2017 & $-0,08$ & 0,13 & $-0,27$ & 0,14 \\
\hline 2018 & $-0,20$ & 0,09 & 0,09 & $-0,05$ \\
\hline Графики динамики & & & - & \\
\hline & & & & \\
\hline
\end{tabular}

Сравнивая данные таблиц 3 и 4, мы заметим, что если количество смысловых тем, связанных с обменом и взаимодействием (табл. 3, график 1), к 2018 году стало расти, то общая Напряженность сектора «0бмен» (табл. 4, график 5) к 2018 году, напротив, стала падать. При этом наряду с увеличением Дискретности по сектору «Принуждение» (табл. 3, график 3) увеличивается и Напряженность по сектору «Принуждение» (табл. 4, график 7), что, на наш взгляд, говорит о нарастании общественной заинтересованности в секторе «Принуждение» больше, чем в секторе обмена и взаимодействия. Это говорит, как нам кажется, о вероятности еще большего военно-политического и экономического мирового противостояния в 2019 году. Именно эту картину мы видим сейчас на мировой арене, в мае 2019 года, когда США стали выступать в конфронтации не только к России и Евросоюзу, но и к одному из крупнейших мировых индустриальных игроков - Китаю, - введя против него высокие ограничительные ввозные пошлины и фактически объявив торговую войну мировому китайскому гиганту - компании «Нuawei».

Эту же, не самую радужную, перспективу отражают данные таблицы 5. Из них видно, что в изучаемый период времени потребность в Демократичности (график 9) значительно упала, потребовав более внимательной работы и сосредоточенности на текущей мировой ситуации. Казалось бы, увеличившиеся значения Широты сознания (график 10) в 2016 году, связанные с избранием президентом США Д. Трампа, сменившего десятилетиями правившую верхушку Клинтонов и Бушей, должна была нормализовать эмоционально-смысловую ситу- 
ацию в мире, но последующие хаотичные и жесткие действия нового президента США обострили общемировую ситуацию.

Таблица 5

Корреляции некоторых коэффициентов по Напряженности и индекса счастья по годам

\begin{tabular}{|c|c|c|c|c|}
\hline Год & \multicolumn{4}{|c|}{ Корреляции некоторых коэффициентов по Напряженности } \\
и индекса счастья по годам \\
\hline & Демократичность & $\begin{array}{c}\text { Широта диапазо- } \\
\text { на сознания }\end{array}$ & Страх & $\begin{array}{c}\text { Сосредоточен- } \\
\text { ность }\end{array}$ \\
\hline 2014 & 0,29 & 0,02 & 0,16 & $-0,20$ \\
\hline 2015 & 0,05 & $-0,10$ & 0,05 & $-0,06$ \\
\hline 2016 & 0,12 & 0,21 & 0,12 & $-0,10$ \\
\hline 2017 & 0,10 & $-0,06$ & 0,15 & $-0,14$ \\
\hline 2018 & $-0,29$ & 0,02 & $-0,11$ & 0,18 \\
\hline График динамики & & - & - & - \\
\hline & 9 & 10 & 11 & 12 \\
\hline
\end{tabular}

Заключение и выводы. Мы смогли показать лишь некоторые данные сопоставления индекса счастья Института Гэллапа и получаемых нами результатов исследований эмоционально-смыслового фона мировых СМИ средствами социоматического анализа. Полученные результаты показывают, что, хотя выявленные корреляции имеют небольшие значения по абсолютной величине, своей динамикой, достигающей порой 40 процентных пунктов, они отражают реальный текущий эмоционально-смысловой фон отдельной страны и мира в целом. Это позволяет нам сделать следующие выводы.

1. Удалось подтвердить нашу первоначальную гипотезу о том, что существующий в странах мира эмоционально-смысловой фон, лежащий в основе формирования комплексного показателя индекса счастья, рассчитываемого Институтом Гэллапа по каждой стране, в большой мере определяется текущими общемировыми событиями, требующими от стран адекватных действий, предварительно выражающихся в текущем эмоциональном состоянии населения этих стран.

2. Рассматривая корреляции между разными явлениями, важно видеть не только величину получаемого коэффициента, но и динамику этого коэффициента, что позволяет сделать лучший прогноз развития событий.

\section{Список литературы}

1. Али-заде А.А. Абдулла ибн Салам // Исламский энциклопедический словарь. М.: Ансар, 2007. 400 с. (Золотой фонд исламской мысли).

2. Всемирный индекс счастья New Economic Foundation // Гуманитарная энциклопедия. URL: https://gtmarket.ru/ratings/happy-planet-index/info (дата обращения: 27.05.2019).

3. Достоевский Ф.М. Идиот. СПб.: Азбука-классика, 2009. 637 с.

4. Индекс счастья 2012-2014 // Priroda.SU. URL: http://www.priroda.su/item/8423/ (дата обращения: 27.05.2019).

5. Лавров И.В. Развитие методологии исследования экономики благосостояния на основе теории элит: автореф. дис. ... д-ра экон. наук. Екатеринбург, 2009. 41 с.

6. Макропсихология современного российского общества: монография / отв.ред.: А.Л. Журавлев, А.В. Юревич. М.: Ин-т психологии РАН, 2009. 350 с.

7. Панушкин В.Г. Возможность прогноза курсов валют средствами анализа Социомы валютного рынка // Маркетинг в России и за рубежом. 2014. № 2.

8. Панушкин В.Г. Социома (социальная матрица). М.: Перо, 2018.

9. Первая страница / Организация Объединенных Наций. URL: https://www.un.org/ru/ (дата обращения: 27.05.2019). 
10. Рейтинг стран по уровню счастья. URL: https://nonews.co/directory/lists/countries/ happiness-rating/ (дата обращения: 27.05.2019).

11. Степанова Д.А. Взаимодействие лексики и фразеологии в системе языка: на материале наименований положительных чувств и эмоций в русском и английском языках: автореф. дис. ... канд. филол. наук. Воронеж, 2009. 19 с.

12. Хораськина Н.С. Качество жизни как социально-философская категория: автореф. дис. ... канд. филос. наук. Чебоксары, 2009. 19 с.

13. Ягудин Р.Х. Регулирование качества жизни в трансформационной экономике: автореф. дис. ... канд. экон. наук. Казань, 2009. 24 с.

14. Analytics \& Advice About Everything That Matters. URL: https://www.gallup.com/ (date of access: 27.05.2019).

15. Helliwell, J., Layard, R., \& Sachs, J. (2016). World Happiness Report 2016, Update (Vol. I). N.Y.: Sustainable Development Solutions Network. URL: https://worldhappiness.report/ed/2016/ (date of access: 27.05.2019).

16. Helliwell, J., Layard, R., \& Sachs, J. (2017). World Happiness Report 2017. N.Y.: Sustainable Development Solutions Network. URL: https://worldhappiness.report/ed/2017/ (date of access: 27.05.2019).

17. Helliwell, J., Layard, R., \& Sachs, J. (2018). World Happiness Report 2018. N.Y.: Sustainable Development Solutions Network. URL: https://worldhappiness.report/ed/2018/ (date of access: 27.05.2019).

18. Helliwell, J.F., Layard R., and Sachs J., eds. (2015). World Happiness Report 2015. N.Y. Sustainable Development Solutions Network. URL: https://worldhappiness.report/ ed/2015/ (date of access: 27.05.2019).

19. The Earth Institute - Columbia University. URL: https://www.earth.columbia.edu/ (date of access: 27.05.2019).

20. World Happiness Report 2014 / Sustainable Development Solutions Network. URL: https:// www.earth.columbia.edu/sitefiles/file/Sachs\%2520Writing/2014/ (date of access: 27.05.2019).

\section{References}

1. Ali-zade A.A. Abdulla ibn Salam // Islamskij enciklopedicheskij slovar'. M.: Ansar, 2007. 400 s. (Zolotoj fond islamskoj mysli).

2. Vsemirnyj indeks schast'ya New Economic Foundation // Gumanitarnaya enciklopediya. URL: https://gtmarket.ru/ratings/happy-planet-index/info (data obrashcheniya: 27.05.2019).

3. Dostoevskij F.M. Idiot. SPb.: Azbuka-klassika, 2009. $637 \mathrm{s.}$

4. Indeks schast'ya 2012-2014 // Priroda.SU. URL: http://www.priroda.su/item/8423/ (data obrashcheniya: 27.05.2019).

5. Lavrov I.V. Razvitie metodologii issledovaniya ekonomiki blagosostoyaniya na osnove teorii elit: avtoref. dis. ... d-ra ekon. nauk. Ekaterinburg, 2009. $41 \mathrm{s.}$

6. Makropsikhologiya sovremennogo rossijskogo obshchestva: monografiya / otv.red.: A.L. Zhuravlev, A.V. Yurevich. M.: In-t psikhologii RAN, 2009. $350 \mathrm{~s}$.

7. Panushkin V.G. Vozmozhnost' prognoza kursov valyut sredstvami analiza Sociomy valyutnogo rynka // Marketing v Rossii i za rubezhom. 2014. № 2.

8. Panushkin V.G. Socioma (social'naya matrica). M.: Pero, 2018.

9. Pervaya stranica / Organizaciya Ob"edinennykh Nacij. URL: https://www.un.org/ru/ (data obrashcheniya: 27.05.2019).

10. Rejting stran po urovnyu schast'ya. URL: https://nonews.co/directory/lists/countries/ happiness-rating/ (data obrashcheniya: 27.05.2019).

11. Stepanova D.A. Vzaimodejstvie leksiki i frazeologii $v$ sisteme yazyka: na materiale naimenovanij polozhitel'nykh chuvstv i emocij v russkom i anglijskom yazykakh: avtoref. dis. ... kand. filol. nauk. Voronezh, 2009. 19 s.

12. Khoras'kina N.S. Kachestvo zhizni kak social'no-filosofskaya kategoriya: avtoref. dis. ... kand. filos. nauk. Cheboksary, 2009. 19 s.

13. Yagudin R.Kh. Regulirovanie kachestva zhizni $v$ transformacionnoj ekonomike: avtoref. dis. ... kand. ekon. nauk. Kazan', 2009. 24 s.

14. Analytics \& Advice About Everything That Matters. URL: https://www.gallup.com/ (date of access: 27.05.2019). 
15. Helliwell, J., Layard, R., \& Sachs, J. (2016). World Happiness Report 2016, Update (Vol. I). N.Y.: Sustainable Development Solutions Network. URL: https://worldhappiness.report/ed/2016/ (date of access: 27.05.2019).

16. Helliwell, J., Layard, R., \& Sachs, J. (2017). World Happiness Report 2017. N.Y.: Sustainable Development Solutions Network. URL: https://worldhappiness.report/ed/2017/ (date of access: 27.05.2019).

17. Helliwell, J., Layard, R., \& Sachs, J. (2018). World Happiness Report 2018. N.Y.: Sustainable Development Solutions Network. URL: https://worldhappiness.report/ed/2018/ (date of access: 27.05.2019).

18. Helliwell, J.F., Layard R., and Sachs J., eds. (2015). World Happiness Report 2015. N.Y. Sustainable Development Solutions Network. URL: https://worldhappiness.report/ ed/2015/ (date of access: 27.05.2019).

19. The Earth Institute - Columbia University. URL: https://www.earth.columbia.edu/ (date of access: 27.05.2019).

20. World Happiness Report 2014 / Sustainable Development Solutions Network. URL: https:// www.earth.columbia.edu/sitefiles/file/Sachs\%2520Writing/2014/ (date of access: 27.05.2019).

\section{Библиографическое описание статьи / Reference to article}

Панушкин В.Г. Социоматический анализ как инструмент оценки мотивационной характеристики индекса счастья стран мира // Ученые записки Российского государственного социального университета. Т. 19. 2020. № 1 (154). C. 17-27. DOI: 10.17922/2071-53232020-19-1-17-27 (Библиографическое описание согласно российским стандартам).

Panushkin V.G. Sociomaticheskij analiz kak instrument ocenki motivacionnoj kharakteristiki indeksa schast'ya stran mira // Uchenye zapiski Rossijskogo gosudarstvennogo social'nogo universiteta. T. 19. 2020. № 1 (154). S. 17-27. D0I: 10.17922/2071-5323-2020-19-1-17-27 (Reference in Roman script).

Panushkin V.G. (2020) Sociomatrix Analysis As a Researching Tool of the Motivational Characteristics of the Happiness Index of World States, Scientific Notes of Russian State Social University. Vol. 19. No. 1 (154). P. 17-27. DOI: 10.17922/2071-5323-2020-19-1-17-27 (International bibliographic description). 


\section{Н.В. Белякова,}

канд. психол. наук, доцент кафедры социальной, общей и клинической

психологии, Российский государственный социальный университет, Москва.

N.V. Belyakova,

candidate of psychological sciences, associate professor of the department

of social, general and clinical psychology, Russian State Social University, Moscow.

E-mail: nbelyakova@mail.ru

\section{Д.Р. Хасанова,}

магистрантка, Российский государственный социальный университет, Москва.

D.R. Khasanova,

master student, Russian State Social University, Moscow.

E-mail: dariakh86@gmail.com

\section{Механизмы формирования социального интеллекта в подростковом возрасте}

The Mechanisms of Formation of Social Intelligence in Adolescence

\author{
Дата поступления \\ 20.12.2019
}

\author{
Дата препринта \\ 28.02.2020
}

\author{
Дата публикации \\ 30.03.2020
}

Аннотация: в статье представлены результаты магистерского исследования по теме «Психологические механизмы формирования социального интеллекта у подростков»; проводится обоснование выбранных методов исследования; приводятся статистические данные, полученные в ходе психодиагностического исследования структурных компонентов данного психологического конструкта; дается характеристика выявленной в ходе проведенного исследования функциональной взаимосвязи между структурными компонентами психологического конструкта «психологические механизмы формирования социального интеллекта»; описывается процесс разработки и апробации программы социально-психологического тренинга, направленного на развитие социального интеллекта у подростков; осуществляется анализ практической значимости полученных результатов; определяются пути их внедрения в практическую деятельность образовательных организаций, работающих с подростками.

Annotation: the article presents the results of a master's study on the topic "Psychological mechanisms of the formation of social intelligence in adolescents"; substantiation of the selected research methods is carried out; statistical data obtained during a psychodiagnostic study of the structural components of this psychological construct are given; the characteristic of the functional relationship between the structural components of the psychological construct "psychological mechanisms of the formation of social intelligence" revealed during the study is given; describes the process of developing and testing a program of socio-psychological training aimed at the development of social intelligence in adolescents; analysis of the practical significance of the results; the ways of their implementation in the practical activities of educational organizations working with adolescents are determined.

Ключевые слова: психологические механизмы формирования социального интеллекта, уровень развития социального интеллекта, личностная черта, социальный опыт, социальный контакт.

Key words: psychological mechanisms of the formation of social intelligence, level of development of social intelligence, personality trait, social experience, social contact. 
Введение. В настоящее время отсутствует четкое понимание сущности термина «социальный интеллект» [7; 8]. Д.В. Ушаков выделяет три основных подхода к определению места социального интеллекта в общей структуре психики: социальный интеллект как вид интеллекта; социальный интеллект как личностная черта; социальный интеллект как совокупность знаний $[17$, с. 11-28; 18].

Механизмы функционирования социального интеллекта обладают рядом специфических особенностей, отличающих его от других видов интеллекта:

- проблема соотношения вербальных и невербальных процессов мышления в ходе оценивания индивидом фактов наличия и степени выраженности личностных характеристик других людей (качество и точность оценочных суждений значительно снижаются в случае предварительной вербализации критериев оценивания) [1];

- апеллирование к личному опыту индивида в процессе анализа информации социального содержания (подобное сложно наблюдать в процессах, составляющих основу других видов интеллекта);

- насыщение определенного («социального») понятия дополнительными характеристиками, уникальными для каждого человека и выводимыми из его личного опыта социального взаимодействия;

- наличие взаимосвязи между уровнем развития (сформированности) социального интеллекта и степенью выраженности черт личности индивида.

Процесс формирования социального интеллекта соотносится с процессом развития личности человека и имеет сензитивные периоды для формирования определенных коммуникативных навыков. В подростковом возрасте развитие навыков общения идет по двум направлениям: общение со сверстниками и общение со взрослыми $[5 ; 6 ; 9 ; 14 ; 15]$. Данный этап развития социального интеллекта является особенно важным для дальнейшего развития личности, поскольку именно в этот период формируются поведенческие навыки, которые будут использоваться индивидом в процессах межличностного взаимодействия на протяжении всей дальнейшей жизни [10].

Опираясь на данные, полученные в результате анализа соответствующей научной психологической литературы, была выбрана методологическая база исследования (структурно-динамическая теория интеллекта Д.В. Ушакова) и сформулированы объект, предмет и задачи исследования.

В рамках данного исследования социальный интеллект рассматривался как частный вид общего интеллекта, что соответствует наиболее популярному в отечественной психологии подходу к пониманию означенного термина [2; 3].

Объектом исследования выступил социально-психологический феномен «социальный интеллект».

Предмет исследования - психологические механизмы формирования социального интеллекта у подростков.

Перечислим задачи исследования.

1. Выделение на основе анализа научной психологической литературы компонентов структурно-динамического конструкта «психологические механизмы формирования социального интеллекта у подростков» и построение модели данного психологического явления.

2. Проведение измерительных психодиагностических процедур для определения характера выраженности у испытуемых (выборки исследования) показателей, выделенных в качестве структурных компонентов конструкта «психологические механизмы формирования социального интеллекта у подростков».

3. Определение факта наличия и характера взаимосвязи между выделенными компонентами методами корреляционного анализа. 
4. Разработка и апробация на основе полученных результатов программы авторского социально-психологического тренинга, направленного на развитие социального интеллекта у подростков.

5. Разработка практических рекомендаций по внедрению полученных результатов исследования в деятельность образовательных организаций, работающих с подростками (школы, учреждения дополнительного образования).

Основная гипотеза исследования - уровень развития социального интеллекта обусловлен воздействием двух групп факторов - внешних и внутренних: к внешним факторам следует отнести количественные и качественные характеристики социального опыта индивида (число и степень разнообразия социальных контактов); к внутренним факторам - своеобразие выраженности черт личности индивида.

Исследование проводилось в пять этапов:

1) анализ научной психологической литературы;

2) определение объекта, предмета, цели, задач и гипотезы исследования;

3) выбор и разработка методик исследования, проведение диагностических процедур;

4) обработка полученных результатов методами математико-статистического анализа;

5) разработка и апробация (на основе полученных результатов) программы авторского социально-психологического тренинга развития социального интеллекта [12; 13].

Методика. В исследовании принимали участие подростки, посещавшие занятия в МБУД0 «ДДТ» г. Новозыбкова (50 юношей и 50 девушек в возрасте от 13 до 15 лет).

В проведенном исследовании использовались:

1) Тест «Социальный интеллект»; авторы - Дж. Гилфорд, М. O'Салливен; цель - определение уровня развития социального интеллекта [11];

2) Опросник Кеттелла (HSPQ - вариант для подростков); автор - Р. Кеттелл; цель - определение уровня выраженности черт личности, определяющих направленность (или отсутствие таковой) индивида на установление социальных связей [16];

3) Тест «Интроверт ты или экстраверт?»; автор 0.Н. Истратова; цель - определение уровня выраженности черт личности, определяющих направленность (или отсутствие таковой) индивида на установление социальных связей [6];

4) Авторская анкета; автор - Д.Р. Хасанова; цель - определение качественных и количественных характеристик социального опыта испытуемых.

Примененные в исследовании методы статистической обработки данных: расчет коэффициента корреляции Спирмена, расчет U-критерия Манна-Уитни.

Результаты. Результаты статистической обработки данных исследования позволили сделать вывод об отсутствии гендерных различий в выраженности у подростков следующих измеряемых в ходе исследования признаков: уровень развития социального интеллекта (методика «Социальный интеллект»), выраженность черт личности (методики: «0просник Кеттелла (HSPQ - вариант для подростков)», тест «Интроверт ты или экстраверт?»), число и степень разнообразия социальных контактов (методика «Авторская анкета»).

На следующем этапе исследования были проведены процедуры, направленные на выявление и определение меры связи между уровнем развития социального интеллекта и признаками, выбранными в качестве внешних и внутренних факторов формирования социального интеллекта у подростков.

Наиболее значимые результаты корреляционного исследования результатов диагностики по методикам «Тест “Социальный интеллект"» и «0просник Кеттелла (HSPQ - вариант для подростков)» в группе девушек представлены в таблице 1.

Из таблицы 1 видно, что уровень развития социального интеллекта коррелирует с тремя биполярными показателями выраженности черт личности: аффектомия - шизотимия (фактор $A ; r=0,78 ; p<0,05)$; премсия - харрия (фактор I; $r=-0,9 ; p<0,05) ;$ коэстения - зеппия (фактор $\mathrm{J} ; \mathrm{r}=-0,9 ; p<0,05)$. 
Результаты корреляционного анализа данных исследования по методикам «Тест "Социальный интеллект" и «Опросник Кеттелла (HSPQ - вариант для подростков)» в группе девушек

\begin{tabular}{|c|c|c|c|c|c|c|c|c|c|c|}
\hline Название & \multicolumn{10}{|c|}{ Тест «Социальный интеллект» } \\
\hline \multirow{2}{*}{$\begin{array}{c}\text { 0просник } \\
\text { Кеттелла } \\
\text { (HSPQ) }\end{array}$} & \multicolumn{2}{|c|}{ Субтест № 1} & \multicolumn{2}{|c|}{ Субтест № 2} & \multicolumn{2}{|c|}{ Субтест № 3} & \multicolumn{2}{|c|}{ Субтест № 4} & \multicolumn{2}{|c|}{ Композ. оценка } \\
\hline & $r$ & $P$ & $r$ & $P$ & $r$ & $P$ & $r$ & $P$ & $r$ & $P$ \\
\hline Фактор А & 0,71 & $p<0,05$ & 0,77 & $p<0,05$ & 0,59 & $p<0,05$ & 0,73 & $p<0,05$ & 0,78 & $p<0,05$ \\
\hline Фактор I & $-0,8$ & $p<0,05$ & $-0,9$ & $p<0,05$ & $-0,7$ & $p<0,05$ & $-0,8$ & $p<0,05$ & $-0,9$ & $p<0,05$ \\
\hline Фактор J & $-0,8$ & $p<0,05$ & $-0,8$ & $p<0,05$ & $-0,7$ & $p<0,05$ & $-0,7$ & $p<0,05$ & $-0,9$ & $p<0,05$ \\
\hline
\end{tabular}

Статистически значимые результаты корреляционного анализа данных, полученных в ходе измерения по методикам «Тест “Социальный интеллект"» и «Опросник Кеттелла (HSPQ - вариант для подростков)» в группе юношей представлены в таблице 2.

Таблица 2

Результаты корреляционного анализа данных исследования по методикам «Тест “Социальный интеллект"» и «Опросник Кеттелла (HSPQ - вариант для подростков)» в группе юношей

\begin{tabular}{|c|c|c|c|c|c|c|c|c|c|c|}
\hline & \multicolumn{10}{|c|}{ Тест «Социальный интеллект» } \\
\hline \multirow{2}{*}{$\begin{array}{c}\text { Опросник } \\
\text { Кеттелла } \\
\text { (HSPQ) }\end{array}$} & \multicolumn{2}{|c|}{ Субтест № 1} & \multicolumn{2}{|c|}{ Субтест № 2} & \multicolumn{2}{|c|}{$\begin{array}{c}\text { Субтест } \\
\text { № } 3\end{array}$} & \multicolumn{2}{|c|}{$\begin{array}{c}\text { Субтест } \\
\text { № } 4\end{array}$} & \multicolumn{2}{|c|}{ Композ. оценка } \\
\hline & $r$ & $P$ & $r$ & $P$ & $r$ & $P$ & $r$ & $P$ & $r$ & $P$ \\
\hline Фактор A & 0,51 & $p<0,05$ & 0,56 & $p<0,05$ & 0,6 & $p<0,05$ & 0,5 & $p<0,05$ & 0,61 & $p<0,05$ \\
\hline Фактор I & $-0,9$ & $\mathrm{p}<0,05$ & $-0,9$ & $p<0,05$ & $-0,8$ & $p<0,05$ & $-0,8$ & $p<0,05$ & $-0,8$ & $p<0,05$ \\
\hline Фактор J & $-0,8$ & $p<0,05$ & $-0,9$ & $p<0,05$ & $-0,7$ & $p<0,05$ & $-0,8$ & $p<0,05$ & $-0,9$ & $\mathrm{p}<0,05$ \\
\hline
\end{tabular}

Из полученных данных таблицы 2 следует, что в группе юношей также выявлено наличие статистически значимой корреляционной связи между уровнем развития социального интеллекта и показателями: аффектомия - шизотимия (фактор $A ; r=0,61 ; p<0,05)$; премсия - харрия (фактор I; $r=-0,8 ; p<0,05)$; коэстения - зеппия (фактор $\mathrm{J} ; \mathrm{r}=-0,9 ; \mathrm{p}<0,05)$.

Выявлено также наличие прямой корреляционной связи высокой силы между уровнем развития социального интеллекта и выраженностью показателей по шкале «Интроверсия - экстраверсия», как в группе девушек $(r=0,97 ; p<0,05)$, так и в группе юношей $(r=0,96$; $\mathrm{p}<0,05)$.

Результаты корреляционного анализа меры связи между уровнем развития социального интеллекта и результатами опроса по методике «Авторская анкета» представлены в таблице 3.

При сопоставлении результатов обследования испытуемых по методикам «Тест “Социальный интеллект"» и «Авторская анкета» было установлено наличие прямой корреляционной связи между:

- уровнем развития социального интеллекта и числом социальных контактов ( $r=0,97$; $p<0,05-$ у девушек, $r=0,96 ; p<0,05-$ у юношей); 
Результаты корреляционного анализа результатов измерений по методикам «Тест “Социальный интеллект"» и «Авторская анкета» в группах девушек и юношей

\begin{tabular}{|c|c|c|c|c|c|c|c|c|c|c|}
\hline \multicolumn{11}{|c|}{ Группа девушек } \\
\hline Название & \multicolumn{10}{|c|}{ Тест «Социальный интеллект» } \\
\hline Авторская анкета & \multicolumn{2}{|c|}{ Субтест № 1} & \multicolumn{2}{|c|}{ Субтест № 2} & \multicolumn{2}{|c|}{ Субтест № 3} & \multicolumn{2}{|c|}{ Субтест № 4} & \multicolumn{2}{|c|}{$\begin{array}{l}\text { Композ. } \\
\text { оценка }\end{array}$} \\
\hline & $\mathrm{p}$ & $P$ & $\mathrm{p}$ & $\mathrm{P}$ & $\mathrm{p}$ & $\mathrm{P}$ & $\mathrm{p}$ & $P$ & $\mathrm{p}$ & $P$ \\
\hline $\begin{array}{l}\text { Степень разноо- } \\
\text { бразия контактов }\end{array}$ & 0,6 & $p<0,05$ & 0,64 & $p<0,05$ & 0,53 & $p<0,05$ & 0,57 & $p<0,05$ & 0,62 & $p<0,05$ \\
\hline Число контактов & 0,83 & $p<0,05$ & 0,91 & $p<0,05$ & 0,73 & $p<0,05$ & 0,8 & $p<0,05$ & 0,97 & $p<0,05$ \\
\hline \multicolumn{11}{|c|}{ Группа юнощей } \\
\hline $\begin{array}{l}\text { Название } \\
\text { методики }\end{array}$ & \multicolumn{10}{|c|}{ Тест «Социальный интеллект» } \\
\hline Авторская анкета & \multicolumn{2}{|c|}{ Субтест № 1} & \multicolumn{2}{|c|}{ Субтест № 2} & \multicolumn{2}{|c|}{ Субтест № 3} & \multicolumn{2}{|c|}{ Субтест № 4} & \multicolumn{2}{|c|}{$\begin{array}{l}\text { Композ. } \\
\text { оценка }\end{array}$} \\
\hline & $\mathrm{p}$ & $\mathrm{P}$ & $p$ & $P$ & $p$ & $\mathrm{P}$ & $\mathrm{p}$ & $\mathrm{P}$ & $\mathrm{p}$ & $\mathrm{P}$ \\
\hline $\begin{array}{l}\text { Степень разноо- } \\
\text { бразия контактов }\end{array}$ & 0,5 & $p<0,05$ & 0,76 & $p<0,05$ & 0,74 & $p<0,05$ & 0,63 & $p<0,05$ & 0,74 & $p<0,05$ \\
\hline Число контактов & 0,9 & $p<0,05$ & 0,87 & $p<0,05$ & 0,75 & $p<0,05$ & 0,8 & $p<0,05$ & 0,96 & $p<0,05$ \\
\hline
\end{tabular}

- уровнем развития социального интеллекта и степенью разнообразия социальных контактов ( $r=0,62 ; p<0,05-$ у девушек; $r=0,74 ; p<0,05-$ у юношей).

Таким образом, было получено статистически значимое доказательство наличия корреляционной связи:

- между уровнем развития социального интеллекта и степенью выраженности ряда личностных черт (аффектомия - шизотимия, премсия - харрия, коэстения - зеппия, интроверсия - экстраверсия), выделенных в качестве внутренних факторов развития социального интеллекта у подростков;

- между уровнем развития социального интеллекта и количественными и качественными характеристиками социального опыта индивида, выделенных в качестве внешних факторов развития социального интеллекта у подростков.

На следующем этапе исследования на основе полученных результатов была разработана программа авторского социально-психологического тренинга, направленного на развитие социального интеллекта.

Программа нацелена на формирование у участников знаний и навыков социального взаимодействия, составляющих основу социального опыта индивида, и формирования у них положительного отношения к ситуациям межличностного взаимодействия, что также должно способствовать выработке у подростков личностных мотивов приобретения социального опыта.

Программа рассчитана на 7 недель (7 занятий по 1,5 часа один раз в неделю).

Испытуемые были разделены на две группы (экспериментальную и контрольную).

После реализации авторской программы (в экспериментальной группе) в обеих группах было проведено повторное эмпирическое исследование.

В экспериментальной группе было выявлено наличие статистически значимых изменений в показателях: уровень развития социального интеллекта ( $\leq 0,01)$, аффектомия - шизотимия $(p \leq 0,01)$, премсия - харрия $(p \leq 0,05)$, число социальных контактов $(p \leq 0,01)$, степень разнообразия социальных контактов $(p \leq 0,01)$. 
В контрольной группе статистически значимых изменений между результатами первичного и повторного измерений не обнаружено.

Обсуждение. Интерпретируя результаты корреляционного исследования данных, можно сделать вывод о том, что выделенные на основе анализа научных психологических материалов по проблеме показатели действительно являются структурными компонентами конструкта «психологические механизмы формирования социального интеллекта у подростков».

Социальный интеллект - это структурный компонент общего интеллекта, который, в свою очередь, является структурным компонентом всей психики в целом [19]. Справедливо ожидать, что процесс развития социального интеллекта протекает по тем же принципам, что и развитие всей психики в целом [20]. Следовательно, под механизмами формирования социального интеллекта следует понимать функциональную взаимосвязь между уровнем развития социального интеллекта и факторами, способными оказывать влияние на данный процесс. Таким образом, в понятии «психологические механизмы формирования социального интеллекта» можно выделить структурные компоненты данного психологического явления: сам социальный интеллект (уровень его развития) и факторы, обусловливающие процесс его развития. Также можно сделать предположение, что процесс формирования социального интеллекта обусловлен воздействием двух групп факторов (внешних и внутренних).

Было установлено наличие статистической взаимосвязи между уровнем развития социального интеллекта и рядом показателей: личностные черты (аффектомия - шизотимия, премсия - харрия, коэстения - зеппия, интроверсия - экстраверсия) и характеристики социального опыта индивида (число социальных контактов, степень разнообразия социальных контактов). Таким образом, и в случае социального интеллекта можно выделить внешние (своеобразие социального опыта индивида) и внутренние (качественные характеристики выраженности черт личности) факторы, оказывающие воздействие на процесс его формирования.

Социальный опыт в отечественной психологии выделяется в качестве источника получения человеком знаний и навыков межличностного взаимодействия [4]. 0т того, как часто и с каким количеством людей общается человек, зависит объем его знаний и навыков относительно того, как должен протекать процесс общения, как интерпретировать поведенческие реакции партнеров по общению, как можно повлиять на данный процесс. Социальный интеллект - это, прежде всего, умение общаться с другими людьми. Умение определяется опытом. В связи с этим закономерно, что у испытуемых с большим числом социальных контактов наблюдается более высокий уровень развития социального интеллекта.

При анализе того, какие именно черты личности показали наличие корреляционной связи с уровнем развития социального интеллекта, становится ясно, что все они отражают ориентацию субъекта по отношению к ситуациям межличностного взаимодействия. Ориентация (или ее отсутствие) на взаимодействие с окружающими со всей очевидностью должна оказывать влияние на процесс формирования социального интеллекта. Человек может ежедневно контактировать со значительным числом людей. При этом вовсе не обязательно, что у него будут хорошо развиты навыки межличностного взаимодействия (коммуникативные навыки). Высокий уровень развития социального интеллекта наблюдается у тех испытуемых, которые демонстрируют желание общаться с другими людьми.

Установленные связи между уровнем развития социального интеллекта и внешними и внутренними факторами его развития не являются однонаправленными. Справедливо предположить, что повышение уровня развития социального интеллекта вследствие воздействия какого-либо одного фактора может привести к усилению выраженности других факторов. Например, увеличение числа доступных социальных связей обогащает социальный опыт, что способствует повышению уровня развития социального интеллекта, что, в свою очередь, приводит к выработке у подростка желания расширить свой круг общения, 
поскольку он стал гораздо увереннее себя чувствовать в ситуациях межличностного взаимодействия.

Таким образом, между структурными компонентами системы «психологические механизмы формирования социального интеллекта у подростков» существуют двусторонние функциональные связи (качественные изменения одного компонента стимулируют аналогичные изменения в других компонентах).

Анализ результатов проведения разработанной в ходе исследования программы авторского социально-психологического тренинга позволяет сделать следующий вывод: процесс формирования социального интеллекта поддается стимулирующему воздействию. У испытуемых, принявших участие в тренинговых занятиях, наблюдается статистически значимое повышение уровня развития социального интеллекта.

Среди возможных причин наблюдаемого роста сформированности социального интеллекта у подростков могут быть названы следующие.

1. Действенность эксплицитных методов научения навыкам социального взаимодействия. В механизмах функционирования социального интеллекта большую роль играют неосознаваемые процессы мышления. Поэтому могут возникнуть сомнения относительно того, возможно ли вообще вербальное научение знаниям и умениям, относящимся к сфере социального интеллекта. Человека от других представителей животного мира отличает наличие сознания (высшей формы отражения реальности). Человек в состоянии овладевать своим поведением, в том числе и мышлением. В связи с этим нет причин предполагать, что сознательное научение приемам общения с другими людьми не представляется возможным.

2. Действенность имплицитных методов научения навыкам социального взаимодействия. Качественные изменения измеряемых показателей могли быть достигнуты за счет действия механизмов имплицитного научения. В таком случае участие в тренинге просто создало благоприятную ситуацию для усвоения определенных поведенческих стратегий межличностного взаимодействия.

3. Роль мотивации в процессе научения навыкам социального взаимодействия. Сам факт участия в тренинге настраивает испытуемых на усвоение соответствующих знаний и навыков. Причина наблюдаемых изменений в таком случае заключается в желании подростков получить эти знания.

Получено подтверждение справедливости предположения о наличии двусторонней связи между уровнем развития социального интеллекта и факторами, обусловливающими процесс его формирования (внешними и внутренними), поскольку статистически значимые изменения выявлены и в отношении этих показателей (число и степень разнообразия социальных контактов, выраженность показателей по шкалам аффектомия - шизотимия, премсия - харрия, коэстения - зеппия).

Заключение. Проведенное исследование позволило доказать справедливость предположения об обусловленности процесса формирования социального интеллекта двумя группами факторов: внешними факторами (количественные и качественные характеристики социального опыта индивида) и внутренними факторами (личностные черты, отражающие отношение индивида к ситуациям межличностного взаимодействия).

В ходе исследования удалось определить специфику функционирования психологических механизмов формирования социального интеллекта у подростков. Кроме того, была доказана возможность коррекционного воздействия на процесс формирования социального интеллекта в подростковом возрасте.

\section{Список литературы}

1. Белова С.С. Социальный интеллект: сравнительный анализ методик измерения // Социальный интеллект: теория, измерения, исследования / под ред. Д.В. Люсина, Д.В. Ушакова. М.: Ин-т психологии РАН, 2004. С. 109-118. 
2. Березина Т.Н. Социальная креативность и социальный интеллект в структуре общих способностей // Психология обучения. 2016. № 2. С. 68-81.

3. Варламова Л.А. Особенности социального интеллекта современных школьников // Филологические науки. Вопросы теории и практики. 2016. № 10. С. 170-174.

4. Емельянов Ю.Н. Активное социально-психологическое обучение. Л.: Изд-во Лгу, 1985. 167 c.

5. Ильина М.И. Психологическая оценка интеллекта у детей. СПб.: Питер, 2006. 368 с.

6. Истратова 0.Н., Эксакусто Т.В. Большая книга подросткового психолога. 2-е изд. Ростов н/Д: Феникс, 2008. 636 с.; Куницына В.Н. Социальная компетентность и социальный интеллект: структура, функции, взаимоотношения // Теоретические и прикладные вопросы психологии. Вып. 1. Ч. 1. СПб., 1995. С. 48-61.

7. Лунева О.В. Теоретические основания концепции социального интеллекта // Знание. Понимание. Умение. 2011. № 3. С. 231-236.

8. Лунева 0.В., Манторова А.В. Эмоциональный интеллект: история изучения и соотношение с социальным интеллектом // Теоретические и методические вопросы исследования социального и эмоционального интеллектов. М.: Изд-во Моск. гуманит. ун-та, 2008. C. 26-31.

9. Манина К.Е. Специфика представления социального интеллекта через личностные свойства старших школьников // Успех современной науки и образования. 2016. № 2.

10. Манина К.Е. Факторы становления социального интеллекта на различных этапах онтогенеза // Общество: социология, психология, педагогика. 2016. № 12. С. 81-85.

11. Михайлова (Алёшина) Е.С. Методика исследования социального интеллекта. Руководство по использованию. СПб.: ГП «Иматон», 1996. 50 с.

12. Попова Т.В. Формирование социального интеллекта в условиях современного образования // Экономические и социально-гуманитарные исследования. 2017. № 3. С. 114-118.

13. Практикум по психологическим играм с детьми и подростками / Азарова Т.В., Барчук 0.И., Беглова Т.В., Битянова М.Р., Королева Е.Г., Пяткова О.М.; под общ. ред. М.Р. Битяновой. СПб.: Питер, 2008. 304 с.

14. Психология подростка / сост. Ю.П. Фролов. М.: Рос. пед. агентство, 1997. 526 с.

15. Райс Ф. Психология подросткового и юношеского возраста. СПб.: Питер, 2011. 816 с.

16. Рогов Е.И. Настольная книга практического психолога: в 2 ч. Ч. 1. Система работы психолога с детьми разного возраста: практ. пособие. М.: Юрайт, 2014. 412 с.

17. Социальный интеллект: теория, измерение, исследования / под ред. Д.В. Люсина, Д.В. Ушакова. М.: Ин-т психологии РАН, 2004. 176 с.

18. Социальный и эмоциональный интеллект: от процессов к измерениям / под ред. Д.В. Люсина, Д.В. Ушакова. М.: Ин-т психологии РАН, 2009. 351 с.

19. Ушаков Д.В. Психология интеллекта и одаренности. М.: Ин-т психологии РАН, 2011. 464 С. 20. Холодная М.А. Психология интеллекта. Парадоксы исследования. М.: Юрайт, 2019. 334 с.

\section{References}

1. Belova S.S. Social'nyj intellekt: sravnitel'nyj analiz metodik izmereniya // Social'nyj intellekt: teoriya, izmereniya, issledovaniya / pod red. D.V. Lyusina, D.V. Ushakova. M.: In-t psikhologii RAN, 2004. S. 109-118.

2. Berezina T.N. Social'naya kreativnost' i social'nyj intellekt $v$ strukture obshchikh sposobnostej // Psikhologiya obucheniya. 2016. № 2. S. 68-81.

3. Varlamova L.A. Osobennosti social'nogo intellekta sovremennykh shkol'nikov // Filologicheskie nauki. Voprosy teorii i praktiki. 2016. № 10. S. 170-174.

4. Emel'yanov Yu.N. Aktivnoe social'no-psikhologicheskoe obuchenie. L.: Izd-vo LGU, 1985. $167 \mathrm{~s}$.

5. Il'ina M.I. Psikhologicheskaya ocenka intellekta u detej. SPb.: Piter, 2006. 368 s.

6. Istratova 0.N., Eksakusto T.V. Bol'shaya kniga podrostkovogo psikhologa. 2-e izd. Rostov n/D: Feniks, 2008. 636 s.; Kunicyna V.N. Social'naya kompetentnost' i social'nyj intellekt: struktura, funkcii, vzaimootnosheniya // Teoreticheskie i prikladnye voprosy psikhologii. Vyp. 1. Ch. 1. SPb., 1995. S. 48-61.

7. Luneva 0.V. Teoreticheskie osnovaniya koncepcii social'nogo intellekta // Znanie. Ponimanie. Umenie. 2011. № 3. S. 231-236.

8. Luneva 0.V., Mantorova A.V. Emocional'nyj intellekt: istoriya izucheniya i sootnoshenie s social'nym intellektom // Teoreticheskie i metodicheskie voprosy issledovaniya social'nogo i emocional'nogo intellektov. M.: Izd-vo Mosk. gumanit. un-ta, 2008. S. 26-31. 
9. Manina K.E. Specifika predstavleniya social'nogo intellekta cherez lichnostnye svojstva starshikh shkol'nikov // Uspekh sovremennoj nauki i obrazovaniya. 2016. № 2.

10. Manina K.E. Faktory stanovleniya social'nogo intellekta na razlichnykh etapakh ontogeneza // Obshchestvo: sociologiya, psikhologiya, pedagogika. 2016. № 12. S. 81-85.

11. Mikhajlova (Alyoshina) E.S. Metodika issledovaniya social'nogo intellekta. Rukovodstvo po ispol'zovaniyu. SPb.: GP «Imaton», 1996. $50 \mathrm{~s}$.

12. Popova T.V. Formirovanie social'nogo intellekta v usloviyakh sovremennogo obrazovaniya // Ekonomicheskie i social'no-gumanitarnye issledovaniya. 2017. № 3. S. 114-118.

13. Praktikum po psikhologicheskim igram s det'mi i podrostkami / Azarova T.V., Barchuk 0.I., Beglova T.V., Bityanova M.R., Koroleva E.G., Pyatkova 0.M.; pod obshch. red. M.R. Bityanovoj. SPb.: Piter, 2008. 304 s.

14. Psikhologiya podrostka / sost. Yu.P. Frolov. M.: Ros. ped. agentstvo, 1997. $526 \mathrm{~s}$.

15. Rajs F. Psikhologiya podrostkovogo i yunosheskogo vozrasta. SPb.: Piter, 2011. $816 \mathrm{s.}$

16. Rogov E.I. Nastol'naya kniga prakticheskogo psikhologa: v 2 ch. Ch. 1 . Sistema raboty psikhologa s det'mi raznogo vozrasta: prakt. posobie. M.: Yurajt, 2014. $412 \mathrm{~s}$.

17. Social'nyj intellekt: teoriya, izmerenie, issledovaniya / pod red. D.V. Lyusina, D.V. Ushakova. M.: In-t psikhologii RAN, 2004. $176 \mathrm{~s}$.

18. Social'nyj i emocional'nyj intellekt: ot processov $\mathrm{k}$ izmereniyam / pod red. D.V. Lyusina, D.V. Ushakova. M.: In-t psikhologii RAN, 2009. $351 \mathrm{s.}$

19. Ushakov D.V. Psikhologiya intellekta i odarennosti. M.: In-t psikhologii RAN, 2011. $464 \mathrm{~s}$.

20. Kholodnaya M.A. Psikhologiya intellekta. Paradoksy issledovaniya. M.: Yurajt, 2019. 334 s.

\section{Библиографическое описание статьи / Reference to article}

Белякова Н.В., Хасанова Д.Р. Механизмы формирования социального интеллекта в подростковом возрасте // Ученые записки Российского государственного социального университета. T. 19. 2020. № 1 (154). C. 28-36. DOI: 10.17922/2071-5323-2020-19-1-28-36 (Библиографическое описание согласно российским стандартам).

Belyakova N.V., Khasanova D.R. Mekhanizmy formirovaniya social'nogo intellekta $\checkmark$ podrostkovom vozraste // Uchenye zapiski Rossijskogo gosudarstvennogo social'nogo universiteta. T. 19. 2020. № 1 (154). S. 28-36. D0I: 10.17922/2071-5323-2020-19-1-28-36 (Reference in Roman script).

Belyakova, N.V. \& Khasanova, D.R. (2020) The Mechanisms of Formation of Social Intelligence in Adolescence, Scientific Notes of Russian State Social University. Vol. 19. No. 1 (154). P. 2836. DOI: 10.17922/2071-5323-2020-19-1-28-36 (International bibliographic description). 


\section{Е.А. Петрова,}

д-р психол. наук, профессор, декан факультета психологии,

заведующая кафедрой социальной, общей и клинической психологии,

Российский государственный социальный университет, Москва.

E.A. Petrova,

doctor of psychological sciences, professor, dean of the faculty of psychology,

head of the department of social, general and clinical psychology,

Russian State Social University, Moscow.

E-mail: petrova-sorina@yandex.ru

\section{М.А. Коваленко,}

аспирант, Российский государственный социальный университет, Москва.

M.A. Kovalenko,

postgraduate student, Russian State Social University, Moscow.

E-mail: avestamv@mail.ru

\section{M.С. Сисошвили,}

аспирант, Российский государственный социальный университет, Москва.

M.S. Sisoshvili,

postgraduate student, Russian State Social University, Moscow.

E-mail: zaizak555@yandex.ru

\section{Психологическая наблюдательность в деятельности профайлера}

\section{Psychological Observation in Profiler Activity}

Дата поступления

11.12.2019

\author{
Дата препринта
}

28.02.2020
Дата публикации

30.03.2020

Аннотация: в статье представлены результаты эмпирического исследования психологической наблюдательности профайлеров в целях выявления уровня их компетенции. Для исследования был разработан авторский опросник, включающий в себя 112 вопросов. Представлены результаты исследования 188 специалистов службы транспортной безопасности, выявлены зоны наблюдения, представляющие наибольшие сложности в профессиональной деятельности профайлеров, сделан вывод о необходимости развития их компетенции, в том числе специально организованных видеотренингов.

Annotation: the article presents the results of empirical research of psychological observation of profilers in order to identify the level of their competence. The author's questionnaire including 112 questions was developed for the research. The results of the study of 188 specialists of the transport security service, identified areas of observation, representing the greatest difficulties in the professional activities of profilers, concluded the need to develop their competence, including specially organized video training.

Ключевые слова: профайлинг, психологическая наблюдательность, транспортная безопасность, профайлер, терроризм, невербальное поведение, транспортная безопасность.

Key words: profiling, psychological observation, transport security, profiler, terrorism, nonverbal behavior.

Введение. В профессиональной сфере «человек - человек» наблюдательность рассматривается как профессионально важное качество, о чем писал еще классик отечественной психологии труда Е.А. Климов. 
Наблюдательность - это умение фиксировать максимальное количество деталей при первом взгляде. В свою очередь, умение - это способность делать что-нибудь, основанное на знании, опытности, навыке, где навык выступает как привычная реакция (человека или животного) на какое-нибудь раздражение, возникающая в результате многократного опыта $[12 ; 15]$. К числу навыков можно причислить понимание и перцептивное предвидение поведения других людей в ситуациях недлительного или единичного контакта, которые во многом зависят от развития наблюдательности [7].

В процессе межличностного взаимодействия в деятельности профайлера имеет место восприятие социальных объектов. В данном случае речь идет о наблюдении, которое включает в себя широкий спектр (диапазон) различных видов перцепции от простого восприятия внешности, отдельных черт личности другого к глубокому проникновению в его внутренний мир [14]. Таким образом, наблюдательность выступает в качестве специфической сферы перцепции и определяется как восприятие, понимание и оценка личностью или группой людей самих себя, групп или социальных обществ, а также связи между ними [1].

Впервые использование термина «наблюдение» было предложено Дж. Брунером. Термин использовался для обозначения факта детерминации перцептивных процессов социальными фактами [4]. Через некоторое время он приобрел другое значение. Под социальной перцепцией стали понимать специфическую область восприятия социальных объектов, в число которых включались личность, группа, более широкие сообщества и общество в целом [2].

Социально-психологические аспекты проблемы наблюдения стали разрабатываться прежде всего в рамках различных когнитивных теорий [18]. Именно в когнитивизме были сформированы исходные принципы исследования наблюдения и вместе с тем возникли определенные методологические ограничения, присущие этой традиции [10].

Дадим некоторые пояснения: элементы, из которых состоит познавательная сфера, образуют целостную когнитивную структуру. Именно благодаря этому отражение характеризуется целостностью. В результате изменения хотя бы одного признака впечатление о человеке приводит к перестройке всей его структуры [1]. Поэтому присутствие противоречивой информации об объекте познания вызывает у субъекта желание согласовать ее, а если это не удается, то и вообще избавиться от нее, ведь для когнитивной структуры характерно стремление сбалансированности, а любое несогласование ее элементов является источником активности субъекта [20]. На следующих этапах исследования был введен социальный контекст - начали изучаться ситуационные компоненты, которые влияют на процесс построения образа [5].

Основанием для всех исследований социального познания с точки зрения когнитивной теории (на каком бы уровне обобщения его не рассматривали) является представление о нем как о процессе категоризации, который заключается в том, что каждый новый объект восприятия относится к некоторому классу подобных и уже известных объектов категоризации $[11 ; 17 ; 20]$.

Такой подход позволяет учитывать субъективность и личностный характер процессов наблюдения, выяснить влияние на процесс и результат познания социальной реальности как характеристик информации, так и особенностей субъекта, осуществляющего ее переработку, а также учесть социально-психологический контекст.

В работах Л.А. Регуш описаны универсальные особенности профессиональной наблюдательности, которые применимы и к деятельности профайлеров.

Первая специфическая особенность наблюдательности в профессиях типа «человек - человек» состоит в том, что нужно во внешнем поведении или в самой внешности человека увидеть его внутренние, психические, состояния или свойства. Профайлер должен считывать прежде всего специфику состояния человека и анализировать его возможные последствия.

Вторая особенность наблюдательности заключается в необходимости дифференцировать признаки, через которые человек выражает себя вовне. Необходимо развитие как 
абсолютной, так и относительной чувствительности именно к этим признакам. В деятельности профайлера в первую очередь это - информация о самоподаче образа «Я» человека, демонстрации своей групповой идентичности.

Третья особенность наблюдательности связана с профессиональным интересом, который определяется задачами текущей деятельности профайлера. Данные наблюдения включаются в нее и в то же время, исходя из особенностей профессиональных знаний, могут быть поняты и истолкованы.

Четвертая особенность наблюдательности определяется тем, что содержание деятельности в профайлинге предполагает взаимодействие людей. Можно сказать, что наблюдательность в этом случае предполагает не только перцептивные и понятийные качества наблюдателя, но и эмпатийные. Особая задача профайлера в современной ситуации - выявление лиц, представляющих социальную угрозу [13].

Кроме того, наблюдательность может характеризоваться как сенсорное свойство организации личности, а также ее социальной перцепции, которая включает в себя следующие элементы: перцептивный, понятийный, эмпатийный и прогностический компоненты [6].

В структуру психологической наблюдательности входят два взаимодополняющих элемента - психологическое наблюдение и психологическое знание, в связи с чем указывается, что психологическое наблюдение является одним из важнейших способов получения и пополнения психологического знания. Одних психологических знаний не всегда хватает для развития психологической наблюдательности - для достижения успеха личности требуется также овладеть определенными навыками и умениями [8].

Социально-психологическая наблюдательность проявляется в ситуациях взаимоотношения личностей, их адекватном познании, прогнозировании их поведения и с учетом межличностных отношений [9].

Стратегия национальной безопасности Российской Федерации к основным угрозами ее безопасности относит деятельность разного рода террористических и экстремистских организаций и группировок, использующих националистическую и религиозно-экстремистскую идеологию в целях дестабилизации социальной ситуации в стране [16, с. 322, 707].

Возникает вопрос о степени развития психологической наблюдательности у специалистов по профайлингу, а также потребности повышения их квалификации в сфере выявления рисков социальной угрозы со стороны данных групп.

Отдельной проблемой является поиск путей развития психологической наблюдательности у профайлеров, повышение их компетенции. На практике отсутствуют разнообразные методики, тренажеры, позволяющие совершенствовать целенаправленную поисковую работу, направленную на выявление лиц, склонных к совершению преступлений террористической направленности на объектах транспортного комплекса. Это, в свою очередь, обусловливает необходимость разработки и внедрения принципиально новых организационных и тактических форм противодействия террористическим проявлениям с максимальным учетом уровня психологической наблюдательности и компетенции сотрудников.

Методика. В целях выявления уровня психологической наблюдательности и профессиональной компетенции профайлеров, работающих в сфере обеспечения безопасности на транспорте, нами был разработан опросник, включающий в себя 112 вопросов. Опросник создавался нами с помощью экспертной группы специалистов-профайлеров и профессиональных психологов, специализирующихся по проблемам невербальной коммуникации. Кроме определения компетенции опросник содержит открытые вопросы, предполагающие определение реальных признаков и показателей, на которые опираются сотрудники в своей работе. Часть вопросов направлена на выявление степени осознания, развития своей психологической наблюдательности, понимания необходимости дальнейшего развития данного качества, а также необходимости специального обучения технологиям и алгоритмам обнаружения в пассажиропотоке лиц в группе риска. 
Опросник направлен на выявление тактических особенностей в деятельности лиц, задействованных в пассажиропотоке. С помощью данной методики выявляются реальные индикации, с помощью которых сотрудники службы транспортной безопасности (далее - СБ) определяют лиц, представляющих оперативный интерес. Это позволяет более реалистично видеть картину их работы. В данном опросе содержаться конкретные направления, задачи и алгоритмы действий, которые на практике применяют сотрудники СБ, что позволяет определить круг их компетенций.

Опрос проведен в период с февраля по май 2018 года. Нами была взята выборка из 188 специалистов служб безопасности, стаж работы которых составляет от одного года до 10 лет. В большинстве сотрудники имеют среднее специальное образование и, в меньшей степени, высшее образование. Данная выборка ежедневно работает в пассажиропотоке в целях выявления лиц, представляющих оперативный интерес.

Результаты. В ходе обработки опроса нами было выявлено, что большинство специалистов-профайлеров (66\%) считают, что состояние нормативно-правовой базы в решении задач по выявлению и задержанию в пассажиропотоке лиц, склонных к совершению преступлений различной категории, находится в оптимальном состоянии и не требует доработок по контактному взаимодействию сотрудника СБ с предполагаемым носителем протеррористической активности. Большинство сотрудников служб безопасности считают, что обладают достаточными знаниями для выявления в пассажиропотоке лица, замышляющего теракт (64\%).

Однако в то же время нами были получены данные, которые указывают на то, что специалистам данной направленности необходимы разработка памятки в области выявления потенциально опасных лиц на транспорте, по выявлению в пассажиропотоке носителей протеррористической активности (64\%), а также выработка четкого алгоритма действий для обнаружения в пассажиропотоке лиц, подозреваемых в совершении или намерении реализовать теракт (60\%).

Средний уровень психологических знаний по результатам опросника составляет 64\%. Основными источниками получения психологических данных являются: инструкция, Интернет и СМИ. Основными известными психологическими особенностями носителей протеррористической активности, по мнению сотрудников МВД, являются: поведение - 47\%, габитус - 6\%, костюм - 4\%, кинесика - 5\%, вербальная составляющая - 3\%, эмоции $3 \%$, реакция на полицию - $2 \%$.

В ходе обработки данного опросника нами был проведен контент-анализ ответов, где были выделены следующие категории: кинесика, костюм, габитус, вербальная составляющая, поведение, реакция на полицию, запах, эмоции.

Основными визуально значимыми индикациями человека, намеревающегося совершить теракт, по мнению сотрудников службы безопасности, являются: поведение - 28\%, костюм $21 \%$, габитус $-11 \%$, кинесика - $2 \%$, вербальная составляющая - $3 \%$, эмоции - $3 \%$, реакция на полицию - 6\%. В целом большинство сотрудников имеют представление о значимых индикациях, но в то же время определенный процент опрошенных отмечали необходимость и значимость повышения квалификации в понимании того, на что обращать внимание в первую очередь, как классифицировать и интерпретировать полученные данные.

Основными поведенческими особенностями человека, намеревающегося совершить теракт, по мнению $60 \%$ сотрудников служб безопасности, являются: поведение - 32\%, кинесика - 7\%, габитус - 6\%, костюм - 5\%, вербальная составляющая - $2 \%$, реакция на полицию $5 \%$, эмоции - 3\%. На основании полученных данных мы можем сказать, что очень маленький процент респондентов понимают вообще, что такое поведенческие особенности человека, соответственно, большинство из них не могут определить данный критерий человека.

Основными аудиально значимыми признаками человека, намеревающегося совершить теракт, по мнению сотрудников СБ (ответили 38\%), являются: вербальная составляющая $19 \%$, поведение $13 \%$, эмоции- $3 \%$, костюм - $2 \%$, габитус - 1\%. С помощью абсолютного боль- 
шинства респондентов мы видим, насколько отсутствует понимание вообще самого понятия «аудиально значимый признак»!

Основные невербальные индикации человека, намеревающегося совершить теракт, отметили всего $32 \%$ опрошенных, упомянув: поведение - $12 \%$, кинесику $-10 \%$, габитус - $7 \%$, костюм - 1\%, вербальную составляющую - 1\%, эмоции - 1\%. Нет также понимания невербальных индикаторов человека.

Основными внешними признаками (индикации) лиц, замышляющих теракт, по мнению сотрудников СБ (51\%), являются: костюм - 20\%, поведение - $18 \%$, кинесика - 3\%, габитус $6 \%$, вербальная составляющая - $3 \%$, реакция на полицию - $1 \%$. В данном вопросе мнения разделились пополам, но тот факт, что 49\% затрудняются с ответом, наводит на размышление о подготовленности специалистов.

Фокус-зоны тела человека, на которые сотрудники СБ в первую очередь обращают внимание, в процессе выявления лиц, представляющих оперативный интерес: 1) лицо и его особенности; 2) одежда; 3) багаж. Данная оценка основана: на интуиции - 26\%; информации в Интернете, СМИ - 20\%; специальной литературе - 19\%; опыте - $17 \%$; приказе (инструкции) - 18\%. Здесь мы видим, что каждый для себя выбирает источник либо личностные характеристики, которые позволяют определять фокус-зоны. Важно отметить, что изучение специальной литературы не является первостепенным.

Большинство сотрудников СБ считают, что по особенностям поведения можно вычислить в пассажиропотоке лицо, замышляющее теракт. Подтвердили это утверждение $70 \%$ респондентов, затруднились ответить $24 \%$, отрицательно ответили $6 \%$. В данном вопросе важны именно $24 \%$ опрошенных, так как именно эти люди обеспечивают безопасность, не понимая основных аспектов данной области.

На вопрос «0пишите сложности общения с лицами, схожими по описанию внешности на лица, проходящие по ориентировкам» $50 \%$ специалистов ответили следующим образом: не испытывают трудностей - 36\%, поведение указали 7\%, габитус - 3\%, вербальная составляющая - 4\% респондентов. Данные цифры дают понять, что специалисты в общем не уделяют внимания процессу общения, не делают на этом должный акцент.

На вопрос «0пишите возможные сложности общения с лицами, замышляющими теракт» всего 45\% специалистов службы безопасности ответили следующим образом: затруднились ответить 55\%, не испытывают трудностей 32\%, поведение указали 9\%, вербальную составляющую отметили 4\%. При данных ответах мы видим ту же проблему, что специалисты в принципе не понимают сути вопроса и не могут классифицировать возможные сложности.

На вопрос об основных особенностях поведения представителей деструктивных религиозных организаций (сектантов) ответили 40\% респондентов: в своих ответах сотрудники СБ указали: поведение - 21\%, вербальную составляющую - 10\%, костюм - 8\%, кинесику - $1 \%$.

На вопрос об основных внешних признаках (индикациях), присущих представителям деструктивных религиозных организаций (сектантов), смогли ответить всего 39\% человек: по мнению сотрудников СБ, ими являются: костюм - 11\%, поведение - 9\%, вербальная составляющая $-7 \%$, габитус $-2 \%$.

На вопрос «0пишите сложности общения с представителями деструктивных религиозных организаций» только 20\% сотрудников СБ ответили, что: не испытывают трудностей - 12\%, считают главной сложностью поведение - 6\%, вербальную составляющую - $2 \%$.

На вопрос «0пишите сложности общения с представителями молодежных неформальных организаций» только 41\% сотрудников СБ ответили следующим образом: не испытывают трудностей 31\%, поведение указали 9\%, эмоции - $1 \%$. Необходимо отметить, что больше половины сотрудников службы безопасности не понимают, в чем состоят особенности поведения этих граждан, их внешние признаки, и у них есть проблемы в общении с данной категорией граждан. 
Основными особенностями поведения представителей молодежных экстремистских организаций (скинхедов и др.), по мнению 54\% сотрудников СБ, являются: поведение - $26 \%$, костюм - 21\%, вербальная составляющая - 5\%, габитус - $2 \%$.

Основными внешними признаками (индикациями), присущими представителям молодежных экстремистских организаций (скинхедов и др.), по мнению 45\% сотрудников СБ, указаны: костюм - 32\%, поведение - 9\%, габитус - 1\%, вербальная составляющая - $3 \%$.

На вопрос «Опишите сложности общения с представителями молодежных экстремистских организаций» всего $39 \%$ сотрудников СБ ответили на этот вопрос следующим образом: не испытывают трудностей 30\%, поведение указали 7\%, вербальную составляющую - $2 \%$. В определении данной категории людей в процентном соотношении мы видим, что сотрудники СБ очень плохо определяют значимые критерии в поведении и внешности, а также испытывают сложности в общении.

Обсуждение. В ходе обработки данных опроса было выявлено, что большинство специалистов-профайлеров $(51,2 \%)$ не осознают тех проблем, которые возникают в их деятельности, в связи с недостаточной подготовкой их к обнаружению в пассажиропотоке лиц, представляющих оперативный интерес. Это сказывается в большом проценте ответов «затрудняюсь ответить» на вопросы о возможном совершенствовании нормативно-законодательной базы в решении этих задач, а также в ответах на прямые вопросы о необходимости дополнительных инструкций-памяток, а также описаний четких алгоритмов действий при обнаружении в пассажиропотоке лиц из группы риска.

Самооценка собственной подготовленности и знаний данного контингента испытуемых также оказывается весьма неадекватной, хотя 64\% отметили, что имеют средний и достаточный уровень психологических знаний, однако ответы на более глубокие вопросы выявляют противоречия в знаниях специалистов службы безопасности и показывают разную степень глубины тех проблем, которые связаны с недостаточностью их подготовки. На большинство вопросов, заданных сотрудникам СБ, максимально распространенным ответом было «затрудняюсь ответить», что показывает невозможность сформулировать испытуемыми те реальные знания, которые у них есть. Наибольшее затруднение при этом вызывали вопросы, связанные с общением с представителями деструктивных религиозных организаций (80\% затруднялись ответить, каким образом обнаруживать, по каким признакам судить $(71 \%)$ и каким образом общаться (80\%)). Возникают также сложности, связанные с невербальной индикацией представителей террористических организаций: 68\% затруднялись ответить на этот вопрос и у $62 \%$ респондентов вызвало затруднение определение аудиальнозначимых признаков, то есть испытуемые не знают специфики речи, особенностей манеры общения людей, которые относятся к протеррористическим организациям. Если говорить об экстремистских организациях, то они, а также молодежные неформальные организации не дифференцируются нашими испытуемыми: 55\% сотрудников СБ затруднились определить их по внешним признакам, 46\% - по основным особенностям поведения, 59\% затрудняются ответить о специфике общения с представителями данных организаций. Большинство из отвечающих испытывают названные сложности. Испытывают их и сотрудники СБ в вопросах взаимодействия и общения с лицами, замышляющими теракт: 55\% опрошенных затрудняются ответить и не знают, каковы эти сложности и как их надо разрешать.

В целом мы видим, что трудности, которые возникают при определении и построении общения с лицами из группы риска, связаны с разной степенью компетентности сотрудников в некоторых признаках, таких, например, как визуально воспринимаемые индикаторы, которых не видят 27\% респондентов, тогда как поведенческие индикаторы вызывают затруднения у $40 \%$, аудиальные - у $62 \%$ опрошенных сотрудников, то есть в целом невербальная индикация вызывает затруднение у $68 \%$ работников СБ. Выявление поведенческих особенностей лиц, склонных к совершению преступлений террористической направленности, у $40 \%$ сотрудников также не имеет четкой ясности. 
Заключение. В целом, анализируя ответы сотрудников СБ, непосредственно работающих в пассажиропотоке, можно прийти к однозначному выводу, что уровень психологической наблюдательности специалистов крайне низкий, особые сложности возникают при интерпретации внешних признаков отдельных паттернов поведения. На все вопросы, касающиеся специфики построения общения с определенными категориями граждан и возникающих в связи с этим проблем, более половины опрошенных затруднились ответить. Это говорит о том, что, во-первых, уровень базовой компетенции очень низкий или отсутствует совсем. Во-вторых, мы видим не только полное отсутствие специальных знаний, необходимых непосредственно для выполнения служебных обязанностей, но и отсутствие внимательности, низкий уровень наблюдательности, слабую выраженность соответствующих навыков наблюдения. А ведь это так важно для определения потенциально опасного пассажира, посетителя, от этого во многом зависит безопасность в местах массового скопления людей. Резюмируя сказанное, мы считаем необходимым проведение специального обучения профайлеров, а также повышение их квалификации, постоянное проведение обучающих тренингов, в том числе видеотренингов, для того, чтобы специалисты находились в профессиональном тонусе и постоянно тренировали и улучшали свои навыки. Только благодаря такому подходу мы сможем повышать эффективность профессиональной деятельности профайлеров в местах массового скопления людей на транспорте.

\section{Список литературы}

1. Андреева Г.М. К построению теоретической схемы исследования социальной перцепции // Вопросы психологии. 2003. № 3. С. 3-14.

2. Андреева Г.М., Яноушек Я. Общение и оптимизация совместной деятельности. М.: Изд-во Моск. ун-та, 1998. 302 с.

3. Андреева Г.М. Психология социального познания: учеб. пособие для студ. психол. и пед. спец. вузов. 3-е изд.; перераб и доп. М.: Аспект Пресс, 2008. 288 с.

4. Брунер Дж. Психология познания. За пределами непосредственной информации / пер. С англ. М.: Прогресс, 2004. 352с.

5. Кальней М.С. Противоречия в применении картезианского метода к социальному познанию // Экономические и социально-гуманитарные исследования. 2015. № 2 (6). С. 62-65.

6. Кислова Г.И. Развитие наблюдательности в процессе профессиональной подготовки будущих учителей: дис. ... канд. психол. наук. СПб., 1995. 124 с.

7. Климов Е.А. Психология профессионального самоопределения. М.: Academia, 2012. 253 с.

8. Кулькова И.В. Развитие психологической наблюдательности кадров государственной службы: автореф. дис ... канд. психол. наук. М., 1996. 35 с.

9. Лабунская В.А. Экспрессия человека: общение и межличностное познание. Ростов н/Д, 2001. 432 с.

10. Межличностное восприятие в группе / под ред. Г.М. Андреевой, А.И. Донцова. М.: Издво Моск. ун-та, 1991. 295 с.; Психология межличностного познания: сб. ст. / под ред. А.А. Бодалева. М.: Педагогика, 1991. 223 с.

11. Минигалиева М.Р. Когнитивные схемы и эвристические процессы в социальном познании // Мир психологии. 1999. № 3. С. 40-52.

12. Психологический словарь: словарь / под ред. А.В. Петровского, М.Г. Ярошевского. 3-е изд., испр. и доп. М.: Политиздат, 2008. 494 с.

13. Регуш Л.А. Практикум по наблюдению и наблюдательности. 3-е изд., перераб. и доп. СПб.: Питер, 2016. 208 с.

14. Розен Г.Я. Психология познания как самостоятельное направление исследований // Зарубежные исследования по психологии познания: сб. аналит. обзоров. М.: Универс групп, 2010. С. $13-61$.

15. Указ Президента Российской Федерации от 31 декабря 2015 г. № 683 «0 Стратегии национальной безопасности Российской Федерации».

16. Ушаков Д.Н. Толковый словарь современного русского языка. М., 2016.

17. Фидлер К. Переработка социальной информации для суждений и решений // Перспективы социальной психологии / пер. с англ. М.: Эксмо-Пресс, 2003. С. 156-187.

18. Шихирев П.Н. Исследования стереотипа в американской социальной науке // Вопросы философии. 2004. № 6. С. 159-183. 
19. Davis L.L. Social salience: What we notice first about a person // Perceptual and Motor Skills. Vol. 78. 2005. No. 2.

20. Zarate M.A., Smith E.R. Person categorization and stereotyping // Social Cognition. Vol. 12. 2009. No. 3. P. $161-185$.

\section{References}

1. Andreeva G.M. K postroeniyu teoreticheskoj skhemy issledovaniya social'noj percepcii // Voprosy psikhologii. 2003. № 3. S. 3-14.

2. Andreeva G.M., Yanoushek Ya. Obshchenie i optimizaciya sovmestnoj deyatel'nosti. M.: Izd-vo Mosk. un-ta, 1998. $302 \mathrm{~s}$.

3. Andreeva G.M. Psikhologiya social'nogo poznaniya: ucheb. posobie dlya stud. psikhol. i ped. spec. vuzov. 3-e izd.; pererab i dop. M.: Aspekt Press, 2008. 288 s.

4. Bruner Dzh. Psikhologiya poznaniya. Za predelami neposredstvennoj informacii / per. s angl. M.: Progress, 2004. 352s.

5. Kal'nej M.S. Protivorechiya v primenenii kartezianskogo metoda k social'nomu poznaniyu // Ekonomicheskie i social'no-gumanitarnye issledovaniya. 2015. № 2 (6). S. 62-65.

6. Kislova G.I. Razvitie nablyudatel'nosti $\vee$ processe professional'noj podgotovki budushchikh uchitelej: dis. ... kand. psikhol. nauk. SPb., 1995. 124 s.

7. Klimov E.A. Psikhologiya professional'nogo samoopredeleniya. M.: Academia, 2012. $253 \mathrm{~s}$.

8. Kul'kova I.V. Razvitie psikhologicheskoj nablyudatel'nosti kadrov gosudarstvennoj sluzhby: avtoref. dis ... kand. psikhol. nauk. M., 1996. 35 s.

9. Labunskaya V.A. Ekspressiya cheloveka: obshchenie i mezhlichnostnoe poznanie. Rostov n/D, 2001. $432 \mathrm{~s}$.

10. Mezhlichnostnoe vospriyatie $v$ gruppe / pod red. G.M. Andreevoj, A.I. Doncova. M.: Izd-vo Mosk. un-ta, 1991. 295 s.; Psikhologiya mezhlichnostnogo poznaniya: sb. st. / pod red. A.A. Bodaleva. M.: Pedagogika, 1991. 223 s.

11. Minigalieva M.R. Kognitivnye skhemy i evristicheskie processy v social'nom poznanii // Mir psikhologii. 1999. № 3. S. 40-52.

12. Psikhologicheskij slovar': slovar' / pod red. A.V. Petrovskogo, M.G. Yaroshevskogo. 3-e izd., ispr. i dop. M.: Politizdat, 2008. 494 s.

13. Regush L.A. Praktikum po nablyudeniyu i nablyudatel'nosti. 3-e izd., pererab. i dop. SPb.: Piter, 2016. 208 s.

14. Rozen G.Ya. Psikhologiya poznaniya kak samostoyatel'noe napravlenie issledovanij // Zarubezhnye issledovaniya po psikhologii poznaniya: sb. analit. obzorov. M.: Univers grupp, 2010. S. 13-61.

15. Ukaz Prezidenta Rossijskoj Federacii ot 31 dekabrya 2015 g. № 683 «0 Strategii nacional'noj bezopasnosti Rossijskoj Federacii».

16. Ushakov D.N. Tolkovyj slovar' sovremennogo russkogo yazyka. M., 2016.

17. Fidler K. Pererabotka social'noj informacii dlya suzhdenij i reshenij // Perspektivy social'noj psikhologii / per. s angl. M.: Eksmo-Press, 2003. S. 156-187.

18. Shikhirev P.N. Issledovaniya stereotipa $v$ amerikanskoj social'noj nauke // Voprosy filosofii. 2004. № 6. S. 159-183.

19. Davis L.L. Social salience: What we notice first about a person // Perceptual and Motor Skills. Vol. 78. 2005. No. 2.

20. Zarate M.A., Smith E.R. Person categorization and stereotyping // Social Cognition. Vol. 12. 2009. No. 3. P. 161-185.

\section{Библиографическое описание статьи / Reference to article}

Петрова Е.А., Коваленко М.А., Сисошвили М.С. Психологическая наблюдательность в деятельности профайлера // Ученые записки Российского государственного социального университета. T. 19. 2020. № 1 (154). C. 37-44. DOI: 10.17922/2071-5323-2020-19-1-3744 (Библиографическое описание согласно российским стандартам).

Petrova E.A., Kovalenko M.A., Sisoshvili M.S. Psikhologicheskaya nablyudatel'nost' $\checkmark$ deyatel'nosti profajlera // Uchenye zapiski Rossijskogo gosudarstvennogo social'nogo universiteta. T. 19. 2020. № 1 (154). S. 37-44. DOI: 10.17922/2071-5323-2020-19-1-37-44 (Reference in Roman script).

Petrova, E.A., Kovalenko, M.A. \& Sisoshvili, M.S. (2020) Psychological Observation in Profiler Activity, Scientific Notes of Russian State Social University. Vol. 19. No. 1 (154). P. 37-44. D0I: 10.17922/2071-5323-2020-19-1-37-44 (International bibliographic description). 


\title{
О.Б. Полякова,
}

канд. психол. наук, доцент, доцент кафедры социальной, общей

и клинической психологии, Российский государственный социальный университет, Москва; доцент кафедры педагогики и психологии, Открытый гуманитарно-экономический университет, Москва.

O.B. Polyakova,

candidate of psychological sciences, associate professor, associate professor

of the department of social, general and clinical psychology, Russian State

Social University, Moscow; associate professor of the department of pedagogy

and psychology, Open Humanitarian and Economic University, Moscow.

E-mail:pob-70@mail.ru

\section{Специфика управленческого потенциала психологов с профессиональными деформациями}

\author{
The Specifics of the Managerial Potential of Psychologists \\ with Professional Deformations
}

$\begin{array}{ccc}\text { Дата поступления } & \text { Дата препринта } & \text { Дата публикации } \\ 13.12 .2019 & 28.02 .2020 & 30.03 .2020\end{array}$

Аннотация: в статье определена специфика управленческого потенциала психологов с профессиональными деформациями, характеризующегося высокой степенью авторитарного и либерального стилей руководства, безразличного, инструктирующего, консервативного, лидерского, монологичного и серьезного управленческих стилей, управленческой деятельности воспитателя, кадровика, контролера и штабного работника; средней выраженностью агрессивного и эмоционального управленческих стилей, демократического стиля руководства, управленческой деятельности общественника и снабженца, эффективного руководства; низким уровнем ведомого, внушающего, демократического, диалогичного, доброжелательного, рационального, эвристичного, эмпатийного и юмористичного управленческих стилей, управленческой деятельности дипломата, инноватора, мыслителя и организатора.

Annotation: in the article the specificity of the managerial potential of psychologists with professional deformations is defined, characterized by a high degree of authoritarian and liberal leadership styles, indifferent, instructing, conservative, leadership, monologous and serious managerial styles, managerial activities of the educator, personnel officer, supervisor and staff employee, average severity of aggressive and emotional managerial styles, a democratic style of leadership, managerial activity of a social activist and procurement, effective leadership; low level of driven, inspiring, democratic, dialogical, benevolent, rational, heuristic, empathic and humorous management styles, management activities of a diplomat, innovator, thinker and organizer.

Ключевые слова: деперсонализация, профессиональные деформации, психологи, редукция личных достижений, стиль руководства, управленческая деятельность, управленческий потенциал, управленческий стиль, эмоциональное истощение.

Key words: depersonalization, professional deformations, psychologists, reduction of personal achievements, leadership style, managerial activity, managerial potential, managerial style, emotional exhaustion.

Введение. Проблема профессиональных деформаций представителей социономических профессий (психологов, педагогов, медиков, социальных работников и др.) - это 
актуальная, основная тематика научных исследований по психологии труда и психологии личности [23].

Предпосылки и выраженные компоненты профессиональных деформаций негативно сказываются на индивидуально-психологических особенностях специалистов (психосоматическая симптоматика, редукция личных достижений и профессиональной мотивации, стресс-состояния, эмоциональное истощение) [21], на профессиональной деятельности и ее эффективности (деперсонализация как нарушение системы производственных отношений по вертикали, горизонтали и специалист-клиент, личностное отдаление) [11], на других сферах жизнедеятельности работников (предпосылки асоциального поведения) [18].

Внимание акцентировано на влиянии профессиональных деформаций на профессиональный потенциал вообще и на управленческий потенциал в частности, так как деперсонализация (личностное отдаление), психоэмоциональное (эмоциональное) истощение, редукция личных достижений (профессиональной мотивации) как компоненты профессиональных деформаций являются внутренними факторами нивелирования составляющих управленческого потенциала специалистов (анализ; жизнестойкость; коммуникативные и организаторские способности; лидерские качества; организация работы; планирование деятельности; поддержание производственной эффективности; постановка и достижение целей; профессионализм; профессиональные знания, умения и навыки; раскрытие творческого потенциала; рациональное использование материальных, трудовых, финансовых и энергетических ресурсов; синтез) [19].

Психологи с предпосылками и выраженными компонентами профессиональных деформаций игнорируют проявление индивидуального подхода к клиенту, имеют низкий уровень предвидения и прогнозирования производственных ситуаций, не моделируют проблемные ситуации для дальнейшего их разрешения, отстранены от вопроса проектирования собственного профессионального развития, проигрывают в применении технологий анализа и самоанализа.

Методика и результаты. Из выборки в 4012 психологов была отобрана групna из 392 ncuхологов с ярко выраженными профессиональными деформациями, у которых были диагностированы:

1) по опроснику на выгорание авторов C. Maslach \& S. Jackson [22] в адаптации H.Е. Водопьяновой [7] и модификации интерпретации результатов 0.Б. Поляковой [23] - высокий уровень деперсонализации и профессиональных деформаций вообще, выше среднего уровень редукции личных достижений и эмоционального истощения (табл. 1);

2) по модификации опросника на выгорание авторов C. Maslach \& S. Jackson [22] в адаптации преподавателей Санкт-Петербургского государственного университета [12] и модификации интерпретации результатов 0.Б. Поляковой [23] - высокий уровень деперсонализации и профессиональных деформаций вообще, выше среднего уровень редукции личных достижений и эмоционального истощения (табл. 1);

3) по опроснику на определение психического выгорания автора B.A. Farber [20] в адаптации А.А. Рукавишникова [14] и модификации интерпретации результатов 0.Б. Поляковой [23] - высокий уровень личностного отдаления и профессиональных деформаций вообще, выше среднего уровень психоэмоционального истощения и редукции профессиональной мотивации (табл. 1).

у психологов с профессиональными деформациями были выявлены следующие показатели специфики управленческого потенциала:

1) по опроснику на определение стиля управления руководителя с помощью самооценки Н.П. Фетискина, В.В. Козлова и Г.М. Мануйлова (цель - определить ведущий стиль руководства и степень выраженности каждого из трех классических стилей руководства с помощью самооценки) [10], [14] в модификации результатов 0.Б. Поляковой (табл. 2):

- высокий уровень авторитарного (единоличной власти, злоупотребления наказаниями, лидерства, непредоставления подчиненным самостоятельности, непреклонности и реши- 
Результаты выявления особенностей профессиональных деформаций психологов

\begin{tabular}{|c|c|c|c|c|c|c|c|}
\hline \multicolumn{8}{|c|}{ Опросник на выгорание } \\
\hline \multicolumn{2}{|c|}{$\begin{array}{c}\text { Эмоциональное исто- } \\
\text { щение }\end{array}$} & \multicolumn{2}{|c|}{ Деперсонализация } & \multicolumn{2}{|c|}{$\begin{array}{c}\text { Редукция личных до- } \\
\text { стижений }\end{array}$} & \multicolumn{2}{|c|}{$\begin{array}{c}\text { Профессиональные де- } \\
\text { формации }\end{array}$} \\
\hline 42,31 & $\begin{array}{l}\text { выше средне- } \\
\text { го уровень }\end{array}$ & 27,83 & $\begin{array}{r}\text { высокий } \\
\text { уровень }\end{array}$ & 36,50 & $\begin{array}{l}\text { выше средне- } \\
\text { го уровень }\end{array}$ & 106,64 & $\begin{array}{l}\text { высокий } \\
\text { уровень }\end{array}$ \\
\hline \multicolumn{8}{|c|}{ Модификация опросника на выгорание } \\
\hline \multicolumn{2}{|c|}{$\begin{array}{c}\text { Эмоциональное исто- } \\
\text { щение }\end{array}$} & \multicolumn{2}{|c|}{ Деперсонализация } & \multicolumn{2}{|c|}{$\begin{array}{c}\text { Редукция личных до- } \\
\text { стижений }\end{array}$} & \multicolumn{2}{|c|}{$\begin{array}{c}\text { Профессиональные де- } \\
\text { формации }\end{array}$} \\
\hline 41,98 & $\begin{array}{l}\text { выше средне- } \\
\text { го уровень }\end{array}$ & 28,32 & $\begin{array}{r}\text { высокий } \\
\text { уровень }\end{array}$ & 37,24 & $\begin{array}{l}\text { выше средне- } \\
\text { го уровень }\end{array}$ & 107,54 & $\begin{array}{l}\text { высокий } \\
\text { уровень }\end{array}$ \\
\hline \multicolumn{8}{|c|}{ Определение психического выгорания } \\
\hline \multicolumn{2}{|c|}{$\begin{array}{c}\text { Психоэмоциональное } \\
\text { истощение }\end{array}$} & \multicolumn{2}{|c|}{ Личностное отдаление } & \multicolumn{2}{|c|}{$\begin{array}{c}\text { Редукция профессио- } \\
\text { нальной мотивации }\end{array}$} & \multicolumn{2}{|c|}{$\begin{array}{c}\text { Профессиональные де- } \\
\text { формации }\end{array}$} \\
\hline 48,26 & $\begin{array}{l}\text { выше средне- } \\
\text { го уровень }\end{array}$ & 68,05 & $\begin{array}{l}\text { высокий } \\
\text { уровень }\end{array}$ & 30,34 & $\begin{array}{l}\text { выше средне- } \\
\text { го уровень }\end{array}$ & 146,65 & $\begin{array}{l}\text { высокий } \\
\text { уровень }\end{array}$ \\
\hline
\end{tabular}

тельности в суждениях, низкой совместимости с заместителями, отсутствия учета инициативы подчиненных, предвзятости в оценках, пренебрежения общественным мнением, резкой критики, честолюбия, энергичности и жесткости в требованиях) и либерального (безразличия к интересам коллектива, беспринципности, заигрывания с подчиненными, нежелания брать на себя ответственность и принимать сложные решения, нетребовательности и самоустранения от управления, неумения отстаивать свою точку зрения, низкой степени готовности к постановке целей деятельности, конкретному планированию, панибратства, повышенной внушаемости и слабоволия, попустительства) стилей руководства (табл. 3);

- средний уровень демократического стиля руководства (готовности оказывать доверие заместителям и поощрять их инициативу, желания проявлять заботу о персонале, способности использовать убеждение и принуждение, стремления жить интересами коллектива, умения прислушиваться к мнению персонала) (табл. 3);

2) по опроснику каскадной самооценки хозяйственного руководителя Е.С. Жарикова (цель - выявить предпочтения (склонности) одного из видов управленческой деятельности) [2] в сокращенном варианте Е.П. Ильина [6] в модификации результатов 0.Б. Поляковой (табл. 2):

- высокий уровень управленческой деятельности воспитателя (воспитательной работы среди членов коллектива и клиентов, грамотного инструктирования испытуемых, профессионального чтения лекций и выступления с докладами психологической тематики, психологического просвещения клиентов, четкого разъяснения коллегам смысла и значения психологической документации, эффективного рассмотрения и разрешения конфликтов), кадровика (написания отчетной документации, непосредственного участия в обсуждении и решении управленческих проблем, осуществления служебной переписки, подбора коллег для совместной деятельности, подготовки документации, работы с кадрами), контролера (выявления факторов и осуществления работы по обеспечению выпуска продукции высокого качества, контроля выполнения заданий, осуществления наказаний за нерадивость, совершенствования системы контроля качества работы) и штабного работника (авторитарного принятия решений по проблемам, осуществления команд и распоряжений, планирования, работы с управленческой документацией, разработки инструкций) (табл. 3);

- средний уровень управленческой деятельности общественника (осуществления социального планирования развития трудового коллектива, постановки задач перед клиентами 
и коллегами, работы в президиумах заседаний, участия в качестве ведущего на заседаниях и совещаниях, участия в решении социально-бытовых проблем коллег, частоты произнесения речей на заседаниях, собраниях и совещаниях) и снабженца (желания доставать необходимое для выполнения профессиональных задач, желания находиться в служебных командировках, организации работы служб материально-технического снабжения, осуществления снабженческой деятельности, разработки рациональных способов расходования ресурсов) (табл. 3);

- низкий уровень управленческой деятельности дипломата (вступления в деловые контакты, организации связи с коллегами и другими организациями, представления своего учреждения на совещаниях, установления постоянных связей с психологами других организаций), инноватора (внедрения научных достижений в профессиональную деятельность, поиска научных новинок для внедрения, составления списков нерешенных проблем, убеждения в полезности нововведений), мыслителя (поиска и нивелирования внешних и внутренних факторов, мешающих эффективной профессиональной деятельности, поиска эффективных методов решения профессиональных проблем, разработки списка необходимых изобретений для внедрения) и организатора (организации заседаний и совещаний, организации коллег на выполнение заданий, привлечения коллег к решению управленческих проблем) (табл. 3);

3) при оценке коммуникативно-лидерских способностей личности В.И. Андреева (цель оценить коммуникативно-лидерские способности личности) [1] в модификации результатов 0.Б. Поляковой (табл. 2):

- высокий уровень авторитарного, безразличного, инструктирующего, консервативного, лидерского, монологичного и серьезного управленческих стилей (табл. 3);

- средний уровень агрессивного и эмоционального управленческих стилей (табл. 3);

- низкий уровень ведомого, внушающего, демократического, диалогичного, доброжелательного, рационального, эвристичного, эмпатийного и юмористичного управленческих стилей (табл. 3);

4) по опроснику на эффективность руководства Н.П. Фетискина, В.В. Козлова и Г.М. Мануйлова [17] в модификации результатов 0.Б. Поляковой (табл. 2): средний уровень эффективного руководства (демонстрации доверия к подчиненным, контролирования хода выполнения задания, критических замечаний своим подчиненным, невнимательности, планирования саморазвития на ближайшую перспективу, поощрения инициативы, способности вовлекать подчиненных в процесс обсуждения целей, сроков, методов, ответственности, стремления использовать в работе новейшие достижения в своей профессиональной области, стремления подчеркнуть в людях лучшие качества, уклонения от сотрудничества с другими людьми) (табл. 3).

Таблица 2

Уровневые шкалы процедур диагностики управленческого потенциала психологов

\begin{tabular}{||l|c|c|c|}
\hline \multirow{2}{*}{$\begin{array}{c}\text { Процедуры диагностики } \\
\text { управленческого потенциала } \\
\text { и его составляющих }\end{array}$} & \multicolumn{2}{|c|}{$\begin{array}{c}\text { Уровни выраженности управленческого потенциала } \\
\text { иоставляющих }\end{array}$} \\
\cline { 2 - 4 } & Низкий & Средний & Высокий \\
\hline $\begin{array}{l}\text { Определение стиля управления руко- } \\
\text { водителя с помощью самооценки }\end{array}$ & $0-7$ & $8-13$ & $41-60$ \\
\hline $\begin{array}{l}\text { Опросник каскадной самооценки хо- } \\
\text { зяйственного руководителя }\end{array}$ & $0-20$ & $21-40$ & $8-9$ \\
\hline $\begin{array}{l}\text { Оценка коммуникативно-лидерских } \\
\text { способностей личности }\end{array}$ & $0-4$ & $5-7$ & $28-40$ \\
\hline Эффективность руководства & $0-13$ & $14-27$ & \\
\hline
\end{tabular}


Результаты определения специфики управленческого потенциала психологов с профессиональными деформациями

\begin{tabular}{|c|c|c|c|}
\hline $\begin{array}{c}\text { Процедуры диагностики } \\
\text { управленческого } \\
\text { потенциала }\end{array}$ & $\begin{array}{c}\text { Составляющие } \\
\text { управленческого } \\
\text { потенциала }\end{array}$ & $\begin{array}{c}\text { Средние } \\
\text { арифметические } \\
\text { баллы }\end{array}$ & $\begin{array}{c}\text { Уровень выражен- } \\
\text { ности составляю- } \\
\text { щих управленче- } \\
\text { ского потенциала }\end{array}$ \\
\hline \multirow{3}{*}{$\begin{array}{l}\text { Определение стиля управле- } \\
\text { ния руководителя с помощью } \\
\text { самооценки }\end{array}$} & авторитарный & 18,56 & высокий \\
\hline & демократический & 11,48 & средний \\
\hline & либеральный & 17,53 & высокий \\
\hline \multirow{10}{*}{$\begin{array}{l}\text { Опросник каскадной само- } \\
\text { оценки хозяйственного руко- } \\
\text { водителя }\end{array}$} & мыслитель & 18,03 & низкий \\
\hline & штабной работник & 59,38 & высокий \\
\hline & организатор & 15,37 & низкий \\
\hline & кадровик & 56,92 & высокий \\
\hline & воспитатель & 45,37 & высокий \\
\hline & снабженец & 36,20 & средний \\
\hline & общественник & 28,35 & средний \\
\hline & инноватор & 13,92 & низкий \\
\hline & контролер & 59,25 & высокий \\
\hline & дипломат & 10,38 & низкий \\
\hline \multirow{18}{*}{$\begin{array}{l}\text { Оценка коммуникативно- } \\
\text { лидерских способностей } \\
\text { личности }\end{array}$} & консервативный & 7,92 & высокий \\
\hline & эвристичный & 1,08 & низкий \\
\hline & монологичный & 7,68 & Высокий \\
\hline & диалогичный & 1,32 & низкий \\
\hline & агрессивный & 4,57 & средний \\
\hline & доброжелательный & 4,43 & низкий \\
\hline & ведомый & 1,45 & низкий \\
\hline & лидерский & 7,55 & высокий \\
\hline & эмоциональный & 4,56 & средний \\
\hline & рациональный & 4,44 & низкий \\
\hline & авторитарный & 8,02 & высокий \\
\hline & демократический & 0,98 & низкий \\
\hline & серьезный & 7,56 & Высокий \\
\hline & юмористичный & 1,44 & низкий \\
\hline & инструктирующий & 8,24 & высокий \\
\hline & внушающий & 0,76 & низкий \\
\hline & безразличный & 8,06 & высокий \\
\hline & $\begin{array}{c}\text { эмпатийный (сопережи- } \\
\text { вающий) }\end{array}$ & 0,94 & низкий \\
\hline \multicolumn{2}{|c|}{ Эффективность руководства } & 23,95 & средний \\
\hline
\end{tabular}

0бщие результаты. Выявление тесноты (силы) корреляционной связи между компонентами профессиональных деформаций и составляющими управленческого потенциала психологов (табл. 4) осуществлялось с помощью критерия корреляции К. Пирсона:

1) определена высокая теснота (сила) корреляционной связи между: деперсонализацией / личностным отдалением и авторитарным стилем руководства $(0,79)$, управленческой деятельностью штабного работника $(0,81)$ и контролера $(0,82)$, консервативным $(0,78)$ и инструктирующим $(0,78)$ управленческими стилями; 
2) установлена заметная теснота (сила) корреляционной связи между: эмоциональным / психоэмоциональным истощением и управленческой деятельностью снабженца $(0,69)$ и общественника $(0,56)$, агрессивным управленческим стилем $(0,65)$; редукцией личных достижений / профессиональной мотивации и либеральным $(0,56)$ и демократическим $(0,60)$ стилями руководства, средней эффективностью руководства $(0,65)$.

Таблица 4

Результаты выявления тесноты (силы) корреляционной связи между компонентами профессиональных деформаций и составляющими управленческого потенциала психологов

\begin{tabular}{|c|c|c|c|c|c|c|c|c|c|c|c|c|c|}
\hline \multirow{2}{*}{\multicolumn{2}{|c|}{\begin{tabular}{|c|} 
Аббревиатуры \\
процедур и со- \\
ставляющих \\
\end{tabular}}} & \multicolumn{4}{|c|}{$\mathrm{OHB}$} & \multicolumn{4}{|c|}{ MOHB } & \multicolumn{4}{|c|}{ OПB } \\
\hline & & \multirow{2}{*}{$\begin{array}{c}\text { эи } \\
0,45\end{array}$} & \multirow{2}{*}{$\begin{array}{c}\text { Д } \\
0,75 \\
\end{array}$} & & \multirow{2}{*}{$\begin{array}{c}\text { пд } \\
0,53\end{array}$} & \multirow{2}{*}{$\begin{array}{c}\text { эИ } \\
0,39\end{array}$} & \multirow{2}{*}{$\begin{array}{c}\text { A } \\
0,82\end{array}$} & & \multirow{2}{*}{$\begin{array}{c}\text { пд } \\
0,54\end{array}$} & \multirow{2}{*}{$\begin{array}{l}\text { Пэи } \\
0,42 \\
\end{array}$} & \multirow{2}{*}{\begin{tabular}{|c|} 
л0 \\
0,79 \\
\end{tabular}} & \multirow{2}{*}{$\begin{array}{l}\text { PחM } \\
0,38 \\
\end{array}$} & \multirow{2}{*}{$\begin{array}{l}\text { пम } \\
0,53 \\
\end{array}$} \\
\hline ОСУРСПС & A & & & & & & & & & & & & \\
\hline & Де & 0,28 & 0,16 & 0,63 & 0,36 & 0,30 & 0,19 & 0,60 & 0,36 & 0,31 & 0,21 & 0,58 & 0,37 \\
\hline & $\pi$ & 0,50 & 0,29 & 0,55 & 0,45 & 0,47 & 0,34 & 0,58 & 0,46 & 0,48 & 0,33 & 0,56 & 0,46 \\
\hline \multirow[t]{10}{*}{ OKCXP } & $M$ & 0,34 & 0,28 & 0,19 & 0,27 & 0,31 & 0,25 & 0,22 & 0,26 & 0,30 & 0,29 & 0,26 & 0,28 \\
\hline & ШР & 0,43 & 0,79 & 0,39 & 0,54 & 0,44 & 0,83 & 0,35 & 0,54 & 0,43 & 0,80 & 40 & 0,54 \\
\hline & 0 & 0,37 & 0,24 & 0,20 & 0,27 & 0,34 & 0,20 & 0,18 & 0,24 & 0,31 & 0,27 & 0,17 & 0,25 \\
\hline & K & 0,28 & 0,37 & 0,24 & 0,30 & 0,26 & 0,40 & 0,27 & 0,31 & 29 & 39 & 30 & 0,33 \\
\hline & $B$ & 0,42 & 0,51 & 0,45 & 0,46 & 0,39 & 0,49 & 0,38 & 0,42 & 0,40 & 0,54 & 0,41 & 0,45 \\
\hline & $C$ & 0,67 & 0,46 & 0,49 & 0,54 & & & 0,45 & 52 & 71 & 47 & 44 & \\
\hline & 06 & 0,56 & 0,43 & 0,38 & 0,46 & 0,57 & 0,40 & 0,35 & 0,44 & 0,55 & 0,47 & 0,39 & 0,47 \\
\hline & n & 0,35 & 0,30 & 0,41 & 0,35 & & & 0,40 & & 32 & 32 & 39 & \\
\hline & Кo & 0,37 & 0,87 & 0,28 & 0,51 & 0,39 & 0,79 & 0,30 & 0,49 & 0,35 & 0,81 & 0,27 & 0,48 \\
\hline & Ди & 0,40 & 0,38 & 0,35 & 0,38 & 0,43 & 0,38 & 0,37 & 0,39 & 0,46 & 0,40 & 33 & 0,40 \\
\hline \multirow[t]{18}{*}{ ОКЛСЛ } & Кон & 0,38 & 0,76 & 0,49 & 0,54 & 0,40 & 0,79 & 0,44 & 0,54 & 0,37 & 0,78 & 0,45 & 0,53 \\
\hline & $\ni$ & 0,25 & 0,18 & 0,31 & 0,25 & 0,27 & 0,20 & 0,35 & 0,27 & 28 & 5 & 30 & 8 \\
\hline & Mo & 0,48 & 0,42 & 0,32 & 0,41 & 0,45 & 0,40 & 0,35 & 0,40 & 0,49 & 0,37 & 0,31 & 0,39 \\
\hline & Диа & 0,43 & 0,39 & 0,31 & 0,38 & 0,45 & 0,34 & 0,36 & 0,38 & 0,44 & 0,38 & 0,39 & 0,40 \\
\hline & $\mathrm{Ar}$ & 0,63 & 0,42 & 0,47 & 0,51 & 0,67 & 0,40 & 0,38 & 0,48 & 0,64 & 0,38 & 0,36 & 0,46 \\
\hline & До & 0,35 & 0,27 & 0,41 & 0,34 & 0,38 & 0,30 & 0,39 & 0,36 & 0,32 & 0,26 & 0,42 & 0,33 \\
\hline & $\mathrm{Be}$ & 0,43 & 0,3 & 0,34 & 0,39 & 0,40 & 0,3 & 0,37 & & 0,45 & 0,32 & 0,33 & \\
\hline & Ли & 0,32 & 0,41 & 0,25 & 0,33 & 0,29 & 0,43 & 0,24 & 0,32 & 0,30 & 0,47 & 0,21 & 0,33 \\
\hline & Эм & 0,47 & 0,4 & 0,32 & 0,40 & 0,49 & 0,44 & 0,30 & 0,41 & 0,45 & 0,49 & 0,34 & 0 \\
\hline & $\mathrm{P}$ & 0,25 & 0,39 & 0,24 & 0,29 & 0,20 & 0,40 & 0,26 & 0,29 & 0,27 & 0,37 & 0,29 & 0,31 \\
\hline & A & 0,41 & 0,5 & 0,25 & 0,39 & 0,3 & 0,48 & 0,24 & 0,37 & 0,43 & 0,52 & 0,22 & 0,39 \\
\hline & Де & 0,28 & 0,42 & 0,53 & 0,41 & 0,30 & 0,40 & 0,51 & 0,40 & 0,31 & 0,43 & 0,54 & 0,43 \\
\hline & $\mathrm{Ce}$ & 0,46 & 0,48 & 0,33 & 0,42 & 0,50 & 0,45 & 0,36 & 0,44 & 0,46 & 0,50 & 0,32 & 0,43 \\
\hline & 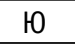 & 0,39 & 0,43 & 0,30 & 0,37 & 0,41 & 0,45 & 0,29 & 0,38 & 0,44 & 0,38 & 0,31 & 0,38 \\
\hline & $n$ & 0,47 & 0,75 & 0,30 & 0,51 & 0,50 & 0,78 & 0,27 & 0,52 & 0,46 & 0,81 & 0,31 & 0,53 \\
\hline & $\mathrm{BH}$ & 0,26 & 0,31 & 0,28 & 0,28 & 0,29 & 0,34 & 0,25 & 0,29 & 0,25 & 0,36 & 0,27 & 0,29 \\
\hline & E & 0,48 & 0,45 & 0,32 & 0,42 & 0,50 & 0,47 & 0,34 & 0,44 & 0,47 & 0,46 & 0,39 & 0,44 \\
\hline & Эмп & 0,25 & 0,31 & 0,21 & 0,26 & 0,29 & 0,34 & 0,19 & 0,27 & 0,27 & 0,30 & 0,16 & 0,24 \\
\hline & 0,41 & 0,37 & 0,70 & 0,49 & 0,38 & 0,40 & 0,64 & 0,47 & 0,40 & 0,35 & 0,62 & 0,46 \\
\hline
\end{tabular}

Примечание: опросник на выгорание (ОНВ), модификация опросника на выгорание (МОНВ), эмоциональное истощение (ЭИ), деперсонализация (Д), редукция личных достижений (РЛД), профессиональные деформации (ПД); определение психического выгорания (ОПВ), психоэмоциональное истощение (ПЭИ), личностное отдаление (Л0), редукция профессиональной мотивации (РПМ); опре- 
деление стиля управления руководителя с помощью самооценки (ОСУРСПС), авторитарный (А), демократический (Де), либеральный (Л); опросник каскадной самооценки хозяйственного руководителя (ОКСХР), мыслитель (М), штабной работник (ШР), организатор (0), кадровик (К), воспитатель (В), снабженец (С), общественник (0б), инноватор (И), контролер (Ко), дипломат (Ди); оценка коммуникативно-лидерских способностей личности (ОКЛСЛ), консервативный (Кон), эвристичный (Э), монологичный (Мо), диалогичный (Диа), агрессивный (Аг), доброжелательный (До), ведомый (Ве), лидерский (Ли), эмоциональный (Эм), рациональный (Р), авторитарный (А), демократический (Де), серьезный (Се), юмористичный (Ю), инструктирующий (И), внушающий (Вн), безразличный (Б), эмпатийный (Эмп); эффективность руководства (ЭР); точна оченка силы корреляционной связи согласно таблице Чеддока: менее 0,3 - слабая, 0,3-0,5 - умеренная, 0,5-0,7 - заметная, 0,7-0,9 - высокая, более 0,9 - весьма заметная. Примечание: опросник на выгорание (0НВ), модификация опросника на выгорание (МОНВ), эмоциональное истощение (ЭИ), деперсонализация (Д), редукция личных достижений (РЛД), профессиональные деформации (ПД); определение психического выгорания (0ПВ), психоэмоциональное истощение (ПЭИ), личностное отдаление (Л0), редукция профессиональной мотивации (РПМ); определение стиля управления руководителя с помощью самооценки (ОСУРСПС), авторитарный (А), демократический (Де), либеральный (Л); опросник каскадной самооценки хозяйственного руководителя (ОКСХР), мыслитель (М), штабной работник (ШР), организатор (0), кадровик (К), воспитатель (В), снабженец (С), общественник (0б), инноватор (И), контролер (Ко), дипломат (Ди); оценка коммуникативно-лидерских способностей личности (ОКЛСЛ), консервативный (Кон), эвристичный (Э), монологичный (Мо), диалогичный (Диа), агрессивный (Аг), доброжелательный (До), ведомый (Ве), лидерский (Ли), эмоциональный (Эм), рациональный (Р), авторитарный (А), демократический (Де), серьезный (Се), юмористичный (Ю), инструктирующий (И), внушающий (Вн), безразличный (Б), эмпатийный (Эмп); эффективность руководства (ЭР); точна оценка силы корреляционной связи согласно таблице Чеддока: менее 0,3 - слабая, 0,3-0,5- умеренная, 0,5-0,7 - заметная, 0,7-0,9 - высокая, более 0,9 - весьма заметная.

Обсуждение. Профессиональные деформации специалистов как психологический феномен, внешние и внутренние факторы, негативно сказывающиеся на эффективности профессиональной деятельности и индивидуально-психологических особенностях личности работников, рассматриваются в контексте:

1) изучения профессионального правового сознания [8];

2) исследования особенностей профессиональной адаптации [15];

3) описания индивидуального ресурса профессионального развития [4];

4) определения компонентов профессиональных деформаций [16];

5) прогнозирования возникновения и профилактики предпосылок профессиональных деформаций [9];

6) противодействия внешним и внутренним факторам возникновения профессиональных деформаций [13];

7) раскрытия механизмов профессионального дизонтогенеза и зависимости профессиональных деформаций от стадий профессионального развития [3];

8) рассмотрения индикаторов отклонений психического здоровья [5].

Заключение. Спещифика управленческого потенциала психологов с профессиональными деформациями (высоким личностным отдалением, высокой деперсонализацией, выше среднего степенью редукции личных достижений и профессиональной мотивации, повышенным психоэмоциональным и эмоциональным истощением) заключается: в высоком уровне авторитарного и либерального стилей руководства, безразличного, инструктирующего, консервативного, лидерского, монологичного и серьезного управленческих стилей, управленческой деятельности воспитателя, кадровика, контролера и штабного работника; в средней степени агрессивного и эмоционального управленческих стилей, демократического стиля руководства; управленческой деятельности общественника и снабженца, эффективного руководства; в слабо выраженной управленческой деятельности дипломата, инноватора, мыслителя и организатора, при низкой выраженности ведомого, внушающего, 
демократического, диалогичного, доброжелательного, рационального, эвристичного, эмпатийного и юмористичного управленческих стилей.

Благодарность всем психологам, согласившимся участвовать в исследовании.

\section{Список литературы}

1. Андреев В.И. Педагогика творческого саморазвития. Казань: Казан. ун-т, 1996. 567 с.

2. Барабашева Н.С., Жариков Е.С. Как выбирается руководитель? М.: Знание, 1989. 64 с.

3. Гончарова Н.А. Психологические закономерности зависимости профессиональных деформаций личности от стадий профессионального развития // Вестник Тверского государственного университета. Серия: Педагогика и психология. 2018. № 3. С. 11-18.

4. Дробышевская Е.В., Башлакова Л.В. Концепция профессиональной деформации как индивидуального ресурса профессионального развития // Электронный научно-просветительский журнал. София, 2018. № 1. С. 8-16.

5. Дружилов С.А. Профессиональные деформации и деструкции как индикаторы отклонений психического здоровья специалиста // Фундаментальные исследования. 2011. № 5. C. 56-61.

6. Ильин Е.П. Мотивация и мотивы. СПб.: Питер, 2000. 512 с.

7. Ильин Е.П. Эмоции и чувства. СПб.: Питер, 2001. 752 с.

8. Крыжевская Н.Н. Профессиональное правовое сознание как стержневое личностное образование, препятствуюее формированию профессиональной деформации // Актуальные проблемы гуманитарных и естественных наук. 2016. № 1-4. С. 131-134.

9. Лунин А.Д., Лунина М.А., Щупак А.Ю. Прогнозирование и профилактика возможной профессиональной деформации личности, находившейся в экстремальных условиях профессиональной деятельности // Личность в экстремальных условиях и кризисных ситуациях жизнедеятельности. 2014. № 4. С. 49-53.

10. Определение стиля управления руководителя с помощью самооценки. URL: http:// brunner.kgu.edu.ua/index.php/psy-metodiks/20-2010-07-08-04-48-24/479-samoupravrukovodit (дата обращения: 11.01.2020).

11. Полякова 0.Б. Самоконтроль в общении как фактор преодоления состояний деперсонализации психологов и педагогов // Вестник Томского государственного университета. 2011. № 348. С. 133-137.

12. Практикум по психологии профессиональной деятельности. СПб.: СПбГУ, 2000. 304 с.

13. Сыманюк Э.Э., Печеркина А.А. Противодействие профессиональным деформациям // Народное образование. 2010. № 9 (1402). С. 265-269.

14. Фетискин Н.П., Козлов В.В., Мануйлов Г.М. Социально-психологическая диагностика развития личности и малых групп. М.: Ин-т психотерапии, 2002. 490 c.

15. Шатов А.А. Профессиональная деформация и профессиональная адаптация личности // Форум. Серия: гуманитарные и экономические науки. 2018. № 3 (15). С. 165-167.

16. Шевченко А.А. Профессиональная деформация смысложизненных ориентаций личности в структуре профессиональных деструкций // Международный научно-исследовательский журнал. 2012. № 5-3 (5). С. 94-95.

17. Энциклопедия психологических тестов. М.: Эксмо-Пресс, 2000. $496 \mathrm{c.}$

18. Bonkalo T.I., Polyakova O.B., Bonkalo S.V., Kolesnik N.T., Sorokoumova E.A. Development of ethnic social identity among the members of ethnic community organizations as the factor of preventing the spread of nationalist sentiments in a multicultural society // Biosciences Biotechnology Research Asia. Vol. 12. 2015. No. 3. P. 2361-2372.

19. Elshansky S.P., Anufriev A.F., Polyakova O.B., Semenov D.V. Positive personal qualities and depression // Prensa Medica Argentina. Vol. 104. 2018. No. 6. P. 1000322.

20. Farber B.A. Introduction: A critical perspective on burnout // Stress and burnout in the human service professions. N.Y.: Pergamon Press, 1983. P. 1-20.

21. Jafar Zade D.A., Senkevich L.V., Polyakova O.B., Basimov M.M., Strelkov V.I., Tarasov M.V. Features of professional deformations (burnout) of medical workers depending on working conditions // Prensa Medica Argentina. Vol. 105. 2019. No. 1. P. 1000334.

22. Maslach C., Jackson S. MBI: Maslach Burnout Inventory: research edition. Palo Alto, CA: Consulting Psychologists Press, 1981. P. 13-15.

23. Polyakova 0.B., Petrova E.A., Mironova 0.I., Semenov D.V. Specificity of psychosomatization of psychologist-leaders with professional deformations (burnout) // Prensa Medica Argentina. Vol. 105. 2019. No. 1. P. 1000326. 


\section{References}

1. Andreev V.I. Pedagogika tvorcheskogo samorazvitiya. Kazan': Kazan. un-t, 1996. 567 s.

2. Barabasheva N.S., Zharikov E.S. Kak vybiraetsya rukovoditel'? M.: Znanie, 1989. 64 s.

3. Goncharova N.A. Psikhologicheskie zakonomernosti zavisimosti professional'nykh deformacij lichnosti ot stadij professional'nogo razvitiya // Vestnik Tverskogo gosudarstvennogo universiteta. Seriya: Pedagogika i psikhologiya. 2018. № 3. S. 11-18.

4. Drobyshevskaya E.V., Bashlakova L.V. Koncepciya professional'noj deformacii kak individual'nogo resursa professional'nogo razvitiya // Elektronnyj nauchno-prosvetitel'skij zhurnal. Sofiya, 2018. № 1. S. 8-16.

5. Druzhilov S.A. Professional'nye deformacii i destrukcii kak indikatory otklonenij psikhicheskogo zdorov'ya specialista // Fundamental'nye issledovaniya. 2011. № 5. S. 56-61.

6. Il'in E.P. Motivaciya i motivy. SPb.: Piter, 2000. $512 \mathrm{~s}$.

7. Il'in E.P. Emocii i chuvstva. SPb.: Piter, 2001. $752 \mathrm{s.}$

8. Kryzhevskaya N.N. Professional'noe pravovoe soznanie kak sterzhnevoe lichnostnoe obrazovanie, prepyatstvuyushchee formirovaniyu professional'noj deformacii // Aktual'nye problemy gumanitarnykh i estestvennykh nauk. 2016. № 1-4. S. 131-134.

9. Lunin A.D., Lunina M.A., Shchupak A.Yu. Prognozirovanie i profilaktika vozmozhnoj professional'noj deformacii lichnosti, nakhodivshejsya $v$ ekstremal'nykh usloviyakh professional'noj deyatel'nosti // Lichnost' v ekstremal'nykh usloviyakh i krizisnykh situaciyakh zhiznedeyatel'nosti. 2014. № 4. S. 49-53.

10. Opredelenie stilya upravleniya rukovoditelya $s$ pomoshch'yu samoocenki. URL: http:// brunner.kgu.edu.ua/index.php/psy-metodiks/20-2010-07-08-04-48-24/479-samoupravrukovodit (data obrashcheniya: 11.01 .2020 ).

11. Polyakova 0.B. Samokontrol' $\vee$ obshchenii kak faktor preodoleniya sostoyanij depersonalizacii psikhologov i pedagogov // Vestnik Tomskogo gosudarstvennogo universiteta. 2011. № 348. S. $133-137$.

12. Praktikum po psikhologii professional'noj deyatel'nosti. SPb.: SPbGU, 2000. $304 \mathrm{~s}$.

13. Symanyuk E.E., Pecherkina A.A. Protivodejstvie professional'nym deformaciyam // Narodnoe obrazovanie. 2010. № 9 (1402). S. 265-269.

14. Fetiskin N.P., Kozlov V.V., Manujlov G.M. Social'no-psikhologicheskaya diagnostika razvitiya lichnosti i malykh grupp. M.: In-t psikhoterapii, 2002. $490 \mathrm{~s}$.

15. Shatov A.A. Professional'naya deformaciya i professional'naya adaptaciya lichnosti // Forum. Seriya: gumanitarnye i ekonomicheskie nauki. 2018. № 3 (15). S. 165-167.

16. Shevchenko A.A. Professional'naya deformaciya smyslozhiznennykh orientacij lichnosti $\checkmark$ strukture professional'nykh destrukcij // Mezhdunarodnyj nauchno-issledovatel'skij zhurnal. 2012. № 5-3 (5). S. 94-95.

17. Enciklopediya psikhologicheskikh testov. M.: Eksmo-Press, 2000. $496 \mathrm{~s}$.

18. Bonkalo T.I., Polyakova O.B., Bonkalo S.V., Kolesnik N.T., Sorokoumova E.A. Development of ethnic social identity among the members of ethnic community organizations as the factor of preventing the spread of nationalist sentiments in a multicultural society // Biosciences Biotechnology Research Asia. Vol. 12. 2015. No. 3. P. 2361-2372.

19. Elshansky S.P., Anufriev A.F., Polyakova O.B., Semenov D.V. Positive personal qualities and depression // Prensa Medica Argentina. Vol. 104. 2018. No. 6. P. 1000322.

20. Farber B.A. Introduction: A critical perspective on burnout // Stress and burnout in the human service professions. N.Y.: Pergamon Press, 1983. P. 1-20.

21. Jafar Zade D.A., Senkevich L.V., Polyakova O.B., Basimov M.M., Strelkov V.I., Tarasov M.V. Features of professional deformations (burnout) of medical workers depending on working conditions // Prensa Medica Argentina. Vol. 105. 2019. No. 1. P. 1000334.

22. Maslach C., Jackson S. MBI: Maslach Burnout Inventory: research edition. Palo Alto, CA: Consulting Psychologists Press, 1981. P. 13-15.

23. Polyakova 0.B., Petrova E.A., Mironova 0.I., Semenov D.V. Specificity of psychosomatization of psychologist-leaders with professional deformations (burnout) // Prensa Medica Argentina. Vol. 105. 2019. No. 1. P. 1000326.

\section{Библиографическое описание статьи / Reference to article}

Полякова О.Б. Специфика управленческого потенциала психологов с профессиональными деформациями // Ученые записки Российского государственного социального университета. Т. 19. 2020. № 1 (154). С. 45-54. D0I: 10.17922/2071-5323-2020-19-1-45-54 (Библиографическое описание согласно российским стандартам). 
Polyakova 0.B. Specifika upravlencheskogo potenciala psikhologov s professional'nymi deformaciyami // Uchenye zapiski Rossijskogo gosudarstvennogo social'nogo universiteta. T. 19. 2020. № 1 (154). S. 45-54. D0I: 10.17922/2071-5323-2020-19-1-45-54 (Reference in Roman script).

Polyakova, 0.B. (2020) The Specifics of the Managerial Potential of Psychologists with Professional Deformations, Scientific Notes of Russian State Social University. Vol. 19. No. 1 (154). P. 45-54. DOI: 10.17922/2071-5323-2020-19-1-45-54 (International bibliographic description). 


\title{
В.Ф. Соколова,
}

канд. филос. наук, заведующая кафедрой гуманитарных

и естественнонаучных дисциплин, Западный филиал

Российской академии народного хозяйства и государственной службы

при Президенте Российской Федерации, Калининград.

V.F. Sokolova,

candidate of philosophical sciences, head of the department of humanities and natural sciences, Western branch of the Russian Presidential Academy of National Economy and Public Administration, Kaliningrad.

E-mail: vera_sokolova@inbox.ru

\section{Н.А. Цветкова,}

д-р психол. наук, профессор кафедры социальной, общей и клинической психологии, Российский государственный социальный университет;

ведущий научный сотрудник Научно-исследовательского института ФСИН России, Москва.

N.A. Tsvetkova,

doctor of psychological sciences, professor of the department of social, general and clinical psychology, Russian State Social University; leading researcher of the Scientific Research Institute of the Federal Service for the Execution of Punishments of Russia, Moscow.

E-mail:TsvetkovaNA@yandex.ru

\section{Сравнительный анализ социально-психологических характеристик работающих людей среднего И пожИлого возрастов}

\author{
Comparative Analysis of Socio-Psychological Characteristics \\ of Middle-Aged and Elderly Working People
}

\author{
Дата поступления \\ Дата препринта \\ Дата публикации \\ 18.12.2019 \\ 28.02.2020 \\ 30.03.2020
}

Аннотация: в статье представлены результаты эмпирического исследования, проведенного на выборке 100 человек в целях выявления различий в социально-психологических характеристиках работающих людей среднего (45-59 лет) и пожилого (60-65 лет) возрастов. Сравнивались показатели самооценки, доверия, эмоциональных модальностей, стиля саморегуляции поведения, деструктивных коммуникативных установок, стиля поведения в конфликте. Установлено, что работающие люди среднего возраста в отличие от работающих пожилых людей характеризуются достоверно более высокими показателями: общего уровня эмоциональности, в том числе переживания радости; гибкости в поведении; открытой жестокости; негативного личного опыта общения, сотрудничества и соперничества. В то же время они характеризуются более низкими показателями доверия $\kappa$ людям, завуалированной жестокости, компромисса. Значимые различия по семи показателям обнаружены между мужчинами среднего и пожилого возрастов; по восьми - между двумя возрастными группами женщин. В заключении статьи поднят вопрос о необходимости подготовки специалистов кадровых служб к работе с персоналом, перешагнувшим 60-летний рубеж.

Annotation: the article presents the results of an empirical study conducted on a sample of 100 people in order to identify differences in the socio-psychological characteristics of working people of middle (45- 
59 years) and older (60-65 years) ages. Indicators of self-esteem, trust, emotional modalities, self-regulation style of behavior, destructive communicative attitudes, and behavior style in conflict were compared. It was found that working middle-aged people, in contrast to working older people, are characterized by significantly higher indicators: the general level of emotion, including feelings of joy; flexibility in behavior; open cruelty; negative personal experience of communication, cooperation and competition. At the same time, they are characterized by lower indicators of trust in people, veiled cruelty, and compromise. Significant differences for the seven indicators are discovered among the men of middle and elderly ages; the eight - between the two age groups of women. In conclusion, the article raises the question of the need to train specialists of human resources services to work with personnel who have crossed the 60-year mark.

Ключевые слова: средний возраст, пожилой возраст, работающие мужчины и женщины, социально-психологические характеристики, сравнительный анализ.

Key words: middle age, old age, working men, working women, socio-psychological characteristics, comparative analysis.

Введение. Возрастная классификация, принятая на Международном съезде в 1965 году, в 2016 году была пересмотрена Всемирной организацией здравоохранения. Люди стали жить дольше, поэтому В03 официально установила следующие границы возрастов: 18-44 молодой возраст; 45-59 - средний возраст; 60-74- пожилой возраст; 75-90- старческий возраст; 90 и более лет - возраст долгожительства. Эта социально-демографическая реальность отразилась на российском пенсионном законодательстве: начавшаяся с 1 января 2019 года пенсионная реформа предполагает постепенное увеличение возраста граждан, по достижении которого они смогут получать пенсию по старости. В итоге в России на пять лет увеличится пенсионный возраст у мужчин (65 лет) и женщин (60 лет). Вместе с этим возникает вопрос о социально-психологических характеристиках россиян, вынужденных продолжать профессионально-трудовую деятельность, отметив свои 60-летие и 65-летие. Например, важно понять, как может измениться социально-психологический климат в трудовых коллективах в связи с тем, что в них с каждым годом будет больше сотрудников, чей возраст превысил 60-летний рубеж. Эти знания нужны практическим социальным психологам, работникам кадровых служб, социальным работникам [15; 18], политологам [13] и др.

К настоящему времени в данном направлении уже появились научные разработки в отечественной $[2 ; 3 ; 5 ; 11 ; 14 ; 15$ и др.] и зарубежной психологии [19; 20], создана теоретикометодологическая база для продолжения исследований $[4 ; 7 ; 8 ; 9 ; 12 ; 14 ; 16$ и др.]. 0днако если людей среднего возраста в научной литературе рассматривают как достигших вершины жизни (акмэ), то пожилых - как предсказуемо слабнущих, отдаляющихся от дел и «доживающих». К типичным «слабостям» социально-психологического компонента личности вторых относят: заниженные уровни самооценки и самоуважения, возрастание неопределенности, изменение структуры психологического времени, склонность к беспричинной грусти, снижение способности справляться с трудностями, социальной активности, коммуникабельности и др. Типизировано социальное поведение пожилых людей [11], особым образом создающих напряжение и на работе, и в домашнем кругу: 1) люди с ненасытной потребностью в самоутверждении; 2) однообразные в социальном взаимодействии (не могут выйти из некогда выбранных ими ролей); 3) сосредоточенные на своих ощущениях (человек мнителен, полон мрачных предчувствий, слишком озабочен своим здоровьем); 4) с нестандартным социальным поведением (они требуют, чтобы окружающие люди подстраивались под них, хотя их убеждения устарели, а действия не соответствуют групповым нормам и ценностям); 5) недооценивающие себя как личность, со страхом быть неинтересными другим. Такого человека обычно не замечают, а он это болезненно переживает.

Эмпирическое исследование, по результатам которого написана данная статья, проводилось в 2019 году. Его целью стало выявление различий в личностных характеристиках работающих мужчин и женщин среднего и пожилого возрастов. Выборку исследования составили 50 мужчин и 50 женщин в возрасте от 45 до 65 лет. Группа людей среднего возраста (45-59 лет) имела среднее значение возраста 50 лет; группа пожилых (60-65 лет) - 62 года. 
По роду занятий: рабочие - 28 человек (28\%); госслужащие - 20 человек $(20 \%)$; работники системы здравоохранения - 18 человек (18\%); педагоги - 12 человек (12\%); инженеры 5 человек (5\%); бухгалтеры - 4 человека (4\%); представители среднего бизнеса - 9 человек $(9 \%)$; научные сотрудники - 1 человек (1\%), юристы - 1 человек $(1 \%)$; работники системы сервиса и обслуживания - 2 человека (2\%).

Методы и методики исследования применялись следующие: 1) исследование самооценки с помощью процедуры ранжирования 20-и качеств личности; 2) четырехмодальный эмоциональный опросник Л.А. Рабинович, модифицированный Е.П. Ильиным [6]; 3) шкала доверия М. Розенберга [17]; 4) тест «Стиль саморегуляции поведения» В.И. Моросановой [10]; 5) тест «Деструктивные коммуникативные установки» В.В. Бойко [17]; 6) методика «Стиль поведения в конфликте», разработанная К. Томасом, в адаптации Н.В. Гришиной [17].

Математико-статистическая обработка данных выполнена на основе программ MS Office Excel, IBM SPSS Statistics 23. Сравнительный анализ данных выполнялся по t-критерию Стьюдента.

Результаты исследования и обсуждение.

1. Данные, полученные по шести методикам, систематизированы по критерию «Социально-психологические характеристики работающих людей двух возрастных смешанных групп» и приведены в таблице 1.

Таблица 1

Социально-психологические характеристики работающих людей двух возрастных смешанных групп - среднего и пожилого возрастов

\begin{tabular}{|c|c|c|}
\hline \multirow{2}{*}{$\begin{array}{c}\text { Социально-психологическая } \\
\text { характеристика }\end{array}$} & \multicolumn{2}{|c|}{ Сравниваемые группы (по средним значениям) } \\
\hline & $\begin{array}{c}\text { Группа мужчин и женщин } \\
\text { среднего возраста }\end{array}$ & $\begin{array}{l}\text { Группа мужчин и женщин } \\
\text { пожилого возраста }\end{array}$ \\
\hline 1. Самооценка & 0,64 & 0,67 \\
\hline \multicolumn{3}{|l|}{ 2. Эмоциональные модальности } \\
\hline Радость & 25,7 & 22,2 \\
\hline Гнев & 17,0 & 15,8 \\
\hline Страх & 16,8 & 16,3 \\
\hline Печаль & 9,3 & 9,5 \\
\hline Общий уровень эмоциональности & 68,8 & 63,8 \\
\hline 3. Доверие к людям & 0,8 & 1,1 \\
\hline \multicolumn{3}{|c|}{ 4. Особенности стиля саморегуляции поведения (ССП) } \\
\hline Общий уровень ССП & 33,5 & 32,8 \\
\hline Гибкость & 6,1 & 5,5 \\
\hline Самостоятельность & 5,0 & 5,0 \\
\hline Моделирование & 5,8 & 6,0 \\
\hline Программирование & 5,4 & 5,1 \\
\hline Оценка результатов & 5,8 & 5,5 \\
\hline Планирование & 5,4 & 5,6 \\
\hline \multicolumn{3}{|c|}{ 5. Деструктивные установки в межличностном общении } \\
\hline Обоснованный негативизм & 58,5 & 56,2 \\
\hline Завуалированная жестокость & 60,8 & 66,9 \\
\hline Открытая жестокость & 52,7 & 46,9 \\
\hline Негативный личный опыт общения & 46,4 & 40,6 \\
\hline Брюзжание & 40,4 & 42,6 \\
\hline \multicolumn{3}{|c|}{ 6. Стратегии поведения в конфликте } \\
\hline Соперничество & 2,9 & 2,3 \\
\hline Сотрудничество & 6,4 & 5,8 \\
\hline Компромисс & 7,3 & 7,8 \\
\hline Избегание & 7,0 & 7,3 \\
\hline Приспособление & 6,2 & 6,5 \\
\hline
\end{tabular}


Таблица 1 показывает, что: 1) уровень самооценки в обеих группах средний; 2) ведущей эмоциональной модальностью в обеих группах является радость; 3) уровень доверия к людям в обеих группах низкий; 4) стиль саморегуляции поведения является гармоничным, однако показатели его структурных компонентов находятся на среднем уровне развитости; 5) среди деструктивных коммуникативных установок в обеих группах доминирует завуалированная жестокость. Обеим группам присущи «розовые очки», то есть обследованные далеко не всегда способны заметить то, что у других вызывает обоснованный негативизм; 6) в конфликтных ситуациях в обеих группах предпочтение отдается компромиссу и избеганию.

Результаты анализа этих данных на достоверность различий представлены в таблице 2.

Таблица 2

Достоверные различия

\begin{tabular}{|l|c|c|}
\hline \multicolumn{1}{|c|}{ Сравниваемые параметры } & $\begin{array}{c}\text { Критерий } \\
\text { Стьюдента (t) }\end{array}$ & $\begin{array}{c}\text { Уровень } \\
\text { достоверности (p) }\end{array}$ \\
\hline 1. Радость & 3,754 & 0,000 \\
\hline 2. Общий уровень эмоциональности & 2,468 & 0,014 \\
\hline 3. Доверие к людям & $-2,024$ & 0,044 \\
\hline 4. Гибкость & 3,225 & 0,001 \\
\hline 5. Завуалированная жестокость & $-2,685$ & 0,008 \\
\hline 6. Открытая жестокость & 1,950 & 0,052 \\
\hline 7. Негативный личный опыт общения & 1,931 & 0,054 \\
\hline 8. Соперничество & 1,932 & 0,054 \\
\hline 9. Сотрудничество & 3,123 & 0,002 \\
\hline 10. Компромисс & $-2,495$ & 0,013 \\
\hline
\end{tabular}

Примечание: серым цветом отмечены менее значимые различия.

Таблицы 1 и 2 показывают, что между смешанными группами людей среднего и пожилого возрастов существуют достоверные различия: а) по показателю эмоциональной модальности «радость», а также по общему уровню эмоциональности (они выше в группе людей среднего возраста); б) по уровню доверия (оно выше в группе пожилых); в) по гибкости (ее показатель выше в группе людей среднего возраста); г) по показателям деструктивных коммуникативных установок (в группе пожилых людей завуалированная жестокость выше, чем у людей среднего возраста, а открытая - ниже; ниже и показатель негативного личного опыта общения); д) по стратегии поведения в конфликте: люди среднего возраста более склонны к соперничеству и сотрудничеству, а пожилые - к компромиссу.

2. Данные, объединенные по критерию «Социально-психологические характеристики двух возрастных групп мужчин», отображены в таблице 3.

Результаты анализа этих данных на достоверность различий представлены в таблице 4.

Таблицы 3 и 4 показывают, что между мужчинами среднего и пожилого возрастов существуют достоверные различия: а) по общему уровню эмоциональности, а в частности по радости (эти показатели выше в группе мужчин среднего возраста); б) гибкости ее показатель в структуре стиля саморегуляции поведения выше у мужчин среднего возраста; в) завуалированной жестокости - она более выражена в группе пожилых мужчин; г) стратегии поведения в конфликте (показатель соперничества выше у мужчин среднего возраста, а приспособления - у пожилых; у пожилых также выше склонность к компромиссу). 
Социально-психологические характеристики двух возрастных групп мужчин среднего и пожилого возрастов

\begin{tabular}{|c|c|c|}
\hline \multirow[t]{2}{*}{ Социально-психологическая характеристика } & \multicolumn{2}{|c|}{$\begin{array}{c}\text { Сравниваемые группы } \\
\text { (по средним значениям) }\end{array}$} \\
\hline & $\begin{array}{c}\text { Мужчины } \\
\text { среднего возраста }\end{array}$ & $\begin{array}{c}\text { Мужчины } \\
\text { пожилого возраста }\end{array}$ \\
\hline 1. Самооценка & 0,67 & 0,68 \\
\hline \multicolumn{3}{|l|}{ 2. Эмоциональные модальности } \\
\hline Радость & 25,8 & 17,8 \\
\hline Гнев & 17,9 & 15,6 \\
\hline Страх & 11,2 & 13,0 \\
\hline Печаль & 9,2 & 9,6 \\
\hline Общий уровень эмоциональности & 64,1 & 56,0 \\
\hline 3. Доверие к людям & 0,72 & 0,79 \\
\hline \multicolumn{3}{|l|}{ 4. Особенности стиля саморегуляции поведения (ССП) } \\
\hline Общий уровень ССП & 33,0 & 31,5 \\
\hline Гибкость & 6,2 & 5,3 \\
\hline Самостоятельность & 5,4 & 4,9 \\
\hline Моделирование & 5,8 & 5,9 \\
\hline Программирование & 4,6 & 4,9 \\
\hline Оценка результатов & 5,7 & 5,2 \\
\hline Моделирование & 5,8 & 5,9 \\
\hline Планирование & 5,4 & 5,3 \\
\hline \multicolumn{3}{|c|}{ 5. Деструктивные установки в межличностном общении } \\
\hline Обоснованный негативизм & 63,2 & 60,0 \\
\hline Завуалированная жестокость & 61,8 & 74,6 \\
\hline Открытая жестокость & 57,4 & 54,9 \\
\hline Негативный личный опыт общения & 53,0 & 46,1 \\
\hline Брюзжание & 44,0 & 41,4 \\
\hline \multicolumn{3}{|l|}{ 6. Стратегии поведения в конфликте } \\
\hline Соперничество & 4,0 & 2,5 \\
\hline Сотрудничество & 6,1 & 6,0 \\
\hline Компромисс & 7,0 & 7,6 \\
\hline Избегание & 7,1 & 7,3 \\
\hline Приспособление & 5,4 & 6,2 \\
\hline
\end{tabular}

Таблица 4

Достоверные различия

\begin{tabular}{|l|c|c|}
\hline \multicolumn{1}{|c|}{ Сравниваемые параметры } & $\begin{array}{c}\text { Критерий } \\
\text { Стьюдента (t) }\end{array}$ & $\begin{array}{c}\text { Уровень } \\
\text { достоверности (p) }\end{array}$ \\
\hline 1. Радость & 6,650 & 0,000 \\
\hline 2. Общий уровень эмоциональности & 3,288 & 0,001 \\
\hline 3. Гибкость & 3,562 & 0,000 \\
\hline 4. Завуалированная жестокость & $-4,068$ & 0,000 \\
\hline 5. Соперничество & 3,620 & 0,000 \\
\hline 6. Компромисс & $-2,034$ & 0,043 \\
\hline 7. Приспособление & $-2,964$ & 0,003 \\
\hline
\end{tabular}


3. Данные, объединенные по критерию «Социально-психологические характеристики двух возрастных женских групп», содержатся в таблице 5.

Таблица 5

Социально-психологические характеристики двух возрастных групп женщин - среднего и пожилого возрастов

\begin{tabular}{|c|c|c|}
\hline \multirow{2}{*}{$\begin{array}{c}\text { Социально-психологическая } \\
\text { характеристика }\end{array}$} & \multicolumn{2}{|c|}{ Сравниваемые группы (по средним значениям) } \\
\hline & $\begin{array}{c}\text { Женщины } \\
\text { среднего возраста }\end{array}$ & $\begin{array}{c}\text { Женщины } \\
\text { пожилого возраста }\end{array}$ \\
\hline 1. Самооценка & 0,62 & 0,65 \\
\hline \multicolumn{3}{|l|}{ 2. Эмоциональные модальности } \\
\hline Радость & 25,5 & 28,7 \\
\hline Гнев & 16,3 & 16,2 \\
\hline Страх & 21,8 & 21,3 \\
\hline Печаль & 9,4 & 9,2 \\
\hline Общий уровень эмоциональности & 73,0 & 75,4 \\
\hline 3. Доверие к людям & 0,96 & 1,47 \\
\hline \multicolumn{3}{|c|}{ 4. Особенности стиля саморегуляции поведения (ССП) } \\
\hline Общий уровень ССП & 34,0 & 34,6 \\
\hline Гибкость & 6,0 & 5,7 \\
\hline Самостоятельность & 4,8 & 5,2 \\
\hline Планирование & 5,5 & 6,1 \\
\hline Моделирование & 5,8 & 6,2 \\
\hline Программирование & 6,0 & 5,5 \\
\hline Оценка результатов & 5,9 & 5,9 \\
\hline \multicolumn{3}{|c|}{ 5. Деструктивные установки в межличностном общении } \\
\hline Обоснованный негативизм & 54,3 & 50,5 \\
\hline Брюзжание & 37,1 & 44,2 \\
\hline Негативный личный опыт общения & 40,5 & 32,6 \\
\hline Завуалированная жестокость & 59,8 & 55,6 \\
\hline Открытая жестокость & 48,4 & 35,3 \\
\hline \multicolumn{3}{|l|}{ 6. Стратегии поведения в конфликте } \\
\hline Соперничество & 1,9 & 2,1 \\
\hline Сотрудничество & 6,6 & 5,5 \\
\hline Компромисс & 7,6 & 8,2 \\
\hline Избегание & 7,0 & 7,3 \\
\hline Приспособление & 6,9 & 6,8 \\
\hline
\end{tabular}

Результаты анализа этих данных на достоверность различий представлены в таблице 6.

Таблица 6

Достоверные различия

\begin{tabular}{|l|c|c|}
\hline \multicolumn{1}{|c|}{ Сравниваемые параметры } & Критерий Стьюдента (t) & Уровень достоверности (p) \\
\hline 1. Радость & $-2,694$ & 0,008 \\
\hline 2. Доверие к людям & $-3,025$ & 0,003 \\
\hline 3. Планирование & $-2,086$ & 0,038 \\
\hline 4. Программирование & 2,166 & 0,032 \\
\hline 5. Открытая жестокость & 3,034 & 0,003 \\
\hline 6. Негативный личный опыт общения & 2,034 & 0,043 \\
\hline 7. Сотрудничество & 3,598 & 0,000 \\
\hline 8. Компромисс & $-2,102$ & 0,037 \\
\hline
\end{tabular}


Таблицы 5 и 6 показывают межгрупповые различия в показателях по параметрам: а) эмоциональная модальность «Радость» (показатель выше в группе пожилых женщин); б) доверие (он так же выше в группе пожилых женщин; в) стиль саморегуляции поведения (показатель жизненно важного умения «Планирование» выше у пожилых женщин, а программирования - у женщин среднего возраста); г) деструктивные коммуникативные установки (показатели: «0ткрытая жестокость» и «Негативный личный опыт общения» выше в группе женщин среднего возраста); д) стратегия поведения в конфликте (в группе женщин среднего возраста достоверно выше показатель сотрудничества, а в группе пожилых женщин - компромисса).

4. Обобщенные по критерию «Социально-психологические характеристики мужчин и женщин среднего и пожилого возрастов» данные представлены в таблице 7.

Таблица 7

Общая сводная таблица результатов исследования (средние значения)

\begin{tabular}{|c|c|c|c|c|}
\hline \multirow{2}{*}{$\begin{array}{c}\text { Социально-психологическая } \\
\text { характеристика }\end{array}$} & \multicolumn{4}{|c|}{ Сравниваемые группы } \\
\hline & $\begin{array}{l}\text { Мужчины } \\
\text { среднего } \\
\text { возраста }\end{array}$ & $\begin{array}{c}\text { Женщины } \\
\text { среднего } \\
\text { возраста }\end{array}$ & $\begin{array}{c}\text { Мужчины } \\
\text { пожилого } \\
\text { возраста }\end{array}$ & $\begin{array}{c}\text { Женщины } \\
\text { пожилого } \\
\text { возраста }\end{array}$ \\
\hline 1. Самооценка & 0,67 & 0,62 & 0,68 & 0,65 \\
\hline \multicolumn{5}{|l|}{ 2. Эмоциональные модальности } \\
\hline Радость & 25,8 & 25,5 & 17,8 & 28,7 \\
\hline Гнев & 17,9 & 16,3 & 15,6 & 16,2 \\
\hline Страх & 11,2 & 21,8 & 13,0 & 21,3 \\
\hline Печаль & 9,2 & 9,4 & 9,6 & 9,2 \\
\hline Общий уровень эмоциональности & 64,1 & 73,0 & 56,0 & 75,4 \\
\hline 3. Доверие к людям & 0,72 & 0,96 & 0,79 & 1,47 \\
\hline \multicolumn{5}{|c|}{ 4. Особенности стиля саморегуляции поведения (ССП) } \\
\hline Общий уровень ССП & 33,0 & 34,0 & 31,5 & 34,6 \\
\hline Гибкость & 6,2 & 6,0 & 5,3 & 5,7 \\
\hline Самостоятельность & 5,4 & 4,8 & 4,9 & 5,2 \\
\hline Планирование & 5,4 & 5,5 & 5,3 & 6,1 \\
\hline Моделирование & 5,8 & 5,8 & 5,9 & 6,2 \\
\hline Программирование & 4,6 & 6,0 & 4,9 & 5,5 \\
\hline Оценка результатов & 5,7 & 5,9 & 5,2 & 5,9 \\
\hline \multicolumn{5}{|c|}{ 5. Деструктивные установки в межличностном общении } \\
\hline 0боснованный негативизм & 63,2 & 54,3 & 60,0 & 50,5 \\
\hline Брюзжание & 44,0 & 37,1 & 41,4 & 44,2 \\
\hline Негативный личный опыт общения & 53,0 & 40,5 & 46,1 & 32,6 \\
\hline Завуалированная жестокость & 61,8 & 59,8 & 74,6 & 55,6 \\
\hline Открытая жестокость & 57,4 & 48,4 & 54,9 & 35,3 \\
\hline \multicolumn{5}{|l|}{ 6. Стратегии поведения в конфликте } \\
\hline Соперничество & 4,0 & 1,9 & 2,5 & 2,1 \\
\hline Сотрудничество & 6,1 & 6,6 & 6,0 & 5,5 \\
\hline Компромисс & 7,0 & 7,6 & 7,6 & 8,2 \\
\hline Избегание & 7,1 & 7,0 & 7,3 & 7,3 \\
\hline Приспособление & 5,4 & 6,9 & 6,2 & 6,8 \\
\hline
\end{tabular}

Таблица 7 показывает, что: 1) самооценка мужчин и женщин обеих возрастных групп является адекватной; 2) самый высокий показатель общего уровня эмоциональности име- 
ют пожилые женщины, а самый низкий - пожилые мужчины; женщины обеих групп имеют гораздо более высокий показатель страха, чем мужчины обеих групп; показатель радости заметно выше у пожилых женщин; 3) показатели доверия в обеих смешанных группах находятся на низком уровне; 4) относительно низкий общий уровень саморегуляции поведения наблюдается в группе пожилых мужчин; 5) доминирующей деструктивной коммуникативной установкой всей выборки является завуалированная жестокость, причем в большей степени она выражена у пожилых мужчин и в меньшей - у пожилых женщин; «розовые очки» более свойственны пожилым женщинам, а менее - мужчинам среднего возраста; у мужчин среднего возраста относительно более высокие показатели негативного личного опыта общения и открытой жестокости; самый низкий показатель негативного личного опыта общения наблюдается у пожилых женщин; 6) более предпочтительными стратегиями поведения в конфликте для всей выборки являются компромисс и избегание, при этом компромисс более характерен для женщин пожилого возраста. В большей степени склонны к соперничеству мужчины среднего возраста.

Выводы. Результаты сравнительного анализа социально-психологических характеристик работающих людей среднего и пожилого возрастов позволяют вынести на обсуждение следующие выводы.

1. Обследованные люди среднего и пожилого возрастов имеют достоверные различия по ряду замеренных параметров - это «общий уровень эмоциональности» и, в частности, «радость»; «гибкость» как структурный компонент стиля саморегуляции поведения; «завуалированная жестокость» как деструктивная коммуникативная установка; «сотрудничество» и «компромисс» как наиболее предпочитаемые стили выхода из конфликта. Различия обнаруживаются также по параметрам: «доверие», «открытая жестокость», «негативный личный опыт общения», «соперничество».

2. Работающие люди среднего возраста в отличие от работающих людей пожилого возраста характеризуются более высокими показателями: переживания радости и общим уровнем эмоциональности; гибкости в поведении; открытой жестокости, негативного личного опыта общения, сотрудничества и соперничества, - а также более низкими показателями: доверия к людям, завуалированной жестокости, компромисса. Очевидно, что на седьмом десятке жизни у работающих людей: ослабляется способность переживать радость и снижается общий уровень эмоциональности; появляется больше жесткости в поведении; становится меньше проявлений открытой жестокости, но больше - завуалированной; прошлый личный опыт негативного общения переосмысляется и оптимизируется; в конфликтных ситуациях предпочтение реже отдается сотрудничеству или соперничеству, но чаще - стратегии компромисса; возрастает доверие к людям.

3. Работающие люди среднего и пожилого возрастов - это мужчины и женщины, различающиеся по целому ряду социально-психологических характеристик. Установлено, что у мужчин среднего возраста в отличие от женщин этого же возраста ниже уровень страха, общий уровень эмоциональности, доверия к людям, развитости программирования как жизненно важного умения, склонности прибегать к сотрудничеству, компромиссу и приспособлению в конфликтных ситуациях и они реже одевают «розовые очки». В то же время у них выше уровень деструктивных установок в межличностном общении - негативного личного опыта общения, завуалированной и открытой жестокости, брюзжания; в ситуациях конфликта они чаще предпочитают стратегию соперничества. У мужчин пожилого возраста в отличие от пожилых женщин ниже уровни радости и страха, а также общий уровень эмоциональности; ниже уровень доверия, уровни развитости жизненно важных умений - планирования, программирования, оценки результатов, а также общий уровень саморегуляции; они реже брюзжат и пользуются «розовыми очками», реже приспосабливаются или соглашаются на компромисс. В отличие от пожилых женщин у пожилых мужчин выше показатели деструктивных установок - завуалированной и открытой жестокости, негативного личного опыта общения. 
Значимые различия обнаружены также между мужчинами среднего и пожилого возрастов (по 7-и замеряемым параметрам), между женщинами среднего и пожилого возрастов (по 8-и).

Полученные результаты указывают на необходимость подготовки специалистов кадровых служб к работе с персоналом, перешагнувшим 60-летний рубеж. Работодателям целесообразно иметь кадровиков, которые могли бы выявлять половозрастные изменения социально-психологических характеристик работников и принимать меры профилактики разновидных социальных конфликтов. В этом плане эффективны индивидуальное и групповое психологическое консультирование, а также активное социально-психологическое обучение персонала с применением различных методов - тренинга, дискуссии, ролевой игры, кейсов, квестов и других.

\section{Список литературы}

1. Болотова А.К. Психология развития и возрастная психология: учебник для вузов. СПб.: Питер, 2018. 478 c.

2. Горизонты зрелости: сб. науч. ст. / под ред. Л.Ф. Обуховой и др. М.: ГБоу Впо Мгппу, 2015. $246 \mathrm{c}$.

3. Долгова В.И., Тимофеева И.В. Исследование Я-концепции женщин в период проживания кризиса среднего возраста // Концепт. 2016. Т. 7. С. 96-100. URL: http://e-koncept. ru/2016/56097.htm (дата обращения: 14.09.2019).

4. Донцов Д.А., Сенкевич Л.А., Рыбакова А.И. Психология личности: учеб. пособие. М.: Русайнс, 2017. 302 c.

5. Жучкова С.М. Социально-психологические детерминанты удовлетворенности жизнью в пожилом и старческом возрасте: дис. ... канд. психол. наук. М., 2018. 220 с.

6. Ильин Е.П. Эмоции и чувства. СПб.: Питер, 2001. С. 524-527.

7. Колодяжная 0.Ю. Основные подходы к исследованию психического развития человека среднего возраста в психологической науке // Актуальные направления научных исследований: от теории к практике: матер. VI Междунар. науч.-практ. конф. (Чебоксары, 27 сент. 2015 г.). Чебоксары: ЦНС «Интерактив плюс», 2015. С. 129-132.

8. Корчемный П.А., Климова Е.М. Сравнительный анализ подходов к основным проблемам психологической науки в XXI веке // Человеческий капитал. 2016. № 4 (88). С. 8-10.

9. Кулагина И.Ю., Колюцкий В.Н. Возрастная психология: Полный жизненный цикл развития человека: учеб. пособие. М.: ТЦ «Сфера», 2001. 464 с.

10. Моросанова В.И. Психология саморегуляции: учеб. пособие. СПб.: Нестор-История, 2012. $280 \mathrm{c.}$

11. Мусина-Мазнова Г.Х., Сорокина И.А., Потапова И.А. Типологические особенности социальной адаптированности и дезадаптированности людей пожилого возраста // Общество: социология, психология, педагогика. 2017. № 7. URL: https://cyberleninka.ru/article/n / tipologicheskie-osobennosti-sotsialnoy-adaptirovannosti-i-dezadaptirovannosti-lyudeypozhilogo-vozrasta (дата обращения: 14.09.2019).

12. Нестерова А.А., Жучкова С.М. Факторная структура удовлетворенности жизнью в пожилом и старческом возрасте: социально-психологический подход // Вестник МгоУ. Серия: Психологические науки. 2018. № 1. С. 60-72.

13. Петрова Е.А. Национальная стратегия действий в интересах женщин на 2017-2022 годы и вопросы имиджа деловой женщины в современной России // Имидж деловой женщины в эпоху цифровых трансформаций: матер. IV Междунар. женского конгресса (СанктПетербург, 29 июня - 1 июля 2017 г.). М.: АИМ, 2017. С. 14-21.

14. Психологическая поддержка лиц зрелого и пожилого возрастов: коллективная монография / под ред. Н.А. Цветковой. М.: Русайнс, 2019. 172 с.

15. Рыбакова Н.А. Социальная работа и социальное образование: условия сохранения и развития жизненных сил человека в динамике социобытия: монография. Псков: ПГПИ им. С.М. Кирова, 2000. 184 с.

16. Смык Ю.В. Психология взрослого человека и основы геронтопсихологии. Иркутск: Изд-во BCГАО, 2013. $94 \mathrm{C}$.

17. Фетискин Н.П., Козлов В.В., Мануйлов Г.М. Социально-психологическая диагностика личности и малых групп. М.: ИП, 2002. 368 с. 
18. Цветкова Н.А., Рыбакова А.И. Психология социальной работы и психосоциальная работа с населением как прикладные области деятельности ученых кафедры социальной психологии РГСУ // Социальная психология в РГСУ: итоги и перспективы: монография / под ред. Е.А. Петровой. М.: РИЦ АИМ, 2011. Гл. 5. С. 62-91.

19. Anthis K., La Voie Joseph C. Readiness to change: A longitudinal study of changes in adult identity // Journal of Research in Personality. Vol. 40. 2006. Issue 2. April. P. 209-219.

20. Caspi A., Roberts B.W. Personality development across the life course: the argument for change and continuity // Psychological Inquiry. 2001. No. 12. P. 49-66.

\section{References}

1. Bolotova A.K. Psikhologiya razvitiya i vozrastnaya psikhologiya: uchebnik dlya vuzov. SPb.: Piter, 2018. $478 \mathrm{~s}$.

2. Gorizonty zrelosti: sb. nauch. st. / pod red. L.F. Obukhovoj i dr. M.: GBOU VPO MGPPU, 2015. $246 \mathrm{~s}$.

3. Dolgova V.I., Timofeeva I.V. Issledovanie Ya-koncepcii zhenshchin v period prozhivaniya krizisa srednego vozrasta // Koncept. 2016. T. 7. S. 96-100. URL: http://e-koncept. ru/2016/56097.htm (data obrashcheniya: 14.09.2019).

4. Doncov D.A., Senkevich L.A., Rybakova A.I. Psikhologiya lichnosti: ucheb. posobie. M.: Rusajns, 2017. $302 \mathrm{~s}$.

5. Zhuchkova S.M. Social'no-psikhologicheskie determinanty udovletvorennosti zhizn'yu v pozhilom i starcheskom vozraste: dis. ... kand. psikhol. nauk. M., 2018. 220 s.

6. Il'in E.P. Emocii i chuvstva. SPb.: Piter, 2001. S. 524-527.

7. Kolodyazhnaya 0.Yu. Osnovnye podkhody k issledovaniyu psikhicheskogo razvitiya cheloveka srednego vozrasta $v$ psikhologicheskoj nauke // Aktual'nye napravleniya nauchnykh issledovanij: ot teorii k praktike: mater. VI Mezhdunar. nauch.-prakt. konf. (Cheboksary, 27 sent. 2015 g.). Cheboksary: CNS «Interaktiv plyus», 2015. S. 129-132.

8. Korchemnyj P.A., Klimova E.M. Sravnitel'nyj analiz podkhodov k osnovnym problemam psikhologicheskoj nauki v XXI veke // Chelovecheskij kapital. 2016. № 4 (88). S. 8-10.

9. Kulagina I.Yu., Kolyuckij V.N. Vozrastnaya psikhologiya: Polnyj zhiznennyj cikl razvitiya cheloveka: ucheb. posobie. M.: TC «Sfera», 2001. 464 S.

10. Morosanova V.I. Psikhologiya samoregulyacii: ucheb. posobie. SPb.: Nestor-Istoriya, 2012. $280 \mathrm{~s}$.

11. Musina-Maznova G.Kh., Sorokina I.A., Potapova I.A. Tipologicheskie osobennosti social'noj adaptirovannosti i dezadaptirovannosti lyudej pozhilogo vozrasta // Obshchestvo: sociologiya, psikhologiya, pedagogika. 2017. № 7. URL: https://cyberleninka.ru/article/n/ tipologicheskie-osobennosti-sotsialnoy-adaptirovannosti-i-dezadaptirovannosti-lyudeypozhilogo-vozrasta (data obrashcheniya: 14.09.2019).

12. Nesterova A.A., Zhuchkova S.M. Faktornaya struktura udovletvorennosti zhizn'yu v pozhilom i starcheskom vozraste: social'no-psikhologicheskij podkhod // Vestnik MGOU. Seriya: Psikhologicheskie nauki. 2018. № 1. S. 60-72.

13. Petrova E.A. Nacional'naya strategiya dejstvij v interesakh zhenshchin na 2017-2022 gody i voprosy imidzha delovoj zhenshchiny v sovremennoj Rossii // Imidzh delovoj zhenshchiny $\checkmark$ epokhu cifrovykh transformacij: mater. IV Mezhdunar. zhenskogo kongressa (SanktPeterburg, 29 iyunya - 1 iyulya 2017 g.). M.: AIM, 2017. S. 14-21.

14. Psikhologicheskaya podderzhka lic zrelogo i pozhilogo vozrastov: kollektivnaja monografiya / pod red. N.A. Cvetkovoj. M.: Rusajns, 2019. 172 s.

15. Rybakova N.A. Social'naya rabota i social'noe obrazovanie: usloviya sokhraneniya i razvitiya zhiznennykh sil cheloveka v dinamike sociobytiya: monografiya. Pskov: PGPI im. S.M. Kirova, 2000. $184 \mathrm{~s}$.

16. Smyk Yu.V. Psikhologiya vzroslogo cheloveka i osnovy gerontopsikhologii. Irkutsk: Izd-vo VSGA0, 2013. $94 \mathrm{~s}$.

17. Fetiskin N.P., Kozlov V.V., Manujlov G.M. Social'no-psikhologicheskaya diagnostika lichnosti i malykh grupp. M.: IP, 2002. $368 \mathrm{~s}$.

18. Cvetkova N.A., Rybakova A.I. Psikhologiya social'noj raboty i psikhosocial'naya rabota s naseleniem kak prikladnye oblasti deyatel'nosti uchenykh kafedry social'noj psikhologii RGSU // Social'naya psikhologiya v RGSU: itogi i perspektivy: monografiya / pod red. E.A. Petrovoj. M.: RIC AIM, 2011. Gl. 5. S. 62-91.

19. Anthis K., La Voie Joseph C. Readiness to change: A longitudinal study of changes in adult identity // Journal of Research in Personality. Vol. 40. 2006. Issue 2. April. P. 209-219. 
20. Caspi A., Roberts B.W. Personality development across the life course: the argument for change and continuity // Psychological Inquiry. 2001. No. 12. P. 49-66.

\section{Библиографическое описание статьи / Reference to article}

Соколова В.Ф., Цветкова Н.А. Сравнительный анализ социально-психологических характеристик работающих людей среднего и пожилого возрастов // Ученые записки Российского государственного социального университета. Т. 19. 2020. № 1 (154). C. 55-65. DOI: 10.17922/2071-5323-2020-19-1-55-65 (Библиографическое описание согласно российским стандартам).

Sokolova V.F., Cvetkova N.A. Sravnitel'nyj analiz social'no-psikhologicheskikh kharakteristik rabotayushchikh lyudej srednego i pozhilogo vozrastov // Uchenye zapiski Rossijskogo gosudarstvennogo social'nogo universiteta. T. 19. 2020. № 1 (154). S. 55-65. D0I: 10.17922/2071-5323-2020-19-1-55-65 (Reference in Roman script).

Sokolova, V.F. \& Tsvetkova, N.A. (2020) Comparative Analysis of Socio-Psychological Characteristics of Middle-Aged and Elderly Working People, Scientific Notes of Russian State Social University. Vol. 19. No. 1 (154). P. 55-65. D0I: 10.17922/2071-5323-2020-19-1-55-65 (International bibliographic description). 


\title{
Е.А. Петрова,
}

д-р психол. наук, профессор, декан факультета психологии,

заведующая кафедрой социальной, общей и клинической психологии,

Российский государственный социальный университет, Москва.

E.A. Petrova,

doctor of psychological sciences, professor, dean of the faculty of psychology,

head of the department of social, general and clinical psychology,

Russian State Social University, Moscow.

E-mail:petrova-sorina@yandex.ru

\section{А.Б. Горячева,}

магистрантка, Российский государственный социальный университет, Москва.

A.B. Goryacheva,

master student, Russian State Social University, Moscow.

E-mail: alla19712008@bk.ru

\section{Сравнительный анализ субъективного благополучия студентов с разной академической успеваемостью в зависимости от ступени обучения}

\author{
Comparative Analysis of the Subjective Well-Being of Students with \\ Different Academic Achievements in the Dependence of the Level of Study
}

Дата поступления

24.12.2019
Дата препринта

28.02.2020

\author{
Дата публикации
}

30.03.2020

Аннотация: в статье описаны ход и результаты исследования взаимосвязи субъективного благополучия и академической успеваемости в зависимости от ступени обучения. Исследование проводилось в целях установления взаимосвязей и факторов, влияющих на повышение академической успеваемости учащихся. Обследовалось 68 студентов бакалавриата и магистратуры РГСу с помощью триады методик: «Шкала субъективного счастья» С. Любомирски, Ш.С. Леппер, «Шкала Надежды» С. Снайдер и «Шкала удовлетворенности жизнью» Э. Динер. Понятие академической успеваемости рассматривалось как процентное соотношение оценок к другим баллам, полученным в ходе экзаменационной сессии. В результате проведенного исследования были сделаны выводы, что уровень субъективного благополучия у студентов-магистров по всем критериям выше, чем уровень субъективного благополучия у студентов-бакалавров. Взаимосвязь уровня субъективного благополучия и академической успеваемости студентов обеих ступеней (бакалавриат, магистратура) зависит только от уровня надежды и не зависит от уровня субъективного счастья и удовлетворенности жизнью.

Annotation: the article describes the progress and results of research on the relationship between subjective well-being and academic performance depending on the level of education. The purpose of the study was to establish the interrelationships and factors that influence the improvement of academic performance of students. 68 undergraduate and graduate students of the Russian State Social University were surveyed using a triad of methods: "The subjective happiness scale" C. Lubomirsky, S.S. Lepper, "Hope scale" S. Snyder, "The satisfaction with life scale" E. Diener. The notion of academic achievement was considered as a percentage of grades to other points obtained during the exam session. As a result of the research, it was concluded that the level of subjective well-being of masters' students by all criteria is higher than that of bachelor students. The relationship between the level of subjective well-being and academic performance 
of students at both levels (undergraduate, graduate) depends only on the level of hope and does not depend on the level of subjective happiness and satisfaction with life.

Ключевые слова: субъективное благополучие, Шкала надежды, Субшкала пути, Субшкала действия, удовлетворенность жизнью.

Key words: Subjective well-being, Scale of hope, Pathway subscale, Subscale of action, Satisfaction with life.

Введение. В середине XX столетия проблемы восприятия счастья, оптимизма, надежды, удовлетворенности жизнью и другие вопросы активно обсуждались в сфере научной психологии. После нескольких десятков лет забвения интерес к данной области научного знания благодаря исследованиям И.А. Джидарьян [5], Л.В. Куликова [6, с. 138], Е.Д. Бабановой [2, с. 18], 0.С. Сычева [16], Д.А. Леонтьева [17], В.А. Петровского [11], К. Муздыбаева [9], Д. Майерса [8, с. 87-96] и других вновь активизировался. Тем не менее узкие направления в этом научном вопросе, такие как взаимосвязь категорий счастья и академической успеваемости студентов, остаются малоизученными, а актуальность проблемы низкой успеваемости данной группы весьма высока.

К сожалению, согласно Росстату, ежегодно из российских вузов отчисляются $12 \%$ учащихся [4].

Характерно, что 8\% от общего числа отчисленных - это студенты 1 и 2 курсов, что говорит нам о трудностях адаптации учащихся к учебно-профессиональной деятельности на начальном этапе обучения.

Результаты исследования взаимосвязи таких категорий, как субъективное благополучие и академическая успеваемость в зависимости от степени адаптированности студентов к учебному процессу, могут найти достойное применение в российском образовании.

Теоретический анализ конструкта «субъективное благополучие» и важности психологического благополучия в успешности учебной деятельности человека, в нашем случае - учебной деятельности студента, мы проводим на основе научных разработок Э. Динера, которые получили в 1984 году название «Концепция субъективного благополучия». Согласно его теории данный конструкт целесообразно выразить следующей формулой: субъективное благополучие = когнитивная составляющая + эмоциональный компонент [19].

Основоположник концепции субъективного благополучия полагает, что «общий уровень удовлетворенности в каждый конкретный момент времени свидетельствует о степени расхождения между жизненной реальностью и личными стандартами "хорошей жизни"» [20]. Данная теория получила широкое распространение, и в нашем исследовании мы опирались именно на эти утверждения.

Обращаясь в своей работе к теме исследования субъективного благополучия студентов вуза, необходимо отметить, что, переступив порог вуза, студенты испытывают стресс, обусловленный адаптацией к новым, предложенным им условиям.

Реакция студентов на внешние стрессоры - это волнение. Данный период у студентов-новичков характеризуется фазой тревоги и способствует активизации защитных сил, но вместе с тем привносит негативное действие на эмоциональное состояние юношей и девушек [15].

М. Перре полагает, что стрессовые события делятся на две группы: макрострессоры (кардинально изменяющие жизнь) и микрострессоры (долговременные, фрустрирующие факторы), и именно микрострессоры, к которым относятся академическая неуспеваемость, еда низкого качества, плохие условия проживания, разочарование в профессии, накапливаясь в течение длительного времени, существенно снижают уровень удовлетворенности жизнью индивида [10].

Л.В. Тарасенко согласна с данным утверждением и подчеркивает, что микрострессоры имеют свойство накапливаться и с течением времени оказывают более разрушительное действие на психологическое благополучие человека, чем макрострессоры. Л.В. Тарасенко проводила масштабное исследование на выборке студентов МППГУ. Так, анализируя настроение студентов, автор отмечает, что на первом курсе основной проблемой студентов явля- 
ется перегрузка знаниями (23\%), а к середине второго курса - отсутствие цели и смысла к освоению будущей профессии (13,1\%) [17, с. 24]. Как мы видим, у студентов начального этапа обучения имеются свои специфические проблемы, которые не могут не учитываться в оценке удовлетворенности жизнью, которая является когнитивной составляющей субъективного благополучия и снижает эмоциональный фон учащихся.

У студентов магистратуры, для которых учебная деятельность не является новой, также имеются специфические трудности. А. Роботова отмечала, что психоэмоциональный дискомфорт может испытывать разновозрастной состав аудитории, общение студентов между собой требует гибкости, деликатности, обучение - большого объема самостоятельного изучения материала, увеличения учебной нагрузки и ужесточения требований к качеству выполненных заданий [14, с. 66-77]. Высокая планка поставленных задач значимо влияет на уровень психологического благополучия студентов.

По мнению М. Аргайла [1], Т.Ю. Фадеевой [18], И. Бонивел [3, с. 21-22], субъективное счастье, удовлетворенность жизнью, надежда являются необходимыми компонентами для достижения поставленной цели, в нашем случае - целей, направленных на достижение успешности обучения.

Так как ведущей деятельностью студента является учебно-профессиональная деятельность, то в данной работе для нас важно было рассматривать субъективное благополучие студентов в тесном контексте с их академической успеваемостью как один из критериев эффективности обучения, в котором оценка выступает как продукт профессионально-учебной деятельности студента. В свою очередь, обучение, как каждая совместная деятельность, сопровождается субъективной оценкой своих успехов и возможностей и имеет уникальную для данного субъекта эмоциональную окраску.

Недостаточная изученность теоретических и практических подходов в научном исследовании влияния уровня субъективного благополучия студентов на уровень их академической успеваемости привела нас к необходимости выдвижения и дальнейшей проверки следующих научных гипотез.

Общая гипотеза: взаимосвязь уровня субъективного благополучия и академической успеваемости студентов зависит от курса и ступени их обучения (бакалавриат, магистратура).

\section{Частные гипотезы:}

1) гендерный фактор не существенен для понимания уровня субъективного благополучия студентов;

2) студенты, обучающиеся по программам бакалавриата и магистратуры, имеют значимые отличия в уровне субъективного благополучия;

3) уровень субъективного благополучия учащихся 1 и 2 курсов бакалавриата отличается в зависимости от курса их обучения.

В целях изучения данного научного вопроса мы провели эмпирическое исследование. Данное исследование проводилось в период с января по июль 2019 года на базе федерального государственного бюджетного образовательного учреждения высшего образования «Российский государственный социальный университет».

В ходе исследования были задействованы 68 испытуемых в возрасте от 19 до 30 лет, являющихся бакалаврами и магистрами очной формы обучения по направлению «Психология». В ходе эксперимента испытуемые были разделены на контрольную и экспериментальную группы, по 34 человека каждая.

Кроме этого все испытуемые были разделены в зависимости от формы обучения и пола. Таким образом, мы получили следующие подгруппы, представленные в таблице 1: магистры 32 человека - учащиеся 1 курса, бакалавры - 36 человек; 1 курс - 17 человек, 2 курс - 19 человек. Женщины - 50 человек, мужчины - 18 человек.

Методики. Данное исследование строилось на следующих научных основополагающих теориях в изучении психологии счастья: «Теория Палиса и Литла» - данная теория опреде- 
ляет стратегию жизни индивида, которая подчиняет себе определенные личностные задачи; «Теория гедонистической адаптации» П.Д. Брикмана и Д.Т. Кемпбела; «Теория социального сравнения» Карпа и Михалоса; «Теория расширения и постройки» Барбары Фредриксон; «Теория потока» М. Чиксентмихайи. Ключевое значение в данной работе имеет Концепция субъективного благополучия.

Для проведения эксперимента нами были использованы следующие методики:

- «Шкала субъективного счастья» для измерения эмоционального компонента, отражающего общий уровень психологической удовлетворенности (авторы: Lybomirsky S., Lepper H.S. Адаптация: Елшанский С.П., Ануфриев А.Ф., Камалетдинова 3.Ф., Сапарин 0.Е., Семёнов Д.В.) $[12$, c. 1];

- «Шкала надежды» для исследования значимости планирования и достижения цели и оценки чувства успешности в деятельности (автор: Snyder S. Адаптация: Елшанский С.П., Ануфриев А.Ф., Камалетдинова 3.Ф., Сапарин 0.Е., Семёнов Д.В.) [6, с. 3];

- «Шкала удовлетворенности жизнью» для исследования уровня когнитивной составляющей субъективного благополучия, как отличной от других аффективных составляющих (автор: Diner Е. Адаптация: Елшанский С.П., Ануфриев А.Ф., Камалетдинова 3.Ф., Сапарин 0.Е., Семёнов Д.В.) [13, с. 5].

Результаты. Первостепенной задачей в нашем исследовании была задача проведения анализа уровня субъективного благополучия и академической успеваемости учащихся вуза в зависимости от ступени образования (бакалавры/магистры). Для этого мы сравнили средние показатели по всем методикам в обеих группах. Результаты представлены в таблице 1.

Таблица 1

Средние значения для сравнения бакалавров и магистров по методикам уровня благополучия, субъективного счастья и надежды

\begin{tabular}{|c|c|c|c|c|c|c|}
\hline $\begin{array}{c}\text { Средний } \\
\text { показа- } \\
\text { тель }\end{array}$ & $\begin{array}{c}\text { Шкала субъ- } \\
\text { ективного } \\
\text { счастья }\end{array}$ & $\begin{array}{c}\text { Субшкала } \\
\text { действия }\end{array}$ & $\begin{array}{c}\text { Субшка- } \\
\text { ла пути }\end{array}$ & $\begin{array}{c}\text { Общая } \\
\text { шкала }\end{array}$ & $\begin{array}{c}\text { Шкала удов- } \\
\text { летворенно- } \\
\text { сти жизнью }\end{array}$ & $\begin{array}{c}\text { \% оценок «отлично» } \\
\text { в экзаменационных } \\
\text { показателях }\end{array}$ \\
\hline Бакалавры & 19 & 22 & 23 & 46 & 21 & 76,00 \\
\hline Магистры & 24 & 25 & 31 & 52 & 26 & 85,00 \\
\hline
\end{tabular}

Наглядно соотношение показателей по всем исследуемым параметрам в обеих группах представлены на рисунке 1.

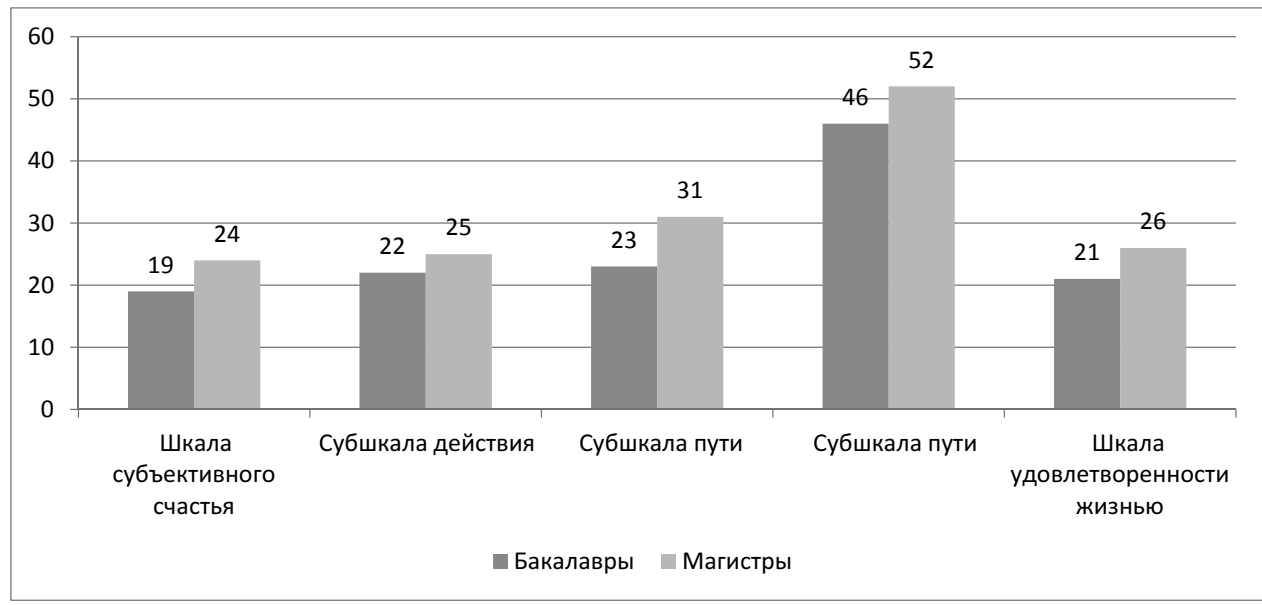

Puс. 1. Сравнение средних показателей по шкалам опросников 
При исследовании различий по U-критерию Манна-Уитни были получены результаты, которые представлены в таблице 2.

Таблица 2

Значения U-критерия для сравнения бакалавров и магистров по методикам уровня благополучия, субъективного счастья и надежды

\begin{tabular}{|c|c|c|c|c|c|c|}
\hline \multirow{2}{*}{$\begin{array}{c}\text { Средний } \\
\text { показатель }\end{array}$} & \multirow{2}{*}{$\begin{array}{l}\text { Шкала субъ- } \\
\text { ективного } \\
\text { счастья }\end{array}$} & \multicolumn{3}{|c|}{ Шкала надежды } & \multirow{2}{*}{$\begin{array}{l}\text { Шкала удов- } \\
\text { летворенно- } \\
\text { сти жизнью }\end{array}$} & \multirow{2}{*}{$\begin{array}{l}\text { \% оценок «отлич- } \\
\text { но» в экзаменаци- } \\
\text { онных показателях }\end{array}$} \\
\hline & & $\begin{array}{l}\text { Субшкала } \\
\text { действия }\end{array}$ & $\begin{array}{l}\text { Субшка- } \\
\text { ла пути }\end{array}$ & $\begin{array}{l}\text { 0бщая } \\
\text { шкала }\end{array}$ & & \\
\hline $\begin{array}{l}\text { Бакалавры/ } \\
\text { магистры }\end{array}$ & 0,844 & 0,990 & 0,882 & 0,931 & 0,791 & 0,563 \\
\hline
\end{tabular}

Очевидно, что различия у магистров и бакалавров в ощущении субъективного благополучия отразились по всем критериям. Превосходство показателей в уровне субъективного благополучия у магистров по сравнению с бакалаврами мы связываем с осознанностью выбора своей профессионально-учебной деятельности у магистров, их самооценкой и самоощущением.

Первой рассматриваемой методикой является «Шкала субъективного счастья». Показатели по данной шкале представляют высокую степень различия ( $>>0.5)$, что говорит о том, что счастье как показатель психического благополучия сильно отличается для двух групп студентов, начиная с самого понимания благополучия.

Далее мы акцентировали внимание на показателях, полученных по шкале надежды. Данная шкала состоит из трех субшкал - Действие, Путь, Общая шкала надежды. По шкале «Действие», которая отвечает за благоприятные эмоции, вызванные удовлетворением своей деятельностью, виден самый высокий уровень различия ( $>>0.5)$. Достаточно высокое различие в группах и по шкале «Путь», которая направлена на исследование отношения к постановке целей и путей ее достижения. Рассматривая показатели общей шкалы надежды, можно убедиться в наличии высоких показателей, что говорит о хорошей корреляции шкалы надежды и ее субшкал.

Шкала «Общая удовлетворенность жизнью», направленная на измерение когнитивной составляющей, снова показывает высокие значения различий. Таким образом, по результатам анализа всех показателей, из которых строится субъективное благополучие, можно с твердой уверенностью утверждать, что между студентами-бакалаврами и студентами-магистрами в данном вопросе имеются ярко выраженные различия, причиной которой являются различные ценностные ориентации и разные виды преобладающей деятельности.

Кроме того, в ходе исследования сравнивалась успеваемость между обеими группами. Сравнение проводилось между процентным соотношением оценки «отлично» ко всем остальным оценкам, полученным в ходе зимней сессии. По данному критерию имеется небольшое различие ( $>0.5)$, и магистры показывают в среднем более высокие показатели. Связано это с тем, что для магистров подобная форма учебной деятельности является уже хорошо знакомой и они намного лучше, чем бакалавры, понимают способы достижения поставленных в процессе учебы целей.

Для более детального изучения мы проанализировали корреляционные связи субъективного благополучия и академической успеваемости с использованием критерия Спирмена. Данные нашего исследования отражены в таблице 3.

Результаты исследования убедительно доказывают, что субшкала пути и общая шкала надежды достаточно тесно коррелируют с академической успеваемостью, однако шкала субъективного счастья не показывает такой связи. Данные результаты говорят о том, что 
Таблица 3

Значения корреляции, показатели уровня удовлетворенности жизнью, субъективного счастья, надежды и успеваемости в группе студентов-бакалавров ( $\mathrm{N}=36)$

\begin{tabular}{|c|c|c|c|c|c|c|}
\hline \multirow[t]{2}{*}{ Показатель } & \multirow{2}{*}{\begin{tabular}{|c|} 
Шкала \\
субъ- \\
ективного \\
счастья \\
\end{tabular}} & \multicolumn{3}{|c|}{ Шкала надежды } & \multirow{2}{*}{$\begin{array}{l}\text { Шкала удов- } \\
\text { летворенно- } \\
\text { сти жизнью }\end{array}$} & \multirow{2}{*}{$\begin{array}{c}\text { \% оценок «от- } \\
\text { лично» в экза- } \\
\text { менационных } \\
\text { показателях }\end{array}$} \\
\hline & & $\begin{array}{l}\text { Субшка- } \\
\text { ла дей- } \\
\text { ствия }\end{array}$ & $\begin{array}{l}\text { Суб- } \\
\text { шкала } \\
\text { пути }\end{array}$ & $\begin{array}{l}\text { Общая } \\
\text { шкала }\end{array}$ & & \\
\hline $\begin{array}{l}\text { Шкала субъективного } \\
\text { счастья }\end{array}$ & 1 & 0,4 & $-0,1$ & 0,2 & 0,7 & 0,3 \\
\hline Субшкала действия & & 1 & 0,7 & 0,9 & 0,5 & 0,5 \\
\hline Субшкала пути & & & 1 & 0,9 & 0,4 & 0,5 \\
\hline 0бщая шкала & & & & 1 & 0,6 & 0,7 \\
\hline $\begin{array}{l}\text { Шкала удовлетворенно- } \\
\text { сти жизнью }\end{array}$ & & & & & 1 & 0,4 \\
\hline $\begin{array}{l}\text { \% оценок «отлично» в } \\
\text { экзаменационных по- } \\
\text { казателях }\end{array}$ & & & & & & 1 \\
\hline
\end{tabular}

в вопросах взаимосвязи субъективного благополучия и академической успеваемости у бакалавров имеется связь лишь по шкале надежды и по всем субшкалам данной шкалы.

Сравнивая картину взаимосвязи субъективного благополучия и академической успеваемости в группе магистров, наблюдается похожая картина, но мы видим, что вся триада субшкал по шкале надежды у магистров обнаруживает более тесную связь, чем у бакалавров ( $>>0.5)$. Результаты исследования представлены в таблице 4.

Таблица 4

Значения корреляции, показатели уровня удовлетворенности жизнью, субъективного счастья, надежды и успеваемости в группе студентов-магистров ( $\mathrm{N}=34)$

\begin{tabular}{|c|c|c|c|c|c|c|}
\hline \multirow[b]{2}{*}{ Показатель } & \multirow{2}{*}{$\begin{array}{c}\text { Шкала субъ- } \\
\text { ективного } \\
\text { счастья }\end{array}$} & \multicolumn{3}{|c|}{ Шкала надежды } & \multirow{2}{*}{$\begin{array}{l}\text { Шкала удов- } \\
\text { летворенно- } \\
\text { сти жизнью } \\
\end{array}$} & \multirow{2}{*}{$\begin{array}{l}\text { \% оценок «отлич- } \\
\text { но» в экзаменаци- } \\
\text { онных показателях }\end{array}$} \\
\hline & & $\begin{array}{l}\text { Субшкала } \\
\text { действия }\end{array}$ & $\begin{array}{l}\text { Субшка- } \\
\text { ла пути }\end{array}$ & $\begin{array}{l}\text { Общая } \\
\text { шкала }\end{array}$ & & \\
\hline $\begin{array}{l}\text { Шкала субъ- } \\
\text { ективного } \\
\text { счастья } \\
\end{array}$ & 1 & 0,4 & 0,4 & 0,4 & 0,7 & 0,4 \\
\hline $\begin{array}{l}\text { Субшкала } \\
\text { действия }\end{array}$ & & 1 & 0,6 & 0,9 & 0,3 & 0,8 \\
\hline $\begin{array}{l}\text { Субшкала } \\
\text { пути }\end{array}$ & & & 1 & 0,9 & 0,5 & 0,7 \\
\hline 0бщая шкала & & & & 1 & 0,3 & 0,8 \\
\hline $\begin{array}{l}\text { Шкала удов- } \\
\text { летворенно- } \\
\text { сти жизнью } \\
\end{array}$ & & & & & 1 & 0,2 \\
\hline $\begin{array}{l}\text { \% оценок «от- } \\
\text { лично» } \\
\text { в экзамена- } \\
\text { ционных по- } \\
\text { казателях }\end{array}$ & & & & & & 1 \\
\hline
\end{tabular}

Самая высокая взаимосвязь субъективного благополучия и академической успеваемости обнаруживается со шкалой действия. Так как магистры ощущают себя уже достаточно само- 
достаточными в учебно-профессиональном плане, то они уверены в успешности достижения поставленной цели.

Высокая корреляция субшкалы пути и общей шкалы надежды говорит о том, что студенты-магистры могут не просто ставить перед собой цели, но и достигать их.

В результате проведенного исследования были установлены следующие выводы: уровень субъективного благополучия у студентов-магистров выше по всем исследуемым критериям, чем уровень субъективного благополучия у студентов-бакалавров.

В результате проведенного итогового исследования с помощью ранговой корреляции Спирмена было установлено, что у магистров теснота связи с академической успеваемостью выше, чем у бакалавров. Корреляции успеваемости и шкалы субъективного счастья косвенно говорят о том, что самоощущение магистров более связаны с их успешностью в учебной деятельности.

На данном этапе работы мы проанализировали также наличие статистически значимых связей между показателями шкал. Нами намеренно взята для анализа именно выборка бакалавров, так как для них в отличие от магистров учебно-профессиональная деятельность является новой, что вызывает особый научный интерес. Показатели взаимосвязи отображены в таблице 5 .

Таблица 5

Значения корреляции показателей методик уровня благополучия, субъективного счастья, надежды и успеваемости у студентов 1 и 2 курсов

\begin{tabular}{|l|c|c|}
\hline \multicolumn{1}{|c|}{ Показатель } & 1 курс & 2 курс \\
\hline Шкала субъективного счастья & 0 & $-0,3$ \\
\hline Субшкала действия & 0,5 & 0,4 \\
\hline Субшкала пути & 0,7 & 0,1 \\
\hline Общая шкала надежды & 0,7 & 0,2 \\
\hline Шкала удовлетворенности жизнью & $-0,3$ & $-0,2$ \\
\hline
\end{tabular}

У респондентов первого года обучения статистически значимые связи выявились между успеваемостью и показателями по шкалам действия $(k=0,5)$, пути $(k=0,7)$ и надежды $(k=0,7)$. Для студентов второго года обучения связь средней тесноты $(\kappa=0,4)$ обнаружилась только для показателей по шкале действия. Таким образом, выяснилось, какие именно показатели в большей степени влияют на качество учебной деятельности для студентов первого года обучения, и можно утверждать, что студенты-бакалавры 1 курса обнаруживают большую взаимосвязь с академической успеваемостью по шкале надежды, чем студенты-бакалавры 2 курса.

0бсуждение. Результаты данного исследования представлены в докладе «Взаимосвязь субъективного благополучия и академической успеваемости у студентов» на IV Международной научно-практической конференции «Российская наука: тенденции и возможности», которая прошла в Таганроге 30 января 2020 года.

Заключение. Таким образом, выбранные гипотезы были подтверждены частично.

Взаимосвязь уровня субъективного благополучия и академической успеваемости у студентов обеих ступеней образования (бакалавриат, магистратура) независимо от их курса обучения зависит только от уровня надежды и не зависит от уровня субъективного счастья и удовлетворенности жизнью.

Не установлено подтверждения наличия гендерных различий студентов для понимания уровня их субъективного благополучия.

Выявлены значимые различия по всем критериям уровня субъективного благополучия между магистрами и бакалаврами.

Установлены различия в уровне субъективного благополучия между студентами бакалавриата первых и вторых курсов: уровень счастья и надежды у респондентов-первокурсников 
несколько выше, чем у второкурсников. Зато студенты второго курса в большей степени уверены в положительном результате своей деятельности и удовлетворены жизнью.

\section{Список литературы}

1. Аргайл М. Психология счастья. 2-е изд. СПб.: Питер, 2003. 271 с.

2. Бабанова Е.Д. Категории счастья и успеха в исследованиях позитивной психологии // Научный поиск. 2014. № 3.

3. Бонивелл И. Ключи к благополучию: Что может позитивная психология / пер. с англ. М. Бабичевой. М.: Время, 2009. 192 с.

4. Бочкарева М.В. Становление системы личностно-развивающего сопровождения студентов: электронный справочник. URL: http://www.informio.ru/publications/id3822/ (дата обращения: 22.12.2019).

5. Джидарьян И.А. Счастье и его типологические характеристики. М., 2000. 198 с.

6. Куликов Л.В. Здоровье и субъективное благополучие // Психология здоровья: коллективная монография / под ред. Г.С. Никифос. СПб.: Изд-во СПбГУ, 2000. С. 37-38.

7. Леонтьев Д.А. Личностный потенциал: структура и диагностика / под ред. Д.А. Леонтьева. М.: Смысл, 2011. 680 с.

8. Майерс Д. Социальная психология. СПб.: Питер, 2008. 794 с.

9. Муздыбаев К. Оптимизм и пессимизм личности // Социологические исследования. 2003. № 12. С. 87-96.

10. Перре М. Клиническая психология: учеб. пособие / под ред. М. Перре, У. Баумана. СПб.: Питер, 2002. 965 с.

11. Петровский А.В. Личность. Деятельность. Коллектив. М.: Политиздат, 1982. 255 с.

12. Психодиагностика в позитивной психологии: учеб.-метод. пособие / С.П. Елшанский, А.Ф. Ануфриев, 3.Ф. Камалетдинова, О.Е. Сапарин, Д.В. Семёнов. М.: МПГУ, 2016.

13. Психодиагностические ресурсы позитивной психологии: учеб.-метод. пособие / С.П. Елшанский, А.Ф. Ануфриев, З.Ф. Камалетдинова, 0.Е. Сапарин, Д.В. Семёнов. М.: МПГУ, 2016.

14. Роботова А.С. Оптимистический смысл деятельности преподавателя высшей школы // Высшее образование в России. 2018. № 2 (220). С. 66-77.

15. Стресс во время учебы у студентов. URL: https://psyhoday.ru/stress/faktory-v-processeucheby-studentov.html (дата обращения: 15.12.2019).

16. Сычёв 0.А. Психология оптимизма: учеб.-метод. пособие к спецкурсу. Бийск: БПГУ им. В.М. Шукшина, 2008. 69 с.

17. Тарасенко Л.В. Динамика профессиональных ожиданий за период ожидания в вузе // Науки об образовании. 2017. № 9.

18. Фадеева Т.Ю. Личностные факторы надежды // Социальная психология личности и акмеология: матер. Междунар. науч.-практ. конф.: сб. / под ред. Р.М. Шамионова, М.А. Кленовой. М.: Перо, 2018.

19. Шаповаленко И.В. Психология развития и возрастная психология: учебник для бакалавров. 2-е изд., перераб. и доп. М.: Юрайт, 2012. С. 445-447.

20. Diener E. Subjective well-being // Psychological Bulletin. 1984. No. 95.

\section{References}

1. Argajl M. Psikhologiya schast'ya. 2-e izd. SPb.: Piter, 2003. $271 \mathrm{s.}$

2. Babanova E.D. Kategorii schast'ya i uspekha $v$ issledovaniyakh pozitivnoj psikhologii // Nauchnyj poisk. 2014. № 3.

3. Bonivell I. Klyuchi k blagopoluchiyu: CHto mozhet pozitivnaya psikhologiya / per. s angl. M. Babichevoj. M.: Vremya, 2009. $192 \mathrm{s.}$

4. Bochkareva M.V. Stanovlenie sistemy lichnostno-razvivayushchego soprovozhdeniya studentov: elektronnij spravochnik. URL: http://www.informio.ru/publications/id3822/ (data obrashcheniya: 22.12.2019).

5. Dzhidar'yan I.A. Schast'e i ego tipologicheskie kharakteristiki. M., 2000. 198 c.

6. Kulikov L.V. Zdorov'e i sub"ektivnoe blagopoluchie // Psikhologiya zdorov'ya: kollektivnaya monografiya / pod red. G.S. Nikifos. SPb.: Izd-vo SPbGU, 2000. S. 37-38.

7. Leont'ev D.A. Lichnostnyj potencial: struktura i diagnostika / pod red. D.A. Leont'eva. M.: Smysl, 2011. $680 \mathrm{~s}$.

8. Majers D. Social'naya psikhologiya. SPb.: Piter, 2008. 794 C.

9. Muzdybaev K. Optimizm i pessimizm lichnosti // Sociologicheskie issledovaniya. 2003. № 12. S. $87-96$. 
10. Perre M. Klinicheskaya psikhologiya: ucheb. posobie / pod red. M. Perre, U. Baumana. SPb.: Piter, 2002. 965 s.

11. Petrovskij A.V. Lichnost'. Deyatel'nost'. Kollektiv. M.: Politizdat, 1982. 255 s.

12. Psikhodiagnostika $v$ pozitivnoj psikhologii: ucheb.-metod. posobie / S.P. Elshanskij, A.F. Anufriev, Z.F. Kamaletdinova, O.E. Saparin, D.V. Semyonov. M.: MPGU, 2016.

13. Psikhodiagnosticheskie resursy pozitivnoj psikhologii: ucheb.-metod. posobie / S.P. Elshanskij, A.F. Anufriev, Z.F. Kamaletdinova, 0.E. Saparin, D.V. Semyonov. M.: MPGU, 2016.

14. Robotova A.S. Optimisticheskij smysl deyatel'nosti prepodavatelya vysshej shkoly // Vysshee obrazovanie v Rossii. 2018. № 2 (220). S. 66-77.

15. Stress vo vremya ucheby u studentov. URL: https://psyhoday.ru/stress/faktory-v-processeucheby-studentov.html (data obrashcheniya: 15.12.2019).

16. Sychyov 0.A. Psikhologiya optimizma: ucheb.-metod. posobie k speckursu. Bijsk: BPGU im. V.M. Shukshina, 2008. $69 \mathrm{s.}$

17. Tarasenko L.V. Dinamika professional'nykh ozhidanij za period ozhidaniya v vuze // Nauki ob obrazovanii. 2017. № 9.

18. Fadeeva T.Yu. Lichnostnye faktory nadezhdy // Social'naya psikhologiya lichnosti i akmeologiya: mater. Mezhdunar. nauch.-prakt. konf.: sb. / pod red. R.M. Shamionova, M.A. Klenovoj. M.: Pero, 2018.

19. Shapovalenko I.V. Psikhologiya razvitiya i vozrastnaya psikhologiya: uchebnik dlya bakalavrov. 2-e izd., pererab. i dop. M.: Yurajt, 2012. S. 445-447.

20. Diener E. Subjective well-being // Psychological Bulletin. 1984. No. 95.

\section{Библиографическое описание статьи / Reference to article}

Петрова Е.А., Горячева А.Б. Сравнительный анализ субъективного благополучия студентов с разной академической успеваемостью в зависимости от ступени обучения // Ученые записки Российского государственного социального университета. Т. 19. 2020. № 1 (154). C. 66-74. DOI: 10.17922/2071-5323-2020-19-1-66-74 (Библиографическое описание coгласно российским стандартам).

Petrova E.A., Goryacheva A.B. Sravnitel'nyj analiz sub"ektivnogo blagopoluchiya studentov $s$ raznoj akademicheskoj uspevaemost'yu v zavisimosti ot stupeni obucheniya // Uchenye zapiski Rossijskogo gosudarstvennogo social'nogo universiteta. T. 19. 2020. № 1 (154). S. 66-74. D0I: 10.17922/2071-5323-2020-19-1-66-74 (Reference in Roman script).

Petrova, E.A. \& Goryacheva, A.B. (2020) Comparative Analysis of the Subjective Well-Being of Students with Different Academic Achievements in the Dependence of the Level of Study, Scientific Notes of Russian State Social University. Vol. 19. No. 1 (154). P. 66-74. D0I: 10.17922/2071-5323-2020-19-1-66-74 (International bibliographic description). 


\title{
В.Н. Феофанов,
}

канд. психол. наук, доцент, доцент кафедры психологии труда и специальной

психологии, Российский государственный социальный университет, Москва.

V.N. Feofanov,

candidate of psychological sciences, associate professor, associate professor

of the department of labor psychology and special psychology,

Russian State Social University, Moscow.

E-mail: v-feofanov@yandex.ru

\section{Особенности личности специалиста, работающего с детьми с расстройствами аутистического спектра (часть 2$)^{1}$}

\author{
Personality Features of a Specialist Working with Children \\ with Autism Spectrum Disorders (Part 2)
}

Дата поступления
10.12.2019

Аннотация: во второй части статьи автор описывает специфику личностных качеств специалиста, работающего с детьми с расстройствами аутистического спектра, и предлагает рекомендации для абитуриентов и студентов первых курсов, обучающихся по направлению подготовки «Специальное (дефектологическое) образование», по формированию личностных качеств и представлений о функционале специалистов, работающих с детьми с расстройствами аутистического спектра.

Annotation: in the second part of the article the author describes the personal qualities' specifics of a specialist working with children with autism spectrum disorders and offers recommendations for applicants and first-year students studying in the direction of training "Special (defectological) education" on the formation of personal qualities and ideas about the functionality of specialists working with children with autism spectrum disorders.

Ключевые слова: дети в инклюзивных группах, нейротипичные дети, расстройства аутистического спектра, специалисты, черты личности.

Key words: children in inclusive groups, neurotypical children, autism spectrum disorders, specialists, personality traits.

Для более точной проверки гипотезы о том, что специалисты, работающие с детьми с расстройства аутистического спектра (РАС), наиболее способны к эмоциональному отклику, менее тревожны, менее агрессивны и враждебны, а также более толерантны, чем их коллеги, работающие в разных условиях с разным контингентом детей, воспользуемся одним из методов математической статистики («U-критерий Манна-Уитни»).

В таблице 1 представлены результаты сравнительного анализа показателей уровня эмоционального отклика по опроснику А. Меграбяна и Н. Эпштейна у респондентов в среднем значении.

${ }^{1}$ Начало см.: Феофанов В.Н. Особенности личности специалиста, работающего с детьми с расстройствами аутистического спектра (часть 1) // Ученые записки Российского государственного социального университета. Т. 18. 2019. № 4 (153). С. 100-108. 
Сравнительная характеристика уровня эмоционального отклика у специалистов, работающих в разных условиях и с разным контингентом детей

\begin{tabular}{|l|c|c|}
\hline \multicolumn{1}{|c|}{ Сравниваемые группы } & $\mathbf{X}$ & $\mathbf{U}_{\text {зпп }}$ \\
\hline Специалисты, работающие с детьми с РАС & 74,71 & 228,0 \\
\cline { 1 - 2 } Специалисты, работающие с нейротипичными детьми & 73,76 & \\
\cline { 1 - 2 } Специалисты, работающие с детьми с РАС & 74,71 & \multirow{2}{*}{253,0} \\
\cline { 1 - 2 } Специалисты, работающие с детьми в инклюзивных группах & 73,69 & \\
\cline { 1 - 2 } Специалисты, работающие с нейротипичными детьми & 73,76 & \multirow{2}{*}{228,5} \\
\cline { 1 - 2 } Специалисты, работающие с детьми в инклюзивных группах & 73,69 & \\
\hline
\end{tabular}

Результаты, полученные при применении U-критерия Манна-Уитни, показали, что группы не имеют статистически значимые различия в уровне эмоционального отклика. Это означает, что респонденты из трех групп обладают высоким уровнем эмпатии. Тем не менее обращает на себя внимание то, что средний показатель респондентов из группы специалистов, работающих с детьми с PAC $(x=74,71)$, больше средних показателей респондентов из группы специалистов, работающих с нейротипичными детьми $(\mathrm{x}=73,76)$, а также из группы специалистов, работающих с детьми в инклюзивных группах (x=73,69).

Представим результаты сравнительного анализа по шкале ситуативной тревожности психодиагностической методики «Самооценка уровня тревожности Ч.Д. Спилбергера и Ю.Л. Ханина» в таблице 2.

Таблица 2

Эмпирические значения и показатель достоверности различий ситуативной тревожности у специалистов, работающих в разных условиях и с разным контингентом детей

\begin{tabular}{|c|c|c|}
\hline Сравниваемые группы & $\mathbf{X}$ & $\mathbf{U}_{\text {эпм }}$ \\
\hline Специалисты, работающие с детьми с РАС & 54,28 & \multirow[t]{2}{*}{$307,5^{*}$} \\
\hline Специалисты, работающие с нейротипичными детьми & 52,09 & \\
\hline Специалисты, работающие с детьми с РАC & 54,28 & \multirow[t]{2}{*}{299,0} \\
\hline Специалисты, работающие с детьми в инклюзивных группах & 53,65 & \\
\hline Специалисты, работающие с нейротипичными детьми & 52,09 & \multirow[t]{2}{*}{278,0} \\
\hline Специалисты, работающие с детьми в инклюзивных группах & 53,65 & \\
\hline
\end{tabular}

Примечание: * $-p<0,05$.

Результаты, полученные при применении U-критерия Манна-Уитни, показали, что специалисты всех трех групп не имеют статистически значимые различия по показателям ситуативной тревожности. Это означает, что респонденты из двух групп обладают высоким уровнем ситуативной тревожности. Тем не менее можно констатировать, что специалисты, работающие с детьми с РАС, достоверно обладают более высоким уровнем ситуативной тревожности, чем специалисты, работающие с нейротипичными детьми.

Представим результаты сравнительного анализа по шкале личностной тревожности психодиагностической методики «Самооценка уровня тревожности Ч.Д. Спилбергера и Ю.Л. Ханина» в таблице 3.

Результаты, полученные при применении U-критерия Манна-Уитни, показали, что специалисты, работающие с детьми с РАC, обладают достоверно более низким уровнем личностной тревожности, чем специалисты, работающие с нейротипичными детьми.

Специалисты, работающие с детьми с РАС, и специалисты, работающие с детьми в инклюзивных группах, не имеют статистически значимые различия по показателям личностной 
Эмпирические значения и показатели достоверности различий личностной тревожности у специалистов, работающих в разных условиях и с разным контингентом детей

\begin{tabular}{|l|c|c|}
\hline \multicolumn{1}{|c|}{ Сравниваемые группы } & $\mathbf{X}$ & $\mathbf{U}_{\text {эпм }}$ \\
\hline Специалисты, работающие с детьми с РАС & 51,90 & \multirow{2}{*}{$93,5^{* * *}$} \\
\hline Специалисты, работающие с нейротипичными детьми & 56,52 & \\
\hline Специалисты, работающие с детьми с РАС & 51,90 & \multirow{2}{*}{176,5} \\
\hline Специалисты, работающие с детьми в инклюзивных группах & 53,82 & \\
\hline Специалисты, работающие с нейротипичными детьми & 56,52 & \multirow{2}{*}{$154,0^{*}$} \\
\hline Специалисты, работающие с детьми в инклюзивных группах & 53,82 & \\
\hline
\end{tabular}

Примечание: * $-p<0,05, * * *-p<0,001$.

тревожности. Это означает, что респонденты двух групп обладают высоким уровнем личностной тревожности.

Специалисты, работающие с нейротипичными детьми, обладают достоверно более высоким уровнем личностной тревожности, чем специалисты, работающие с детьми в инклюзивных группах.

Представим результаты сравнительного анализа по индексу враждебности в психодиагностической методике «Диагностика показателей и форм агрессивного поведения А. Басса - А. Дарки» в таблице 4.

Таблица 4

Эмпирические значения и показатели достоверности различий индекса враждебности у специалистов, работающих в разных условиях и с разным контингентом детей

\begin{tabular}{|l|c|c|}
\hline \multicolumn{1}{|r|}{ Сравниваемые группы } & $\mathbf{X}$ & \multirow{2}{*}{$\mathbf{U}_{\text {эпм }}$} \\
\hline Специалисты, работающие с детьми с РАС & 17,71 & \multirow{2}{*}{$23,5^{* * *}$} \\
\cline { 1 - 2 } Специалисты, работающие с нейротипичными детьми & 47,16 & \\
\hline Специалисты, работающие с детьми с РАС & 17,71 & \multirow{2}{*}{$49,0^{* * *}$} \\
\cline { 1 - 2 } Специалисты, работающие с детьми в инклюзивных группах & 36,08 & \\
\hline Специалисты, работающие с нейротипичными детьми & 47,16 & \multirow{2}{*}{$153,5^{*}$} \\
\cline { 1 - 2 } Специалисты, работающие с детьми в инклюзивных группах & 36,08 & \\
\hline
\end{tabular}

Примечание: * $-p<0,05,{ }^{* * *}-p<0,001$.

Результаты, полученные при применении U-критерия Манна-Уитни, показали, что специалисты, работающие с детьми с РАС, достоверно менее враждебны, чем специалисты, paботающие с нейротипичными детьми.

Специалисты, работающие с детьми с РАC, достоверно менее враждебны, чем спещиалисты, работающие с детьми в инклюзивных группах.

Специалисты, работающие с детьми в инклюзивных группах, обладают достоверно более низким уровнем враждебности, чем специалисты, работающие с детьми в инклюзивных групnах.

Представим результаты сравнительного анализа по индексу агрессивности в психодиагностической методике «Диагностика показателей и форм агрессивного поведения А. Басса - А. Дарки» в таблице 5.

Результаты, полученные при применении U-критерия Манна-Уитни, показали, что специалисты, работающие с детьми с РАС, достоверно менее агрессивны, чем специалисты, работающие с нейротипичными детьми. 
Эмпирические значения и показатели достоверности различий индекса агрессивности у специалистов, работающих в разных условиях и с разным контингентом детей

\begin{tabular}{|l|c|c|}
\hline \multicolumn{1}{|c|}{ Сравниваемые группы } & $\mathbf{X}$ & $\mathbf{U}_{\text {зпм }}$ \\
\hline Специалисты, работающие с детьми с РАС & 27,286 & \multirow{2}{*}{$50,5^{* * *}$} \\
\hline Специалисты, работающие с нейротипичными детьми & 49,286 & \\
\hline Специалисты, работающие с детьми с РАС & 27,28 & \multirow{2}{*}{$144,0^{*}$} \\
\hline Специалисты, работающие с детьми в инклюзивных группах & 37,83 & \\
\hline Специалисты, работающие с нейротипичными детьми & 49,28 & \multirow{2}{*}{$145,5^{*}$} \\
\cline { 1 - 2 } Специалисты, работающие с детьми в инклюзивных группах & 37,83 & \\
\hline
\end{tabular}

Примечание: ${ }^{*}-p<0,05, * * *-p<0,001$.

Специалисты, работающие с детьми с РАС, достоверно менее агрессивны, чем специалисты, работающие с детьми в инклюзивных группах.

Специалисты, работающие в инклюзивных группах, достоверно менее агрессивны, чем специалисты, работающие с нейротипичными детьми.

Представим результаты сравнительного анализа показателей коммуникативной толерантности по психодиагностической методике «0просник коммуникативной толерантности В.В. Бойко» в таблице 6.

Таблица 6

Эмпирические значения и показатели достоверности различий коммуникативной толерантности у специалистов, работающих в разных условиях и с разным контингентом детей

\begin{tabular}{|c|c|c|}
\hline Сравниваемые группы & $\mathbf{x}$ & $\mathbf{U}_{\text {эпм }}$ \\
\hline Специалисты, работающие с детьми с РАC & 21,95 & \multirow[t]{2}{*}{$36,5 * * *$} \\
\hline Специалисты, работающие с нейротипичными детьми & 47,14 & \\
\hline Специалисты, работающие с детьми с РАС & 21,95 & \multirow[t]{2}{*}{$111,5^{* *}$} \\
\hline Специалисты, работающие с детьми в инклюзивных группах & 34,08 & \\
\hline Специалисты, работающие с нейротипичными детьми & 47,14 & \multirow[t]{2}{*}{123,0 ** } \\
\hline Специалисты, работающие с детьми в инклюзивных группах & 34,087 & \\
\hline
\end{tabular}

Примечание: ${ }^{* *}-p<0,01,{ }^{* * *}-p<0,001$.

Результаты, полученные при применении U-критерия Манна-Уитни, показали, что специалисты, работающие с детьми с PAC, достоверно обладают более высоким уровнем коммуникативной толерантности, чем специалисты, работающие с нейротипичными детьми.

Специалисты, работающие с детьми с РAC, обладают более высоким уровнем коммуникативной толерантности, чем специалисты, работающие с детьми в инклюзивных группах.

Специалисты, работающие с нейротипичными детьми, обладают более низким уровнем коммуникативной толерантности, чем специалисты, работающие с детьми в инклюзивных групnах.

Таким образом, проанализировав результаты, полученные с помощью U-критерия Манна-Уитни, можно сделать вывод, что статистически значимые различия присутствуют среди следующих показателей:

а) ситуативной тревожности у спещиалистов, работающих с детьми с РАС, и специалистов, работающих с нейротипичными детьми $(\mathrm{p}<0,05)$;

б) личностной тревожности у специалистов, работающих с детьми с РАС, и специалистов, работающих с нейротипичными детьми $(\mathrm{p}<0,001)$; 
в) личностной тревожности у специалистов, работающих с нейротипичными детьми, и специалистов, работающих с детьми в инклюзивных группах $(\mathrm{p}<0,05)$.

г) индекса враждебности у специалистов, работающих с детьми с РАC, и специалистов, работающих с нейротипичными детьми ( $<<0,001)$;

д) индекса враждебности у специалистов, работающих с детьми с РАC, и специалистов, работающих с детьми в инклюзивных группах $(\mathrm{p}=<0,001)$;

е) индекса враждебности у специалистов, работающих с нейротипичными детьми, и специалистов, работающих с детьми в инклюзивных группах $(\mathrm{p}<0,05)$;

ж) индекса агрессивности у специалистов, работающих с детьми с PAC, и показателей респондентов из группы специалистов, работающих с нейротипичными детьми $(p<0,001)$;

3) индекса агрессивности у специалистов, работающих с детьми с РАС, и специалистов, работающих с детьми в инклюзивных группах $(\mathrm{p}=<0,05)$;

и) индекса агрессивности у специалистов, работающих с нейротипичными детьми, и специалистов, работающих с детьми в инклюзивных группах $(\mathrm{p}<0,05)$;

к) показателя коммуникативной толерантности у специалистов, работающих с детьми с PAC, и показателей респондентов из группы специалистов, работающих с нейротипичными детьми $(\mathrm{p}<0,001)$;

л) показателя коммуникативной толерантности у специалистов, работающих с детьми с РАС, и специалистов, работающих с детьми в инклюзивных группах $(\mathrm{p}=<0,01)$;

м) показателя коммуникативной толерантности у специалистов, работающих с нейротипичными детьми, и специалистов, работающих с детьми в инклюзивных группах $(p<0,01)$.

Обобщение эмпирических фактов, касающихся определения особых личностных качеств специалистов, работающих в разных условиях и с разным контингентом детей, позволяет подтвердить гипотезу о том, что специалисты, работающие с детьми с PAC, менее тревожны, менее агрессивны и враждебны, а также более толерантны, чем их коллеги, работающие в разных условиях с разным контингентом детей.

0бсуждение. Статистически значимые различия отсутствуют при сравнении трех групп респондентов по уровню эмоционального отклика. Это означает, что специалисты, работающие с детьми с РАС, специалисты, работающие с нейротипичными детьми, и специалисты, работающие с детьми в инклюзивных группах, обладают высоким уровнем развития эмпатии.

Анализ результатов исследования установил, что тревожность как актуальное состояние и свойство личности [2] характерна для респондентов трех групп. Вместе с тем специалисты, работающие с детьми с PAC, чаще переживают эмоциональный дискомфорт, напряжение, беспокойство, связанные с ожиданием неблагополучия, чем их коллеги, работающие в разных условиях с разным контингентом детей.

В ходе обработки результатов оказалось, что специалисты, работающие с нейротипичными детьми, чаще других специалистов имеют устойчивую склонность воспринимать угрозу своему «Я» в самых различных ситуациях и реагировать на эти ситуации повышением ситуативной тревожности [2]. Можно предположить, что у них ниже и порог чувствительности к разным стрессовым агентам, а также выше склонность к эмоциональным и невротическим срывам. Иными словами, повышенный уровень тревожности провоцирует существенные изменения в нервнопсихической сфере, отражается на здоровье самого специалиста и качестве его профессиональной деятельности, а также на поведении учащихся, с которыми он взаимодействует. Необходимо скорректировать условия профессиональной деятельности и отношения в ее процессе так, чтобы снизить напряженность, неизбежную в педагогическом труде, и перевести ее из деструктивного русла в напряженность увлекательного творческого сотрудничества [2].

Полученные результаты исследования показывают, что индекс враждебности как реакция, состоящая в том, что личность занимает в общем негативную позицию по отношению к окружающим, характерен для респондентов трех групп. Однако самые низкие показатели были получены в группе специалистов, работающих с детьми с РАС. Специалисты, работаю- 
щие с детьми в инклюзивных группах, а также специалисты, работающие с нейротипичными детьми, чаще испытывают ненависть к окружающим, чувство гнева на весь мир за действительные или мнимые страдания, демонстрируют недоверие и осторожность по отношению к людям, что затрудняет сотрудничество с детским контингентом [3]. Данные результаты можно считать подтверждением выдвинутой ранее гипотезы о том, что специалисты, работающие с детьми с PAC, менее враждебны, чем их коллеги, работающие в разных условиях с разным контингентом детей.

Сравнительный анализ показал, что индекс агрессивности [3], который определяется как реакция, проявляющаяся «внешне», активная по отношению к конкретным лицам, характеризует респондентов всех групп. Вместе с тем самые низкие показатели были получены в группе специалистов, работающих с детьми с РАС. Специалисты, работающие с детьми в инклюзивных группах, а также специалисты, работающие с нейротипичными детьми, чаще демонстрируют физическую, косвенную агрессию, раздражение и вербальную агрессию, что затрудняет сотрудничество, сознательную кооперацию, а также провоцирует конфликтность. Данные результаты можно считать подтверждением выдвинутой ранее гипотезы о том, что специалисты, работающие с детьми с РАС, менее агрессивны, чем их коллеги, работающие в разных условиях с разным контингентом детей.

В целом анализ результатов диагностики агрессивных и враждебных реакций личности на воздействие внешнего мира можно объяснить профессиональным выгоранием, ведь подобная работа требует частого включения в жизнь детей, эмоциональной отдачи. Профессиональное выгорание может выражаться в наличии негативных эмоций и поведенческих проявлений в виде агрессии, негативизма, аутизации [12], что частично объясняет полученные результаты.

Сравнительный анализ позволил выявить, что толерантность в общении, которая определяется как отношение личности к людям и показывает степень переносимости неприятных или неприемлемых психических состояний и качеств партнера по взаимодействию [1], диагностирована у респондентов всех групп. Однако самые низкие показатели были получены вновь в группе специалистов, работающих с детьми с РАС. У специалистов, работающих с детьми в инклюзивных группах, а также специалистов, работающих с нейротипичными детьми, чаще наблюдается нетерпимость к окружающим и присутствует высокая вероятность конфликтов. На наш взгляд, это личностное качество является действительно очень важным для специалистов, осуществляющих педагогическую деятельность в разных условиях с разным контингентом детей. Тем не менее данные результаты можно считать подтверждением выдвинутой ранее гипотезы о том, что специалисты, работающие с детьми с РАС, более толерантны, чем их коллеги, работающие в разных условиях с разным контингентом детей.

Заключение. Результаты эмпирического исследования показали, что специалисты, работающие с детьми с PAC, имеют определенные личностные черты, которые отличают специалистов, работающих непосредственно с детьми с РАС, от специалистов, работающих с детьми в инклюзивных группах, и от специалистов, работающих с нейротипичными детьми. Безусловно, специалист, работающий с детьми с РАС, должен обладать определенными компетенциями, инструментами, знанием коррекционных программ. Данные положения являются составной частью профессиональной компетенции специалиста. Кроме этого стоит уделить внимание и профессиональной готовности специалиста. На наш взгляд, очень важным аспектом в формировании профессиональной готовности является осведомленность абитуриентов и студентов начальных курсов о будущей профессии.

На основании полученных в результате проведения эмпирического исследования данных и анализа научной литературы [4-11; 13-20] мы можем разработать рекомендации для абитуриентов и студентов, обучающихся по направлению подготовки «Специальное (дефектологическое) образование». Данные рекомендации помогут в формировании личностных качеств и представлений о функционале специалистов, работающих с детьми с РАС. 
Стоит начать с утверждения: специалист, работающий с детьми с РАС, должен обладать определенными личностными качествами. Это обусловлено тем, что дети с РАС требуют особого внимания. Ведь именно они испытывают нарушения вербальной и невербальной коммуникации, социального взаимодействия, имеют ограниченный репертуар реакций, повторяющееся и стереотипное поведение. Часто такое состояние сопровождается и другими нарушениями. Данные положения усложняют взаимодействие с такими детьми, что, безусловно, отражается на коррекционной психолого-педагогической деятельности. Безусловно, специалист, работающий с детьми с РАС, не должен быть враждебным или агрессивным, ведь этот фактор может увеличить вероятность возникновения конфликтной ситуации, что в разы ухудшит отношения в диаде «педагог - обучающийся». Специалист должен обладать высоким уровнем развития эмпатии, что сделает его более открытым по отношению к детям с РАС, ведь коррекционная психолого-педагогическая деятельность специалиста действительно является необходимой для детей с РАС помощью и неким проводником в продуктивное будущее. На наш взгляд, чтобы осуществлять такую деятельность успешно, необходимо быть внимательным и чутким к состоянию детей с РАС, что невозможно без должного развития уровня эмпатии. Кроме того, очень важным является высокий уровень развития коммуникативной толерантности. Данное понятие включает в себя такие важные черты, как умение принимать индивидуальность оппонента, умение прощать другому человеку ошибки и терпимость к состоянию другого человека. Учитывая все особенности детей с РАС, это положение действительно является очень важным, ведь иногда ребенок не с первого раза может понять инструкцию, он медленнее справляется с определенными действиями, а в некоторых случаях даже может не идти на контакт. Эти особенности очень важно понимать и принимать.

Безусловно, если абитуриент или студент, обучающийся по направлению подготовки «Специальное (дефектологическое) образование», осознает, что не располагает этими качествами, может появиться желание отказаться от идеи получения соответствующего образования. В этом случае хочется посоветовать прислушаться к себе, пройти специальную профориентационную диагностику, которая поможет понять склонность личности к той или иной деятельности. А потом задать себе вопросы «Готов ли я помогать и принимать человека, готов ли я брать на себя ответственность за его будущее?». И если ответы положительные, то это будет прекрасной новостью, потому что в системе инклюзивного образования на одного подготовленного и квалифицированного специалиста станет больше.

Далее мы перейдем к описанию функций, которые выполняют разные специалисты, работающие в системе инклюзивного образования с детьми с РАС.

\section{Функции педагога-дефектолога.}

1. Создание адекватно организованной среды. Детям с РАС просто необходима адекватно организованная среда, ведь в основном такие дети живут с определенными стереотипами в поведении, нарушение которых может вызвать сильный стресс, чувство беспокойства и страха. Адекватно организованная среда помогает снизить данные негативные проявления и кроме этого помогает в организации и структурировании деятельности детей с РАС. Всё пространство необходимо разделить на несколько зон: зона обучения, зона отдыха и игровая зона.

2. Организация и визуализация времени. Необходимо планировать предстоящие моменты, регулярно чередовать события в жизни детей с РАС. Именно это помогает им ориентироваться во времени и понимать, когда та или иная деятельность произойдет. Таким образом, детям с РАС легче переживать происходящие события без чувства беспокойства и страха.

3. Структурирование видов деятельности. Большинство сверстников детей с РАС практически самостоятельно овладевают теми или иными повседневными действиями. Детей с РАС необходимо целенаправленно этому учить. По этой причине так важен структурный подход в их обучении. Безусловно, всё начинается с освоения продуктивной деятельности и навыков взаимодействия и продолжается получением навыков учебного поведения. 
4. Преодоление неравномерности в развитии. С помощью специальных методик и программ, методов и приемов обучения преодолевается барьер между детьми с РАС и их нейротипичными сверстниками. К данным методам можно отнести наглядные средства преподнесения материала, рациональное дозирование информации и т.д.

5. Организация режима коммуникативного общения. Необходимо построить вполне конкретную коммуникацию с детьми с РАС, стремиться к тому, чтобы она стала неотъемлемой частью в жизни таких детей. Необходимо подробно объяснять задания: что требуется от детей. Очень важно проговаривать произошедшие события и важные моменты жизни.

6. Социально-бытовая адаптация. Очень важным является закрепление полученных знаний и навыков, то есть существует необходимость переноса полученных навыков в реальную жизнь. В этом плане нужна непосредственная помощь от родителей детей с РАС.

\section{Функции психолога.}

1. Формирование отношений с другими детьми и взрослыми. Психолог помогает ребенку установить границы взаимодействия, ведь у некоторых детей с РАС могут появляться тенденции к симбиотическим отношениям, которые в некоторых случаях могут быть для них изматывающими. Кроме того, психолог помогает понять способы и приемы взаимодействия с окружающими.

2. Работа с семьями детей с РАС. Семьям детей с РАС бывает сложно принять реальность и научиться жить с тем, что на первый взгляд одаренный и талантливый ребенок не такой, как все. Для принятия реальности необходима ресурсная поддержка психолога.

3. Психологическая поддержка педагогов, работающих с детьми с РАС. Психолог и в этом случае выступает как ресурсный компонент, который, учитывая особенности детей с РАС, может направлять деятельность педагога в нужное русло.

\section{Функции логопеда.}

1. Работа над мелодическими и ритмическими компонентами речи детей с РАС. Данные компоненты непосредственно связаны с чтением. В связи со своими особенностями дети с РАС могут читать текст без соблюдения знаков, крайне монотонно, поэтому материал усваивается намного сложнее. Работа логопеда заключается в формировании навыков интонируемого и осознанного чтения.

2. Проведение коррекционной работы при наличии признаков фонетико-фонематического недоразвития речи.

3. Работа над коммуникативной стороной речи, умением работать в режиме диалога, отвечать на поставленные вопросы по существу, развитие у ребенка умения поддерживать диалог и даже инициировать его. Это достаточно серьезный аспект, с которым работает не только логопед, но и дефектолог.

\section{Функции социального педагога.}

1. Контроль и соблюдение прав всех детей в образовательном учреждении.

2. Выявление потребностей детей с РАС и их семей в социальной поддержке.

3. Установление взаимодействия с учреждениями, которые могут оказать социальную помощь семьям детей с РАС.

\section{Функции координатора по инклюзии (методиста).}

1. Организация процесса включения детей с РАС в образовательную среду.

2. Создание специальных условий для адаптации детей с РАС.

3. Выполнение роли основного помощника педагога в классе в решении организационных вопросов.

Функции педагога.

1. Осуществление непосредственно педагогической и коррекционно-педагогической деятельности.

2. Планирование интегрированных мероприятий с другими педагогами и специалистами. 
Это необходимо для решения проблем, которые могут возникать непосредственно с детьми с РАС или же с их родителями.

Стоит отметить, что эффективность данных рекомендаций не была нами определена, тем не менее, предполагается, что их использование будет способствовать формированию личностных качеств и представлений о функционале специалистов, работающих с детьми с РАС, у абитуриентов и студентов первых курсов, что, в свою очередь, поможет в развитии профессиональной готовности у будущих специалистов, в которых нуждается современная система образования.

Благодарности. Автор выражает благодарность и глубокую признательность руководству автономной некоммерческой организации «Центр реабилитации инвалидов детства “Наш солнечный мир”» в лице И.Л. Шпицберга и лично психологу И.В. Карпенковой за оказанную помощь при проведении данного исследования, а также Д.А. Матевосовой за сбор эмпирического материала и обработку данных.

\section{Список литературы}

1. Воробьева И.В. Феномен толерантности в контексте педагогического взаимодействия: автореф. дис. ... канд. психол. наук. Екатеринбург, 2006. 24 с.

2. Гульчевская Н.Е. Особенности профессиональной тревожности учителя в условиях образовательных инноваций: автореф. дис. ... канд. психол. наук. Ростов н/Д, 2004. 24 с.

3. Дикова В.В., Зеер Э.Ф. Педагогическая агрессия как профессионально обусловленная деформация учителя // Образование и наука. 2005. № 4 (34). С. 78-89.

4. Ильина А.В., Маковецкая Ю.Г. Социокультурные и профессиональные барьеры восприятия педагогами учащихся с расстройствами аутистического спектра // Вестник Академии энциклопедических наук. 2017. № 3 (28). С. 41-48.

5. Калинина Н.В. Адаптационное взаимодействие педагогов с инклюзивной образовательной средой // Инклюзивное образование: результаты, / под ред. С.В. Алехиной. М.: МГППУ, 2015. С. 177-181.

6. Кисляков П.А., Шмелева Е.А., Удодов А.Г. Методологические принципы социально-психологического обеспечения безопасности детей с ограниченными возможностями здоровья // Здоровьесберегающее и здоровьесозидающее образование в условиях реализации ФГОС нового поколения: матер. Всерос. науч. школы здоровья с междунар. участием: сб. Стерлитамак: Стерлитам. филиал Башкирского гос. ун-та, 2017. С. 185-189.

7. Комплексное сопровождение лиц с расстройствами аутистического спектра: матер. VIII Междунар. науч.-практ. конф.: науч.-практ. сб. / отв. ред. Е.А. Черенёва. Красноярск, 2015. 187 c.

8. Лавская Н.С. Особенности профессиональной деятельности педагога-дефектолога // Вестник Костромского государственного университета. Т. 18. 2012. № 3. С. 229-231.

9. Ларионова М.А. Некоторые аспекты профессионализма педагога в коррекционно-развивающей работе с детьми с расстройством аутистического спектра // Мир науки, культуры, образования. 2019. № 1 (74). С. 293-294.

10. Леонова И.В., Карпенкова И.В. Эффективные стратегии тьюторского сопровождения классным руководителем и воспитателем детей с РАС, способствующие развитию у них функциональной коммуникации // Бизнес. Образование. Право. 2019. № 2 (47). С. 375-388.

11. Мамайчук И.И. Помощь психолога детям с аутизмом. СПб.: Речь, 2007. 288 с.

12. Неруш Т.Г. Профессиональное выгорание как специфическая форма профессиональных деструкций // Известия Саратовского университета. 2012. № 12. С. 83-87.

13. Обучение детей с расстройствами аутистического спектра. Методические рекомендации для педагогов и специалистов сопровождения основной школы / отв. ред. С.В. Алехина; под общ. ред. Н.Я. Семаго. М.: МГППУ, 2012. 80 с.

14. Организация деятельности координатора по инклюзии в образовательном учреждении / ред. Т.Н. Гусева; сост. Т.П. Дмитриева. М.: Школьная книга, 2010. 80 с.

15. Пряжникова Е.Ю., Галкина Т.Э. Роль социальной работы с детьми с ранним детским аутизмом // Психологическая наука и образование. 2003. № 1. С. 92-99.

16. Семаго Н.Я., Соломахина Е.А. Психолого-педагогическое сопровождение ребенка с РАС // Аутизм и нарушения развития. Т. 15. 2017. № 1. С. 4-14. 
17. Сорокоумова С.Н., Ивенских И.В. Профилизация будущих педагогов начальной школы для системы инклюзивного образования // Проблемы современного педагогического образования. 2017. № 56-1. С. 367-373.

18. Сульженко 0.Ю. Формирование речевой коммуникации у детей с аутизмом (из опыта работы учителя-логопеда) // Аутизм и нарушения развития. 2010. № 1 (28). С. 21-26.

19. Угрюмова Н.А. Профессиональные компетенции педагога, работающего с детьми с расстройствами аутистического спектра // Педагогика XXI века: традиции и инновации: Bceрос. науч. конф. с междунар. участием: сб. науч. трудов / под ред. Н.В. Фединой. Липецк, 2018. С. 82-85.

20. Ястребова Л.А. Формирование профессионально значимых качеств будущих педагоговдефектологов: автореф. дис ... канд. пед. наук. Армавир, 2008. 167 с.

\section{References}

1. Vorob'eva I.V. Fenomen tolerantnosti v kontekste pedagogicheskogo vzaimodejstviya: avtoref. dis. ... kand. psikhol. nauk. Ekaterinburg, 2006. 24 s.

2. Gul'chevskaya N.E. Osobennosti professional'noj trevozhnosti uchitelya $v$ usloviyakh obrazovatel'nykh innovatsij: avtoref. dis. ... kand. psikhol. nauk. Rostov n/D, 2004. 24 s.

3. Dikova V.V., Zeer E.F. Pedagogicheskaya agressiya kak professional'no obuslovlennaya deformatsiya uchitelya // Obrazovanie i nauka. 2005. № 4 (34). S. 78-89.

4. Il'ina A.V., Makovetskaya Yu.G. Sotsiokul'turnye i professional'nye bar'ery vospriyatiya pedagogami uchashchikhsya s rasstrojstvami autisticheskogo spektra // Vestnik Akademii entsiklopedicheskikh nauk. 2017. № 3 (28). S. 41-48.

5. Kalinina N.V. Adaptatsionnoe vzaimodejstvie pedagogov $S$ inklyuzivnoj obrazovatel'noj sredoj // Inklyuzivnoe obrazovanie: rezul'taty, / pod red. S.V. Alekhinoj. M.: MGPPU, 2015. S. 177-181.

6. Kislyakov P.A., Shmeleva E.A., Udodov A.G. Metodologicheskie printsipy sotsial'nopsikhologicheskogo obespecheniya bezopasnosti detej s ogranichennymi vozmozhnostyami zdorov'ya // Zdorov'esberegayushchee i zdorov'esozidayushchee obrazovanie $v$ usloviyakh realizatsii FGOS novogo pokoleniya: mater. Vseros. nauch. shkoly zdorov'ya $\mathrm{S}$ mezhdunar. uchastiem: sb. Sterlitamak: Sterlitam. filial Bashkirskogo gos. un-ta, 2017. S. 185-189.

7. Kompleksnoe soprovozhdenie lits $s$ rasstrojstvami autisticheskogo spektra: mater. VIII Mezhdunar. nauch.-prakt. konf.: nauch.-prakt. sb. / otv. red. E.A. Cherenyova. Krasnoyarsk, 2015. $187 \mathrm{~s}$.

8. Lavskaya N.S. Osobennosti professional'noj deyatel'nosti pedagoga-defektologa // Vestnik Kostromskogo gosudarstvennogo universiteta. T. 18. 2012. № 3. S. 229-231.

9. Larionova M.A. Nekotorye aspekty professionalizma pedagoga $v$ korrektsionnorazvivayushchej rabote $\mathrm{s}$ det'mi s rasstrojstvom autisticheskogo spektra // Mir nauki, kul'tury, obrazovaniya. 2019. № 1 (74). S. 293-294.

10. Leonova I.V., Karpenkova I.V. Effektivnye strategii t'yutorskogo soprovozhdeniya klassnym rukovoditelem i vospitatelem detej s RAS, sposobstvuyushchie razvitiyu u nikh funktsional'noj kommunikatsii // Biznes. Obrazovanie. Pravo. 2019. № 2 (47). S. 375-388.

11. Mamajchuk I.I. Pomoshch' psikhologa detyam s autizmom. SPb.: Rech', 2007. $288 \mathrm{~s}$.

12. Nerush T.G. Professional'noe vygoranie kak spetsificheskaya forma professional'nykh destruktsij // Izvestiya Saratovskogo universiteta. 2012. № 12. S. 83-87.

13. Obuchenie detej s rasstrojstvami autisticheskogo spektra. Metodicheskie rekomendatsii dlya pedagogov i spetsialistov soprovozhdeniya osnovnoj shkoly / otv. red. S.V. Alekhina; pod obshch. red. N.Ya. Semago. M.: MGPPU, 2012. $80 \mathrm{~s}$.

14. Organizatsiya deyatel'nosti koordinatora po inklyuzii v obrazovatel'nom uchrezhdenii / red. T.N. Guseva; sost. T.P. Dmitrieva. M.: Shkol'naya kniga, 2010. $80 \mathrm{~s}$.

15. Pryazhnikova E.Yu., Galkina T.E. Rol' sotsial'noj raboty s det'mi s rannim detskim autizmom // Psikhologicheskaya nauka i obrazovanie. 2003. № 1. S. 92-99.

16. Semago N.Ya., Solomakhina E.A. Psikhologo-pedagogicheskoe soprovozhdenie rebenka s RAS // Autizm i narusheniya razvitiya. T. 15. 2017. № 1. S. 4-14.

17. Sorokoumova S.N., Ivenskikh I.V. Profilizatsiya budushchikh pedagogov nachal'noj shkoly dlya sistemy inklyuzivnogo obrazovaniya // Problemy sovremennogo pedagogicheskogo obrazovaniya. 2017. № 56-1. S. 367-373.

18. Sul'zhenko 0.Yu. Formirovanie rechevoj kommunikatsii u detej s autizmom (iz opyta raboty uchitelya-logopeda) // Autizm i narusheniya razvitiya. 2010. № 1 (28). S. 21-26. 
19. Ugryumova N.A. Professional'nye kompetentsii pedagoga, rabotayushchego s det'mi s rasstrojstvami autisticheskogo spektra // Pedagogika XXI veka: traditsii i innovatsii: Vseros. nauch. konf. s mezhdunar. uchastiem: sb. nauch. trudov / pod red. N.V. Fedinoj. Lipetsk, 2018. S. 82-85.

20. Yastrebova L.A. Formirovanie professional'no znachimykh kachestv budushchikh pedagogovdefektologov: avtoref. dis ... kand. ped. nauk. Armavir, 2008. 167 s.

\section{Библиографическое описание статьи / Reference to article}

Феофанов В.Н. Особенности личности специалиста, работающего с детьми с расстройствами аутистического спектра (часть 2) // Ученые записки Российского государственного социального университета. Т. 19. 2020. № 1 (154). C. 75-85. DOI: 10.17922/2071-53232020-19-1-75-85 (Библиографическое описание согласно российским стандартам).

Feofanov V.N. Osobennosti lichnosti specialista, rabotayushchego s det'mi s rasstrojstvami autisticheskogo spektra (chast' 2) // Uchenye zapiski Rossijskogo gosudarstvennogo social'nogo universiteta. T. 19. 2020. № 1 (154). S. 75-85. DOI: 10.17922/2071-5323-202019-1-75-85 (Reference in Roman script).

Feofanov, V.N. (2020) Personality Features of a Specialist Working with Children with Autism Spectrum Disorders (Part 2), Scientific Notes of Russian State Social University. Vol. 19. No. 1 (154). P. 75-85. D0I: 10.17922/2071-5323-2020-19-1-75-85 (International bibliographic description). 


\title{
Н.А. Цветкова,
}

д-р психол. наук, профессор кафедры социальной, общей и клинической психологии, Российский государственный социальный университет; ведущий научный сотрудник Научно-исследовательского института ФСИН России, Москва.

N.A. Tsvetkova,

doctor of psychological sciences, professor of the department of social, general and clinical psychology, Russian State Social University; leading researcher of the Scientific Research Institute of the Federal Service for the Execution of Punishments of Russia, Moscow.

E-mail: TsvetkovaNA@yandex.ru

\section{К.Е. Лагвилава,}

канд. психол. наук, доцент кафедры культурологии и музеологии,

Псковский государственный университет, Псков.

K.E. Lagvilava,

candidate of psychological sciences, associate professor of the department

of cultural studies and museology, Pskov State University, Pskov.

E-mail: helgaw@mail.ru

\section{Опыт повышения әффективности женских гругіI саморазвития}

\author{
Experience in Improving the Effectiveness \\ of Women's Self-Development Groups
}

$\begin{array}{ccc}\text { Дата поступления } & \text { Дата препринта } & \text { Дата публикации } \\ 23.12 .2019 & 28.02 .2020 & 30.03 .2020\end{array}$

Аннотация: в статье представлены результаты работы в трех женских группах саморазвития. I группа работала по программе Н.А. Цветковой (2012 г.). В целях повышения эффективности групповой работы программа была дополнена двумя темами: 1) «Я женщина. Какая я как женщина?»; 2) «Кто я в общении?». В целях психодиагностики и отслеживания результатов использовались: 1) методика изучения социально-психологической адаптации Р. Даймонда и К. Роджерса; 2) исследование самооценки путем ранжирования 20 качеств; 3) тест Э. Берна «Взрослый - Дитя - Родитель». Установлено, что дополненная программа более эффективна, так как достоверных позитивных изменений в показателях на начальном и завершающем этапах групповой работы гораздо больше в двух группах, работавших по дополненной программе, чем в группе, работавшей по ее базовому варианту. Это касается адаптации, самопринятия, принятия других, эмоционального комфорта, интернальности, структуры личности в зависимости от эго-состояний и личностного роста в целом.

Annotation: the article presents the results of work with women in three groups of self-development. Group I worked on the program N.A. Tsvetkova (2012). In order to improve the effectiveness of group work, the programme was supplemented by two themes: (1) "I am a woman. What woman am I?"; 2) "Who am I in communication?". For the purposes of psychodiagnostics and tracking the results, we used: 1) a method of studying the socio-psychological adaptation of R. Diamond and K. Rogers; 2) a study of self-esteem by ranking 20 qualities; 3) E. Bern's test "Adult - Child - Parent". It is established that the supplemented program is more effective, since there are much more significant positive changes in the indicators at the initial and final stages of group work in the two groups working on the supplemented program than in the group 
working on its basic version. This applies to adaptation, self-acceptance, acceptance of others, emotional comfort, internality, personality structure depending on the ego-States and personal growth in general.

Ключевые слова: женщины, саморазвитие, женские группы саморазвития, адаптация, самооценка, ролевые позиции в межличностном общении, эффективность работы женских групп саморазвития.

Key words: women, self-development, women's self-development groups, adaptation, self-esteem, role positions in interpersonal communication, the effectiveness of women's self-development groups.

Введение. Самоорганизация, саморазвитие, самореализация, самостоятельность и ответственность указываются в качестве главных принципов жизнедеятельности современного человека. Однако наблюдается немало взрослых людей, как женщин, так и мужчин, которые, став субъектом своей жизнедеятельности, не стали субъектами своего саморазвития. И, тем не менее, саморазвитие становится ценностью, в частности, современной россиянки [3; $4 ; 6 ; 9 ; 10 ; 13 ; 15 ; 17 ; 19 ; 20]$.

Фраза «Я исследую самого себя» приписывается Гераклиту. С нее началось социальное признание саморазвития. В свое время Гераклита поддержали Сократ, Марк Аврелий, Плотин, Августин - они сделали акцент на самопознании и самоопределении как духовном подвижничестве.

В эпоху Просвещения научная мысль (К.А. Гельвеций, И.Г. Гердер, Ж.-Ж. Руссо и др.) пришла к утверждению взглядов на самопознание как на условие самовоспитания и самообразования. А. Сен-Симон заявил: «Изучая самого себя, я изучаю одновременно всех людей». И если А. Гумбольдт усмотрел в самовоспитании продолжение естественного развития человека, то Г. Гегель раскрыл понятие саморазвития человека как «переработку» себя в процессе усвоения культуры.

К концу XIX века исследования саморазвития появились в психологии. Под саморазвитием понимался процесс деятельности личности, нацеленной на преобразование себя.

К концу 80-х годов XX века саморазвитие стало представляться в науке как путь к развитию индивидуальности. Например, об этом свидетельствуют работы Ю.М. Орлова [10 и др.], который рассматривал проблемы самовоспитания и самосовершенствования личности «в обыденной жизни». Причиной этому явилось накопление опыта педагогической практики и психологического консультирования.

В конце XX века К.А. Абульханова-Славская соотнесла саморазвитие с самосовершенствованием: «Самосовершенствование (саморазвитие) включает... процесс приобщения к культуре (своего общества, своей эпохи), постоянное повышение уровня своих знаний (в процессе непрерывного образования, пополнения имеющихся знаний новыми), наконец, процесс активной реализации себя в жизни (в труде, в творчестве)» [1, с. 261]. При этом автор говорит о двух основных стратегиях личности: 1) учет своих наличных ресурсов; 2) совершенствование своих психических возможностей.

В XXI веке М.А. Щукина с позиции субъектного подхода разработала психологию саморазвития личности, обобщив многочисленные исследования по данной проблеме. Саморазвитие, с ее точки зрения, - «это качественное, необратимое, направленное изменение личности, осуществляемое под управлением самой личности. ....Значение саморазвития на жизненном пути личности раскрывается через следующие его функции: снятие жизненной неопределенности, творение индивидуальности, создание неотторжимого Я-продукта, наполнение жизни смыслом, достижение личностной зрелости» [18]. Стоит согласиться с этим автором также и в том, что саморазвитие является частным случаем жизнетворчества.

Неуклонный рост научного интереса к проблеме саморазвития личности подтверждается тем фактом, что в электронной библиотеке «E-library» содержится свыше 6000 публикаций, касающихся ее тем или иным образом.

Официально признанная в России в 1991 году социальная работа стимулировала развитие групповых форм социально-психологической помощи женщинам, поскольку именно женщины, оказавшись в трудной жизненной ситуации, гораздо чаще ищут ее, чем мужчины 
$[2 ; 5 ; 12 ; 14 ; 17 ; 20]$. Идея организация групп саморазвития для женщин основана на понимании того, что человеку нужно такое социальное окружение, которое поддерживало бы и стимулировало его на пути к самоидентификации, раскрытию своей подлинной сущности и дифференцированности. Именно в процессе общения с такими людьми женщина ощущает прилив сил, в ней пробуждается мысль и активное действие, она начинает осознавать свою неадекватность и вносить соответствующие коррективы в свое поведение. 0бщение с себе подобными есть источник жизненной энергии, необходимое условие развития Силы личности. Однако основную ценность представляет не интенсивное общение само по себе, а его глубина и доверительность, которые могут быть исповедальными, что способствует освобождению женщин от тягостных переживаний и усвоению нового опыта. Группа саморазвития для них является местом, где они имеют возможность понять, какие они как женщины и определить, какими они хотят и могут стать, используя свои ресурсы. Одновременно это - и условие преодоления социально-психологической дезадаптации, достижения эмоционального комфорта, повышения социальной адаптивности $[8 ; 10 ; 12 ; 17]$.

Такие группы могут создаваться в рамках феминистской социальной работы, однако в данном случае речь идет о женских группах саморазвития, в процессе работы которых решается задача развития у женщин навыков самопознания, жизненного планирования и ауто-психо-социальной коррекции, но цель борьбы за гендерное равенство не ставится [17]. В то же время важны оценка эффективности групповой работы и последующее совершенствование программы группового общения и взаимодействия.

Выборку нашего исследования составили 39 женщин, посещавших группы саморазвития (I группа - 12 женщин в возрасте от 29 до 39 лет), (II группа - 15 женщин в возрасте от 52 до 55 лет), (III группа - 12 женщин в возрасте от 32 до 38 лет). Все группы работали по программе Н.А. Цветковой [16, с. 230-278], включающей в себя 12 групповых встреч. Их тематика охватывает шесть аспектов: 1) «Я и мое одиночество»; 2) «Мой таймменеджмент»; 3) «Мое право человека женщины»; 4) «Я и моя социальная сеть»; 5) «Моя Сила Личности»; 6) «Узелки на память обо мне» [17, с. 260].

Однако после завершения работы I группы и анализа полученных результатов возникло предположение, что задача выхода женщин на уровень саморазвития в условиях группового взаимодействия может решаться более эффективно, если на начальном этапе работы группы будет отведено время для диагностики и коррекции признаков социально-психологической дезадаптации, самооценки и ролевых позиций в межличностном общении.

Методы и методики исследования. В целях диагностики признаков социально-психологической дезадаптации и отслеживания результатов коррекционно-развивающей работы нами использовались следующие методики: 1) методика изучения особенностей социально-психологической адаптации Р. Даймонда и К. Роджерса (СПА) [16, с. 197-198]; 2) методика исследования самооценки с помощью процедуры ранжирования 20 качеств личности; 3) методика определения ролевых позиций в межличностном общении и структуры личности в зависимости от эго-состояний «Взрослый - Дитя - Родитель» (тест Э. Берна) [16, с. 13-14].

Математико-статистическая обработка данных осуществлялась с помощью MS Office Excel, IBM SPSS Statistics 23.

\section{Результаты исследования.}

I. Результаты диагностики признаков социально-психологической дезадаптации.

1.1. Результаты диагностики особенностей социально-психологической адаптации по тесту «СПА» Р. Даймонда и К. Роджерса (представлены в табл. 1).

Данные таблицы 1 свидетельствуют о том, что показатели параметров «адаптация» и «эмоциональный комфорт» во всех трех женских группах ниже 50\% (являются признаками социально-психологической дезадаптации), хотя другие параметры находятся в пределах нормы («лживость» и «эскапизм») и средних значений («самопринятие», «принятие других», «интернальность», «доминирование»). 
Таблица 1

Уровни выраженности восьми параметров социально-психологической адаптации у женщин, изъявивших желание посещать группу саморазвития (средние значения)

\begin{tabular}{|l|c|c|c|}
\hline \multirow{2}{*}{\multicolumn{1}{c|}{ Пораметр }} & \multicolumn{3}{c|}{ Группы } \\
\cline { 2 - 4 } & $\begin{array}{c}\text { I } \\
\text { (29-39 лет) }\end{array}$ & $\begin{array}{c}\text { II } \\
\text { (52-55 лет) }\end{array}$ & $\begin{array}{c}\text { III } \\
\text { (32-38 лет) }\end{array}$ \\
\hline 1. Лживость (в баллах) & 31 & 29 & 31 \\
\hline 2. Адаптация (в\%) & 47 & 43 & 47 \\
\hline 3. Самопринятие (в \%) & 67 & 59 & 66 \\
\hline 4. Принятие других (в\%) & 62 & 59 & 63 \\
\hline 5. Эмоциональный комфорт (в\%) & 47 & 42 & 48 \\
\hline 6. Интернальность (в \%) & 60 & 56 & 55 \\
\hline 7. Доминирование (в \%) & 61 & 55 & 60 \\
\hline 8. Эскапизм (в баллах) & 14 & 13 & 15 \\
\hline
\end{tabular}

1.2. Результаты исследования самооценки (представлены в табл. 2).

Таблица 2

Особенности самооценки женщин - участниц трех групп саморазвития

\begin{tabular}{|l|c|c|c|}
\hline \multirow{2}{*}{$\begin{array}{c}\text { Замеряемый признак } \\
\text { социально-психологической (дез)адаптации }\end{array}$} & \multicolumn{3}{|c|}{ Группы } \\
\cline { 2 - 4 } & $\begin{array}{c}\text { I } \\
\text { 1. Самооценка }\end{array}$ & $\begin{array}{c}\text { II } \\
\text { (29-59 лет) }\end{array}$ & $\begin{array}{c}\text { III } \\
\text { (32-38 лет) }\end{array}$ \\
\hline
\end{tabular}

Таблица 2 показывает, что самооценка женщин всех трех групп хотя и относится к области средних значений, но тяготеет к заниженной (диапазон адекватной (среднего уровня) самооценки составляет 0,41-0,71).

При более детальном анализе данных по этому параметру обнаружено, что внутри всей выборки самооценки женщин заметно различаются, о чем свидетельствуют данные, представленные в таблице 3.

Таблица 3

Распределение женщин трех групп по уровням самооценки

\begin{tabular}{|l|c|c|c|}
\hline \multirow{2}{*}{\multicolumn{2}{|c|}{ Группа }} & \multicolumn{3}{|c|}{ Уровни самооценки (чел./\%) } \\
\cline { 2 - 4 } & высокий & средний & низкий \\
\hline I (52-55 лет) & $4(26,7 \%)$ & $8(53,3 \%)$ & $3(20,0 \%)$ \\
\hline II (32-38 лет) & $4(33,3 \%)$ & $6(50,0 \%)$ & $2(16,7 \%)$ \\
\hline III (29-39 лет) & $3(25,0 \%)$ & $4(33,3 \%)$ & $5(41,7 \%)$ \\
\hline По выборке в целом & $11(28,2 \%)$ & $18(46,2 \%)$ & $10(25,6 \%)$ \\
\hline
\end{tabular}

Таблица 3 показывает, что более половины женщин, пожелавших посещать группу саморазвития, имели неадекватную самооценку.

1.3. Результаты исследования ролевых позиций в межличностном общении (представлены в табл. 4).

Таблица 4 отражает тенденцию по выборке в целом - доминирование ролевой позиции «Взрослый» в структуре личности обследованных женщин. По Э. Берну, становление зрелой личности связано с ярко выраженным и полноценно функционирующим эго-состоянием «Взрослый», после которого следует «Дитя», а потом - «Родитель». Человек, находящийся 
на данной позиции, отличается ответственностью, в меру импульсивен, избегает давать указания и поучать.

Таблица 4

\begin{tabular}{||l|c|c|c|}
\hline \multirow{2}{*}{$\begin{array}{c}\text { Ролевая позиция в межличностном } \\
\text { общении (максимальное значение } \\
\text { по каждому параметру - 70 баллов) }\end{array}$} & \multicolumn{3}{|c|}{ Группы } \\
\cline { 2 - 4 } & $\mathbf{( 2 9 - 3 9}$ лет) & $\begin{array}{c}\text { II } \\
\text { (52-55 лет) }\end{array}$ & $\begin{array}{c}\text { III } \\
\text { (32-38 лет) }\end{array}$ \\
\hline «Взрослый» & 52 & 47 & 54 \\
\hline «Дитя» & 31 & 33 & 32 \\
\hline «Родитель» & 43 & 35 & 46 \\
\hline
\end{tabular}

Нарушения в структуре личности определяются преобладанием одного из двух других эго-состояний - «Родителя» или «Дитя», - что приводит к неадекватному поведению, эмоциональному дискомфорту и социально-психологической дезадаптации.

Результаты более глубокого анализа особенностей структуры личности обследованных женщин в зависимости от их ролевых позиций в межличностном общении (эго-состояний «Взрослый» - «Дитя» - «Родитель») представлены в таблице 5.

Таблица 5

\begin{tabular}{|c|c|c|c|}
\hline \multirow{2}{*}{$\begin{array}{c}\text { Вариант структуры личности } \\
\text { в зависимости от ролевой позиции } \\
\text { в межличностном общении }\end{array}$} & \multicolumn{3}{|c|}{ Группы } \\
\hline & $\begin{array}{c}\text { I } \\
\text { (29-39 лет), } \\
\text { чел./\% } \\
\end{array}$ & $\begin{array}{c}\text { II } \\
\text { (52-55 лет), } \\
\text { чел./\% }\end{array}$ & $\begin{array}{c}\text { III } \\
\text { (32-38 лет), } \\
\text { чел./\% }\end{array}$ \\
\hline Нормативный вариант «ВДР» & $0(0 \%)$ & $0(0 \%)$ & $0(0 \%)$ \\
\hline Нарушение по типу «ВРД» & $10(83,3 \%)$ & $11(73,3 \%)$ & $10(83,3 \%)$ \\
\hline Нарушение по типу «ДВР» & $0(0 \%)$ & $4(26,7 \%)$ & $0(0 \%)$ \\
\hline Нарушение по типу «РВД» & $2(16,7 \%)$ & $0(0 \%)$ & $2(16,7 \%)$ \\
\hline
\end{tabular}

Примечание: В - Взрослый, Д - Дитя, Р - Родитель.

Судя по данным таблицы 5, в структуре личности обследованных женщин самым распространенным нарушением оказалось нарушение по типу «Взрослый» - «Родитель» - Дитя». Эго-состояние «Родитель» выступает носителем норм и социальных предписаний, усвоенных человеком в течение жизни. У женщин оно обнаруживается себя в таких особенностях межличностного взаимодействия, как контроль, запреты, высокие требования, категоричность и т.п. Для женщин с нарушением структуры личности по этому типу характерны также догматичность и жесткость.

Эго-состояние «Дитя» выступает носителем биологических потребностей и основных ощущений человека, содержит в себе аффективные комплексы, связанные с ранними детскими впечатлениями и переживаниями, позитивные (спонтанность, творчество, интуиция) и негативные (отсутствие произвольной регуляции поведения, неконтролируемая активность) качества. Женщины с доминирующим эго-состоянием «Дитя» могут состояться в научной работе, но не всегда могут управлять своими чувствами. Таких женщин в общей выборке оказалось около $10 \%$.

Доминирующее эго-состояние «Родитель» (вариант РВД) (также около 10\%) позволяет предположить, что для этой части женщин характерна категоричность в суждениях и поступках, чрезмерная самоуверенность в общении; они часто говорят, не сомневаясь в достоверности сказанного и не заботясь о последствиях своих слов и действий.

Поскольку в структуре личности большинства обследованных женщин (около 80\%) эгосостояние «Родитель» доминирует над эго-состоянием «Дитя», мы предположили, что их по- 
требность в саморазвитии оказалась ограниченной. Соответственно, психологическая помощь должна быть направлена на установление баланса трех названных компонентов структуры личности, а именно на усиление эго-состояния «Взрослого» как ведущего компонента и «Дитя» как следующего за ним эго-состояния.

0бобщенные результаты психодиагностики 39 женщин показали наличие у женщин трех групп таких признаков социально-психологической дезадаптации, как низкий уровень адаптации и эмоционального комфорта, неадекватная самооценка, нарушения в структуре личности, определяемые по неадекватности проявления ролевых позиций «Родитель» и «Дитя» в межличностном общении. Этот результат убедил нас в том, что тематику занятий в женских группах саморазвития целесообразно дополнять двумя темами: 1) «Я женщина. Какая я как женщина?» (работа с самооценкой по критериям: «тело», «общение», «деятельность», «уровень развития личности»); 2) «Кто я в общении?»: коррекция структуры личности в зависимости от эго-состояний «Взрослый» - «Дитя» - Родитель» методом ролевой игры с последующим анализом поведения и речи участниц.

II. Анализ результатов работы, полученных в трех женских группах саморазвития (представлен в табл. 6).

Таблица 6

Результаты сравнительного анализа данных в трех женских группах саморазвития (средние значения)

\begin{tabular}{|c|c|c|c|c|c|}
\hline \multirow{3}{*}{ Замеряемый параметр } & \multicolumn{4}{|c|}{ Группы } \\
\cline { 2 - 6 } & \multicolumn{2}{|c|}{ I } & \multicolumn{2}{|c|}{ II } & \multicolumn{2}{|c|}{ III } \\
& $(29-39$ лет $)$ & $(52-55$ лет) & \multicolumn{2}{c|}{ (32-38 лет) } \\
\cline { 2 - 6 } & начало & завершение & начало завершение & начало & завершение \\
\hline
\end{tabular}

1. Социально-психологическая адаптация

\begin{tabular}{|l|c|c|c|c|c|c|}
\hline Лживость & 31 & 31 & 29 & 28 & 31 & 31 \\
\hline Адаптация & 47 & 58 & 43 & 64 & 47 & 62 \\
\hline Самопринятие & 67 & 72 & 59 & 70 & 66 & 73 \\
\hline Принятие других & 62 & 71 & 59 & 71 & 63 & 74 \\
\hline $\begin{array}{l}\text { Эмоциональный } \\
\text { комфорт }\end{array}$ & 47 & 59 & 42 & 59 & 48 & 63 \\
\hline Интернальность & 60 & 64 & 56 & 66 & 55 & 63 \\
\hline Доминирование & 61 & 61 & 55 & 58 & 60 & 60 \\
\hline Эскапизм & 14 & 15 & 13 & 15 & 15 & 14 \\
\hline 2. Самооценка & 0,44 & 0,53 & 0,58 & 0,64 & 0,55 & 0,64 \\
\hline \multicolumn{7}{|l|}{3. Ролевая позиция } \\
\hline «Взрослый» & 52 & 54 & 47 & 58 & 54 & 56 \\
\hline «Дитя» & 31 & 41 & 33 & 39 & 32 & 42 \\
\hline «Родитель» & 43 & 38 & 35 & 30 & 46 & 39 \\
\hline
\end{tabular}

Для установления достоверности различий в отслеживаемых параметрах групповой работы с женщинами мы назвали I группу (женщины 29-39 лет) «контрольной группой» (они работали по базовой программе), две другие объединили в одну - «экспериментальную группу» (в этих группах работа велась по усовершенствованной программе) и полученный результат представили в таблице 7.

Таблица 7 явно демонстрирует межгрупповые различия в результатах по параметрам: «адаптация», «эмоциональный комфорт», «интернальность», «эго-состояние "Взрослый"».

Сравнительный анализ полученных данных по критерию Манна-Уитни показал, что достоверных различий (при $p \leq 0,01)$ в экспериментальной группе больше, чем в контрольной. Так, в экспериментальной группе при оценке сдвига до и после проведения работы 
Результаты, полученные в контрольной и экспериментальной женских группах саморазвития

\begin{tabular}{|l|c|c|c|c|}
\hline \multirow{2}{*}{ Замеряемый параметр } & \multicolumn{2}{c|}{$\begin{array}{c}\text { Контрольная группа } \\
\text { (женщины 29-39 лет) }\end{array}$} & $\begin{array}{c}\text { Экспериментальная группа } \\
\text { (женщины 32-55 лет) }\end{array}$ \\
\cline { 2 - 5 } & начало & завершение & начало & завершение \\
\hline 1. Социально-психологическая адаптация & 31 & 31 & 30 & 30 \\
\hline Лживость & 47 & 58 & 46 & 63 \\
\hline Адаптация & 67 & 72 & 63 & 72 \\
\hline Самопринятие & 62 & 71 & 61 & 73 \\
\hline Принятие других & 47 & 59 & 45 & 61 \\
\hline Эмоциональный комфорт & 60 & 64 & 56 & 65 \\
\hline Интернальность & 61 & 61 & 58 & 59 \\
\hline Доминирование & 14 & 15 & 14 & 15 \\
\hline Эскапизм & 0,44 & 0,53 & 0,57 & 0,64 \\
\hline 2. Самооценка & & & & \\
\hline 3. Ролевые позиции & 52 & 54 & 51 & \\
\hline «Взрослый» & 31 & 41 & 33 & \\
\hline «Дитя» & 43 & 38 & 42 & 42 \\
\hline «Родитель» & \multicolumn{5}{|l|}{35} \\
\hline
\end{tabular}

по усовершенствованной программе достоверно различаются показатели: адаптации $(U=0$ при $p=0,000)$, самопринятия $(U=161,0$ при $p=0,000)$, принятия других $(U=49$ при $p=0,000)$, эмоционального комфорта $(U=0$ при $p=0,000)$, интернальности $(U=144,0$ при $\mathrm{p}=0,000)$, а также выраженности всех трех эго-состояний в структуре личности - «Взрослый» $(U=215,0$ при $p=0,009)$, «Дитя» $(U=166,0$ при $p=0,001)$ и «Родитель» $(U=219,0$ при $\mathrm{p}=0,012)$. Иными словами, наблюдается личностный рост.

В то же время в контрольной группе при оценке сдвига до и после работы по базовой программе выявлены достоверные различия в показателях: адаптации $(U=0$ при $p=0,000)$, эмоционального комфорта ( $U=0$ при $p=0,000)$, выраженности эго-состояний «Дитя» $(U=25,5$ при $p=0,004)$ и «Родитель» $(U=30,0$ при $p=0,014)$ в структуре личности, что в большей степени свидетельствует об успехе решения задач психокоррекции, чем о личностном росте женщин.

Таким образом, результаты экспериментальной работы показали, что усовершенствованная программа саморазвития для женщин в условиях групповой работы более эффективна.

0бсуждение. Обобщая полученные данные по всем трем методикам, отметим, что женщины, изъявляющие желание посещать группу саморазвития, могут иметь (и, судя по нашим данным, около половины из них имеют) социально-психологические барьеры, сдерживающие процесс их личностного роста, - это, как минимум, два признака социально-психологической дезадаптации (нарушение адаптации и эмоциональный дискомфорт); неадекватная (чаще заниженная) самооценка; неадекватные ролевые позиции в межличностном общении (хотя в целом по женской выборке отмечено доминирование ролевой позиции «Взрослый» в структуре личности, что является нормативным вариантом развития, однако обнаружены другие нарушения: 1) женщины с доминирующим эго-состоянием «Дитя» (их оказалось около 10\%); 2) женщины с доминирующим эго-состоянием «Родитель» (также около 10\%); 3) в структуре личности эго-состояние «Родитель» доминирует над эго-состоянием «Дитя» (80\% обследованных женщин). Любая из этих деформаций структуры личности женщины является фактором, сдерживающим ее личностный рост и реализацию потребности в саморазвитии, обусловливает социально-психологическую дезадаптацию). 
Полученные экспериментальным путем данные говорят о том, что расширение тематики занятий в двух женских группах саморазвития оказалось оправданным, поскольку результаты сравнительного анализа данных экспериментальной и контрольной групп показали более высокий уровень достижений, если женщины работали по дополненной программе.

Эти результаты подтверждают правомерность предположения о том, что коррекция самооценки и ролевых позиций в межличностном общении на начальном этапе работы женской группы саморазвития ведет к ослаблению у женщин симптомов социально-психологической дезадаптации и в конечном итоге к повышению эффективности решения задач групповой работы в женских группах саморазвития.

В заключение отметим тот факт, что при всей ценности саморазвития личности оно имеет и свои опасности, которые целесообразно учитывать в работе с женскими группами саморазвития [7].

\section{Список литературы}

1. Абульханова-Славская К.А. Стратегия жизни. М.: Мысль, 1991. 299 с.

2. Анцыферова Л.И. Личность в трудных жизненных условиях: переосмысление, преобразование ситуаций и психологическая защита // Психологический журнал. Т. 15. 1994. № 1. С. 3-18.

3. Гребенюк Е.Н., Сулейманова Е.В. Особенности оказания социально-психологической помощи женщинам, оказавшимся в сложной жизненной ситуации // Молодой ученый. 2017. № 4. C. 326-329. URL: https: //moluch.ru/archive/138/38650/ (дата обращения: 23.05.2019).

4. Исполатова С. Самосознание женщины как фактор обновления общественного строя // Женщина и земля. 1992. № 3. С. 45-47.

5. Красавцева Л.Е. Адаптация как условие вхождения личности в социум // Среднее профессиональное образование. 2010. № 6. С. 54-55.

6. Литвяк Л.А. Оказание психологической помощи женщинам, оказавшимся в трудной жизненной ситуации // Интегративные тенденции в медицине и образовании. 2015. № 1 . C. 56-62.

7. Маралов В.Г. Ценность и опасности саморазвития личности // Международный научно-исследовательский журнал. 2015. № 6 (37). Ч. 4. С. 51-53. URL: https://researchjournal.org/psycology/cennost-i-opasnosti-samorazvitiya-lichnosti/ (дата обращения: 23.05.2019).

8. Немиринский О.В. Личностный рост в терапевтической группе. М.: Смысл, 1999. 112 с.

9. Овсяник 0.А. Адаптация женщин второго периода взрослости // Социально-экономические явления и процессы. 2011. № 11. С. 341-345.

10. Овсяник 0.А. Особенности профилактики социально-психологической дезадаптации женщин старше 45 лет // Психология человека в условиях здоровья и болезни: матер. V Междунар. науч.-практ. конф. (г. Тамбов, 2015 г.). Тамбов: Бизнес - Наука - Общество, 2015. C. 138-141.

11. Орлов Ю.М., Творогова Н.Д., Безносюк Е.Н. Самовоспитание и самосовершенствование: учеб. пособие / под ред. И.А. Сыченикова. М.: ММИ, 1988. 39 с.

12. Плешакова 0.Л. Групповое психологическое консультирование при созависимости // Современные научные исследования и разработки. 2018. № 10 (27). С. 730-732.

13. Сац Е.А. Особенности самосознания женщин, недовольных собственной внешностью: дис. ... канд. психол. наук. М., 2015. 173 с.

14. Сесенова Н.Д, Кузьменко Ю.А., Костюк Г.П. Психообразование: проблемы и направления исследований // Обозрение психиатрии и медицинской психологии. 2016. № 4. С. 3-11.

15. Томилов Е.В., Иванова Е.С. Стратегии социально-психологической адаптации мужчин и женщин в молодом возрасте // Личность в современном мире: матер. науч.-практ. конф. (г. Екатеринбург, 25 января 2016 г.): сб. науч. ст. Екатеринбург: Урал. гос. пед. ун-т, 2016. С. 212-218.

16. Фетискин Н.П., Козлов В.В., Мануйлов Г.М. Социально-психологическая диагностика личности и малых групп. М.: ИП, 2002. 490 с.

17. Цветкова Н.А. Социально-психологическое обслуживание женщин: учеб. пособие. Псков: Логос, 2012. 400 c. 
18. Щукина М.А. Психология саморазвития личности: субъектный подход: дис. ... д-ра психол. наук. СПб., 2015. 355 с.

19. Mityaeva A.M., Fomina S.N., Tsvetkova N.A., Rybakova A.I., Gedulyanova N.S., Khovanskaya E.A. Psychological conseling strategies for women regarding their level of fulfillment of need for personal development // Turkish online journal of design art and communication. Vol. 7. 2017. No. S-APRLSPCL. P. 3263-3283. URL: https://elibrary.ru/contents.asp?id=34520440.

20. Tsvetkova N.A., Rybakova A.I., Fomina S.N., Petrova E.A., Shcheglova A.S. Personality traits of women of mature age with and low levels of need in self-development actualization // Man In India. 2016. No. 96 (7). P. 2025-2051. URL: http: //serialsjournals.com/ serialjournalmanager/pdf/1469596789.pdf.

\section{References}

1. Abul'khanova-Slavskaya K.A. Strategiya zhizni. M.: Mysl', 1991. 299 s.

2. Ancyferova L.I. Lichnost' $v$ trudnykh zhiznennykh usloviyakh: pereosmyslenie, preobrazovanie situacij i psikhologicheskaya zashchita // Psikhologicheskij zhurnal. T. 15. 1994. № 1. S. 3-18.

3. Grebenyuk E.N., Sulejmanova E.V. Osobennosti okazaniya social'no-psikhologicheskoj pomoshchi zhenshchinam, okazavshimsya v slozhnoj zhiznennoj situacii // Molodoj uchenyj. 2017. № 4. S. 326-329. URL: https: //moluch.ru/archive/138/38650/ (data obrashcheniya: 23.05.2019).

4. Ispolatova S. Samosoznanie zhenshchiny kak faktor obnovleniya obshchestvennogo stroya // Zhenshchina i zemlya. 1992. № 3. S. 45-47.

5. Krasavceva L.E. Adaptaciya kak uslovie vkhozhdeniya lichnosti v socium // Srednee professional'noe obrazovanie. 2010. № 6. S. 54-55.

6. Litvyak L.A. Okazanie psikhologicheskoj pomoshchi zhenshchinam, okazavshimsya $v$ trudnoj zhiznennoj situacii // Integrativnye tendencii v medicine i obrazovanii. 2015. № 1. S. 56-62.

7. Maralov V.G. Cennost' i opasnosti samorazvitiya lichnosti // Mezhdunarodnyj nauchnoissledovatel'skij zhurnal. 2015. № 6 (37). Ch. 4. S. 51-53. URL: https://research-journal.org/ psycology/cennost-i-opasnosti-samorazvitiya-lichnosti/ (data obrashcheniya: 23.05.2019).

8. Nemirinskij 0.V. Lichnostnyj rost v terapevticheskoj gruppe. M.: Smysl, 1999. $112 \mathrm{s.}$

9. Ovsyanik 0.A. Adaptaciya zhenshchin vtorogo perioda vzroslosti // Social'no-ekonomicheskie yavleniya i processy. 2011. № 11. S. 341-345.

10. Ovsyanik 0.A. Osobennosti profilaktiki social'no-psikhologicheskoj dezadaptacii zhenshchin starshe 45 let // Psikhologiya cheloveka v usloviyakh zdorov'ya i bolezni: mater. V Mezhdunar. nauch.-prakt. konf. (g. Tambov, 2015 g.). Tambov: Biznes - Nauka - Obshchestvo, 2015. S. $138-141$.

11. Orlov Yu.M., Tvorogova N.D., Beznosyuk E.N. Samovospitanie i samosovershenstvovanie: ucheb. posobie / pod red. I.A. Sychenikova. M.: MMI, 1988. $39 \mathrm{~s}$.

12. Pleshakova 0.L. Gruppovoe psikhologicheskoe konsul'tirovanie pri sozavisimosti // Sovremennye nauchnye issledovaniya i razrabotki. 2018. № 10 (27). S. 730-732.

13. Sac E.A. Osobennosti samosoznaniya zhenshchin, nedovol'nykh sobstvennoj vneshnost'yu: dis. ... kand. psikhol. nauk. M., 2015. 173 s.

14. Sesenova N.D, Kuz'menko Yu.A., Kostyuk G.P. Psikhoobrazovanie: problemy i napravleniya issledovanij // Obozrenie psikhiatrii i medicinskoj psikhologii. 2016. № 4. S. 3-11.

15. Tomilov E.V., Ivanova E.S. Strategii social'no-psikhologicheskoj adaptacii muzhchin i zhenshchin $v$ molodom vozraste // Lichnost' v sovremennom mire: mater. nauch.-prakt. konf. (g. Ekaterinburg, 25 yanvarya 2016 g.): sb. nauch. st. Ekaterinburg: Ural. gos. ped. unt, 2016. S. 212-218.

16. Fetiskin N.P., Kozlov V.V., Manujlov G.M. Social'no-psikhologicheskaya diagnostika lichnosti i malykh grupp. M.: IP, 2002. $490 \mathrm{~s}$.

17. Cvetkova N.A. Social'no-psikhologicheskoe obsluzhivanie zhenshchin: ucheb. posobie. Pskov: Logos, 2012. $400 \mathrm{~s}$.

18. Shchukina M.A. Psikhologiya samorazvitiya lichnosti: sub"ektnyj podkhod: dis. ... d-ra psikhol. nauk. SPb., 2015. 355 s.

19. Mityaeva A.M., Fomina S.N., Tsvetkova N.A., Rybakova A.I., Gedulyanova N.S., Khovanskaya E.A. Psychological conseling strategies for women regarding their level of fulfillment of need for personal development // Turkish online journal of design art and communication. Vol. 7. 2017. No. S-APRLSPCL. P. 3263-3283. URL: https://elibrary.ru/contents.asp?id=34520440. 
20. Tsvetkova N.A., Rybakova A.I., Fomina S.N., Petrova E.A., Shcheglova A.S. Personality traits of women of mature age with and low levels of need in self-development actualization // Man In India. 2016. No. 96 (7). P. 2025-2051. URL: http: //serialsjournals.com/ serialjournalmanager/pdf/1469596789.pdf.

\section{Библиографическое описание статьи / Reference to article}

Цветкова Н.А., Лагвилава К.Е. Опыт повышения эффективности женских групп саморазвития // Ученые записки Российского государственного социального университета. Т. 19. 2020. № 1 (154). C. 86-95. DOI: 10.17922/2071-5323-2020-19-1-86-95 (Библиографическое описание согласно российским стандартам).

Cvetkova N.A., Lagvilava K.E. Opyt povysheniya effektivnosti zhenskikh grupp samorazvitiya // Uchenye zapiski Rossijskogo gosudarstvennogo social'nogo universiteta. T. 19. 2020. № 1 (154). S. 86-95. DOI: 10.17922/2071-5323-2020-19-1-86-95 (Reference in Roman script).

Tsvetkova, N.A. \& Lagvilava, K.E. (2020) Experience in Improving the Effectiveness of Women's Self-Development Groups, Scientific Notes of Russian State Social University. Vol. 19. No. 1 (154). P. 86-95. DOI: 10.17922/2071-5323-2020-19-1-86-95 (International bibliographic description). 


\title{
Е.А. Петрова,
}

д-р психол. наук, профессор, декан факультета психологии,

заведующая кафедрой социальной, общей и клинической психологии,

Российский государственный социальный университет, Москва.

E.A. Petrova,

doctor of psychological sciences, professor, dean of the faculty of psychology,

head of the department of social, general and clinical psychology,

Russian State Social University, Moscow.

E-mail:petrova-sorina@yandex.ru

\section{К.С. Хожеева,}

магистрантка, Российский государственный социальный университет, Москва.

K.S. Khozheeva,

master student, Russian State Social University, Moscow.

E-mail: propunker@mail.ru

\section{Социально-психологические особенности лиц с нарушениями пищевого поведения}

\author{
Socio-Psychological Characteristics \\ of People with Eating Disorders
}

\author{
Дата поступления \\ Дата препринта \\ 26.12.2019 \\ 28.02.2020 \\ Дата публикации \\ 30.03.2020
}

Аннотация: в статье представлены результаты исследования социально-психологических особенностей лии с нарушением и без нарушений пищевого поведения в целях дальнейшей практической работы по устранению пищевых девиаций. Для проведения исследования использовались такие психодиагностические методики, как «Калифорнийский психологический опросник» (CPI), «Опросник структуры темперамента» (ОСТ), «Когнитивно-поведенческие паттерны при нарушениях пищевого поведения», а также непараметрические методы статистики: U-критерий Манна-Уитни и корреляционный анализ по Спирмену. Авторы выдвинули предположение, что лица с нарушениями пищевого поведения отличаются от лиц без нарушений пищевого поведения по таким шкалам CPI, как: доминирование, общительность, социальное присутствие, самопринятие, независимость, ответственность, самоконтроль, хорошее впечатление; обычность, чувство благополучия, толерантность, психологический склад ума, женственность/мужественность, - а также по таким шкалам ОСТ, как социальная эргичность, социальная эмоциональность. Полученные данные могут применяться в частной и групповой психотерапевтической практике.

Annotation: the article presents the results of a study of socio-psychological characteristics of people with and without eating disorders in order to further practical work to eliminate food deviations. The study used such psychodiagnostic methods as the "California psychological questionnaire" (CPI), the "Temperament structure Questionnaire" (OST), and "Cognitive behavioral patterns in eating disorders", as well as nonparametric statistical methods such as the Mann-Whitney U-test and Spearman correlation analysis. The authors suggested that people with eating disorders differ from people without eating disorders in such CPI scales as: dominance, sociability, social presence, self - acceptance, independence, responsibility, selfcontrol, good impression; ordinariness, sense of well-being, tolerance, psychological mindset, femininity/ masculinity-as well as in such OST scales as social ergic, social emotionality. The obtained data can be used in private and group psychotherapy practice. 
Ключевые слова: пищевое поведение, нарушения пищевого поведения, анорексия, булимия, паттерны пищевого поведения, социально-психологические характеристики личности, терапия пищевого поведения, социальная психология.

Key words: eating behavior, eating disorders, anorexia, bulimia, eating patterns, socio-psychological characteristics of a person, eating behavior therapy, social psychology.

Введение. В связи с многообразием форм аддиктивного или неадекватного пищевого поведения в современном обществе возрастает необходимость в установлении закономерностей, влияющих на те или иные паттерны пищевого поведения. В частности, актуальным является вопрос социально-психологических детерминант образования пищевых девиаций.

Так, проблемой психологических детерминант в вопросе пищевых нарушений занимались Е.Т. Соколова [22], И.Г. Малкина-Пых [7; 8], 0.А. Скугаревский [20; 21], 0.А. Сивуха [19], А.В. Вахмистров [1], Т.Г. Вознесенская [2; 3], Т.Л. Шабанова [25], В.Д. Менделевич [10; 11], Н.0. Николаева [12; 13], Ю.Л. Савчикова [17], Ю.Г. Фролова [24], У.В. Макарова [6], Л.Г. Пономарева [14], В.В. Марилов [9] и многие другие. Современная психология рассматривает проблему нарушений пищевого поведения как комплекс факторов различного генеза. Сюда относятся генетические, физиологические, социальные, психологические и культурные факторы. Каждый из этих подходов сыграл существенную роль в формировании научных представлений о пищевом поведении. Тем не менее полученная картина пока не может считаться исчерпывающей в отношении социально-психологических аспектов проблемы.

Несмотря на проделанный труд в этом направлении, противоречивы данные относительно тех особенностей социально-психологической сферы, которые могли бы иметь массовый характер и накладывать отпечаток на целые группы людей с нарушениями пищевого поведения (далее - НПП), имеющих проблемы с весом, пищей или отношением к собственному телу. Наиболее часто в литературе выделяют такие социально-психологические черты, присущие людям с НПП, как высокая подверженность стрессу и использование неадаптивных методов разрешения проблем и конфликтов, зависимость от общественного мнения, трудности в построении близких взаимоотношений. Мы считаем, что проведение многофакторного эмпирического исследования по данной проблематике дополнит теоретическое представление о НПП в психологической науке, а также позволит повысить эффективность психокоррекционной работы психолога в практической деятельности.

Итак, предметом нашего исследования стала взаимосвязь социально-психологических характеристик и пищевого поведения личности. Мы предположили, что лица с нарушениями пищевого поведения отличаются от лиц без нарушений определенными социально-психологическими характеристиками. Достоверность результатов проведенного исследования и сделанных на их основе выводов достигалась с помощью использования методов математического качественного и количественного анализа данных, корреляционного анализа.

Методика. Эмпирическое исследование социально-психологических особенностей лиц с нарушениями пищевого поведения проводилось с февраля 2018 по август 2019 года. В целях проведения психологического исследования была организована социальная выборка, отвечающая нашему исследовательскому интересу. В качестве испытуемых мы пригласили 60 человек славянского этноса, преимущественно жителей мегаполиса, имеющих постоянное место работы или обучающихся в вузе, среди которых были девушки и женщины от 18 до 35 лет. В качестве основного инструмента формирования социальной выборки исследования мы использовали методику «Когнитивно-поведенческие паттерны при нарушениях пищевого поведения» А.0. Сагалаковой и М.Л. Киселевой (2014 г.) (далее - КППП). Результаты, полученные по этой методике, позволили нам разделить респондентов на контрольную и экспериментальную группы. Таким образом, все респонденты, получившие низкие баллы по данной методике, то есть не имеющие нарушений пищевого поведения, были отобраны нами в качестве представителей контрольной группы, другими словами, группы условной нормы. А респонденты, получившие высокие баллы по шкалам методики КППП, 
наоборот, были отнесены к экспериментальной группе. Все респонденты, показавшие смешанные или неоднозначные результаты, были удалены из обеих групп сравнения.

Контрольную группу (КГ) составили 30 испытуемых женского пола без каких-либо нарушений в пищевом поведении. Экспериментальную группу (ЭГ) составили 30 испытуемых женского пола с явными нарушениями в пищевом поведении (по результатам тестовой диагностики).

При проведении исследования были использованы следующие методы и методики.

1. Библиографический метод - изучение научной психологической литературы по проблеме исследования.

2. Психодиагностический метод. В работе использованы следующие психодиагностические методики:

- для диагностики социально-психологических свойств личности использовался «Калифорнийский психологический опросник» (СРI) Дж.Г. Харрисона в русскоязычной модификации Н.В. Тарабриной и Н.А. Графининой (версия 1993 г.) [23];

- для диагностики пищевого поведения использовалась методика «Когнитивно-поведенческие паттерны при нарушениях пищевого поведения» 0.А. Сагалаковой и М.Л. Киселевой (версия 2014 г.) [18].

3. Для диагностики социально-психологических свойств личности использовались четыре шкалы из восьми методики «Опросник структуры темперамента» (ОСТ) В.М. Русалова (версия 1990 г.) [15; 16]. Четыре шкалы опросника ОСТ показались нам достаточно интересными с точки зрения исследуемой проблематики, и мы решили включить их в исследование. Нам кажется, что включение данных измерительных шкал поможет глубже взглянуть на социально-коммуникативную сторону вопроса. Данные шкалы отражают характер некоторых процессов, протекающих в психике человека в момент социального взаимодействия.

4. Математический метод анализа статистической значимости различий между группами: U-критерий Манна-Уитни и метод ранговой корреляции Спирмена для выявления взаимосвязей между изучаемыми признаками [4; 5].

5. Количественный и качественный анализ значимых результатов.

Подбор диагностических методик производился исходя из поставленных цели и гипотезы, а также в соответствии с проблематикой исследования.

Результаты. В ходе работы над эмпирическим исследованием были получены данные по каждой из диагностических методик, посчитаны средние значения по каждой группе. Далее мы обработали данные с помощью метода непараметрической статистики, а именно U-критерия Манна-Уитни, а также произвели расчет ранговой корреляции по Спирмену.

Таблица 1

\section{Сравнительный анализ пищевого поведения контрольной и экспериментальной групп} по методике КППП методом Манна-Уитни

\begin{tabular}{|c|c|c|c|c|c|c|c|}
\hline \multirow[b]{2}{*}{$\begin{array}{c}\text { Измерение } \\
\text { pasmruпй межқу } \\
\text { группами }\end{array}$} & \multicolumn{7}{|c|}{ Шкалы методики КПППП } \\
\hline & $\begin{array}{c}\text { Контроль над } \\
\text { употреблением } \\
\text { тшщи }\end{array}$ & $\begin{array}{c}\text { Избегание } \\
\text { объективного } \\
\text { оценивания веса, } \\
\text { в сочетании с } \\
\text { приступами } \\
\text { переедании }\end{array}$ & $\begin{array}{c}\text { Скпонность к } \\
\text { булимапи }\end{array}$ & 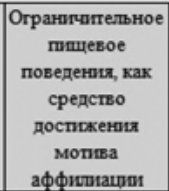 & $\begin{array}{c}\text { Эмоциогенпое } \\
\text { нарушение } \\
\text { тщщевого } \\
\text { поведения }\end{array}$ & $\begin{array}{c}\text { Самофокусировка } \\
\text { внимания на } \\
\text { недостапках } \\
\text { своего тела }\end{array}$ & $\begin{array}{c}\text { Скпонность к } \\
\text { анорексит }\end{array}$ \\
\hline $\begin{array}{c}\mu \text { для кГ, Т- } \\
\text { балл }\end{array}$ & 12 & 10 & 6 & 13 & 20 & 8 & 5 \\
\hline $\begin{array}{c}\text { Н для ЭГ, Т- } \\
\text { балл }\end{array}$ & 28 & 22 & 23 & 29 & 54 & 50 & 45 \\
\hline разница, U Эмп & $21 *$ & $15,5 *$ & $11 *$ & $13 *$ & $0 *$ & $0 *$ & $0,5 *$ \\
\hline
\end{tabular}


В таблице 1 мы видим, что средние значения контрольной группы по всем шкалам методики находятся на низком уровне. Все средние значения экспериментальной группы указывают на наличие нарушений пищевого поведения.

Абсолютно все испытуемые стараются контролировать потребление пищи, но на фоне жестких диет и излишнего внимания к недостаткам своего тела у испытуемых всё же есть сложности с самоконтролем и адекватным отношением к пище. Почти все они склонны к заеданию эмоциональных проблем, при этом паттерны булимии и анорексии часто сопутствуют друг другу, временами сменяясь то всевозможными диетами и голодом, то вновь неконтролируемым обжорством. Данная картина говорит о компульсивном характере пищевого поведения всей экспериментальной группы исследования. Трудной представляется даже попытка разграничить и обособить одни паттерны от других, так как все они единовременно содержатся в пищевом поведении респондентов группы. Следовательно, проблема нарушений пищевого поведения имеет всеобъемлющий характер и включает в себя до семи различных нарушений, что приводит нас к мысли о системности данных нарушений, идущих комплексно из внутренних социально-психологических проблем.

В ходе эмпирического исследования нами была проведена диагностика социальнопсихологических свойств личности испытуемых контрольной и экспериментальной групп по методике СРI (в адаптации Н.В. Тарабриной и Н.А. Графининой).

Таблица 2

\section{Сравнительный анализ пищевого поведения контрольной и экспериментальной групп по методике CPI методом Манна-Уитни}

\begin{tabular}{|c|c|c|c|c|c|c|c|c|c|c|}
\hline \multirow{2}{*}{$\begin{array}{l}\text { Измерение различшй } \\
\text { межку группамп }\end{array}$} & \multicolumn{10}{|c|}{ Шкалы методики CPI } \\
\hline & Do & Cs & Sy & Sp & $\mathrm{Sa}$ & In & $\mathrm{Em}$ & $\mathrm{Re}$ & So & Sc \\
\hline наля Кг, Т-6алл & 57 & 47 & 50 & 56 & 57 & 67 & 60 & 60 & 60 & 45 \\
\hline ц Аля ЭГ, Т-балл & 40 & 43 & 43 & 40 & 35 & 32 & 62 & 50 & 60 & 55 \\
\hline разница, U Эмп & $88 *$ & 366,5 & $240,5 *$ & $73,5 *$ & $30 *$ & 0 * & 359.5 & $173^{*}$ & 380,5 & 198 * \\
\hline \multicolumn{11}{|c|}{${ }^{*}$ при $p=0.01, \mu$ - среднее арифметическое } \\
\hline \multirow{2}{*}{$\begin{array}{l}\text { Измерение различий } \\
\text { межсду группами }\end{array}$} & \multicolumn{10}{|c|}{ Шкалы методики CPI } \\
\hline & Gi & $\mathrm{Cm}$ & Wb & To & Ac & Ai & le & Py & $\mathrm{Fx}$ & $\mathrm{F} / \mathrm{m}$ \\
\hline наля Кг, Т-балл & 47 & 52 & 56 & 43 & 50 & 49 & 53 & 45 & 40 & 43 \\
\hline ндля ЭГ, Т-6алл & 64 & 30 & 35 & 60 & 50 & 50 & 50 & 68 & 45 & 66 \\
\hline разница, U Эмп & $49^{*}$ & $0^{*}$ & $0 *$ & $66,5^{*}$ & 450 & 397 & 338 & $32 *$ & 335 & 33,5 * \\
\hline \multicolumn{11}{|c|}{ "при p=0.01, $\mu$ - среднее арифметическое } \\
\hline
\end{tabular}

Примечания: Do - доминирование, Cs - способность к статусу, Sy - общительность, Sp - социальное присутствие, Sa - самопринятие, In - независимость, Em - эмпатия, Re - ответственность, So - социализация, $\mathrm{Sc}$ - самоконтроль, $\mathrm{Gi}$ - хорошее впечатление, $\mathrm{Cm}$ - обычность, $\mathrm{Wb}$ - чувство благополучия, То - терпимость, Ac - достижение через подчинение, $\mathrm{Ai}$ - достижение через независимость, Iе - интеллектуальная эффективность, Ру - психологический склад ума, $\mathrm{Fx}$ - гибкость, F/m - женственность/ мужественность.

В результате математической обработки по 13 показателям из 20-и группы значимо различны между собой (табл. 2). Так, в число шкал СРI попали следующие из них: доминирование, общительность, социальное присутствие, самопринятие, независимость, ответственность, самоконтроль, хорошее впечатление, обычность, чувство благополучия, толерантность, психологический склад ума, женственность/мужественность.

По результатам диагностики с помощью методики СРІ сформировался следующий психологический портрет испытуемых ЭГ (в сравнении с респондентами КГ): это социально доста- 
точно зависимые люди, склонные следовать за группой, ведомые, конформные, избегающие соревнований и предпочитающие сотрудничество. Они достаточно пассивны и не склонны к роли лидера (респонденты КГ, наоборот, более независимы, активны, инициативны, доминантны, напористы).

Респонденты ЭГ избирательны в контактах, не слишком общительны, держат психологическую дистанцию, стараются не привлекать к себе лишнего внимания (респонденты КГ довольно активны и целеустремленны, могут вести за собой людей, открыто идут на контакт с людьми).

Кроме того, респонденты ЭГ - это люди эмпатичные, ранимые, не уверенные в себе и осторожные в общении. Они сильно зависят от чужого мнения, ищут одобрения, избегают критики, нуждаются в поддержке. Мягкие и восприимчивые (респонденты КГ, наоборот, весьма уверенные в себе, не боятся критики, спокойно относятся к мнению окружающих).

Респонденты ЭГ - это люди, чувствующие свою отчужденность от общества, подавленные. Им кажется, что они не такие, как все, особенные (респонденты КГ относятся к себе как к обычным людям, принимая себя такими, как есть. Они в целом довольны своей жизнью, и у них активная общественная позиция).

В качестве дополнительного инструмента изучения социально-психологических свойств личности испытуемых мы использовали методику ОСТ.

Таблица 3

Сравнительный анализ пищевого поведения контрольной и экспериментальной групп по методике ОСТ методом Манна-Уитни

\begin{tabular}{|c|c|c|c|c|}
\hline \multirow{2}{*}{$\begin{array}{c}\text { Измерение } \\
\text { различий между } \\
\text { группами }\end{array}$} & $\begin{array}{c}\text { Социальная } \\
\text { эргичность }\end{array}$ & $\begin{array}{c}\text { Социальная } \\
\text { пластичность }\end{array}$ & $\begin{array}{c}\text { Шоциальный } \\
\text { темп }\end{array}$ & $\begin{array}{c}\text { Социальная } \\
\text { эмоциональность }\end{array}$ \\
\hline ндля КГ, Т-балл & 10 & 8 & 7 & 6 \\
\hline$\mu$ для ЭГ, Т-балл & 3 & 7 & 8 & 10 \\
\hline разница, Ч Эмп & $36 *$ & 316 & 313,5 & $96,5 *$ \\
\hline \multicolumn{5}{|c|}{${ }^{*}$ при р=0.01, $\mu$-среднее арифметическое } \\
\hline
\end{tabular}

В таблице 3 показано, что по шкалам социальной эргичности и социальной эмоциональности группы значимо различны между собой. Респонденты КГ социально заинтересованы и активны, спокойно относятся к коммуникативным неудачам и склонны продолжать взаимодействие, стремятся к лидерству и общению. Респонденты ЭГ скорее социально пассивны, им тяжело дается коммуникативный контакт, а его неудачи воспринимаются болезненно. Они не стремятся к лидерству, внутренне эмоционально чувствительны, неуверенны в себе и достаточно закрыты.

Корреляционный анализ пищевого поведения и социально-психологических характеристик в обеих группах сравнения. Помимо проверки полученных эмпирических данных на различия между КГ и ЭГ с помощью критерия Манна-Уитни мы провели также расчет ранговой корреляции по Спирмену. Нам стало интересно, есть ли какие-либо взаимосвязи между пищевым поведением и социально-психологическими особенностями в группах испытуемых. 
Значимые показатели взаимосвязи пищевого поведения и социально-психологических характеристик в КГ по критерию Спирмена

\begin{tabular}{|c|c|c|c|c|}
\hline $\begin{array}{c}\text { Шкалы методики } \\
\text { КППП (КГ) }\end{array}$ & $\begin{array}{c}\text { Шкалы } \\
\text { сравнения }\end{array}$ & Rs $=$ & $\begin{array}{c}\text { Шкалы } \\
\text { сравнения }\end{array}$ & Rs $=$ \\
\hline $\begin{array}{c}\text { Коктроль нап } \\
\text { употреблением пиши }\end{array}$ & Sp & * -0.366 & Gi & $*-0.397$ \\
\hline $\begin{array}{l}\text { Эмоциогекное карушекие } \\
\text { пищевого поведеких }\end{array}$ & Em & $*-0.376$ & $\mathrm{~F} / \mathrm{m}$ & $*-0.384$ \\
\hline $\begin{array}{c}\text { Самофокусировка } \\
\text { вниканих на недостатках } \\
\text { своего тела }\end{array}$ & In & $*-0.376$ & $\mathrm{AC}$ & $* 0.452$ \\
\hline Скпонность х анорексии & $\mathrm{Re}$ & $*-0.376$ & Corl. эмоL- & $* 0.421$ \\
\hline $\begin{array}{l}\text { Иьбегание объективного } \\
\text { оцекиваних веса, в соч. с } \\
\text { приступами перееданих }\end{array}$ & So & $*-0.377$ & нет & нет \\
\hline Скпонность х булимии & Sc & $*-0.376$ & нет & нет \\
\hline
\end{tabular}

Примечание: * Звездочками отмечены статистически значимые показатели по результатам проведения математико-статистического анализа.

Как мы видим из таблицы 4, выявлен высокий уровень статистической значимости и наличие корреляционной связи между следующими шкалами:

- контроль над употреблением пищи (КППП) и шкалами Sp (социальное присутствие) и Gi (хорошее впечатление) методики СРI;

- избегание объективного оценивания веса в сочетании с приступами переедания и шкалой So (социализация);

- склонность к булимии и шкалой Sc (самоконтроль);

- эмоциогенное нарушение пищевого поведения и шкалами $\mathrm{Em}$ (эмпатия) и $\mathrm{F} / \mathrm{m}$ (женственность/мужественность);

- самофокусировка внимания на недостатках своего тела и шкалами In (независимость) и Ас (достижение через подчинение);

- склонность к анорексии и шкалами Re (ответственность) и шкалой социальной эмоциональности по ОСТ.

Перейдем к результатам корреляционного анализа экспериментальной группы (табл. 5).

В экспериментальной группе было зафиксировано всего четыре корреляционные связи с высоким уровнем статистической значимости:

- избегание объективного оценивания веса в сочетании с приступами переедания и шкалами Do (доминирование) и Sa (самопринятие) по методике CPI;

- эмоциогенное нарушение пищевого поведения в сочетании со шкалами Sp (социальное присутствие) и Ру (психологический склад ума).

Обсуждение и выводы. На основании количественного и качественного анализа данных можно предложить обобщенный портрет людей, страдающих от пищевых девиаций. 
Значимые показатели взаимосвязи пищевого поведения и социально-психологических характеристик в ЭГ по критерию Спирмена

\begin{tabular}{|c|c|c|}
\hline $\begin{array}{c}\text { Шкалы } \\
\text { методики КППП }\end{array}$ & $\begin{array}{c}\text { Избегание } \\
\text { объективного } \\
\text { оценивания веса, в } \\
\text { сочетании с } \\
\text { приступами } \\
\text { переедания }\end{array}$ & $\begin{array}{c}\text { Эмоциогенное } \\
\text { нарушение } \\
\text { пищевого } \\
\text { поведения }\end{array}$ \\
\hline Шкалы сравнения & Do & Sp \\
\hline Rs= & $0.369 *$ & $-0.593 *$ \\
\hline Шкалы сравнения & Sa & Py \\
\hline Rs= & $0.528 *$ & $0.431 *$ \\
\hline
\end{tabular}

Примечание: * Звездочками отмечены статистически значимые показатели по результатам проведения математико-статистического анализа.

Так, лица с нарушениями пищевого поведения могут испытывать проблемы с коммуникацией и социальным взаимодействием. Данная сфера реализации, даже при желании, для них затруднительна ввиду присущей им ранимости и тревожности. Такие люди отдалены от общества и чувствуют себя некомфортно среди большого количества людей, особенно малознакомых. Они, как правило, избегают контактов с людьми, боясь чужой критики или отвержения, нуждаются в поддержке и признании. При этом хорошие отношения им очень важны, и они стараются производить благоприятное впечатление, быть мягкими и уступчивыми. Лица с нарушением пищевого поведения доверчивы, не уверены в себе, чувствительны и озабочены тем, какое впечатление производят на окружающих. Они тяжело переживают неудачи в общении, излишне эмоциональны и восприимчивы к другим. Они воспринимают себя как особенных, но при этом сильно недовольны собой и своей жизнью.

Лица с нарушениями пищевого поведения социально пассивны и ведомы. Им тяжело выражать свою позицию, влиять на происходящее и на людей вокруг. Они чувствуют свою слабость и зависимость от людей и обстоятельств. Они конформны, предпочитают спокойствие и стабильность, не склонны делегировать свою ответственность, но при этом с трудом принимают самостоятельные решения - ищут совета и поддержки со стороны.

Заключение. Результат проведенной нами работы доказал, что проблемы пищевого поведения часто имеют комплексный характер. Склонность к анорексии может сосуществовать со склонностью к булимии и на начальной стадии иметь в себе признаки обоих нарушений, которые способны проявляться поочередно, скачкообразно, циклично, сменяя друг друга. Даже за длительным самоограничением может внезапно последовать резкий срыв. Как правило, все нарушения пищевого поведения сопровождаются недовольством своим телом, фокусировкой на его недостатках, склонностью к самоограничениям и эмоциогенному пищевому поведению.

Кроме того, результаты показали, что все нарушения пищевого поведения сопровождаются достаточно конкретными социально-психологическими проблемами (дисфункциональными особенностями), которые являются довольно типичными для представителей данной 
группы людей. Коррекционную терапию необходимо сконцентрировать на самом клиенте и его взаимоотношениях с собой и с внешним миром.

Программа терапии пищевых нарушений обязательно должна включать в себя следующие этапы:

1) коррекция отношений между клиентом и пищей, работа со смыслами;

2) коррекция отношения клиента к самому себе, работа с образом «я» и убеждениями;

3) нормализация и укрепление самооценки, выработка уверенности в себе;

4) выяснение системы ценностей и желаний;

5) диагностика страхов и опасений, развитие смелости и осознания собственных возможностей;

6) работа над самопринятием и естественностью;

7) коррекция эмоциональной сферы, установление правильных психологических границ;

8) развитие навыков общения, решения конфликтов, отстаивания своих интересов;

9) развитие навыков эффективного преодоления стресса;

10) коррекция питания и образа жизни (вторичная работа).

Данные рекомендации могут успешно реализовываться как в групповой, так и в индивидуальной работе с клиентами, хотя второе, конечно, предпочтительнее, так как необходимо учитывать такие индивидуальные факторы жизни клиента, как ситуация в семье, история возникновения и развития нарушений, особенности личности клиента, позволяющие подобрать методы, наиболее подходящие для работы с данным клиентом, и т.д. Групповые занятия могут стать качественным дополнением к индивидуальной работе на этапе осознания проблем и при переходе к этапу развития реальных навыков. В группе людей со сходными проблемами клиенту будет гораздо проще расслабиться и раскрыться.

Данные рекомендации будут полезны для практики психологов таких направлений, как когнитивно-поведенческая психотерапия, телесно-ориентированная психотерапия, гештальт-терапия и психоанализ.

\section{Список литературы}

1. Вахмистров А.В., Вознесенская Т.Г., Посохов С.И. Клинико-психологический анализ нарушений пищевого поведения при ожирении // Журнал невропатологии и психиатрии имени С.С. Корсакова. 2001. № 12. С. 19-24.

2. Вознесенская Т.Г. Ожирение. Глава 9. Типология нарушений ПП и эмоционально-личностные расстройства при первичном ожирении и их коррекция. М., 2010. С. 236-256.

3. Вознесенская Т.Г. Расстройства пищевого поведения при ожирении и их коррекция // Ожирение и метаболизм. 2004. Т. 2. С. 2-6.

4. Дружинин В.Н. Экспериментальная психология: учебник для вузов. 2-е изд. СПб.: Питер, 2008.

5. Ермолаев 0.Ю. Математическая статистика для психологов: учебник. 7-е изд., стер. М.: Флинта, 2019. URL: https://rucont.ru/efd/244852.

6. Макарова Е.В. Психологические аспекты нарушения пищевого поведения // Научное сообщество студентов XXI столетия. Гуманитарные науки: матер. LIV Междунар. студ. науч.практ. конф.: сб. ст. 2017. № 6 (54). URL: https://sibac.info/archive/guman/6(54).pdf (дата обращения: 24.06.2019).

7. Малкина-Пых И.Г. Лишний вес. Освободиться и забыть. Навсегда. М.: Эксмо, 2007. 432 с.

8. Малкина-Пых И.Г. Терапия пищевого поведения. М.: Эксмо, 2007. 1040 с.

9. Марилов В.В., Артемьева М.С., Сулейманов Р.А. и др. Результаты длительного исследования нарушений пищевого поведения // Вестник Российского университета дружбы народов. 2006. № 2. URL: http://cyberleninka.ru/article/n/rezultaty-dlitelnogo-issledovaniyanarusheniy-pischevogo-povedeniya.

10. Менделевич В.Д. Клиническая медицинская психология. М.: МЕДпресс, 2014. 360 с.

11. Менделевич В.Д. Пищевые зависимости, аддикции - нервная анорексия, нервная булимия // Руководство по аддиктологии. СПб.: Речь, 2007. 
12. Николаева Н.О. История и современное состояние исследований нарушений пищевого поведения (культурные и психологические аспекты) // Клиническая и специальная психология. 2012. № 1. URL: http://psyjournals.ru/psyclin/2012/n1/49969_full.shtml.

13. Николаева Н.О., Мешкова Т.А. Нарушения пищевого поведения: социальные, семейные и биологические предпосылки // Вопросы психического здоровья детей и подростков. 2011. № 1 (11). С. 39-49.

14. Пономарева Л.Г. Современные представления о расстройствах пищевого поведения // Молодой ученый. 2010. № 10. С. 274-276.

15. Русалов В.М. Опросник структуры темперамента. М., 1990.

16. Русалов В.М. Темперамент в структуре индивидуальности человека. Дифференциальнопсихофизиологические и психологические исследования. М.: Изд-во ИП РАН, 2012.

17. Савчикова Ю.Л. Психологические особенности женщин с проблемами веса: дис. ... канд. психол. наук. СПб.: СПбГУ, 2005.

18. Сагалакова 0.А., Киселева М.Л. Когнитивно-поведенческие паттерны при нарушениях пищевого поведения в контексте социальной тревоги // Клиническая и медицинская психология: исследования, обучение, практика. 2013. № 1 (1). URL: http://medpsy.ru/climp.

19. Сивуха С.В., Скугаревский О.А., Нарушения пищевого поведения и возможность их скрининговой оценки // Вопросы организации и информатизации здравоохранения. 2003. № 3. С. 41-44.

20. Скугаревский 0.А. Классификационные критерии нарушений пищевого поведения и сопряженные поведенческие проявления // Психотерапия и клиническая психология. 2003. № 2 (7). С. 25-29.

21. Скугаревский 0.А. Феномен «пересечения контекстов» в неодолимом стремлении к совершенству... при нарушениях пищевого поведения // Актуальные вопросы психического здоровья: матер. Междунар. науч.-практ. конф., посвящ. 10-летию кафедры медицинской психологии и психотерапии (Гродно, 21 января 2005 г.): сб. науч. работ. 2005. С. 162-164.

22. Соколова Е.Т. Самосознание и самооценка при аномалиях личности. М.: МГУ, 2008. 387с.

23. Тарабрина Н.В., Графинина Н.А. Новый вариант Калифорнийского психологического опросника // Методики анализа контроля трудовой деятельности и функционального состояния: сб. М., 1993.

24. Фролова Ю.Г., Скугаревский О.А. Социальные факторы формирования негативного образа тела // Социология. 2004. № 2. С. 61-68.

25. Шабанова Т.Л. Исследование нарушений пищевого поведения у лиц юношеско-студенческого возраста // Международный журнал прикладных и фундаментальных исследований. 2017. № 9. С. 91-95.

\section{References}

1. Vakhmistrov A.V., Voznesenskaya T.G., Posokhov S.I. Kliniko-psikhologicheskij analiz narushenij pishchevogo povedeniya pri ozhirenii // Zhurnal nevropatologii i psikhiatrii imeni S.S. Korsakova. 2001. № 12. S. 19-24.

2. Voznesenskaya T.G. Ozhirenie. Glava 9. Tipologiya narushenij PP i emocional'no-lichnostnye rasstrojstva pri pervichnom ozhirenii i ikh korrekciya. M., 2010. S. 236-256.

3. Voznesenskaya T.G. Rasstrojstva pishchevogo povedeniya pri ozhirenii i ikh korrekciya // Ozhirenie i metabolizm. 2004. T. 2. S. 2-6.

4. Druzhinin V.N. Eksperimental'naya psikhologiya: uchebnik dlya vuzov. 2-e izd. SPb.: Piter, 2008.

5. Ermolaev 0.Yu. Matematicheskaya statistika dlya psikhologov: uchebnik. 7-e izd., ster. M.: Flinta, 2019. URL: https://rucont.ru/efd/244852.

6. Makarova E.V. Psikhologicheskie aspekty narusheniya pishchevogo povedeniya // Nauchnoe soobshchestvo studentov XXI stoletiya. Gumanitarnye nauki: mater. LIV Mezhdunar. stud. nauch.-prakt. konf.: sb. st. 2017. № 6 (54). URL: https://sibac.info/archive/guman/6(54). pdf (data obrashcheniya: 24.06.2019).

7. Malkina-Pykh I.G. Lishnij ves. Osvobodit'sya i zabyt'. Navsegda. M.: Eksmo, 2007. $432 \mathrm{~s}$.

8. Malkina-Pykh I.G. Terapiya pishchevogo povedeniya. M.: Eksmo, 2007. $1040 \mathrm{~s}$.

9. Marilov V.V., Artem'eva M.S., Sulejmanov R.A. i dr. Rezul'taty dlitel'nogo issledovaniya narushenij pishchevogo povedeniya // Vestnik Rossijskogo universiteta druzhby narodov. 2006. № 2. URL: http://cyberleninka.ru/article/n/rezultaty-dlitelnogo-issledovaniyanarusheniy-pischevogo-povedeniya.

10. Mendelevich V.D. Klinicheskaya medicinskaya psikhologiya. M.: MEDpress, 2014. 360 s. 
11. Mendelevich V.D. Pishchevye zavisimosti, addikcii - nervnaya anoreksiya, nervnaya bulimiya // Rukovodstvo po addiktologii. SPb.: Rech', 2007.

12. Nikolaeva N.0. Istoriya i sovremennoe sostoyanie issledovanij narushenij pishchevogo povedeniya (kul'turnye i psikhologicheskie aspekty) // Klinicheskaya i special'naya psikhologiya. 2012. № 1. URL: http://psyjournals.ru/psyclin/2012/n1/49969_full.shtml.

13. Nikolaeva N.O., Meshkova T.A. Narusheniya pishchevogo povedeniya: social'nye, semejnye i biologicheskie predposylki // Voprosy psikhicheskogo zdorov'ya detej i podrostkov. 2011. № 1 (11). S. 39-49.

14. Ponomareva L.G. Sovremennye predstavleniya o rasstrojstvakh pishchevogo povedeniya // Molodoj uchenyj. 2010. № 10. S. 274-276.

15. Rusalov V.M. Oprosnik struktury temperamenta. M., 1990.

16. Rusalov V.M. Temperament $v$ strukture individual'nosti cheloveka. Differencial'nopsikhofiziologicheskie i psikhologicheskie issledovaniya. M.: Izd-vo IP RAN, 2012.

17. Savchikova Yu.L. Psikhologicheskie osobennosti zhenshchin s problemami vesa: dis. ... kand. psikhol. nauk. SPb.: SPbGU, 2005.

18. Sagalakova O.A., Kiseleva M.L. Kognitivno-povedencheskie patterny pri narusheniyakh pishchevogo povedeniya $v$ kontekste social'noj trevogi // Klinicheskaya i medicinskaya psikhologiya: issledovaniya, obuchenie, praktika. 2013. № 1 (1). URL: http://medpsy.ru/ climp.

19. Sivukha S.V., Skugarevskij 0.A., Narusheniya pishchevogo povedeniya i vozmozhnost' ikh skriningovoj ocenki // Voprosy organizacii i informatizacii zdravookhraneniya. 2003. № 3. S. 41-44.

20. Skugarevskij 0.A. Klassifikacionnye kriterii narushenij pishchevogo povedeniya i sopryazhennye povedencheskie proyavleniya // Psikhoterapiya i klinicheskaya psikhologiya. 2003. № 2 (7). S. 25-29.

21. Skugarevskij 0.A. Fenomen «peresecheniya kontekstov» $v$ neodolimom stremlenii $\mathrm{k}$ sovershenstvu... pri narusheniyakh pishchevogo povedeniya // Aktual'nye voprosy psikhicheskogo zdorov'ya: mater. Mezhdunar. nauch.-prakt. konf., posvyashch. 10-letiyu kafedry medicinskoj psikhologii i psikhoterapii (Grodno, 21 yanvarya 2005 g.): sb. nauch. rabot. 2005. S. 162-164.

22. Sokolova E.T. Samosoznanie i samoocenka pri anomaliyakh lichnosti. M.: MGU, 2008. 387s.

23. Tarabrina N.V., Grafinina N.A. Novyj variant Kalifornijskogo psikhologicheskogo oprosnika // Metodiki analiza kontrolya trudovoj deyatel'nosti i funkcional'nogo sostoyaniya: sb. M., 1993.

24. Frolova Yu.G., Skugarevskij 0.A. Social'nye faktory formirovaniya negativnogo obraza tela // Sociologiya. 2004. № 2. S. 61-68.

25. Shabanova T.L. Issledovanie narushenij pishchevogo povedeniya u lic yunosheskostudencheskogo vozrasta // Mezhdunarodnyj zhurnal prikladnykh i fundamental'nykh issledovanij. 2017. № 9. S. 91-95.

\section{Библиографическое описание статьи / Reference to article}

Петрова Е.А., Хожеева К.С. Социально-психологические особенности лиц с нарушениями пищевого поведения // Ученые записки Российского государственного социального университета. T. 19. 2020. № 1 (154). C. 96-105. D0I: 10.17922/2071-5323-2020-19-1-96-105 (Библиографическое описание согласно российским стандартам).

Petrova E.A., Khozheeva K.S. Social'no-psikhologicheskie osobennosti lic s narusheniyami pishchevogo povedeniya // Uchenye zapiski Rossijskogo gosudarstvennogo social'nogo universiteta. T. 19. 2020. № 1 (154). S. 96-105. DOI: 10.17922/2071-5323-2020-19-1-96105 (Reference in Roman script).

Petrova, E.A. \& Khozheeva, K.S. (2020) Socio-Psychological Characteristics of People with Eating Disorders, Scientific Notes of Russian State Social University. Vol. 19. No. 1 (154). P. 96105. DOI: 10.17922/2071-5323-2020-19-1-96-105 (International bibliographic description). 


\title{
ОБРАЗОВАНИЕ ИПЕААГОГИКА
}

\section{Н.И. Ануфриева,}

д-р пед. наук, профессор, заведующая кафедрой социологии и философии культуры, директор Высшей школы музыки им. А. Шнитке (институт),

Российский государственный социальный университет, Москва.

N.I. Anufrieva,

doctor of pedagogical sciences, professor, head of the department of sociology and philosophy of culture, director Higher school of music n.a. A. Schnittke (institute), Russian State Social University, Moscow.

E-mail: nata415485@mail.ru

\section{Современные методы постановки голоса в процессе обучения педагогов-музыкантов}

\author{
Modern Methods of Voice Statement \\ in the Process of Teaching Teachers-Musicians
}

Дата поступления 25.12.2019
Дата препринта

28.02.2020
Дата публикации

30.03.2020

Аннотация: современное музыкальное образование предъявляет достаточно высокие требования к подготовке специалистов разных сфер культуры и искусства. «Педагог-музыкант» - это достаточно широкое понятие, охватывающее обширное поле деятельности в области обучения и воспитания музыке подрастающего поколения: это вокалист, инструменталист, преподаватель музыкально-теоретических дисциплин и др. В настоящей статье рассматривается проблема постановки голоса педагога-музыканта, работающего в учреждениях общего и дополнительного образования. В актуальные задачи его подготовки входит овладение универсальными компетенциями, прочными музыкально-теоретическими знаниями и навыками, умениями работать с обучающимися разных возрастов.

Annotation: modern musical education places quite high demands on the training of specialists in various spheres of culture and art. "The teacher-musician" is quite a broad concept, covering an extensive field of activity in the field of education and education of music of the younger generation: it is a vocalist, an instrumentalist, a teacher of musical and theoretical disciplines, etc. This work deals with the problem of the voice of a teacher-musician working in institutions of general and additional education. Relevant problems of its preparation include mastering universal competences, strong musical and theoretical knowledge and skills, abilities to work with students of various ages.

Ключевые слова: педагог-музыкант, постановка голоса, обучение пению, профессиональная подготовка, методика обучения.

Key words: teacher-musician, voice training, training in singing, vocational training, training technique.

Введение. Постановка голоса является важной частью профессионального обучения педагога-музыканта и включает в себя целый комплекс проблем, связанных с положением гор- 
тани, работой брюшной полости, техникой подачи звука, развитием дыхательного аппарата, формированием и совершенствованием дикции обучающегося. Необходимо также учитывать особенности звукоизвлечения, достичь чистоты интонации и ритмической точности.

Вокальное воспитание и обучение будущих педагогов-музыкантов является необходимой частью их профессионального становления [18]. В отличие от концертирующего вокалиста артиста музыкального театра, солиста филармонии - педагог-музыкант не выступает как солист перед большой аудиторий. Однако владение навыками пения для него необходимо в той мере, в какой он отвечает за качество учебно-воспитательного процесса.

Современный уровень образования отличается высокой степенью развития методик обучения, мультимедийных технических средств, программно-компьютерного обеспечения. Благодаря Интернету можно самостоятельно обучаться пению по аудио- и видеозаписям или заниматься с профессиональным педагогом дистанционно в онлайн-режиме. Многие современные педагоги применяют возможности современных средств коммуникации в обучении студентов и постановке голоса у будущих педагогов-музыкантов [18].

Однако наряду с качественными аудио- и видеозаписями наиболее эффективным методом занятия музыкой был и остается живой показ педагога, звучание живой музыки. Демонстрационный метод на сегодняшний день не теряет своей актуальности, но он совершенствуется благодаря отбору упражнений и заданий, приносящих в ходе постановки голоса наиболее ощутимый эффект. Современные методы постановки голоса, таким образом, являются синтетическими и соединяют в себе высшие достижения педагогов-вокалистов прошлого. В российских музыкально-педагогических вузах и вузах культуры и искусства применяют методы постановки голоса, разработанные Н.Б. Гонтаренко, К. Плужниковым, В.П. Морозовым, А.Г. Менабени, В.И. Юшматовым и другими. При этом в постановке голоса используется индивидуально-личностный подход к каждому студенту для достижения наибольших результатов обучения.

Методы и методология. Основой исследования служат научно-педагогические и методические разработки в области вокальной педагогики М.С. Эрбштейн, С.М. Сонки, Л.Б. Дмитриева, 0.А. Савчук, Н.П. Варшавской, Л.Г. Боровик, Е.В. Алтуховой, А.В. Басовой, Ю.Б. Эдельман, Е.Г. Малышевой, А.Ю. Крылова и др. В исследованиях К.И. Плужникова, Ю.В. Савельевой, М.С. Эрбштейн, С.М. Сонки, Ю.Б. Эдельмана, А.В. Басовой, Л.Г. Боровик, Н.П. Варшавской, Ю.С. Василенко, Л.Б. Дмитриева, Н.Р. Усаевой представлен анализ проблем звукообразования, в частности строения гортани, дыхательных органов человека, обоснована роль каждого органа в формировании звука.

В исследованиях Е.Г. Малышевой и А.Ю. Крылова анализируются проблемы формирования речевой и певческой интонации. М.С. Эрбштейн, С.М. Сонки, Л.Б. Дмитриев обращают внимание на физиологические основы постановки голоса. 0.А. Савчук исследует эмоциональные и психотерапевтические аспекты занятий вокалом. А.В. Басова и Е.Ю. Медведева обращают внимание на особенности певческой артикуляции, причем Е.Ю. Медведева акцентирует вопросы фонетического воспитания педагога-музыканта, поскольку основой его педагогической деятельности является не только вокал, но и грамотная, фонетически осмысленная литературная речь. Т.Д. Смелкова, Ю.В. Савельева обосновывают понятие «осмысленное интонирование», необходимое в методике постановки голоса и вокального воспитания педагога-музыканта.

Методами исследования послужили: анализ существующей научной литературы, посвященной постановке голоса, музыкально-педагогической и вокально-исполнительской подготовке в целом; педагогическое наблюдение и обобщение практического опыта; применение существующих современных методов постановки голоса и выявление особенностей процесса постановки голоса у педагогов-музыкантов в практической педагогической деятельности.

Результаты. Обосновывая главные принципы постановки голоса у педагога-музыканта, опишем авторскую методику обучения, успешно применяемую на занятиях вокалом в му- 
зыкально-педагогических колледжах и вузах России с начала 2000-х годов. Данная методика разработана концертирующими солистами-вокалистами, в течение более 10 лет занимающимися педагогической деятельностью в вузах и работающими как с бакалаврами, так и с магистрами $[1 ; 4 ; 6 ; 7 ; 11 ; 15 ; 17 ; 20]$. При этом в ней применены традиционные подходы и научные разработки прошлого $[2 ; 3 ; 5 ; 8 ; 12 ; 16 ; 19]$. Благодаря данной методике студенты ведут успешную музыкально-исполнительскую и педагогическую деятельность, участвуют в конкурсах, становятся лауреатами и дипломантами фестивалей. Эффективность методики обусловлена рядом факторов, включая задачи обучения, комплекс специальных упражнений, деление урока на подготовительную и основную части, правильно организованную работу над вокализами и учебным репертуаром.

Процесс вокального обучения будущих педагогов-музыкантов на основе предложенной методики включает в себя следующие задачи:

1) формирование основных элементов вокальной техники;

2) работа над вокализами;

3) изучение репертуара (работа над музыкальным произведением).

Все указанные задачи взаимосвязаны и выполняются в комплексе. Например, формирование основных элементов вокальной техники необходимо сочетать с работой над вокализами, в которых отрабатывается техника пения, изучением репертуара и т.д.

Использование разных упражнений на подготовительном этапе урока вокала может быть варьировано в зависимости от степени подготовки обучающегося и его индивидуальных задач. В процессе подготовительного этапа урока возможны следующие упражнения: для языка, гортани, нижней челюсти, подвижности губ, произношения согласных звуков, сочетания согласных и гласных в речи.

Одной из проблем дикции является четкое и правильное произношение твердой согласной «р». Без нее очень трудно обойтись при исполнении вокальных произведений классики и современности. Для решения проблемы артикуляции согласной «р» используются упражнения в практической работе с теми обучающимися, у которых имеются проблемы с произношением этого звука. Кроме того, они полезны для всех студентов-вокалистов.

В основной части урока необходимо активизировать голосовой аппарат обучающегося с помощью вокальных упражнений, вокализов, а также работы над репертуаром. В научнометодическом исследовании М.А. Павловой представлены основные требования пения.

1. «Вдох необходимо осуществлять через нос в нижнюю часть легких, особенно в начале обучения. В этом случае легкие полностью наполняются воздухом, и область диафрагмы расширяется.

2. Набирать достаточное количество воздуха, то есть столько, чтобы не было переполненности в грудной клетке. Затем, зафиксировав это состояние, сомкнуть связки одновременно с подачей воздуха из легких. При этом нужно следить, чтобы диафрагма не теряла своей упругости и оставалась в том же положении, в каком оказалась при вдохе - опущенном.

3. Стараться петь без толчков, ровным звуком.

4. Сохранять высокую позицию при переходе от высоких нот на более низкие, то есть не терять ощущения высоты звука на всем диапазоне.

5. Маленький язычок сохранять в состоянии зевка, то есть максимально поднятым. Тогда звук будет округлым и не встретит препятствия при выходе из гортани. Звук направлять в область передних зубов, обеспечивая близкое и яркое звучание.

6. Внимательно следить за чистотой интонации, не допускать фальши» [9, с. 13-14].

обсуждение. Помимо упражнений на основном этапе урока необходимо работать над вокализами. Желательно использовать сборники Ф. Абта, Н. Воккаи, А. Варламова. В процессе работы над вокализами обучающийся овладевает певческими навыками. На первом этапе обучения педагогу необходимо фиксировать задержку дыхания, взятого учеником на три секунды, после чего начинать звук. Извлекаемый звук должен свободно вибрировать. 
Важно проследить, чтобы обучающийся не увеличивал силу звука до чрезмерной напряженности, не свойственной природе данного голоса. Необходимо формировать хороший зевок, который приводит все части рта в нужное положение. Подбор вокализов для обучающихся пению должен отвечать следующим критериям:

- кантилена без технических сложностей. При звуковедении обучающийся не должен менять позиции, не снимать голос с опоры;

- развитие вокально-технических навыков, слуховой и мышечной координации в тесной взаимосвязи с музыкальным слухом;

- использование гласных.

По утверждению К.И. Плужникова, «звуки человеческого голоса - не что иное, как гласные, подвергающиеся бесчисленным изменениям. В вокальном исполнительстве существуют два главных тембра: открытый (светлый) и закрытый (темный): светлый - для одной части светлых и низких нот и темный - для нот высоких. Границей обоих тембров можно брать среднее соль. Вверх от ноты “соль" гласная "A" должна постепенно округляться по схеме “А-0-У"» [10, с. 11].

Работа над вокализами дает голосу необходимые навыки овладения вокальной техникой: дыханием, атакой звука, движением гортани, работой над гласными. Необходима тесная связь вокализов с упражнениями для голоса, используемыми в начале основного этапа урока. Важно настроить обучающегося на понимание того, что упражнения и вокализы - это отнюдь не «служебная» часть работы; их нужно исполнять с той же степенью выразительности, что и художественное произведение классической либо современной музыки.

В основе изучения репертуара лежит осмысленное интонирование. В книге Т.Д. Смелковой и Ю.В. Савельевой [14] дано понимание исполнительского искусства вокалиста как искусства интонирования: «Выразительность в пении связана не только с точным выполнением темповых, динамических и других указаний композитора, но и особого отношения к процессу пения, не точечного воспроизведения нотного текста ("скакания по интервалам", “пения нот"), а напряженного “переживания", “вчувствования" в каждую интонацию, в каждую фразу» [13, с. 49-50].

Осмысленное интонирование включает в себя следующие аспекты исполнения:

1) понимание композиторского замысла, стилистических особенностей; ладовой и метроритмической структуры вокального произведения;

2) осознание композиции (формы), кульминационных точек развития;

3) работа над соотношением поэтического (прозаического) и музыкального текста, фразировкой, динамикой;

4) представление о возможностях воспитательного, культурно-просветительского направления в исполнении вокального произведения перед детской / подростковой аудиторией.

Важной особенностью программы дисциплины «Музыка» является постоянное обращение к классике. Творчество А.С. Пушкина и М.И. Глинки - поэта и композитора - принадлежит к «золотым страницам» отечественной культуры. Академические певцы часто обращаются к опере Глинки «Руслан и Людмила», созданной по одноименной поэме Пушкина. Проанализируем особенности исполнения каватины Гориславы из оперы Глинки.

Исполнителю необходимо познакомиться с историей создания каватины. Горислава - это новая возлюбленная хазарского хана Ратмира. Однако в поэме А.С. Пушкина она упоминается лишь вскользь. Это пастушка; поэт даже не дает ей имени. Но Ратмиру она оказалась дороже всех. В песне 5-й Ратмир, увидев Руслана со спящей Людмилой, говорит такие слова: «Возможно ли, какой судьбою, что слышу? Русская княжна?

Она с тобою, где ж она? Позволь...но нет, боюсь измены.

Моя подруга мне мила. Моей счастливой перемены она виновницей была.

Она мне жизнь, она мне радость! Она мне возвратила вновь 
Мою утраченную младость, и мир, и чистую любовь.

Напрасно счастье мне сулили уста волшебниц молодых.

12 дев меня любили, я для нее покинул их,

Оставил терем их веселый в тени хранительных дубров

Сложил и меч, и шлем тяжелый, забыл и славу, и врагов.

Отшельник милый и безвестный остался в счастливой глуши

С тобой, друг милый и прелестный, с тобою, свет моей души!»

В опере Глинки избранница Ратмира получает имя - Горислава. Это старославянское имя; его значение - яркая, славная, высокочтимая. Женщина с таким именем любит беззаветно и навсегда. Горислава в опере - одна из пленниц гарема. В арии есть слова о том, что не всегда платок избранницы доставался ей. Но Горислава готова идти за своим возлюбленным хоть на край света...Текст для Гориславы написал не Пушкин, а поэт Валериан Ширков, либреттист оперы «Руслан и Людмила». Образ беззаветно, искренне любящей женщины наделен в опере подлинным драматизмом. Для вокальной партии характерны широкие скачки в пределах октавы, ходы по звукам $M_{53}$ (тоническое трезвучие тональности a-moll). Форма каватины - куплетно-вариационная: A (такты 1-35) - A $_{1}$ (такты 36-80) - A $_{2}$ (такты 81-117) + оркестровое заключение (такты 118-127).

Начальная сдержанность чувства «Любви роскошная звезда» постепенно переходит в драматический монолог: Горислава полна решимости следовать за своим возлюбленным. Вокалисту необходимо распеть гласные «о» (роскооошная), «и» (ты закатииилась). Смысловое ударение падает именно на середины фраз, окончания - мягкие, с оттенком безысходности. Необходимо обратить внимание на темп - Allegretto agitato - подвижно, страстно; важно не ускорять движение, почувствовать внутреннюю силу персонажа. Далее - своеобразный припев «0, моой Ратмир! Любоовь и мир! В родной приют тебяа зовут!» спеть мягко, доверительно (ремарка композитора dolce). Припев повторяется в конце каждого раздела каватины, служит выражением глубокого чувства любви.

Следующая фраза «Ужели мне во цвете лет сказать любви “Прости навек, прости навек, прости навек"» (такты 22-28) построена по хроматическим интонациям, причем в тактах 22-24 можно услышать мелодию, предвосхищающую тему Татьяны из оперы «Евгений 0негин» П.И. Чайковского. Кульминация первого раздела каватины происходит в тактах 25-26 фраза «Простии наавееэк» распета в широком диапазоне от ми первой октавы до ля второй. В окончании первого раздела каватины (такты 28-35) желательно снять напряжение: Горислава утверждает то, что уже было спето, прочувствовано.

Во втором разделе $\mathrm{A}_{1}$ Горислава рассказывает, что любовь к Ратмиру затмила тоску по Родине. Она ревнует, но прячет свои чувства. Платок избранницы хан иногда бросал не ей! В мелодии и гармонии звучит неаполитанский аккорд: начиная с творчества А. Скарлатти, он служит выражением глубокого чувства печали, близкого к скорби. Эллиптические последовательности усиливают состояние неустойчивости, волнения; в тактах 41-53 Глинка использует интонацию passus durisculus (от лат. - жесткий ход) - ее нужно пропеть максимально точно, как бы «скользя» по полутонам.

В третьем разделе $A_{2}$ Горислава повествует о том, что она отправляется в путь за своим возлюбленным. Вокалисту необходимо почувствовать волю, решимость Гориславы; особенно выразительны восходящие и нисходящие скачки на кварту, квинту, септиму, требующие широкого дыхания. Конец третьего раздела (такты 99-117) является кульминацией каватины. В устах Гориславы звучит призыв: «0, возвратись на брег родной!». Звучание голоса forte - поддержано оркестровым tremolo.

Дисциплина «Музыка» в общеобразовательной школе знакомит детей и подростков с классическим искусством. Педагогу необходимо обеспечить связь музыки с литературой и поэзией. Школьники, изучая творчество А.С. Пушкина, обращаются к его произведениям как в начальный, так и в более поздний периоды обучения. Сказки великого поэта - это 
настоящий кладезь мудрости. Поэма «Руслан и Людмила», знакомая всем с раннего детства, наполняется новым содержанием в опере М.И. Глинки. Педагогу-музыканту необходимо раскрыть детям музыкальный мир пушкинской сказки, показать различные грани образов Руслана, Людмилы, Ратмира, Гориславы, Финна, Наины, Черномора. В каватине Гориславы реализуется высокий духовный потенциал русской женщины, воспетый многими поэтами, писателями, композиторами.

Выводы. Проблема вокального обучения педагога-музыканта является неотъемлемой частью его профессионального образования. Знание основ истории, теории музыкального и, в частности, вокального искусства, особенностей постановки голоса в речевой и певческой интонации, дикции, дыхания, элементов актерского мастерства подготовят педагога к позитивному настрою в его будущей учебно-воспитательной деятельности. Педагог-музыкант, владеющий вокалом, имеет огромные перспективы в обучении и воспитании подрастающего поколения.

Современному педагогу-музыканту необходимо обладать достаточно высоким уровнем профессиональной подготовки, включающем в себя: знания в области истории, литературы, поэзии, разных видов искусства; владение грамотной речью, музыкально-теоретическими и музыкально-историческими сведениями; владение музыкально-инструментальными и вокальными навыками. Область вокальной музыки занимает значительное место в его образовании.

Обучение вокалу педагога-музыканта направлено на формирование его исполнительской культуры. Умение спеть музыкальное произведение классики либо современности открывает широкие возможности духовного общения с детской и подростковой аудиторией и является мощным стимулом для совершенствования учебно-воспитательного процесса по дисциплине «Музыка» в общеобразовательной школе и учреждении дополнительного образования. Более того, профессиональное владение голосом открывает широкие возможности для развития различных компетенций в областях культурно-просветительской и научно-исследовательской деятельности.

Особенности дыхания, звукообразования, дикции - все эти задачи, решаемые в процессе обучения, находятся в прямой связи с качеством постановки голоса педагога-музыканта. Использование вокализов служит важным подспорьем в работе педагога и обучающегося, а освоение учебного репертуара дает возможность педагогу-музыканту овладеть материалом, которым он будет пользоваться в процессе музыкального воспитания детей и подростков. Помимо технических задач в вокальной подготовке большое внимание уделяется вокальному репертуару. Следует учитывать художественную ценность исполняемых произведений, индивидуальность каждого студента, его художественный вкус, возможности, эстетические потребности. Важной особенностью подбора репертуара для педагогов-музыкантов является постоянная связь с программой «Музыка» общеобразовательной школы и программами музыкального воспитания учреждений дополнительного образования.

\section{Список литературы}

1. Басова А.В. Основы вокальной методики. Оренбург: ИПк гоу ОГУ, 2010. 105 с.

2. Боровик Л.Г. Научные основы постановки голоса. Челябинск, 2013. 106 с.

3. Варламов А.Е. Полная школа пения: учеб. пособие. 4-е изд. СПб.: Лань : Планета музыки, 2012. 120 C.

4. Варшавская Н.П. Некоторые принципы вокальной методики. Казань: Казан. гос. консерватория (академия), 2007. 28 с.

5. Василенко Ю.С. Голос. Фониатрические аспекты. М.: Дипак, 2013. 396 с.

6. Малышева Е.Г., Крылов А.Ю. Постановка голоса. Техника речи. Омск: Омск. гос. ун-т им. Ф.М. Достоевского, 2017. 244 С.

7. Миценко Г.И. Основы методики сольного пения. М.: МГУкИ, 2006. 30 с.

8. Морозов В.П. Искусство резонансного пения. М.: Искусство, 2002. 256 с. 
9. Павлова М.А. Лекции по методике обучения сольному пению. М.: Моск. гос. откр. ун-т им. М.А. Шолохова, 2004. 87 с.

10. Плужников К.И. Механика пения. Принципы постановки голоса: учеб. пособие. 2-е изд. СПб.: Лань : Планета музыки, 2013. 96 с.

11. Прянишников К.И. Советы обучающимся пению: учеб. пособие. 6-е изд. СПб.: Лань : Планета музыки, 2013. 144 с.

12. Рахчеев Н.В. Постановка голоса и методика обучения пению. Минск, 1988. 145 с.

13. Решетникова Т.В. Формирование вокальных навыков на уроках сольного пения // Традиции и инновации в современном культурно-образовательном пространстве: матер. IX Междунар. науч.-практ. конф. М.: МГПУ, 2019. 225 с.

14. Савельева Ю.В., Смелкова Т.Д. Основы обучения вокальному искусству. СПб.: Лань : Планета музыки, 2014. 160 с.

15. Смелкова Т.Д. Основы обучения вокальному искусству. СПб.: Композитор, 2014. 154 с.

16. Сонки С.М. Теория постановки голоса в связи с физиологией органов, воспроизводящих звук. М.: Либроком, 2014. 248 с.

17. Стахеева М.В. Вокальная подготовка иностранных обучающихся (к вопросу международного сотрудничества Хабаровского государственного института культуры) // Вопросы развития творческой среды Дальнего Востока России и Азиатско-Тихоокеанского региона: матер. Междунар. науч.-практ. конф., посвящ. 50-летию ХГИК. Хабаровск, 2018. С. 217222.

18. Урбанович Г.И. Певческий голос учителя музыки // Музыкальное воспитание в школе: сб. Ст. М., 1997. С. 12-16.

19. Эдельман Ю.Б. Уроки пения. М.: Торус Пресс, 2010. 176 с.

20. Эрбштейн М.С. Краткий курс практических уроков пения. М.: Музыка, 1989. 76 с.

\section{References}

1. Basova A.V. Osnovy vokal'noj metodiki. Orenburg: IPK GOU OGU, 2010. 105 s.

2. Borovik L.G. Nauchnye osnovy postanovki golosa. Chelyabinsk, 2013. $106 \mathrm{~s}$.

3. Varlamov A.E. Polnaya shkola peniya: ucheb. posobie. 4-e izd. SPb.: Lan' : Planeta muzyki, 2012. $120 \mathrm{~s}$.

4. Varshavskaya N.P. Nekotorye printsipy vokal'noj metodiki. Kazan': Kazan. gos. konservatoriya (akademiya), 2007. $28 \mathrm{~s}$.

5. Vasilenko Yu.S. Golos. Foniatricheskie aspekty. M.: Dipak, 2013. $396 \mathrm{~s}$.

6. Malysheva E.G., Krylov A.Yu. Postanovka golosa. Tekhnika rechi. Omsk: Omsk. gos. un-t im. F.M. Dostoevskogo, 2017. 244 s.

7. Mitsenko G.I. Osnovy metodiki sol'nogo peniya. M.: MGUKI, 2006. $30 \mathrm{~s}$.

8. Morozov V.P. Iskusstvo rezonansnogo peniya. M.: Iskusstvo, 2002. $256 \mathrm{s.}$

9. Pavlova M.A. Lektsii po metodike obucheniya sol'nomu peniyu. M.: Mosk. gos. otkr.un-t im. M.A. Sholokhova, 2004. 87 s.

10. Pluzhnikov K.I. Mekhanika peniya. Printsipy postanovki golosa: ucheb. posobie. 2-e izd. SPb.: Lan' : Planeta muzyki, 2013. 96 s.

11. Pryanishnikov K.I. Sovety obuchayushchimsya peniyu: ucheb. posobie. 6-e izd. SPb.: Lan' : Planeta muzyki, 2013. $144 \mathrm{~s}$.

12. Rakhcheev N.V. Postanovka golosa i metodika obucheniya peniyu. Minsk, 1988. 145 s.

13. Reshetnikova T.V. Formirovanie vokal'nykh navykov na urokakh sol'nogo peniya // Traditsii i innovatsii v sovremennom kul'turno-obrazovatel'nom prostranstve: mater. IX Mezhdunar. nauch.-prakt. konf. M.: MGPU, 2019. 225 s.

14. Savel'eva Yu.V., Smelkova T.D. Osnovy obucheniya vokal'nomu iskusstvu. SPb.: Lan' : Planeta muzyki, 2014. $160 \mathrm{~s}$.

15. Smelkova T.D. Osnovy obucheniya vokal'nomu iskusstvu. SPb.: Kompozitor, 2014. $154 \mathrm{s.}$

16. Sonki S.M. Teoriya postanovki golosa v svyazi s fiziologiej organov, vosproizvodyashchikh zvuk. M.: Librokom, 2014. 248 s.

17. Stakheeva M.V. Vokal'naya podgotovka inostrannykh obuchayushchikhsya (k voprosu mezhdunarodnogo sotrudnichestva Khabarovskogo gosudarstvennogo instituta kul'tury) // Voprosy razvitiya tvorcheskoj sredy Dal'nego Vostoka Rossii i Aziatsko-Tikhookeanskogo regiona: mater. Mezhdunar. nauch.-prakt. konf., posvyashch. 50-letiyu KhGIK. Khabarovsk, 2018. S. 217-222.

18. Urbanovich G.I. Pevcheskij golos uchitelya muzyki // Muzykal'noe vospitanie v shkole: sb. st. M., 1997. S. 12-16. 
19. Edel'man Yu.B. Uroki peniya. M.: Torus Press, 2010. $176 \mathrm{~s}$.

20. Erbshtejn M.S. Kratkij kurs prakticheskikh urokov peniya. M.: Muzyka, 1989. $76 \mathrm{~s}$.

\section{Библиографическое описание статьи / Reference to article}

Ануфриева Н.И. Современные методы постановки голоса в процессе обучения педагоговмузыкантов // Ученые записки Российского государственного социального университета. T. 19. 2020. № 1 (154). C. 106-113. DOI: 10.17922/2071-5323-2020-19-1-106-113 (Библиографическое описание согласно российским стандартам).

Anufrieva N.I. Sovremennye metody postanovki golosa $v$ processe obucheniya pedagogovmuzykantov // Uchenye zapiski Rossijskogo gosudarstvennogo social'nogo universiteta. T. 19. 2020. № 1 (154). S. 106-113. DOI: 10.17922/2071-5323-2020-19-1-106-113 (Reference in Roman script).

Anufrieva, N.I. (2020) Modern Methods of Voice Statement in the Process of Teaching Teachers-Musicians, Scientific Notes of Russian State Social University. Vol. 19. No. 1 (154). P. 106-113. DOI: 10.17922/2071-5323-2020-19-1-106-113 (International bibliographic description). 


\section{М.В. Переверзева,}

д-р искусствоведения, доцент кафедры социологии и философии культуры,

Российский государственный социальный университет, Москва.

M.V. Pereverzeva,

doctor of art science, associate professor of the department of sociology and

philosophy of culture, Russian State Social University, Moscow.

E-mail: melissasea@mail.ru

\section{В.А. Овсянникова,}

канд. пед. наук, доцент кафедры искусств и художественного творчества,

Российский государственный социальный университет, Москва.

V.A. Ovsyannikova,

candidate of pedagogical sciences, associate professor of the department of arts

and artistic work, Russian State Social University, Moscow.

E-mail: ovsyannikova.va@gmail.com

\section{Формирование концертмейстерского мастерства пианиста в процессе работы с академическими певцами над камерными сочинениями: сотворчество и равноправие артистов}

Formation of Concert Skill of the Pianist in the Process of Working with Academic Singers on Chamber Works: Creation and Equality of Artists

Дата поступления

25.12.2019
Дата препринта

28.02.2020
Дата публикации

30.03.2020

Аннотация: несмотря на то, что профессия концертмейстера необычайно широко распространена, одновременно с этим прослеживается тенденция к умалению значимости пианиста в таком ансамбле, когда его деятельность воспринимается сугубо как аккомпаниаторская. Тем не менее профессия концертмейстера полифункциональна и включает в себя педагогический, исполнительский и организационный аспекты. Она требует не только обширных знаний в сфере своего искусства (как фортепианного, так и концертмейстерского), но и владения вокальной терминологией и понимания ее. Для того чтобы аккомпанировать певцу, пианисту нужно прочувствовать этот процесс на себе, знать тонкости вокальной фонетики, дыхания, интонирования, знать типы голосов, чтобы способствовать их сбережению. Укоренившееся мнение по недооценке деятельности концертмейстера в профессиональной образовательной среде и концертном исполнительстве заставляет исследовать процесс формирования, а главное - методические принципы развития концертмейстерского мастерства пианиста в процессе работы концертмейстера и студента-вокалиста над камерными сочинениями.

Annotation: despite the fact that the profession of concertmaster is unusually widespread, at the same time there is a tendency to detract from the importance of the pianist in such an ensemble, when his activities are perceived purely as accompaniment. However, the concertmaster profession is polyfunctional and includes educational, performance and organizational aspects. It requires not only extensive knowledge in the field of its art (both piano and concertmaster), but also possession of vocal terminology and understanding of it. In order to accompany the singer, the pianist needs to feel this process by himself, know the subtleties 
of vocal phonetics, breathing, intonation, know the types of voices to help save them. The entrenched opinion on underestimating the activities of the concertmaster in the professional educational environment and concert performance makes it necessary to explore the process of formation, and most importantly methodological principles of development of concertmaster skills of the pianist in the process of work of the concertmaster and student-vocalist on chamber works.

Ключевые слова: концертмейстер, мастерство, пианист, вокалист, интерпретация, камерная музыка.

Key words: concertmaster, skill, pianist, vocalist, interpretation, chamber music.

Введение. Человеческий голос - самый совершенный музыкальный инструмент, удивительно богатый по своей природе. При всей красоте звучания голоса самого по себе желание ощутить себя частью общей гармонии заставляет певцов искать взаимодействие в ансамбле. Именно поэтому союз певца и пианиста-концертмейстера представляет собой столь популярную форму межисполнительского диалога, где оба партнера равноправны [1]. Главной целью сотворческой деятельности певца и концертмейстера становится трансляция музыкального содержания. Соответственно, необходимо путем совместной работы, анализа, размышлений, творческих исканий открывать всё новые глубины исполняемой музыки. При этом ввиду разного уровня понимания и восприятия взгляды на интерпретацию у концертмейстера и солиста могут не совпадать, поэтому формирование ансамбля может вызвать определенные трудности.

Концертмейстер должен быть осведомлен в вопросах культуры в целом, знать содержание опер, биографические факты из жизни композиторов и исполнителей, знать историю, уметь читать на иностранных языках, быть способным привести множество примеров из смежных видов искусств (литературы, живописи, скульптуры) [2]. Большое значение здесь приобретает также психологический аспект концертмейстерства, так как работа со студентами подразумевает предупреждение конфликтов, недопущение непонимания и творческого равнодушия.

Методы и методология. Методами исследования послужили анализ источников, музыкальный анализ произведений, педагогическое наблюдение, прогнозирование и проектирование педагогического и творческого процессов. 0 различных аспектах ансамблевого исполнительства и искусства концертмейстера, а также о процессе сотворчества в музыкальной деятельности писали А.Д. Готлиб, А.А. Люблинский, Д.Д. Благой, Дж. Мур, Е.М. Шендерович, В.Н. Чачава и другие; проблемами анализа музыкальных произведений и теории музыкального содержания занимались музыковеды: Х. Риман, В.Ф. Одоевский, А.Н. Серов, Б.Л. Яворский, Г. Кречмар, Э. Курт, А. Лоренц, Б.В. Асафьев, Л.П. Казанцева, В.Н. Холопова, А. Швейцер, Л.А. Мазель, В.А. Цуккерман, А.Ю. Кудряшов и многие другие; проблемы, связанные с профессиональным обучением пианистов в учреждениях профессионального музыкального образования, освещены в трудах И. Гофмана, Г.М. Когана, Н.А. Крючкова, А.А. Люблинского, Г.Г. Нейгауза, А.А. Николаева, С.И. Савшинского, В.И. Сафонова, Е.М. Тимакина, В.Н. Чачавы, А.А. Шмидт-Шкловской и других. Особый интерес представляют глубокие исследования музыкально-творческого процесса концертмейстерства Куприной Е.Ю. [8], Люблинского А.А. [9], Меркина Б.Г. и Меркина Г.С. [10], Мосина И.Э. [11], Островской Е.А. [13].

Результаты. Работа концертмейстера состоит из множества этапов и большого количества разнообразных задач вне зависимости от кажущейся простоты или сложности произведения. Нет простой музыки, так как за каждым произведением стоит своя личная история, и этот процесс постижения смысла и воплощение его в исполнении - задача, не имеющая ничего общего с прочтением нот. Для этого существует дисциплина сольфеджио, однако многие студенты, а подчас и преподаватели, считают вполне достаточным лишь красивое пение нот.

При знакомстве с новым произведением (которое может быть новым и для концертмейстера) концертмейстер играет нотный материал, всю трехстрочную партитуру, на ходу упрощая фактуру, чтобы дать понятие студенту о движении его мелодии и общей гармонии. 
Попутно необходимо дать объяснение по поводу формы (двух-, трехчастная, куплетная, простая, сложная и т.д.) с целью облегчить запоминание и выучку материала. Это важно при больших объемах текста, которые могут составить первое пугающее впечатление для вокалиста, впоследствии оказывающееся обманчивым ввиду повторения материала, репризности. Кроме того, концертмейстер должен обратить внимание студента на потенциально сложные места (интонационного, ритмического характера) и при необходимости показать, как работать в этих музыкальных фрагментах $[15 ; 18]$. Чтению с листа как одной из основополагающих компетенций концертмейстера уделял большое внимание М.А. Смирнов, открывая ценность так называемому целостному восприятию произведения [3].

Прежде чем приступать к самому нотному тексту, необходимо выполнить предварительную работу. Прежде всего, это относится к выявлению истории создания произведения. Необходимо изучить биографию композитора, поэта, соответствующую эпоху, год написания, при каких обстоятельствах было написано произведение (как у композитора, так и у поэта), кому посвящено. Важно учесть, целиком ли стихотворение воплотилось в музыке, так как зачастую композиторы используют лишь часть стихотворения, но этого недостаточно для воссоздания истории. Далее необходимо изучить тональность и ее семантику, отклонения и модуляции. Много содержания заложено в самом аккомпанементе, а именно: жанровая основа, размер, характер, штрихи, фактура изложения. Каждое указание должно быть подвергнуто анализу, каждый термин и указание - переведены. Если имеется вступление или заключение - значит, начало у концертмейстера, поэтому важно приучить певца к тому, что не всегда начинает он как солист, а что существует общее движение и взаимодействие ансамбля.

Требуется большое мастерство концертмейстера в подаче материала, чтобы в нем были настроение, характер, нужные акценты, энергия ритма и пульса, чтобы певец подхватил, «вытащил» свою мелодию из аккомпанемента, общей гармонии, а не искал способы, как начать. К тому же певец должен воспитывать себя не отсчитывать нужное количество тактов до своего вступления, что уже имеет отношение не к творчеству, а к математике, а знать досконально аккомпанемент, петь его мелодию и продолжить уже собственным голосом. Если дан один романс композитора, необходимо изучить все остальные, кратким обзором охватить их содержание, стилистику, жанровую палитру [20]. Если романс является частью цикла, то изучить, какое место по драматургии оно занимает в этом целом. Подобная аналитическая работа входит в область целостного анализа (В.А. Цуккерман, И.Я. Рыжкин и Л.А. Мазель).

Отдельная работа должна быть посвящена отработке текста. Текст должен быть выписан отдельно, потому что часто можно отметить неспособность студента прочитать грамотно стихотворение, так как происходит дублирование ритма самой мелодии. Часто чтение примитивно слоговое, однообразное, невыразительное и надуманное. Поэтому нужно при работе над текстом указать динамику, выделить главные слова, обратить внимание на паузы, которые должны звучать и оставаться в дыхании. Русская интонация подвержена динамическому затуханию в конце, что часто выражается и при разговоре, и при пении, что делает невозможным развитие фразы. Полезным будет изучить труды К.С. Станиславского, С.М. Волконского («Выразительное слово»), что касается техники речи. Надо сказать, что студенты часто не знают значения даже русских, незнакомых им слов, поэтому, чтобы не делать исполнение бессмысленным набором слогов, необходимо знать каждое слово, тогда будет лучше работать сила воображения [3].

Поскольку инструмент певца очень хрупкий, а произведения часто охватывают края диапазона, что для развивающегося голоса может привести к форсировке, концертмейстер должен уметь мгновенно транспонировать нотный материал для учебной работы и иметь несколько вариантов работы в тональностях с певцом. Вопросу транспонирования посвящена целая глава труда Н.А. Крючкова «Искусство аккомпанемента как предмет обучения» [6].

Когда физическое состояние певца не позволяет ему полноценно работать физически и эмоционально, можно прибегнуть к мелодекламационной форме работы. Следует отметить, 
что мелодекламация как жанр нашла отражение в творчестве Р. Шумана (2 баллады для чтеца с фортепиано), Ф. Шуберта («Прощание с Землей»), Ф. Листа («Ленора»), А. Аренского (стихотворения в прозе И.С. Тургенева). Это хорошая тренировка для слуха, ритмического чувства, выразительности речи, ее динамики, когда вокалист должен в аккомпанементе искать отражение своего текста и наговаривать свой текст звонко и наполненно, с динамическими оттенками и балансом. В музыке это делает говорящая, живая интонация, интервалика, тесситура, поэтому при мелодекламации необходимо помнить жизнь интонации и ее напряжение. 0 важной роли звукового баланса и профессиональном становлении концертмейстера писал выдающийся английский пианист Джеральд Мур [12].

Певец должен не только воспроизводить мелодию голосом, но и уметь ее играть на фортепиано с простым аккомпанементом, так как характер прикосновения будет точно такой же, принципы игры на всех инструментах схожи. Важно со стороны слышать, как движется мелодия. Это поможет петь сольфеджио, когда пальцы помнят каждую высоту, интервал, длительность. Для пробуждения исполнительских ощущений необходимо проникнуться атмосферой романсов, имеющих специфический окрас, например для жанра восточного романса, который так часто можно встретить в творчестве Н.А. Римского-Корсакова. Чтобы не исполнять такие произведения «по-русски», что уже будет стилистически неверно, нужно прочувствовать восточный менталитет, характер словоизложения, их красочные метафоры и эпитеты, темп речи, образную сферу, их культуру.

Концертмейстер должен идеально знать вокальную партию, при необходимости уметь показать голосом поставленные задачи, так как часто мы воспринимаем легче на слух и со стороны. Помогает утрированный показ, когда неточности доведены до степени абсурда, и тогда легче их исправить. Концертмейстер должен постоянно совершенствовать свои знания в области вокальной литературы и техники, чтобы помогать вокалисту в развитии и сохранении голосового аппарата. Большое внимание вопросу о вокальной фонетике, вокальной терминологии, а также бесценные методические рекомендации дает Важа Чачава в учебном пособии «Искусство концертмейстера» [14].

В совместной работе особенное внимание хотелось бы уделить системе К.С. Станиславского, принципы которой существуют не только для актеров, но и для художника в целом. Недаром сам автор системы говорил: «Пойте мысль!» [14, с. 14]. Выделим основные моменты, созвучные для работы концертмейстера и вокалиста.

1. Сценическое искусство и сценическое ремесло (необходимо уходить от годами выработанных штампов, искать новое, свое воплощение, иначе механика заменяет живую человеческую природу, и это уже чужое исполнение, в котором будет один и тот же вариант).

2. Магические понятия «если бы» и «предлагаемые обстоятельства», которые начинают творчество, давая толчок для дальнейшего развития роли. Отвечая бесконечно на эти вопросы «а если бы...», можно углубиться в образ и сделать его более цельным. Важное место здесь занимает подтекст, когда под отдельным словом или фразой скрывается своя жизнь, предыстория и история, конкретная эмоция.

3. Наличие круга внимания (малый, средний, большой), который помогает сценической работе, особенно при публичных выступлениях, когда необходимо чувствовать зрителя, но концентрация внимания остается на своей работе, игнорируются посторонние раздражители. Слух обращен на внутреннюю жизнь и на выращивание своих чувств.

4. Освобождение мышц, что особенно актуально у вокалиста, так как любое напряжение сказывается на качествах голоса. Безусловно, это относится также и к пианисту, и любому другому музыканту. Поэтому важно приучить себя следить за движением каждой мышцы, уметь расслаблять ее или иметь хорошее напряжение и контролировать свое тело.

5. Одновременное разделение произведения на более мелкие фрагменты, так как в каждом содержится своя творческая задача, но есть еще так называемая сверхзадача - основная мысль, зерно, из которого рождается произведение и ради которого оно создано. 
6. Правда и вера. Это ключевые понятия для любого искусства, так как невозможно делать то, чему не веришь, к тому же называть это творчеством. Искусство не терпит фальши и лжи, поэтому, чтобы сформировались естественные стереотипы, необходимо дать работу не мозгу, а физическому телу. Это заставит почувствовать естественность и успокоит разум, следовательно, важно не петь, а физически работать всем инструментом.

Обсуждение. Работа над техническими моментами исполнения происходит параллельно с совместным обнаружением и раскрытием смыслового аспекта музыки, где немаловажным фактором является создание концертмейстером благоприятной рабочей атмосферы; большое значение приобретает психологический настрой перед каждым концертным показом, а также само выступление на сцене, когда концертмейстер является незаменимой поддержкой и опорой; в целом психолого-педагогическая компетентность концертмейстера напрямую влияет на успешность и качество работы при обращении к камерному репертуару [16; 17].

На современном этапе развития музыкального образования и искусства исполнительства, изобилующем примерами юных виртуозов, играющих «взрослую» программу и демонстрирующих всю техническую оснащенность, хочется услышать саму музыку, которая призвана очищать нашу душу в обращении к Богу и раз за разом заставлять нас задуматься и переосмыслить жизнь [19]. Поэтому воспитание вдумчивого музыканта, интерпретатора, мыслителя, артиста является одной из важнейших задач профессионального образования. Воспитание вокалиста - задача вдвойне сложная, так как многие студенты начинают постигать азы музыкального искусства лишь в стенах вуза. Слабая музыкально-теоретическая подготовка и отсутствие опыта постижения смысла исполняемых произведений заставляют педагогов и концертмейстеров искать решения этого вопроса.

Концертмейстер в современном образовательном процессе не только выступает в роли аккомпаниатора, но и выполняет организаторские и педагогические функции. Первоначальная работа над произведением происходит именно с концертмейстером, который обязан организовать совместную работу так, чтобы она была увлекательной, познавательной и мотивировала студента. Поэтому необходим именно сотворческий подход к работе, диалог музыкантов, в совместном поиске которых рождаются варианты историй исполняемых произведений. Необходимо именно творчество, а не менторский подход, копирование и насаждение какого-либо варианта, что убивает искусство и провоцирует леность мысли. В этом сотворческом процессе углубляется работа студента в познании самого себя, ведь, чтобы быть способным исполнить многогранный вокальный репертуар, нужно обладать эмоциональным, слушательским опытом и вокальным интеллектом. Поэтому чем раньше начнется так называемая герменевтическая (музыкально-аналитическая) деятельность, тем результативнее будет происходить профессиональное становление будущего певца-вокалиста [16].

В свою очередь концертмейстер должен неустанно совершенствовать свои профессиональные навыки, знакомиться с репертуаром, анализировать музыку, расширять кругозор, чтобы суметь заинтересовать студента и погрузить его в мир музыки, речь которой можно и нужно правильно понимать, чтобы суметь ответить на любой заданный вопрос и иметь заслуженный авторитет. Совместная работа над программой на начальных этапах складывается с преобладающей инициативой и ведущей ролью концертмейстера. Однако надо стремиться к тому, чтобы в дальнейшем это общение становилось равноценным, чтобы студент приучался сам задавать себе вопросы, ставить задачи и решать их. На педагоге, концертмейстере лежит огромная ответственность за тот путь, который изберет в дальнейшем их подопечный, даже если его деятельность не будет связана с музыкой.

При сотворческой работе, не исключающей противоречий и столкновения мнений, концертмейстер должен понимать темперамент студента и иметь индивидуальный подход к каждому учащемуся. Важно понимать, что зачастую невнимательность и неспособность запомнить возникает не от нежелания работать, а ввиду холерического типа личности и ее не- 
собранности. Более медлительные флегматики часто избирают более медленные темпы при исполнении, бывают однообразны и неспособны импровизировать, поэтому концертмейстер должен находить приемы взаимодействия и активизации такого студента, особенно если он сам флегматик. Атмосфера должна быть рабочая и требовательная, но не исключающая юмора. Нельзя проходить мимо любого недочета, так как он укоренится и войдет в привычку, а это тоже говорит о равнодушии концертмейстера. Только любовь, доверие и желание познать всю красоту музыки может иметь право предъявлять требования. Психологическому аспекту в творчестве посвятили свои труды Л.С. Выготский, Л.А. Галин, Я.А. Пономарев и другие.

После всей подготовительной и репетиционной работы наступает самая волнительная и важная часть - концертное исполнение, несколько минут, ради которых музыкант трудится много часов, месяцев и лет. Немаловажным фактором становится умение создать контакт со зрительской аудиторией, как пишут 0.Я. Коробова, Д.И. Варламов [5] и Е.И. Кубанцева [7]. На сцене нужно быть темпераментным и выразительным, и это чувство тоже нужно тренировать, а не ждать благоприятного момента, веря, что стоит выйти на сцену - и всё само собой произойдет. «Сила страсти - это сдерживание страсти» [14, с. 16], то есть не форсирование звука, переходящего попросту в крик, преувеличенная динамика, театральные жесты, а концентрация на внутренних ощущениях, контроль за развитием чувств и их постепенным открытием, это работа на себя и от себя, а не на зрителя, потому что этот процесс очень личный и исповедальный. Концертное выступление как ничто другое позволяет проанализировать сделанную работу и наметить будущие задачи.

Выводы. Таким образом, музыкально-исполнительскую деятельность певца и концертмейстера можно рассматривать как сотворческий процесс на разных уровнях - с самим автором (композитором), со своим творческим «Я», с другими исполнителями, с педагогом, со слушателями. Камерная музыка как специфическая разновидность музыкального искусства отличается от музыки театральной, симфонической и концертной. С самого начала термин «камерная музыка» употреблялся в разных значениях: как произведения, предназначавшиеся для исполнения небольшими составами в небольших помещениях (от итал. camera - комната, палата); как светское музицирование; в классическом виде и составе инструментального / вокального ансамбля, когда композиторы видели своей задачей воплощение во всем богатстве особенностей каждого инструмента (голоса), формирование которого происходило постепенно [4, с. 229-230].

Становление концертмейстерства как самостоятельной профессии сложилось через практику аккомпанирования (а также импровизации) и ведения педагогической работы с исполнителями. Профессия концертмейстера является одной из наиболее востребованных и сложных, но вместе с тем труд концертмейстера остается недооцененным. Полифункциональная деятельность концертмейстера совмещает в себе деятельность педагогическую, организационную, исполнительскую, но не меньшее значение занимает уровень психологической компетентности. Обладание комплексом профессиональных качеств (хорошее чтение с листа, умение транспонировать нотный текст, хорошее чувство ансамбля и т.д.) должно сочетаться с высоким уровнем культуры, компетентности в разных областях музыкознания.

Таким образом, исполнительское сотворчество концертмейстера и студентов вузов культуры и искусства в классе сольного камерного и оперного исполнительства будет более успешным, если основой и целью этого сотрудничества станет совместное выявление содержания исполняемого произведения посредством его анализа.

\section{Список литературы}

1. Виноградов К.Л. 0 специфике творческих взаимоотношений пианиста-концертмейстера и певца // Музыкальное исполнительство и современность. Вып. 1. М.: Музыка, 1988. с. 151-178. 
2. Воронина Т.А. 0 камерном музицировании и становлении исполнителя // 0 мастерстве ансамблиста: сб. науч. тр. / отв. ред. Т. Воронина. Л.: Изд-во ЛоЛГК, 1986. С. 6-21.

3. Живов Л. Работа в концертмейстерском классе над пушкинскими романсами Глинки // 0 работе концертмейстера: сб. ст. / ред. М. Смирнов. М.: Музыка, 1974. С. 9-35.

4. Зимовина Л.А. Искусство камерного ансамбля (исполнительский и психолого-педагогический аспект) // Современные проблемы музыкальной педагогики высшей школы: межвуз. сб. науч. тр. Вып. 1 / науч. ред. И.Ю. Алиева. Тольятти: ТГУ, 2006. С. 315-338.

5. Коробова 0.Я., Варламов Д.И. Концертмейстер в современной музыкально-педагогической практике // Искусство и образование. 2010. № 3. С. 111-116.

6. Крючков Н.А. Искусство аккомпанемента как предмет обучения. Л.: Музгиз, 1961. 72 с.

7. Кубанцева Е.И. Концертмейстерский класс: учеб. пособие. М.: Академия, 2002. 192 с.

8. Куприна Е.Ю. Введение в сотворческую музыкально-исполнительскую деятельность: учеб. пособие для студентов музыкальных факультетов вузов. Тольятти, 2014. 242 с.

9. Люблинский А.А. Теория и практика аккомпанемента. Методические основы. Л.: Музыка, 1972. $81 \mathrm{C.}$

10. Меркин Б.Г., Меркин Г.С. Путь к сотворчеству. М.: Просвещение, 1991. 128 с.

11. Мосин И.Э. Творческая работа в концертмейстерском классе. СПб.: Лань : Планета музыки, 2018. 112 c.

12. Мур Дж. Певец и аккомпаниатор: Воспоминания: Размышления о музыке / пер. с англ. И.Г. Авалиани, И.В. Париной. М.: Радуга, 1987. 432 с.

13. Островская Е.А. Психологические аспекты деятельности концертмейстера в музыкально-образовательной сфере инструментального исполнительства: дис. ... канд. пед. наук. Тамбов, 2006. 233 с.

14. Парин А.В. Важа Чачава - артист и учитель. М.: Аграф, 2018. 320 с.

15. Переверзева М.В. Алеаторика как принцип композиции. СПб.: Планета музыки, 2018. $608 \mathrm{c.}$

16. Переверзева М.В., Казакова И.С. Профильная направленность дисциплин и ее значение в формировании ключевых компетенций специалистов в сфере культуры и искусств // Ученые записки Российского государственного социального университета. Т. 18. 2019. № 1 (50). С. 92-99.

17. Раабен Л.Н. Камерная музыка // Музыкальный энциклопедический словарь / гл. ред. Г.В. Келдыш. М.: Советская энциклопедия, 1991. С. 229-130.

18. Урываев С.А. Заметки о работе концертмейстера-пианиста в ДМШ // 0 мастерстве ансамблиста: сб. науч. тр. / отв. ред. Т. Воронина. Л.: Изд-во ЛОЛГК, 1986. С. 84-91.

19. Харлап М.Г. Исполнительское искусство как эстетическая проблема // Мастерство музыканта-исполнителя. Вып. 2. М.: Советский композитор, 1976. С. 5-68.

20. Холопова В.Н. Теории музыкального содержания, музыкальной герменевтики, музыкальной семантики: сходство и различия // Электронный журнал Общества теории музыки. 2013. № 4. URL: http://journal-otmroo.ru/sites/journalotmroo.ru/files/Kholopova\%20 V.N._2014_1.pdf (дата обращения: 19.12.2019).

\section{References}

1. Vinogradov K.L. 0 specifike tvorcheskikh vzaimootnoshenij pianista-koncertmejstera i pevca // Muzykal'noe ispolnitel'stvo i sovremennost'. Vyp. 1. M.: Muzyka, 1988. S. 151-178.

2. Voronina T.A. 0 kamernom muzicirovanii i stanovlenii ispolnitelya // 0 masterstve ansamblista: sb. nauch. tr. / otv. red. T. Voronina. L.: Izd-vo LOLGK, 1986. S. 6-21.

3. Zhivov L. Rabota $v$ koncertmejsterskom klasse nad pushkinskimi romansami Glinki // 0 rabote koncertmejstera: sb. st. / red. M. Smirnov. M.: Muzyka, 1974. S. 9-35.

4. Zimovina L.A. Iskusstvo kamernogo ansamblya (ispolnitel'skij i psikhologo-pedagogicheskij aspekt) // Sovremennye problemy muzykal'noj pedagogiki vysshej shkoly: mezhvuz. sb. nauch. tr. Vyp. 1 / nauch. red. I.Yu. Alieva. Tol'yatti: TGU, 2006. S. 315-338.

5. Korobova 0.Ya., Varlamov D.I. Koncertmejster v sovremennoj muzykal'no-pedagogicheskoj praktike // Iskusstvo i obrazovanie. 2010. № 3. S. 111-116.

6. Kryuchkov N.A. Iskusstvo akkompanementa kak predmet obucheniya. L.: Muzgiz, 1961. $72 \mathrm{~s}$.

7. Kubanceva E.I. Koncertmejsterskij klass: ucheb. posobie. M.: Akademiya, 2002. $192 \mathrm{s.}$

8. Kuprina E.Yu. Vvedenie v sotvorcheskuyu muzykal'no-ispolnitel'skuyu deyatel'nost': ucheb. posobie dlya studentov muzykal'nykh fakul'tetov vuzov. Tol'yatti, 2014. $242 \mathrm{~s}$.

9. Lyublinskij A.A. Teoriya i praktika akkompanementa. Metodicheskie osnovy. L.: Muzyka, 1972. $81 \mathrm{~s}$. 
10. Merkin B.G., Merkin G.S. Put' k sotvorchestvu. M.: Prosveshchenie, 1991. $128 \mathrm{~s}$.

11. Mosin I.E. Tvorcheskaya rabota v koncertmejsterskom klasse. SPb.: Lan': Planeta muzyki, 2018. $112 \mathrm{~s}$.

12. Mur Dzh. Pevec i akkompaniator: Vospominaniya: Razmyshleniya o muzyke / per. s angl. I.G. Avaliani, I.V. Parinoj. M.: Raduga, 1987. 432 s.

13. Ostrovskaya E.A. Psikhologicheskie aspekty deyatel'nosti koncertmejstera $v$ muzykal'noobrazovatel'noj sfere instrumental'nogo ispolnitel'stva: dis. ... kand. ped. nauk. Tambov, 2006. 233 s.

14. Parin A.V. Vazha Chachava - artist i uchitel'. M.: Agraf, 2018. 320 s.

15. Pereverzeva M.V. Aleatorika kak princip kompozicii. SPb.: Planeta muzyki, 2018. $608 \mathrm{s.}$

16. Pereverzeva M.V., Kazakova I.S. Profil'naya napravlennost' disciplin i eyo znachenie $\checkmark$ formirovanii klyuchevykh kompetencij specialistov $v$ sfere kul'tury $i$ iskusstv // Uchenye zapiski Rossijskogo gosudarstvennogo social'nogo universiteta. T. 18. 2019. № 1 (50). S. 9299.

17. Raaben L.N. Kamernaya muzyka // Muzykal'nyj enciklopedicheskij slovar' / gl. red. G.V. Keldysh. M.: Sovetskaya enciklopediya, 1991. S. 229-130.

18. Uryvaev S.A. Zametki o rabote koncertmejstera-pianista $v$ DMSh // 0 masterstve ansamblista: sb. nauch. tr. / otv. red. T. Voronina. L.: Izd-vo LOLGK, 1986. S. 84-91.

19. Kharlap M.G. Ispolnitel'skoe iskusstvo kak esteticheskaya problema // Masterstvo muzykantaispolnitelya. Vyp. 2. M.: Sovetskij kompozitor, 1976. S. 5-68.

20. Kholopova V.N. Teorii muzykal'nogo soderzhaniya, muzykal'noj germenevtiki, muzykal'noj semantiki: skhodstvo i razlichiya // Elektronnyj zhurnal Obshchestva teorii muzyki. 2013. № 4. URL: http://journal-otmroo.ru/sites/journalotmroo.ru/files/Kholopova\%20V.N._2014_1. pdf (data obrashcheniya: 19.12.2019).

\section{Библиографическое описание статьи / Reference to article}

Переверзева М.В., Овсянникова В.А. Формирование концертмейстерского мастерства пианиста в процессе работы с академическими певцами над камерными сочинениями: сотворчество и равноправие артистов // Ученые записки Российского государственного социального университета. Т. 19. 2020. № 1 (154). C. 114-121. DOI: 10.17922/2071-53232020-19-1-114-121 (Библиографическое описание согласно российским стандартам). Pereverzeva M.V., Ovsyannikova V.A. Formirovanie koncertmejsterskogo masterstva pianista $\checkmark$ processe raboty s akademicheskimi pevcami nad kamernymi sochineniyami: sotvorchestvo i ravnopravie artistov // Uchenye zapiski Rossijskogo gosudarstvennogo social'nogo universiteta. T. 19. 2020. № 1 (154). S. 114-121. DOI: 10.17922/2071-5323-2020-19-1-114121 (Reference in Roman script).

Pereverzeva, M.V. \& Ovsyannikova, V.A. (2020) Formation of Concert Skill of the Pianist in the Process of Working with Academic Singers on Chamber Works: Creation and Equality of Artists, Scientific Notes of Russian State Social University. Vol. 19. No. 1 (154). P. 114-121. D0I: 10.17922/2071-5323-2020-19-1-114-121 (International bibliographic description). 


\section{Е.Ю. Иванова,}

канд. культурологии, доцент кафедры искусств и художественного творчества,

Российский государственный социальный университет, Москва.

E.Yu. Ivanova,

candidate of cultural studies, associate professor of the department of arts

and artistic work, Russian State Social University, Moscow.

E-mail: catherine.iva@mail.ru

\section{Д.А. Бережной,}

канд. пед. наук, доцент кафедры искусств и художественного творчества,

Российский государственный социальный университет, Москва.

D.A. Berezhnoy,

candidate of pedagogical sciences, associate professor of the department of arts

and artistic work, Russian State Social University, Moscow.

E-mail:vnebo1@yandex.ru

\section{Образная сфера советской эстрадной песни середины XX века как отражение социокультурных ценностей советского общества}

\section{The Figurative Sphere of the Soviet Variety Song of the Mid-20 $0^{\text {th }}$ Century As a Reflection of the Sociocultural Values of Soviet Society}

\section{Дата поступления}

27.12.2019
Дата препринта

28.02.2020

\section{Дата публикации}

30.03.2020

Аннотация: в статье обращается внимание на то, что проблема воплощения художественного образа эстрадной песни вокалистами-исполнителями представляется сложной в силу необходимости раскрытия самых сокровенных порывов души, чувств и настроений человека, заложенных в поэтическом тексте и музыке. Далеко не все начинающие эстрадные певцы способны органично свести воедино все выразительные средства песни в совокупности фонетических, лексических, интонационных, гармонических средств поэтической и музыкальной выразительности. Весь перечисленный арсенал художественных приемов представлен в советской эстрадной песне середины XX века, в образной сфере которой нашли отражение социокультурные ценности советского общества того времени. Этим ценностям посвящено данное исследование.

Annotation: the article draws attention to the fact that the problem of implementing the artistic image of the variety song by vocalist-performers seems difficult due to the need to reveal the most cherished impulses of the soul, feelings and sentiments of the person, embedded in poetry text and music. Far from all beginner variety singers are able to organically bring together all expressive means of song in a combination of phonetic, lexical, intonation, harmonic means of poetic and musical expressiveness. All the listed arsenal of artistic techniques is presented in the Soviet variety song of the mid-20th century, in the figurative sphere of which the sociocultural values of Soviet society of the time were reflected. This study focuses on these values.

Ключевые слова: эстрада, массовая песня, советская музыка, образная сфера, социокультурные ценности, советское общество.

Key words: variety, mass song, Soviet music, imagine sphere, sociocultural values, Soviet society.

Введение. Возникшие в конце XIX века и стремительно множившиеся в предреволюционные годы всевозможные «подмостки», «открытые сцены», концертные эстрады, варьете, 
кабаре и др., представлявшие так называемый легкий жанр, к началу 1920-х годов в целях обеспечения государственного руководства были объединены в нашей стране термином «эстрада». В предвоенные годы большое развитие получила советская песенная эстрада. В этот период эстрада оформилась в отдельный вид искусства, который был наполнен репертуаром из небольших по объему концертных номеров, исполнявшихся одним певцом или группой артистов разных жанров.

Особое место на эстраде занимает песня. В предвоенные годы на эстраду выходили певцы с легко запоминающимися мелодиями песни и поэтическими текстами. Активно шел процесс творческого переосмысления фольклорного материала, хорошо известных бытовых музыкальных жанров. Уже до войны звуковое кино стало активным пропагандистом различных жанров музыкального творчества. Сошедшие в массы песни из кинофильмов обрели новую жизнь, превращаясь со временем в самостоятельные песни - символы целых поколений. Наряду с песнями-гимнами, маршами, появляются оборонные песни как ответ на тревожное предвоенное время. В этот жанр были заложены традиции военных песен, которые активно создавали советские композиторы (А.В. Александров, В.П. Соловьев-Седой и др.).

Безусловно, советская музыкальная культура и песенная эстрада второй половины 30-х начала 60-х годов XX века преемственно тесно связана с традициями прошлого [см. об этом: $1 ; 6 ; 7 ; 9 ; 14]$. Вместе с тем всё музыкальное пространство буквально дышало новыми идеями, которые были направлены на преобразование культуры своей страны и построение нового общества: в ней превалировали эстетические принципы социалистического реализма. На советскую песенную эстраду, равно как и на всё музыкальное искусство СССР, была возложена миссия активно формировать основу духовной жизни общества, идейные убеждения человека, его нравственные качества, эстетический вкус, воспитать правильного гражданина социалистической формации.

В предисловии сборника документов «Власть и художественная интеллигенция» отмечается, что «с первых своих шагов государство диктатуры пролетариата предложило интеллектуальной элите страны свободу лишь в пределах, не мешавших реализации коммунистической программы и не стеснявших его действия. Образ мышления власти, ее политическая практика и основные институты по регулированию взаимоотношений с творческой интеллигенцией в основном сформировались в течение первого десятилетия после Октябрьской революции. Уже тогда власть продемонстрировала, что она понимает под духовной свободой личности, каким она представляет себе человека нового революционного общества» [2, с. 6].

Вместе с тем, несмотря на гонения, репрессии в отношении многих деятелей и учреждений культуры, идеологический диктат, музыкальное искусство в многонациональной стране развивалось, эстрадные жанры совершенствовались, для исполнителей создавался новый репертуар, в том числе не всегда политически «окрашенный», а репрезентирующий общечеловеческие ценности, которые не были забыты в советской социокультурной политике.

Методика. Методологической базой исследования послужили работы, посвященные:

- процессу формирования творческой личности в контексте социально-исторических изменений в обществе (труды Б.Д. Грекова, А.П. Каджана, В.В. Кусковой, Б.А. Рыбакова, Р.Г. Скрынникова и др.);

- культурологическим проблемам музыкального искусства, раскрытым в исследованиях А.А. Баранцева, Ю.Е. Бойко, А.В. Денисова, И.А. Корсаковой, Г.И. Панкевич, А.И. Щербаковой и др.;

- проблеме психологии искусства (публикации Л.С. Выготского, В.Н. Дружинина, Г.В. Иванченко, О.А. Кривцун, В.В. Медушевского, Ю.А. Цагарелли, Г.М. Цыпина и др.);

- теоретическим и эстетическим аспектам содержания произведений эстрадного искусства, исследованным Н.Н. Аниным, И.М. Брилем, Г.Г. Вороновым, Е.Н. Дивовым, В.Д. Конен, В.Г. Кузнецовым, Е.М. Кузнецовым, С.П. Луниным, Ю.С. Саульским, О.Н. Тюриной, Ю.Н. Чугуновым и др. 
При анализе советской песенной эстрады второй половины 30-х - начала 60-х годов XX века использовался достаточно широкий круг источников: к данной проблематике обращались М.А. Бурматов, Д.А. Журкова, О.С. Ильичева, Л.М. Кадцын, В.П. Конев, Ю.С. Корев, В.В. Лелеко, Е.Л. Рыбакова, Н.И. Смирнова, А.Н. Сохор и др.

Методами исследования послужили: изучение, отбор, анализ источников, филологический, текстологический и музыкальный анализ текстов и мелодий песен советского периода, но главное - переосмысление наследия советского песенного искусства и его переоценка с позиций современности.

Результаты. Д.А. Журкова точно формулирует предназначение песни, которое можно отнести к сценическому искусству эстрады: «...песня как ни один другой музыкальный жанр умеет мгновенно схватывать и запечатлевать в истории дух времени, оставаться в памяти своеобразным сколком того или иного периода, "вытягивающим" за собой все остальные его приметы» [3, с. 123].

Музыка, массовая песня стали составной частью общественных событий и мероприятий. По окончании военных действий и с переходом страны к мирному существованию общества все жанры массовой культуры начали обновляться очень стремительно. В 20-х и первой половине 30-х годов XX века происходило переосмысление всего музыкального мира, деятельности всех культурно-досуговых учреждений и организаций. Один за другим появлялись любительские организации, коллективы, кружки самодеятельности, клубы. В активную фазу вошли различные формы проведения массовых праздников, смотров самодеятельного искусства при участии огромного количества людей.

С середины 20-х годов прошлого века начали регулярно выходить в радиоэфир передачи, которые способствовали приобщению огромного числа населения страны к музыкальному искусству. В этот же период на новой волне развивалось самодеятельное творчество, особенно песенное. В это время создается большой песенный репертуар, который становится достоянием рабочих и крестьян, например «Наш паровоз, вперед лети», «Там, вдали за рекой, зажигались огни». Значительному обновлению подвергались театральные и концертные программы, которые включали в себя вновь созданные произведения композиторов и театральных деятелей.

Отметим, что советское музыкальное творчество к середине 30-х годов XX века уже накопило ценный опыт в ряде эстрадных жанров отечественной музыкальной культуры. Популярность той или песни стремительно возрастала благодаря появлению в мульт- или кинофильме. Главными темами как кинофильмов, так и песен были «одобренные» руководством и идеологией темы: труд, патриотизм, - а также широкий круг лирических тем и образов. Особенную популярность приобрели молодежные песни-гимны: «Молодежная» из кинофильма «Волга, Волга», «Спортивный марш» из кинофильма «Вратарь», «Эх, хорошо» и «Марш энтузиастов», автором которых был И. Дунаевский [17, с. 51]. Кинофильм «Волга, Волга» стал своего рода энциклопедией советской массовой песни тех времен [20].

Безусловно, идеологическая патетика 1930-х годов влияла и отражалась на песенном репертуаре эстрадных певцов. Чаще всего с эстрадных подмостков исполнялись героические и патриотические песни. В этот период становления эстрадного искусства новый репертуар практически не создавался, но стоило лишь какой-либо песне прозвучать на радио, театральной сцене или в кинофильме, она тут же находила свое место на эстраде. Ее исполняли не только профессиональные певцы, но и простые слушатели. Именно поэтому эстрадные вокалисты практически выступали пропагандистами новых песен, в первую очередь лирических.

Звучавшие в эти годы песни в исполнении К. Шульженко, Л. Утёсова, Л. Руслановой, М. Бернеса и других отличались волнующим лиризмом интонаций, жизнерадостностью мироощущения, гуманистическим утверждением положительных начал жизни человека, что зачастую им ставилось в вину: некоторые песни из репертуара эстрадных исполнителей назывались вульгарными, мещанскими, идеологически вредными. 
В качестве примера приведем опубликованное 4 сентября 1946 года постановление 0ргбюро ЦК ВКП(б) «0 кинофильме “Большая жизнь"», в котором резко отрицательную оценку получили не только представленная картина восстановления Донбасса, но и введенные в фильм песни композитора Н. Богословского на слова А. Фатьянова, В. Агатова, проникнутые «кабацкой меланхолией и чуждые советским людям» [13].

В 30-е годы XX века продолжал свою деятельность открытый в 1923 году Московский Мюзик-холл, который Е.Л. Рыбакова называет пролетарским [15, с. 22]. В Московском Мюзик-холле с концертами выступали Л. Утёсов, Г. Амурский, И. Гурко, Г. Афонин, В. Милич, А Громова, К. Шульженко и др. Именно здесь в 1934 году появился знаменитый спектакль «Под куполом цирка», по материалу которого несколько позже режиссер Г. Александров снял фильм «Цирк». В 1937 году в Москве, Ленинграде закрываются мюзик-холлы и лишь спустя четверть века они будут открыты вновь.

В конце 30-х годов XX века театры эстрадных миниатюр открываются в Москве, Ленинграде и других областных центрах. Эстрадные концерты проводились в больших вместительных залах, дворцах культуры, театрах. Массовое посещение больших аудиторий залов, безусловно, повлияло на наполнение и популяризацию эстрадных программ. Лейтмотивом этого периода стала строчка «Нам песня строить и жить помогает...» из песни «Марша веселых ребят» И. Дунаевского.

В эти годы в домах советских граждан появились граммофоны, грампластинки и радиоприемники, с городских танцплощадок звучали джаз-бэнды. Несмотря на закрытость молодого советского государства, популярная среди советской молодежи музыка зачастую мало чем отличалась от зарубежной: «Балом в то время правил джаз. Причем были популярны не столько записи американских исполнителей, сколько творчество отечественных джазменов, в первую очередь стоит назвать неподражаемого Леонида Утёсова и его “Теа-Джаз" (“театрализованный джаз")» [4, с. 107].

В перечень популярных исполнителей и песен входили Л. Орлова с песней «Марш энтузиастов», Л. Утёсов - «Сердце, тебе не хочется покоя», «Марш веселых ребят», «Утомленное солнце», «Московских окон негасимый свет», А. Цфасман - «Неудачное свидание», Д. Шостакович - «Песня о встречном», П. Лещенко - «Песня о Родине», И. Дунаевский - «Песня о веселом ветре», «Спортивный марш», А. Варламов - «Уходит вечер», В. Козин - «Дружба» и др. [16].

Нами было проанализировано довольно большое количество источников, которые дали возможность сделать вывод о том, что всемерный подъем эстрадного исполнительского искусства способствовал проведению в 1939 году 1-го Всесоюзного конкурса артистов эстрады. Этот конкурс выявил целую когорту новых профессиональных исполнителей, позволил зрителям познакомиться с новыми жанрами сценического эстрадного искусства, а главное, наметить дальнейший вектор развития всех эстрадных стилей и жанров. По окончании конкурса правительством было принято решение по открытию новых концертных залов (например, в Москве на площади В. Маяковского).

Следующее постановление было направлено на необходимость оборудовать специальные залы для проведения эстрадных вечеров. К составлению концертных программ должны были быть привлечены композиторы, поэты, талантливые артисты. Но, пожалуй, самым примечательным событием стало решение проблемы профессиональной подготовки молодых кадров для эстрады. Эстрадные факультеты, отделения создавались в ГИТИСе, Московском хореографическом училище, Московском техникуме циркового искусства.

В 1940 году на базе Всесоюзной студии эстрадного искусства, которой руководил Н. Смирнов-Сокольский, был создан Художественный совет. В этот совет вошли самые крупные мастера эстрады. В этом же году была проведена Декада советской музыки и эстрады. Во время проведения этого мероприятия публика могла познакомиться с лучшими образцами эстрадного искусства. Дальнейшую реорганизацию и осуществление на практике мероприятий по оптимизации процесса развития эстрадного искусства прервала Великая 
Отечественная война, которая поставила перед артистами эстрады новые задачи. Буквально на второй день войны ЦК РАБИС ${ }^{1}$ выпустил обращение к работникам культуры и искусства, в котором артистов призывали встать рядом с бойцами.

Наряду с первыми эшелонами солдат на фронт выдвинулись бригады эстрадных исполнителей разных жанров. И на протяжении всех военных лет они прошли вместе с боевыми частями по всем дорогам войны. Участники фронтовых бригад выступали практически везде: в лесу, на полянах, в госпиталях, на оборонных предприятиях в тылу, перед работниками колхозов и совхозов. Концертные программы были составлены с учетом настроения слушателей. Присущие эстрадному искусству умение мобильно реагировать на происходящие события помогали артистам выйти на передний план борьбы за освобождение своей Родины. Огромное количество эстрадников были отмечены высокими государственными наградами.

Главной песней, которая задала направление песне 40-х годов, стала «Священная война» А. Александрова. Преобладающими темами в музыкальных произведениях стали любовь к Родине, готовность к самопожертвованию, мечты и воспоминания о мирной жизни; в песнях воспевался героизм советских солдат. Зачастую песни создавались композиторами очень быстро, согласно призыву «Песня - фронту»: поэты выбирали наиболее громкие и выразительные газетные заголовки, а композиторы сочиняли пронзительные и героические мелодии [4, с. 108].

Помимо героико-патриотических песен большой популярностью пользовались песни военного быта. В список «народных» песен вошли «Священная война», «Если завтра война», «Катюша», «Синий платочек», «Темная ночь», «Два Максима», «Давай закурим», «Моя Москва» и др. Лейтмотивом 50-х годов XX века стала строчка «Когда весна придет» из песни, прозвучавшей в кинофильме «Весна на Заречной улице». На заре периода послесталинской «оттепели» ведущими темами в популярной музыке стали труд, патриотизм, молодость.

0бсуждение. Чем ближе к 60-м годам XX века, тем больше популярная музыка становилась лиричной. Особое место в популярной музыке заняла субкультура «стиляг»: с середины столетия на российских эстрадных исполнителей всё больше влияют западные певцы, особенное впечатление оставляет творчество американцев Гленна Миллера, Бенни Гудмана, Дюка Эллингтона [11], позже - выступления Элвиса Пресли, Чака Берри, Литтла Ричарда, рок-н-ролл и другие стили западной музыки от кантри до соула [10].

В перечень популярных исполнителей и песен входили М. Бернес «Враги сожгли родную хату», Н. Рыбников «Когда весна придет», «Марш монтажников-высотников», Л. Гурченко «Пять минут», Г. Отс «Одинокая гармонь», 3. Рождественская «На катке», В. Трошин «Подмосковные вечера», Р. Атакишиев «Я встретил девушку», И. Алексеев «Ты только одна виновата», П. Рудаков «Мишка» и др.

Лейтмотивом 60-х годов XX века стала «Песня о тревожной молодости». Это десятилетие исследователи отмечают обращением «к внутреннему миру человека» [12, с. 189], теме молодости, энергии, космоса, мира, всего человечества. Труд, юность, оптимизм, смелые дерзания советского гражданина, уверенность в будущем отражаются в образной сфере песен А. Пахмутовой («Орлята учатся летать», «Надо мечтать», «Главное, ребята, сердцем не стареть»), Петрова - Шпаликова («Я шагаю по Москве»), Фельцмана - Войновича («Я верю, друзья»), Мурадели - Долматовского («И на Марсе будут яблони цвести»), Блантера - Дыховичного - Слободского («Присядем, друзья, перед дальней дорогой») [5, с. 13].

Исследователь В. Марочкин подчеркивает, что в 60-е годы и позднее официальные власти, руководствуясь идеологическими установками, положили в основу работы с населением именно массовую песню, содержание которой несло в себе формирование духовно-нравственного облика советского человека. Однако то огромное воздействие, которое начала оказывать на массовую публику лирическая песня, не нашедшая себе равных на советской эстраде во второй половине XX века, свидетельствовало о значимости новых социокультурных ценностей для советского общества позднего периода [8, с. 219].

${ }^{1}$ Центральный комитет профессионального союза работников искусств. 
Заключение. Исследователь Т.В. Чередниченко по поводу образной сферы и эстетики массовой советской песни отмечала, что советская эстрада взвалила на себя идеологический груз, выступая при этом в роли «массовика-затейника» [18]. Такое двойственное положение не мешало эстрадному искусству СССР рождать всё новые поистине подлинные музыкальные шедевры. Таким образом, советская песенная эстрада на протяжении 30-60-х годов XX века активно развивалась, появлялись новые звезды, новые жанры, формировался новый круг тем и образов [19].

Каждое десятилетие в развитии отечественной песенной эстрады характеризуется своими достижениями, неповторимым колоритом: его нельзя видеть лишь в черно-белых красках. Молодые эстрадные исполнители делали первые шаги на сцене, только начинали свою карьеру, пробовали себя в новых жанрах и формах искусства. И большим достижением советских исполнителей стало создание богатой палитры эпических и лирических образов, не связанных с советской идеологией, но отражающих социокультурные ценности советского общества, несущих в себе идею формирования высоконравственного облика советского человека - доброго, благородного, глубоко чувствующего и понимающего происходящее вокруг, полного оптимизма и жизнерадостности, с богатым внутренним миром, которым он готов делиться с окружающими.

\section{Список литературы}

1. Булавка Л.А. Феномен советской культуры: монография. М.: Культурная революция, 2008. $288 \mathrm{c}$.

2. Власть и художественная интеллигенция. Документы ЦК РКП (б) - ВКП (б), ВЧК - ОГПУ НКВД о культурной политике. 1917-1953 / сост. А.Н. Артизов, О.В. Наумов; под ред. А.Н. Яковлева. М.: Междунар. фонд «Демократия», 1999. 872 с.

3. Журкова Д.А. Что показывает песня? Популярная музыка на советском телевидении. Ч. 1. 1960-1970-е гг. // Обсерватория культуры. 2015. № 3. С. 122-134.

4. Кадцын Л.М. Массовое музыкальное искусство XX столетия. Эстрада, джаз, барды и рок в их взаимосвязи. Екатеринбург: РГППУ, 2006. 424 с.

5. Квасникова Л.А. Дорогами песен Александры Пахмутовой: рассказы о музыке. М.: Музыка, 1979. 59 c.

6. Конев В.П. Советская художественная культура периода 30-80-х годов XX века: теоретико-исторический анализ: дис. ... д-ра искусствоведения. Кемерово, 2004. 415 с.

7. Лелеко В.В. Мифопоэтический образ Родины в советской песне 1940-1980-х годов // Вестник Санкт-Петербургского государственного университета культуры и искусств. 2013. № 4 (17). C. 112-116.

8. Марочкин В., Сычева Н., Игнатьев А. Песни нашего поколения. Шестидесятые: хроника событий, интервью. Ростов н/Д: Феникс, 2010. 223 с.

9. Михайловская А.Г. Российская авторская (бардовская) песня: историко-этнологическое исследование: дис. ... канд. ист. наук. М., 2006. 368 с.

10. Переверзева М.В. Музыка США: в поисках национального стиля // США и Канада: Экономика. Политика. Культура. 2019. № 49 (8). С. 107-122.

11. Переверзева М.В. Традиционная музыка США: историческая и жанровая панорама // Музыкальная академия. 2017. № 2. С. 89-95.

12. Попова Т.В. 0 песнях наших дней. М.: Музыка, 1969. 490 с.

13. Постановление Оргбюро ЦК ВКП (б) от 4 сентября 1946 г. «0 кинофильме “Большая жизнь"» // Литературная газета. 1946. 14 сент.

14. Русская советская эстрада, 1946-1977: очерки истории. М.: Искусство, 1981. 526 с.

15. Рыбакова Е.Л. Развитие музыкального искусства эстрады в художественной культуре России: автореф. дис. ... д-ра культурологии. М., 2007. 43 с.

16. Скороходов Г.А. Звезды советской эстрады: очерки об эстрадных певцах, исполнявших советские лирические песни. 2-е изд., испр. и доп. М.: Советский композитор, 1986. 184 с.

17. Сохор А.Н. Путь советской песни. М.: Советский композитор, 1968. 108 с.

18. Чередниченко Т.В. Эра пустяков, или Как мы, наконец, пришли к легкой музыке и куда, возможно, пойдем дальше // Новый мир. 1992. № 10. С. 222-231.

19. Эстрада сегодня и вчера. 0 некоторых эстрадных жанрах конца XX-XXI века / ред. 0.А. Кузнецова. М.: Гос. ин-т искусствознания, 2010. 304 с. 
20. Kupfer P. Volga-Volga: «The story of a song», vernacular modernism, and the realization of soviet music // Journal of Musicology. 2013. No. 30 (4). P. 530-576.

\section{References}

1. Bulavka L.A. Fenomen sovetskoj kul'tury: monografiya. M.: Kul'turnaya revolyuciya, 2008. $288 \mathrm{~s}$.

2. Vlast' i khudozhestvennaya intelligenciya. Dokumenty CK RKP (b) - VKP (b), VChK OGPU - NKVD o kul'turnoj politike. 1917-1953 / sost. A.N. Artizov, 0.V. Naumov; pod red. A.N. Yakovleva. M.: Mezhdunar. fond «Demokratiya», 1999. $872 \mathrm{~s}$.

3. Zhurkova D.A. CHto pokazyvaet pesnya? Populyarnaya muzyka na sovetskom televidenii. Ch. 1. 1960-1970-e gg. // Observatoriya kul'tury. 2015. № 3. S. 122-134.

4. Kadcyn L.M. Massovoe muzykal'noe iskusstvo XX stoletiya. Estrada, dzhaz, bardy i rok v ikh vzaimosvyazi. Ekaterinburg: RGPPU, 2006. $424 \mathrm{~s}$.

5. Kvasnikova L.A. Dorogami pesen Aleksandry Pakhmutovoj: rasskazy o muzyke. M.: Muzyka, 1979. $59 \mathrm{~s}$.

6. Konev V.P. Sovetskaya khudozhestvennaya kul'tura perioda 30-80-kh godov XX veka: teoretiko-istoricheskij analiz: dis. ... d-ra iskusstvovedeniya. Kemerovo, 2004. $415 \mathrm{~s}$.

7. Leleko V.V. Mifopoeticheskij obraz Rodiny v sovetskoj pesne 1940-1980-kh godov // Vestnik Sankt-Peterburgskogo gosudarstvennogo universiteta kul'tury i iskusstv. 2013. № 4 (17). S. 112-116.

8. Marochkin V., Sycheva N., Ignat'ev A. Pesni nashego pokoleniya. Shestidesyatye: khronika sobytij, interv'yu. Rostov n/D: Feniks, 2010. 223 s.

9. Mikhajlovskaya A.G. Rossijskaya avtorskaya (bardovskaya) pesnya: istoriko-etnologicheskoe issledovanie: dis. ... kand. ist. nauk. M., 2006. $368 \mathrm{s.}$

10. Pereverzeva M.V. Muzyka SShA: v poiskakh nacional'nogo stilya // SShA i Kanada: Ekonomika. Politika. Kul'tura. 2019. № 49 (8). S. 107-122.

11. Pereverzeva M.V. Tradicionnaya muzyka SShA: istoricheskaya i zhanrovaya panorama // Muzykal'naya akademiya. 2017. № 2. S. 89-95.

12. Popova T.V. 0 pesnyakh nashikh dnej. M.: Muzyka, 1969. $490 \mathrm{~s}$.

13. Postanovlenie Orgbyuro CK VKP (b) ot 4 sentyabrya 1946 g. «0 kinofil'me “Bol'shaya zhizn"'»// Literaturnaya gazeta. 1946. 14 sent.

14. Russkaya sovetskaya estrada, 1946-1977: ocherki istorii. M.: Iskusstvo, 1981. $526 \mathrm{~s}$.

15. Rybakova E.L. Razvitie muzykal'nogo iskusstva estrady v khudozhestvennoj kul'ture Rossii: avtoref. dis. ... d-ra kul'turologii. M., 2007. 43 s.

16. Skorokhodov G.A. Zvezdy sovetskoj estrady: ocherki ob estradnykh pevcakh, ispolnyavshikh sovetskie liricheskie pesni. 2-e izd., ispr. i dop. M.: Sovetskij kompozitor, 1986. $184 \mathrm{~s}$.

17. Sokhor A.N. Put' sovetskoj pesni. M.: Sovetskij kompozitor, 1968. $108 \mathrm{~s}$.

18. Cherednichenko T.V. Era pustyakov, ili Kak my, nakonec, prishli k legkoj muzyke i kuda, vozmozhno, pojdem dal'she // Novyj mir. 1992. № 10. S. 222-231.

19. Estrada segodnya i vchera. 0 nekotorykh estradnykh zhanrakh konca XX-XXI veka / red. 0.A. Kuznecova. M.: Gos. in-t iskusstvoznaniya, 2010. $304 \mathrm{~s}$.

20. Kupfer P. Volga-Volga: «The story of a song», vernacular modernism, and the realization of soviet music // Journal of Musicology. 2013. No. 30 (4). P. 530-576.

\section{Библиографическое описание статьи / Reference to article}

Иванова Е.Ю., Бережной Д.А. Образная сфера советской эстрадной песни середины XX века как отражение социокультурных ценностей советского общества // Ученые записки Российского государственного социального университета. Т. 19. 2020. № 1 (154). C. 122-128. DOI: 10.17922/2071-5323-2020-19-1-122-128 (Библиографическое описание согласно российским стандартам).

Ivanova E.Yu., Berezhnoj D.A. Obraznaya sfera sovetskoj estradnoj pesni serediny XX veka kak otrazhenie sociokul'turnykh cennostej sovetskogo obshchestva // Uchenye zapiski Rossijskogo gosudarstvennogo social'nogo universiteta. T. 19. 2020. № 1 (154). S. 122-128. DOI: 10.17922/2071-5323-2020-19-1-122-128 (Reference in Roman script).

Ivanova, E.Yu. \& Berezhnoy, D.A. (2020) The Figurative Sphere of the Soviet Variety Song of the Mid-20 $0^{\text {th }}$ Century As a Reflection of the Sociocultural Values of Soviet Society, Scientific Notes of Russian State Social University. Vol. 19. No. 1 (154). P. 122-128. D0I: 10.17922/20715323-2020-19-1-122-128 (International bibliographic description). 


\title{
Н.И. Ануфриева,
}

д-р пед. наук, профессор, заведующая кафедрой социологии и философии культуры, директор Высшей школы музыки им. А. Шнитке (институт),

Российский государственный социальный университет, Москва.

N.I. Anufrieva,

doctor of pedagogical sciences, professor, head of the department of sociology and philosophy of culture, director Higher school of music n.a. A. Schnittke (institute), Russian State Social University, Moscow.

E-mail: nata415485@mail.ru

\section{Е.Б. Покивайлова,}

старший преподаватель кафедры искусств и художественного

творчества, Высшая школа музыки им. А. Шнитке (институт),

Российский государственный социальный университет, Москва.

E.B. Pokivaylova,

senior lecturer of the department of arts and artistic work, Higher school

of music n.a. A. Schnittke (institute), Russian State Social University, Moscow.

E-mail: poklen@yandex.ru

\section{Педагогический потенциал музыкальных произведений для детей композиторов XX века}

\author{
Pedagogical Potential of Musical Works for Children \\ of the $X X^{\text {th }}$ Century Composers
}

Дата поступления

19.12.2019
Дата препринта

28.02.2020
Дата публикации

30.03.2020

Аннотация: обращение к теме детской музыки и образов детства в музыкальном искусстве открывает широкие горизонты для исследования, как в области музыкознания и культурологии, так и в области музыкальной педагогики и методики, так как обучение музыке с детства не только обеспечивает всестороннее развитие личности ребенка, но и создает основу для его профессионального музыкально-исполнительского будущего. В статье анализируются музыкальные произведения для детей композиторов XX века, обладающие большим, но пока не раскрытым в науке и на практике развивающим, воспитательным и образовательным потенциалом, благодаря которому формируются музыкальный и эстетический вкус, музыкально-исполнительские навыки, развиваются музыкальные способности и расширяется слуховой опыт.

Annotation: an appeal to the subject of children's music and images of childhood in musical art opens up wide levels for research both in the field of musicology and cultural studies, as well as in the field of musical pedagogy and methodology, as learning music from childhood provides not only comprehensive development of the child's personality, but also creates the basis for his professional musical and performing future. The article analyzes musical works for children of composers of the 20th century, possessing large but not yet revealed in science and in practice developing, educational and educational potential, thanks to which musical and aesthetic taste, musical and performing skills are formed, musical abilities are developed and hearing experience is expanded.

Ключевые слова: музыкальная педагогика, искусство, музыка для детей, циклы для детей, композиторы ХХ века, методика обучения. 
Key words: music pedagogy, art, music for children, cycles for children, $X X^{\text {th }}$ century composers, teaching methods.

Введение. Мир детства и юношества, запечатленный в произведениях одного из самых «детских» композиторов С.С. Прокофьева, - это одна из важнейших граней его творческого облика. Прокофьева выделяет стремление, как можно раньше приобщить ребенка к высокому искусству. В ряду особенностей музыки Прокофьева о детях важную роль заняло его мастерство в раскрытии восприятия внешнего и внутреннего мира ребенка. Как педагог Прокофьев поставил перед собой задачу - способствовать росту личности ребенка и его приобщению к культуре. Еще сильнее эта тенденция проступает в сюжетах на реалистической основе. Так, в вокально-симфонической фреске «Баллада о мальчике, оставшемся неизвестным», которая написана на стихи П. Антокольского, в изображении героя, пережившего личную трагедию, Прокофьевым использованы средства драматизации.

Свое первое сочинение для детей Прокофьев создал в одном из самых любимых им жанров - цикле фортепианных миниатюр. Так появился сборник из 12 пьес - «Детская музыка» ор. 65. Без сомнения, образцом для Прокофьева послужили шумановский «Альбом для юношества» и «Детский альбом» Чайковского. Однако в своем цикле композитор не только следует романтической традиции, но и незаметно спорит с ней.

В «Детской музыке» Прокофьев старается избегать романтического психологизма. Здесь нет пьес, подобных «Болезни куклы» из «Детского альбома» Чайковского или «Зиме» Шумана. Пожалуй, лишь «Раскаяние», имевшее первоначальное название «Стыдно стало», может служить примером психологического монолога «от первого лица». Остальные миниатюры это «взгляд со стороны», хотя и детский. «Детская музыка» интересна тем, что кажется, будто она написана не о ребенке, не для ребенка, а ребенком. Композитор стремился к полной «детскости».

Прокофьев, работая над детским циклом, ограничил круг тем. Его интересовала та реальность, та сторона жизни, с которой дети сталкиваются повседневно. Этим и объясняется отсутствие необычных персонажей, экзотических зарисовок. Сборник занимателен тем, что дети имеют возможность «узнать» себя в искусстве. Прокофьев смотрит на мир глазами ребенка, входит в этот мир, в жизнь ребенка. Это становится очевидным при сравнении «Детского альбома» Чайковского и «Детской музыки». Оба цикла имеют схожую сюжетную основу: это день ребенка. У Чайковского - зимний день, у Прокофьева - летний день, день на воздухе.

Методы и методология. Основными методами исследования музыки для детей с точки зрения ее педагогического потенциала служат методы музыкознания: анализ текста, интертекстуальный анализ, компаративистский подход, метод ассоциаций. Применим также метод обобщения педагогического опыта и прогнозирования результатов педагогической практики на основе результатов анализа музыкальных текстов. Методологической базой исследования послужили работы музыковедов-историков $[1 ; 2 ; 4 ; 6 ; 7 ; 9-11 ; 15 ; 16]$, учебные и методические труды [3; 5], специальные исследования, посвященные специфике музыки для детей [12; 14], музыки XX века [16-20] и психологии музыкального восприятия и творчества [13].

Результаты. Рассмотрим ряд пьес, в которых композиторы воплощают одни и те же ситуации, однако по-разному смотрят на них. «Зимнее утро» - второй номер сборника Чайковского, и «Утро», открывающее «Детскую музыку» Прокофьева. Трепетная пьеса Чайковского воплощает поэзию детства, чувство приятного волнения перед неизведанным, чувство, которое приносят первые лучи солнца в детскую комнату. Чайковский как бы сам вспоминает сладостные моменты своей жизни. У Прокофьева это не воспоминания, а реальность: знакомый пейзаж, утренняя роса, дыхание ребенка.

Фантастические образы в сборнике Чайковского воплощены в пьесе «Нянина сказка». Сказку эту рассказывает взрослый: сложные гармонии, причудливый ритм, динамика, яркие 
контрасты. У Прокофьева же «Сказочка» - это затаенная, безыскусная пьеса с неуверенной поступью аккомпанемента, незамысловатыми параллелизмами. Это «Сказочка» ребенка, его продукт творчества.

Сравним «Марш деревянных солдатиков» П.И. Чайковского с «Маршем» С.С. Прокофьева. В своей пьесе Чайковский воплощает излюбленную им стихию кукольности, марш же Прокофьева лишен этой стихии: использование басовых регистров, разнообразные штрихи, динамика, ритмика не столь статична. Это марш детей, а не кукол. Сам жанр, безусловно, провоцирует композитора на использование «кукольной стихии». Однако Прокофьев обращается к реальному миру.

В двух заключительных номерах - «Вечер» и «Ходит месяц над лугами» - композитор пошел по пути Чайковского, который воссоздал народные обороты в «Детском альбоме», не прибегая к цитированию, в отличие от композиторов А.К. Лядова и Б. Бартока, положивших в основу фольклорный материал. В этих миниатюрах Прокофьев передает аромат природы, воссоздает тишину летних вечеров в маленьких русских городах. Пьесы были написаны в Поленове на Оке. Эта музыка, рожденная средней Россией, впоследствии будет использована композитором в уральском балете «Сказ о каменном цветке» (пьеса «Вечер» станет характеристикой героини балета Катерины, а во втором акте в качестве танца самоцветов войдет в «Вальс»). Затрагивая тему «переклички» пьес из «Детской музыки» со «взрослой», нелишним будет отметить, что отзвуки лирической второй части «Четвертой симфонии» слышатся в музыке первых двух пьес цикла - «Утра» и «Прогулки». И, конечно же, «Марш» и «Вальс» по-своему характеру тесно связаны со многими страницами театральной и симфонической музыки Прокофьева.

Цикл «Детская музыка» является переломным произведением в области фортепианного творчества для Прокофьева. Композитор вновь обращается к родному музыкальному языку, с нежностью воспроизводит народные обороты. Национальной определенностью проникается «сонатинный стиль». Впервые этот стиль соединяется с программностью. Упоминая о своей «старой любви к сонатинности», Прокофьев подразумевает особую ясность изложения музыкальных мыслей, относительную простоту музыки и, как правило, прозрачность фортепианной фактуры.

Средства выразительности не подвергаются Прокофьевым пересмотру. Они, наоборот, наиболее подходят для выражения наивных образных представлений детей. Тончайшими средствами - с помощью двухголосия, еле заметных альтераций - рисует композитор картины природы, передает тончайшие нюансы настроений. Перекрестное положение рук, параллельное ведение голосов приобретает у Прокофьева новый смысл, становится средством изобразительности. Сонатинный стиль наполнился эмоциональностью, русским мелодизмом.

В новом качестве предстает в «Детской музыке» и прокофьевский миниатюризм. Это не те миниатюры парижского периода, в мир которых композитор ушел от того, что у него «не хватало дыхания» ни на что другое в области фортепианной музыки (недаром даже произведения крупной формы - Пятый концерт - составлен фактически из миниатюр). Это небольшие новеллетты, звуковые пейзажи с тонким показом «сюжетиков» природы. В «Детской музыке» преобладает стихия движения, жестов и пластики. Прокофьев умело делает зримое слышимым. К этой группе пьес относятся «Прогулка», «Тарантелла», «Вальс», «Шествие кузнечика», «Пятнашки», «Марш». Например, прерывистая, прихотливая мелодия «Вальса», напоминающая и о балете «Золушка», и о вальсе Наташи из оперы «Война и мир», и о многих других вальсовых эпизодах прокофьевской музыки. А вот знаменитый «Марш»собранный, «строгий», без тени стилизации, насыщенный «прокофьевскими» гармониями. Но и тут мелькает добрая улыбка композитора. Уж слишком «Марш» серьезный и даже «надутый».

Стихия моторики, физического движения предстает и по-иному. «Тарантелла» и «Пятнашки» - самые быстрые пьесы цикла. Они даже немного похожи - в основном благодаря 
непрерывному движению терций. Но если в «Тарантелле» танец захватывает всех, то в «Пятнашках» мы видим, как бегают дети, стараясь догнать друг друга. И даже «Шествие кузнечиков» - это веселый, несколько «угловатый» гопак. Все эти пьесы можно легко представить в качестве небольших балетных номеров. Они отличаются выразительной, рельефной мелодикой, четким ритмическим рисунком, ясными и вместе с тем не такими уж простыми гармониями.

В пейзажных зарисовках «Утро», «Дождь и радуга», «Вечер» и «Ходит месяц над лугами» Прокофьев почти не идет по пути импрессионистской звукописи. Исключение - миниатюра «Дождь и радуга», в которой падающие капли дождя передаются с помощью аккордов, составленных из секунд, повторений звуков. Создается ощущение огромного пространства между небом и землей, деревьями и облаками.

Все пьесы имеют программные названия и разнообразные сюжетные линии, различаются по характеру музыки, увлекательны своими образами, занимательны необычной мелодикой, гармонией и ритмом. Все эти качества можно обнаружить уже в первой пьесе - «Утро», открывающей цикл. Собственно, это начало дня. Солнце еще не взошло, но его первые лучики мягко освещают природу. В глубоких басах слышны отголоски уходящей ночи. Эту пьесу достаточно часто исполняют учащиеся музыкальных школ. В третьем номере цикла Прокофьев вводит нас в излюбленную им область сказочности. Эта трогательная, тихая, нежная и очень русская по мелодике, напоминающей русский жалеечный наигрыш, «Сказочка» принадлежит к лучшим пьесам сборника.

Следующий номер - чудесный, светлый, пленяющий своей гибкой, пластичной мелодикой, «Вальс» является характерным танцем для всего творчества Сергея Прокофьева. «Шествие кузнечиков» - забавное скерцо с маршевым характером, где большую часть занимают энергичные фанфарные интонации. Упругий, отскакивающий ритм точно передает движение этих прыгающих созданий. Пьеса «Дождь и радуга» начинается с «капель дождя», но это не буквальное изображение явления природы, а поэтичное музыкальное отображение реальной картины (что свойственно импрессионистскому стилю). Широкая напевная мелодия невольно ассоциируется с радугой.

«Марш» - очередная пьеса цикла. Это достаточно популярное произведение, которое часто исполняется и любимо детьми. Решительному и энергичному характеру произведения способствуют многие фактурные особенности пьесы. «Ходит месяц над лугами» - последняя пьеса цикла - по своему характеру эта пьеса близка русским лирическим и хороводным песням. Но, тем не менее, и здесь нет цитирования народного мелоса. Если «Вечер» перекликается, образует образную арку с «Утром», то музыка пьесы «Ходит месяц над лугами» близка начальной пьесе «Сказочка». Пьеса характеризуется нежным, тонким, поэтичным настроением.

«Детская музыка» теперь прочно утвердилась в педагогическом репертуаре. Она любима и достаточно часто исполняется детьми. Однако музыкальный язык произведений Прокофьева для детей нельзя назвать примитивным или упрощенным. Композитор не собирается жертвовать ни одной из особенностей своего стиля. Ее включают в свой репертуар и сложившиеся исполнители.

Сборник Прокофьева «Детская музыка» необходимо рассматривать с точки зрения естественной эволюции детского фортепианного репертуара. Так, рассматривая детские сборники Шумана и Чайковского, можно найти такие технические приемы, которых не знала детская фортепианная литература на момент создания данных сборников. Это говорит о том, что фортепианный стиль каждого крупного композитора раздвигает сложившиеся представления о возможностях инструмента, мастерстве исполнения.

Немаловажным фактором для восприятия «Детской музыки» детьми и интерпретации является программность. Это специфическое качество музыкальной образности использовали и другие композиторы, писавшие для детской аудитории. Благодаря этой яркой образности, 
пластичному и рельефному тематизму «Детская музыка» нашла широкий круг как слушателей, так и исполнителей. Эта важная отличительная черта произведений Прокофьева для детей. Маленький пианист, играющий «Детскую музыку», участники театральной или хореографической постановки по «Пете и волку», детский хор в «Зимнем костре»- включение в репертуар этих произведений содействует сближению и постижению музыки Прокофьева.

Одним из решающих факторов принятия прокофьевской музыки детьми, без сомнения, является чуткость композитора к современным интонациям, отражение в музыке многообразной действительности. «Детская музыка» представляет собой пример широкого творческого диапазона Прокофьева. Она созвучна психологии детского восприятия мира, эмоциональному характеру богатого детского воображения, чуткого к сказочной фантастике, волнующей романтике, героике истории и современности. Это проявляется в жанровом разнообразии и широте интонаций. В данном цикле композитор по-новому претворяет русскую лирическую песню и темпераментную итальянскую тарантеллу, задорный марш.

Незаурядный талант, непоколебимая любовь к музыке и вера в целительную силу искусства - вот что ставит Бенджамина Бриттена в один ряд с бессмертными гениями, творения которых по праву считаются шедеврами. Британский композитор, чьи первые шаги в музыке и обучении композиции сопоставимы со стараниями юного Моцарта, сумел завоевать признание при жизни и стать одним из самых заметных и выдающихся классиков современности.

B XX веке композиторы стали намеренно писать музыку, понятную детям, - такие сочинения, как правило, должны иметь название, содержать понятные детям образы, быть звукоизобразительными, небольшими, в простых формах, с яркими гармониями и запоминающимися мелодиями. Бриттен широко известен как музыкант-просветитель. 0н создал много музыки для детей и юношества. Самым известным произведением в жанре музыки для детей стали «Вариации и фуга на тему Перселла», которые написаны как «Путеводитель по оркестру для юных слушателей».

Это произведение композитор создал в 1945 году. В отличие от Прокофьева он не основывал его на сказочном сюжете, в котором каждому инструменту была бы поручена роль какого-либо персонажа, да в этом и не было необходимости, ведь изначально музыка писалась для документального фильма «Инструменты оркестра», созданного британским дирижером Джеймсом Мэтисоном. В качестве «действующих лиц» выступают музыкальные инструменты как таковые, но это вовсе не делает сочинение скучным или малопонятным, ведь композитор адресовал его детям. Собственных сыновей или дочерей у Бриттена не было, но детей он любил и прекрасно понимал - об этом свидетельствуют такие его сочинения, как сборник песен «После полудня в пятницу», опера «Давайте создадим оперу!», «Ноев ковчег» на основе средневекового миракля, водевиль «Золотая тщета» - это не просто произведения для детского восприятия: дети участвуют в их исполнении, «изнутри» познавая искусство. И даже в тех произведениях Бриттена, которые предназначены для взрослых, присутствуют партии, рассчитанные на детские голоса, - таковы оперы «Сон в летнюю ночь», «Поворот винта».

На партитуре «Путеводителя по оркестру» начертано посвящение: «Это произведение с нежностью посвящается детям Джона и Джейн Моуд - Хемфри, Памеле, Каролине и Вирджинии - в целях образовательных и для развлечения».

«Путеводитель» Бриттена знакомит детей не только с музыкальными инструментами в каждой из вариаций представлен тот или иной жанр. Например, в соло кларнета есть нечто от балетной музыки, в вариации скрипок - ритм полонеза, у трубы - марш, у валторны ноктюрн и т.д. Обращаясь к детям, Бриттен следует «золотому правилу»: говорить доступно, но не примитивно, не упрощать искусственно. Композитор не боится представлять юным слушателям такую сложную полифоническую форму, как фуга, - она завершает цикл вариаций: к этому времени слушатели уже познакомились с разными инструментами, и им проще будет различить их тембры в причудливом переплетении голосов. Фуга основана на теме, 
созданной самим Бриттеном, но в нее вплетается и тема Пёрселла - и это можно интерпретировать как символическую «связь времен».

Обсуждение. Бенджамин Бриттен создал еще одно значимое произведением для детей - оперу «Ноев ковчег», которая может стать подспорьем для педагогов-организаторов и просветителей. Это произведение развивает вечную тему, которая как никогда остро стоит перед современными людьми: проблема сохранения жизни человечества. Сюжет, положенный в основу оперы «Ноев ковчег», известен широко - речь идет о библейской истории о Всемирном потопе, который Бог обрушивает на погрязшее во грехе человечество. Только праведник Ной и его близкие, построившие по велению Господа ковчег, спасаются вместе с животными, чтобы заново дать начало жизни на обновленной Земле. Впрочем, сюжет композитором был позаимствован не непосредственно из библейской книги Бытия, а из его средневековой обработки.

В Средние века, в том числе и в Англии, сюжеты из жизни святых или из Священного писания нередко представлялись в театрализованном виде. Назывались такие представления мираклями (от лат. miraclium - «чудо»). Наиболее древние английские рукописи, сохранившие тексты мираклей, относятся к XVI веку. В одной из подобных рукописей, известной как Честерский цикл, содержится миракль о Всемирном потопе - вот на этот текст и опирался Бенджамин Бриттен, создавая оперу. Как и во всех английских мираклях, библейские персонажи изображаются здесь как живые люди, близкие и понятные современникам. Так, сам Ной мало чем отличается от обычного английского горожанина XVI века, вынужденного терпеть сварливую жену - она откровенно насмехается над его планами строительства ковчега, в то время как сыновья Ноя помогают ему. В то же время Ной выглядит опытным корабельщиком - он со знанием дела прилаживает бушприт, грот-мачту и снасти, чтобы «поднять паруса с отливом». К честерскому мираклю о Ноевом потопе обращался не только Бриттен, но и другой выдающийся композитор XX века - Игорь Федорович Стравинский.

Не только участие сверстников в спектакле способно увлечь детей при просмотре оперы «Ноев ковчег». Композитор включает в партитуру множество остроумных звуковых приемов. Наряду с эффектными, но все-таки традиционными ударными инструментами, такими как литавры или колокольчики, здесь можно услышать такие необычные «музыкальные инструменты», как чашки, подвешенные на веревке, или наждачная бумага. В опере очень удачно сочетаются моменты разной природы - и драматические, и комедийные. Впрочем, занимательность этого произведения не заслоняет собою главной его идеи - глубокой веры и почтения к Богу.

Мировая премьера оперы «Ноев ковчег» состоялась 18 июля 1958 года в городе 0pфорд, расположенном в графстве Саффолк, на Альдебургском фестивале. Но произошло это не в оперном театре, а в церкви - таково было желание композитора. Следуя замыслу Бриттена, оперу долгое время ставили только в церквях, а также в залах духовных училищ, и лишь десятилетия спустя ее стали исполнять в театрах. В 1964 году в Англии она была поставлена на телевидении и на радио. Самая масштабная постановка произведения осуществилась в 2004 году - в ней участвовало 300 детей.

Заключение. $K$ теме детства и всему, что с ним связано, обращались многие мастера рубежа XIX-XX столетий. Особенно активизировалось сочинение детской музыки в XX веке. Западноевропейскую линию музыки для детей представляют сочинения Б. Бартока, К. Орфа, П. Хиндемита, Б. Бриттена, отечественную - сочинения С.С. Прокофьева, Д.Д. Шостаковича, А.И. Хачатуряна, Д.Б. Кабалевского и многих других композиторов. Как показал анализ произведений, педагогический потенциал этих опусов для детей невероятно высок и не исчерпан в музыкально-педагогической практике.

Проанализированные музыкальные произведения для детей композиторов XX века обладают большим, но пока не раскрытым в науке и на практике развивающим, воспитательным и образовательным потенциалом. Благодаря изучению и освоению этих произведений у де- 
тей формируются музыкальный и эстетический вкус, музыкально-исполнительские навыки, развиваются музыкальные способности и расширяется слуховой опыт. Поэтому на данный момент необходимо активнее вводить детские циклы композиторов XX века в педагогическую и социокультурную практику. Вместе с тем необходимы пересмотр содержательной части программ обучения детей музыке в общеобразовательных и музыкальных школах, а также совершенствование методик обучения детей музыке XX века.

\section{Список литературы}

1. Аверьянова 0. Русская музыка второй половины XX века: книга для чтения по «Музыкальной литературе». М.: Росмэн, 2004. 139 с.

2. Басманова Т., Уфимцева Е. Зарубежная музыка XX века в контексте ведущих течений художественной культуры: учебник-конспект для музыкальных колледжей и музыкальных училищ. Екатеринбург, 1998. 180 с.

3. Енукидзе Н. Популярные музыкальные жанры. Из истории джаза и мюзикла: книга для чтения по «Музыкальной литературе». М.: Росмэн, 2004. 125 с.

4. Житомирский Д., Леонтьева А., Мяло К. Западный музыкальный авангард после Второй мировой войны. М.: Музыка, 1989. 303 с.

5. Ильичева А., Иофис Б. Европейская музыка XX века: книга для чтения по «Музыкальной литературе». М.: Росмэн, 2004. 139 с.

6. История зарубежной музыки: учебник для музыкальных вузов. Вып. 6. / ред. В. Смирнов. СПб.: Композитор, 1999. 625 с.

7. История зарубежной музыки: учебник. Вып. 5 / ред. И. Нестьев. М.: Музыка, 1988. 448 с.

8. Казакова И.С., Переверзева М.В. Профильная направленность музыкальных дисциплин и ее значение в формировании ключевых компетенций специалистов в сфере культуры и искусства // Ученые записки Российского государственного социального университета. Т. 18. 2019. № 1 (150). С. 92-99.

9. Кандинский А. Русская музыкальная литература. Вып. 3 / А. Кандинский, 0. Аверьянова, Е. Орлова. М.: Музыка, 2014. 464 с.

10. Конен В.Д. Очерки по истории зарубежной музыки. М.: Музыка, 1997. 640 с.

11. Левая Т. Русская музыка начала XX века в художественном контексте эпохи. М.: Музыка, 1991. 166 с.

12. Лукина И.В. Образы и жанры детской музыки в 20 веке // AS-SOL.NET: образовательный портал для преподавателей ДМШ. URL: http://as-sol.net/publ/scenarii/obrazy_i_zhanry_ detskoj_muzyki_v_20_veke/4-1-0-432.

13. Назайкинский Е. 0 психологии музыкального восприятия. М., 1992. 383 с.

14. Немировская И.А. Феномен детства в творчестве отечественных композиторов второй половины XIX - первой половины XX века: автореф. дис. ... д-ра искусствоведения. Магнитогорск: Магнитогор. гос. консерватория, 2011. 48 с.

15. Нестьев И.В. Сергей Прокофьев. М.: Музыка, 2011. 713 с.

16. Сапонов М.А., Переверзева М.В., Акопян Л.О., Изотова Е.А., Комарницкая О.В., Максимчук М.В., Манулкина О.Б., Сигида С.Ю., Тушинцева И.А., Ухов Д.П., Ханина Л.Б., Цареградская Т.В. История современной музыки: музыкальная культура США XX века: учебник. Сер. 68: Профессиональное образование. 2-е изд. М.: Юрайт, 2019. 540 с.

17. Соколов А.С. Введение в музыкальную композицию XX века: учеб. пособие по курсу «Анализ музыкальных произведений» для студ. высш. учеб. завед. М., 2004. 231 с.

18. Стригина Е.В. Музыка XX века: учеб. пособие для студ. муз. училищ и вузов. Бийск: Бия, 2006. 280 c.

19. Энтелис Л. Силуэты композиторов XX века. Л.: Музыка, 1975. 248 с.

20. Davydova A.A., Lushnikov S.S., Pereverzeva M.V., Smirnov A.V., Tsarev D.V. Piano music of composers-minimalists in the teaching repertoire of higher music education // Opcion. 2018. No. 34 (Special Issue 17). P. 149-162.

\section{References}

1. Aver'yanova 0 . Russkaya muzyka vtoroj poloviny XX veka: kniga dlya chteniya po «Muzykal'noj literature». M.: Rosmen, 2004. 139 s.

2. Basmanova T., Ufimceva E. Zarubezhnaya muzyka XX veka $v$ kontekste vedushchikh techenij khudozhestvennoj kul'tury: uchebnik-konspekt dlya muzykal'nykh kolledzhej i muzykal'nykh uchilishch. Ekaterinburg, 1998. $180 \mathrm{~s}$. 
3. Enukidze N. Populyarnye muzykal'nye zhanry. Iz istorii dzhaza i myuzikla: kniga dlya chteniya po «Muzykal'noj literature». M.: Rosmen, 2004. $125 \mathrm{~s}$.

4. Zhitomirskij D., Leont'eva A., Myalo K. Zapadnyj muzykal'nyj avangard posle Vtoroj mirovoj vojny. M.: Muzyka, 1989. 303 s.

5. Il'icheva A., Iofis B. Evropejskaya muzyka XX veka: kniga dlya chteniya po «Muzykal'noj literature». M.: Rosmen, 2004. 139 s.

6. Istoriya zarubezhnoj muzyki: uchebnik dlya muzykal'nykh vuzov. Vyp. 6. / red. V. Smirnov. SPb.: Kompozitor, 1999. $625 \mathrm{~s}$.

7. Istoriya zarubezhnoj muzyki: uchebnik. Vyp. 5 / red. I. Nest'ev. M.: Muzyka, 1988. 448 s.

8. Kazakova I.S., Pereverzeva M.V. Profil'naya napravlennost' muzykal'nykh disciplin $\mathrm{i}$ ee znachenie $\mathrm{v}$ formirovanii klyuchevykh kompetencij specialistov $v$ sfere kul'tury $\mathrm{i}$ iskusstva // Uchenye zapiski Rossijskogo gosudarstvennogo social'nogo universiteta. T. 18. 2019. № 1 (150). S. 92-99.

9. Kandinskij A. Russkaya muzykal'naya literatura. Vyp. 3 / A. Kandinskij, 0. Aver'yanova, E. Orlova. M.: Muzyka, 2014. 464 s.

10. Konen V.D. Ocherki po istorii zarubezhnoj muzyki. M.: Muzyka, 1997. $640 \mathrm{s.}$

11. Levaya T. Russkaya muzyka nachala XX veka v khudozhestvennom kontekste epokhi. M.: Muzyka, 1991. $166 \mathrm{s.}$

12. Lukina I.V. Obrazy i zhanry detskoj muzyki v 20 veke // AS-SOL.NET: obrazovatel'nyj portal dlya prepodavatelej DMSh. URL: http://as-sol.net/publ/scenarii/obrazy_i_zhanry_detskoj_ muzyki_v_20_veke/4-1-0-432.

13. Nazajkinskij E. 0 psikhologii muzykal'nogo vospriyatiya. M., 1992. $383 \mathrm{~s}$.

14. Nemirovskaya I.A. Fenomen detstva $v$ tvorchestve otechestvennykh kompozitorov vtoroj poloviny XIX - pervoj poloviny XX veka: avtoref. dis. ... d-ra iskusstvovedeniya. Magnitogorsk: Magnitogor. gos. konservatoriya, 2011. $48 \mathrm{~s}$.

15. Nest'ev I.V. Sergej Prokof'ev. M.: Muzyka, 2011. $713 \mathrm{s.}$

16. Saponov M.A., Pereverzeva M.V., Akopyan L.0., Izotova E.A., Komarnickaya 0.V., Maksimchuk M.V., Manulkina O.B., Sigida S.Yu., Tushinceva I.A., Ukhov D.P., Khanina L.B., Caregradskaya T.V. Istoriya sovremennoj muzyki: muzykal'naya kul'tura SShA XX veka: uchebnik. Ser. 68: Professional'noe obrazovanie. 2-e izd. M.: Yurajt, 2019. 540 s.

17. Sokolov A.S. Vvedenie v muzykal'nuyu kompoziciyu XX veka: ucheb. posobie po kursu «Analiz muzykal'nykh proizvedenij» dlya stud. vyssh. ucheb. zaved. M., 2004. $231 \mathrm{s.}$

18. Strigina E.V. Muzyka XX veka: ucheb. posobie dlya stud. muz. uchilishch i vuzov. Bijsk: Biya, 2006. $280 \mathrm{~s}$.

19. Entelis L. Siluety kompozitorov XX veka. L.: Muzyka, 1975. 248 s.

20. Davydova A.A., Lushnikov S.S., Pereverzeva M.V., Smirnov A.V., Tsarev D.V. Piano music of composers-minimalists in the teaching repertoire of higher music education // Opcion. 2018. No. 34 (Special Issue 17). P. 149-162.

\section{Библиографическое описание статьи / Reference to article}

Ануфриева Н.И., Покивайлова Е.Б. Педагогический потенциал музыкальных произведений для детей композиторов XX века // Ученые записки Российского государственного социального университета. Т. 19. 2020. № 1 (154). C. 129-136. DOI: 10.17922/2071-53232020-19-1-129-136 (Библиографическое описание согласно российским стандартам). Anufrieva N.I., Pokivajlova E.B. Pedagogicheskij potencial muzykal'nykh proizvedenij dlya detej kompozitorov XX veka // Uchenye zapiski Rossijskogo gosudarstvennogo social'nogo universiteta. T. 19. 2020. № 1 (154). S. 129-136. D0I: 10.17922/2071-5323-2020-19-1-129136 (Reference in Roman script).

Anufrieva, N.I. \& Pokivaylova, E.B. (2020) Pedagogical Potential of Musical Works for Children of the XXth Century Composers, Scientific Notes of Russian State Social University. Vol. 19. No. 1 (154). P. 129-136. D0I: 10.17922/2071-5323-2020-19-1-129-136 (International bibliographic description). 


\title{
М.Г. Круглова,
}

канд. пед. наук, доцент кафедры социологии и философии культуры,

Российский государственный социальный университет, Москва.

M.G. Kruglova,

candidate of pedagogical sciences, associate professor of the department

of sociology and philosophy of culture, Russian State Social University, Moscow.

E-mail: marisha.krug@mail.ru

\section{Е.И. Григорьева,}

д-р культурологии, профессор кафедры искусств и художественного

творчества, Российского государственного социального университета, Москва.

E.I. Grigorieva,

doctor of cultural studies, professor of the department of arts and artistic work,

Russian State Social University, Moscow.

E-mail: grigorev_tmb@list.ru

\section{Особенности восприятия музыки детьми и их влияние на жанры детской музыки}

\author{
Features of Children's Perception of Music \\ and Their Impact on Children's Music Genres
}

$\begin{array}{ccc}\text { Дата поступления } & \text { Дата препринта } & \text { Дата публикации } \\ 17.12 .2019 & 28.02 .2020 & 30.03 .2020\end{array}$

Аннотация: традиции детской музыки складывались на протяжении XVIII-XIX веков, причем именно в XIX веке сформировался образ ребенка как личности. В XX веке искусство подарило детям множество превосходных сочинений, разных по своим художественно-эстетическим качествам и значимости для общего и музыкального развития ребенка. Однако исследований музыки для детей в творчестве русских и зарубежных композиторов XIX-XX века с точки зрения специфики, круга тем, образов и средств музыкальной выразительности до сих пор не так много, несмотря на высокую значимость данного музыкального жанра. Специфика, основные темы и образы, средства музыкальной выразительности в произведениях для детей композиторов России и зарубежья XIX-XX веков обусловлены особенностями восприятия музыки детьми, которым посвящена данная paбoma.

Annotation: traditions of children 's music developed throughout the XVIII-XIX centuries, and it was in the XIX century that the image of the child as a person was formed. In the XX century, art gave children many excellent works, different in their artistic and aesthetic qualities and importance for the general and musical development of the child. However, there are still not many studies of music for children in the work of Russian and foreign composers of the XIX-XX century in terms of specificity, circle of topics, images and means of musical expression, despite the high importance of this musical genre. Specifics, main themes and images, means of musical expression in works for children of composers of Russia and abroad of the XIX-XX centuries are due to peculiarities of perception of music by children to whom this work is devoted.

Ключевые слова: музыка, детское восприятие, жанры детской музыки, образ ребенка, музыкальное развитие, Шуман, Чайковский.

Key words: music, children's perception, children's music genres, child image, music development, Schumann, Tchaikovsky. 
Введение. Расширять слуховой опыт и формировать навык эмоционального и аналитического восприятия музыки важно с первого этапа музыкального развития детей. Умение понимать искусство звуков и интерпретировать содержание произведений у детей возникает в практической музыкальной деятельности. Музыкальное восприятие представляет собой процесс, задействующий физические и психические реакции человека на звуки, результатом которого становится эмоциональное переживание и осмысление музыкального содержания. Практическая музыкальная деятельность (слушание и исполнение произведений) активизирует музыкальное мышление, повышая уровень его развития и тем самым способствуя пониманию композиторского замысла на глубоком уровне.

Способности к осмысленному музыкальному восприятию проявляются у детей уже в раннем детстве, когда они обращают свое внимание на окружающий мир. При этом объекты познаются детьми сначала на эмоциональном уровне, и музыка этому способствует как никакое другое искусство. У младших школьников формируется наглядно-образное мышление, при этом продолжает играть важную роль эмоционально-чувственное восприятие действительности. Именно в детском возрасте характерна эмоциональная отзывчивость на непосредственные впечатления, поэтому так важно и необходимо музыкальное воспитание детей с раннего возраста $[14 ; 15]$.

Методика. Основой исследования послужил теоретический анализ искусствоведческой, музыковедческой и психолого-педагогической литературы. Использован также метод музыкально-теоретического и сравнительного анализа при разборе музыкальных произведений. Методологической основой для разработки проблемы данной работы послужили статья Б.В. Асафьева «Русская музыка о детях и для детей» (1948), а также работы отечественных и зарубежных музыковедов-теоретиков и историков. Кроме того, исследование специфики восприятия музыки детьми проводилось на основе трудов, посвященных проблемам:

- общей и возрастной психологии (В.С. Мухина, Л.С. Выготский);

- психологии восприятия и музыкальной деятельности (Л.Л. Бочкарёв, Л.В. Школяр, А.В. Торопова, А.Л. Готсдинер, Б.М. Теплов);

- музыкознания и композиции (Ю.Б. Алиев, Н.В. Туманина, П.Е. Вайдман, А.В. Амброс, С. Айзенштадт);

- музыкальной педагогики и методики обучения (Е.Д. Критская, В.В. Крюкова).

Выявлению специфики музыки для детей посвящена, как упоминалось, статья ведущего отечественного теоретика первой половины XX века Б.В. Асафьева «Русская музыка для детей и о детях» (1948). С учетом огромного значения сочинений для детской аудитории в советской музыке Асафьев прослеживает истоки формирования традиций «детской» музыки, находя их в творчестве отечественных композиторов XIX века. Он дифференцирует «музыку для детей» и «музыку о детях» [4].

Подход Асафьева позволяет определить любое сочинение детской тематики: сложную психологическую музыку, которая раскрывает особенности детства, интересные для взрослых, своеобразную ностальгию взрослого по цельности и чистоте раннего жизненного этапа, Асафьев называет музыкой о детях; воспоминания о собственных детских радостях и интересах, занимательных картинах детства, некий диалог с реальным или воображаемым ребенком, предполагающий разговор о близких и понятных ребенку вещах «на его языке», автор относит к музыке для детей [4, с. 97].

Результаты. Мировое искусство подарило детям множество превосходных сочинений, разных по своим художественно-эстетическим качествам и значимости для общего и музыкального развития ребенка [3; 6]. Музыкальное восприятие развивается у детей в процессе творческой деятельности, поэтому в музыке для детей делается акцент на выразительных образах и ярких эмоциях. Эффективность развития музыкального восприятия обеспечивается слушательским опытом ребенка, и чем большей информацией обладает воспитанник, тем понятнее ему содержание музыки. У ребенка при этом в силу возрастных психологических 
особенностей музыка вызывает более богатые ассоциации с явлениями и процессами окружающего мира и яркий эмоциональный отклик на более высоком уровне, чем у взрослых [5].

Прослушивая незнакомое музыкальное произведение, ребенок сначала получает общее представление о музыкальном образе и переживает эмоциональные чувства, непосредственно вызванные музыкой. Образ, появляющийся у ребенка на первом этапе восприятия музыки, может быть разным по своей глубине. Дети еще не осознают все используемые композитором средства музыкальной выразительности, однако уже способны воспринимать целостный образ произведения. С помощью жестов, мимики, движений, а также обдумывания услышанной музыки дети способны вполне точно выразить характер и настроение определенного произведения, представить «героя» произведения благодаря конкретно-образному мышлению.

Второй этап музыкального восприятия определяется повторными прослушиваниями музыкальных произведений целиком или отрывками, в ходе которых дети более глубоко вникают в содержание композиций, выделяют в них наиболее яркие эпизоды, связывают средства музыкальной выразительности с воплощаемыми чувствами и образами. Ребенок видит музыкальный образ разностороннее, а смысл - многограннее. На данном этапе происходит основное восприятие музыки: «Под основным восприятием музыкального произведения подразумевается восприятие, связанное с его эстетической оценкой и осознанием содержания музыки, ее идеи, характера переживания и всех выразительных средств, формирующих музыкальный образ» [16, с. 68].

На третьем этапе происходит взаимодействие целостного образа произведения и общего эмоционального впечатления с аналитическим его восприятием, обусловленным глубоким осмыслением средств музыкальной выразительности и содержания композиции [7]. Особую роль в работе с детьми играет слово учителя, которое активизирует восприятие ребенка, способствует пониманию музыки, положительно влияет на мыслительную и аналитическую деятельность учащихся.

Учитывая психофизиологические особенности ребенка, важной становится смена видов деятельности на уроке во избежание быстро наступающего утомления ученика на уроке, рассеивания внимания и замедления процесса восприятия. Подбирая приемы и методы работы с детьми младшего школьного возраста, важно помнить, что любой музыкальный материал проще воспринимается в игровой форме обучения: это активизирует воображение, внимание, способствует развитию креативности личности. Развитие восприятия музыки у школьника благоприятно сказывается на его художественно-образном мышлении, улучшает мыслительные и эмоциональные процессы, обогащает художественный и жизненный опыт учащегося, стимулирует эстетические эмоции [1].

0бсуждение. Особенности восприятия музыки детьми предопределяют специфику жанров детской музыки. В целом основные качества музыки для детей такие же, как и у музыки «взрослой». Но всё же она имеет свои отличия. Это определяется прежде всего спецификой того, как дети ощущают и воспринимают окружающий мир [20]. С этими ощущениями и восприятием связаны особенности образного строя детской музыки и средства музыкальной выразительности. Детская музыка максимально приближена к сфере эмоциональных ощущений ребенка, его видению мира.

Детское восприятие ориентировано, прежде всего, на один, как правило, самый яркий элемент музыкального произведения, который символизирует конкретную ситуацию, образ, процесс [9]. Такая приверженность к одному элементу при построении образа приводит к восприятию фрагментами, целостный же образ складывается из нанизывания нескольких фрагментов. Поэтому сложность и многозначность музыкального образа затрудняет его восприятие ребенком $[17 ; 19]$. Яркие картинки, написанные современным языком, очень восторженно воспринимаются детской аудиторией. Они охотнее слушают музыку эффектную, выразительную, вызывающую яркие и конкретные впечатления. Детская музыка должна 
быть ярко образной, способной увлечь воображение, взбудоражить фантазию. Специфика детской музыки не в лексике, а в чистоте, цельности и целомудрии восприятия жизни, свойственного детям. Именно это восприятие жизни призван постичь и воссоздать автор, пишущий музыку для детей.

В истории музыки все композиторы, обращавшиеся к детской аудитории, неизменно учитывали особенности восприятия музыки детьми. В результате большой и яркий музыкальный пласт детской музыки образовался на протяжении более чем 200-летнего развития жанров музыки для детей. Начало им положили нотные тетради и книжки И.С. Баха, затем последовали детские и юношеские альбомы для обучения игре на фортепиано, наконец, циклы пьес, иллюстрирующих простые и понятные каждому ребенку предметы и явления, которые были предназначены для их слухового восприятия.

С середины XIX века в Европе появляются научные работы, посвященные проблемам музыкального развития и воспитания детей. Выходят сборники детских стихов и песен, учебники и пособия для музыкальных занятий в семье и школе, теоретическая и методическая литература по этим вопросам. Однако задача создания музыки для детей не ставилась как общественная проблема. Отдельные произведения появлялись по желанию композиторов, осознавших необходимость в такой музыке и испытавших внутреннюю потребность в ее создании. Великие композиторы умели заглянуть в тайники детской души, с тонко отточенным мастерством и большой степенью художественной выразительности раскрыть некоторые стороны детской психики, детских представлений и чувствований.

Лучшие образцы музыки для детей характеризуются точной направленностью содержания и формы художественного воплощения произведения к слушателю. Они привлекают детское внимание простыми и яркими музыкальными образами, запоминающейся мелодией. В таких произведениях точно воспроизводится характерная возрастная детская интонация отношение к описываемому событию, его эмоциональному восприятию.

Музыка для детей занимает достойное место в мировой музыкальной культуре. Правда, в русской музыке музыка для детей появилась гораздо позже, чем в западноевропейской, что связано с более поздним развитием инструментальной культуры в России. Произведения разных жанров, такие как прелюдии, инвенции, сонаты и сонатины, предназначались для детей, но, как правило, не несли в себе определенной детской специфики.

B XIX веке становится популярен жанр цикла фортепианных миниатюр: «Детские сцены» и «Альбом для юношества» Р. Шумана, «Детский альбом» и «Времена года» П.И. Чайковского, «Карнавал животных» К. Сен-Санса. Эта традиция сохранится в XX веке, о чем свидетельствуют «Детская музыка» (соч. 65) С.С. Прокофьева, «Детский альбом» Г.В. Свиридова и др. Эти произведения имеют небольшой объем, разнообразие характеров и образов, богатое стилистическое и жанровое разнообразие.

Жанр домашнего альбома стал типичным для западноевропейского и русского искусства эпохи романтизма. Постепенно из мира литературы и изобразительного искусства жанр альбома модулировал в область музыки. Музыкальный альбом имел несколько разновидностей, причем одной из главных стал детский альбом. Подобные названия имеют два связанных друг с другом произведения XIX века - «Альбом для юношества» Р. Шумана и «Детский альбом» П.И. Чайковского. Их общие черты прослеживаются в цикличности композиции, программности пьес, некоторых жанрово-тематических взаимосвязях. Различия между циклами заключаются в следующем: принадлежность к разным композиторским школам (немецкой и русской): принадлежность к разным хронологическим этапам романтизма как ведущего музыкального направления XIX века - зрелого (Шуман) и позднего (Чайковский в послеонегинский период); разный масштаб («Альбом» Шумана по количеству пьес в 2 раза превышает сочинение Чайковского); композиция цикла и адресат произведения.

Коренной переворот произошел в первой половине XIX века. Композитор-романтик Р. Шуман создает такие циклы, как «20 песен для больших и маленьких детей», «Детские 
сцены», «Альбом для юношества», «Альбом песен для юношества». В этих произведениях композитор воспевает мир детства, переживания ребенка, его игры, правдивые истории из жизни. Таким образом, Р. Шуман открывает перед композиторами новые музыкальные горизонты для запечатления в музыкальных образах бесконечного богатства и многообразия детского мира.

Создавая «Детский альбом», Чайковский воплотил детские идеалы радости и жизни, так как он руководствовался не только задачей музыкального развития ребенка, но и ностальгией по детству с его радостью жизни и чистотой мировосприятия [2]. «Альбом для юношества» Р. Шумана в большей степени педагогически ориентирован, выстроен по принципу «от простого к сложному». В нем отражены широкие идеи музыкального и эстетического воспитания (они сформулированы в предисловии - «Жизненных правилах для музыкантов»). Эти правила не устарели и остались актуальными до настоящего времени.

В своем цикле Шуман стремится раскрыть внутренний мир ребенка и создает тонкие психологические миниатюры, давая удивительно точные названия пьесам. Это позволяет нам отнести «Альбом для юношества» к музыке о детях. Для Шумана очень важно подчинение техники художественному образу, поэтому в «Альбоме для юношества» отсутствует техника в чистом виде, как это было принято у классиков, нет гамм, арпеджио, ритмических сложностей - отсутствие технических трудностей восполнено высокими художественно-эстетическими качествами [13, с. 23].

«Детский альбом» Чайковского имеет определенное направление - смена разных видов деятельности детей с воспоминаниями о самом важном, о том, что было интересно, что занимало в детстве. Эта линия занимательности и составляет суть «Детского альбома». Лирическая мелодика заставляет фортепиано петь, грустить, веселиться, а контрастный тематический материал изображает забавные сценки и рассказывает сказки. Чайковский обращает особое внимание на детскую психологию и в то же время идеализирует раннюю пору жизни.

В циклах Шумана и Чайковского впервые перед слушателем в циклической форме предстает мир, каким видит его ребенок, главным содержанием которого являются игры, сказки, танцы, игрушки, сюрпризы [8]. Это общие темы и «Детского альбома», и «Альбома для юношества», хотя каждый из циклов обладает своеобразием и демонстрирует разные этапы немецкого и отечественного романтизма.

Идею детских альбомов продолжили развивать С. Майкапар («Бирюльки», 1900), А. Гречанинов («Детский альбом», 1923), С. Прокофьев («Детская музыка», 1935) и многие другие композиторы XX века. Пьесы из этих сборников соответствуют требованиям и «музыки для детей», и «музыки о детях»: ясная структура, простота исполнения и «детский» круг образов, поэтому их активно используют в педагогической практике. Помимо музыки для детей, которая предназначена для ее исполнения детьми на фортепиано, существуют разнообразные циклы для их прослушивания детьми в целях общемузыкального и общеэстетического развития, а также культурного развлечения. Это сюиты Бизе, Дебюсси, сказки Прокофьева и оркестровые циклы русских и зарубежных композиторов, представляющие собой путеводители по инструментам классического оркестра. Кульминации развития музыка для детей достигла в XX веке в творчестве С.С. Прокофьева и Б. Бриттена.

Заключение. Внутренний мир ребенка, безусловно, отличается от внутреннего мира взрослого человека. Это значит, что и музыка, предназначенная для детей, должна отвечать следующим требованиям: ясная структура, простота с точки зрения исполнительства, круг образов, с которыми дети имеют дело изо дня в день: игры и забавы, сказки и страшилки, реальные люди и фантастические персонажи. Подобно детской литературе, музыка для детей призвана на понятном для детей языке рассказать о добре и мире, научить их понимать разные эмоции, делиться своими мыслями и чувствами [10; 12] и даже уметь преодолевать психологические проблемы и стабилизировать свою эмоциональную сферу $[11 ; 18]$. 
Детская музыка - тема «вечная» и «священная», как любовь к детям и забота о них. К написанию произведений для детей обращались практически все композиторы, потому что музыка органично входит в мир ребенка с самой ранней поры жизни. Достаточно вспомнить колыбельные, пестушки, музыкальные считалочки, песни и танцы, игры и сказки, детские оперы. Главный аспект тематики музыки для детей связан с образовательной и воспитательной функцией. В России, начиная с древних времен, музыкальное образование детей отличалось самобытным характером, и к нему всегда проявляли особый интерес. В число обязательных учебных предметов входила музыка (пение). Однако, несмотря на глубокие корни, статус самостоятельного и многопланового направления в искусстве тема детства получила сравнительно недавно, открыв широкие перспективы ее изучения.

\section{Список литературы}

1. Аверин В. Психология детей и подростков. СПб., 1998. 397 с.

2. Айзенштадт С.А. «Детский альбом» П.И. Чайковского. М.: Классика-XXI, 2003.78 с.

3. Алиев Ю.Б. Детская музыка // Музыкальная энциклопедия: в 6 т. Т. 2. М.: Сов. энциклопедия, 1974. С. 204-208.

4. Асафьев Б.В. Избранные труды: в 5 т. Т. 4. М.: Изд-во Академии наук СССР, 1955. 490 с.

5. Бочкарев Л.Л. Психология музыкальной деятельности. М.: Ин-т психологии РАН, 2011. 352 c.

6. Кандинский А., Аверьянова 0., Орлова Е. Русская музыкальная литература. Вып. 3. М.: Музыка, 2014. 464 с.

7. Критская Е.Д. Восприятие музыки как педагогическая проблема / Школяр Л.В., Красильникова М.С., Критская Е.Д. и др. Теория и методика музыкального образования детей. М.: Наука, 2009. С. 80-107.

8. Мамонтова Л.И. Образы в произведениях П.И. Чайковского и Р. Шумана. СПб.: Знание, 1995. 35 c.

9. Мухина В.С. Возрастная психология: Феноменология развития, детство, отрочество. М.: ACADEMIA, 1999. $433 \mathrm{c}$.

10. Немировская И.А. Феномен детства в творчестве отечественных композиторов второй половины XIX - первой половины XX века: автореф. дис. ... д-ра искусствоведения. Магнитогорск, 2011. $48 \mathrm{c}$.

11. Переверзева М.В. Арт-терапевтические технологии на основе музыкального фольклора, направленные на преодоление психологических проблем и развитие эмоционального восприятия детей // Инклюзия в образовании. Т. 4. 2019. № 1 (13). С. 19-31.

12. Переверзева М.В. Музыка и юмор в произведениях канадских композиторов XX века // Музыковедение. 2018. № 4. С. 21-27.

13. Смирнова М.В. Р. Шуман «Альбом для юношества», П. Чайковский «Детский альбом», К. Дебюсси «Детский уголок», С. Прокофьев «Детская музыка». СПб.: Композитор, 2013. 185 с.

14. Теплов Б.М. Психология музыкальных способностей. М., 2005. 355 с.

15. Торопова А.В. Музыкальная психология и психология музыкального образования: учеб. пособие. М.: ГРАФ-ПРЕСС, 2008. 250 c.

16. Шацкая В.Н. Музыкально-эстетическое воспитание детей и юношества. М., 1986.

17. Anufrieva N., Avramkova I., Korsakova I., Pereverzeva M.V., Shcherbakova A. Orientation of musical disciplines as a condition for the formation of competencies // Opcion. 2018. No. 34 (Special Issue 17). P. 719-730.

18. Davydova A.A., Pereverzeva M.V., Tsarev D.V., Shcherbakova A.I., Shcherbinina V.M. Musical Art-Therapeutic Technologies of Overcoming Psychological Problems and Developing the Emotional Perception of Children // Journal of Pharmaceutical Sciences and Research. 2018. Vol. 10 (4). P. 846-848.

19. Koposova I.V. Musical form and its elucidation in school textbooks of music literature // Music Scholarship. 2019. No. (2). P. 178-189.

20. Shafazhinskaya N.E., Shcherbinina V.M., Ivanova E.Y., Belyakova T.E., Pereverzeva M.V. Learning about world art culture as a method of forming a universal cross-cultural communication competence // Humanities \& Social Sciences Reviews. Vol. 7. 2019. No. 6. P. 1225-1229.

\section{References}

1. Averin V. Psikhologiya detej i podrostkov. SPb., 1998. $397 \mathrm{s.}$ 
2. Ajzenshtadt S.A. «Detskij al'bom» P.I. Chajkovskogo. M.: Klassika-XXI, 2003. 78 s.

3. Aliev Yu.B. Detskaya muzyka // Muzykal'naya enciklopediya: v 6 t. T. 2. M.: Sov. enciklopediya, 1974. S. 204-208.

4. Asaf'ev B.V. Izbrannye trudy: v 5 t. T. 4. M.: Izd-vo Akademii nauk SSSR, 1955. $490 \mathrm{~s}$.

5. Bochkarev L.L. Psikhologiya muzykal'noj deyatel'nosti. M.: In-t psikhologii RAN, 2011. $352 \mathrm{~s}$.

6. Kandinskij A., Aver'yanova 0., Orlova E. Russkaya muzykal'naya literatura. Vyp. 3. M.: Muzyka, 2014. $464 \mathrm{~s}$.

7. Kritskaya E.D. Vospriyatie muzyki kak pedagogicheskaya problema / Shkolyar L.V., Krasil'nikova M.S., Kritskaya E.D. i dr. Teoriya i metodika muzykal'nogo obrazovaniya detej. M.: Nauka, 2009. S. 80-107.

8. Mamontova L.I. Obrazy v proizvedeniyakh P.I. Chajkovskogo i R. Shumana. SPb.: Znanie, 1995. $35 \mathrm{~s}$.

9. Mukhina V.S. Vozrastnaya psikhologiya: Fenomenologiya razvitiya, detstvo, otrochestvo. M.: ACADEMIA, 1999. $433 \mathrm{~s}$.

10. Nemirovskaya I.A. Fenomen detstva $v$ tvorchestve otechestvennykh kompozitorov vtoroj poloviny XIX - pervoj poloviny XX veka: avtoref. dis. ... d-ra iskusstvovedeniya. Magnitogorsk, 2011. $48 \mathrm{~s}$.

11. Pereverzeva M.V. Art-terapevticheskie tekhnologii na osnove muzykal'nogo fol'klora, napravlennye na preodolenie psikhologicheskikh problem i razvitie emocional'nogo vospriyatiya detej // Inklyuziya v obrazovanii. T. 4. 2019. № 1 (13). S. 19-31.

12. Pereverzeva M.V. Muzyka i yumor v proizvedeniyakh kanadskikh kompozitorov XX veka // Muzykovedenie. 2018. № 4. S. 21-27.

13. Smirnova M.V. R. Shuman «Al'bom dlya yunoshestva», P. Chajkovskij «Detskij al'bom», K. Debyussi «Detskij ugolok», S. Prokof'ev «Detskaya muzyka». SPb.: Kompozitor, 2013. $185 \mathrm{~s}$.

14. Teplov B.M. Psikhologiya muzykal'nykh sposobnostej. M., 2005. 355 s.

15. Toropova A.V. Muzykal'naya psikhologiya i psikhologiya muzykal'nogo obrazovaniya: ucheb. posobie. M.: GRAF-PRESS, 2008. $250 \mathrm{~s}$.

16. Shackaya V.N. Muzykal'no-esteticheskoe vospitanie detej i yunoshestva. M., 1986.

17. Anufrieva N., Avramkova I., Korsakova I., Pereverzeva M.V., Shcherbakova A. Orientation of musical disciplines as a condition for the formation of competencies // Opcion. 2018. No. 34 (Special Issue 17). P. 719-730.

18. Davydova A.A., Pereverzeva M.V., Tsarev D.V., Shcherbakova A.I., Shcherbinina V.M. Musical Art-Therapeutic Technologies of Overcoming Psychological Problems and Developing the Emotional Perception of Children // Journal of Pharmaceutical Sciences and Research. 2018. Vol. 10 (4). P. 846-848.

19. Koposova I.V. Musical form and its elucidation in school textbooks of music literature // Music Scholarship. 2019. No. (2). R. 178-189.

20. Shafazhinskaya N.E., Shcherbinina V.M., Ivanova E.Y., Belyakova T.E., Pereverzeva M.V. Learning about world art culture as a method of forming a universal cross-cultural communication competence // Humanities \& Social Sciences Reviews. Vol. 7. 2019. No. 6. P. 1225-1229.

\section{Библиографическое описание статьи / Reference to article}

Круглова М.Г., Григорьева Е.И. Особенности восприятия музыки детьми и их влияние на жанры детской музыки // Ученые записки Российского государственного социального университета. T. 19. 2020. № 1 (154). C. 137-143. DOI: 10.17922/2071-5323-2020-19-1137-143 (Библиографическое описание согласно российским стандартам).

Kruglova M.G., Grigor'eva E.I. Osobennosti vospriyatiya muzyki det'mi i ikh vliyanie na zhanry detskoj muzyki // Uchenye zapiski Rossijskogo gosudarstvennogo social'nogo universiteta. T. 19. 2020. № 1 (154). S. 137-143. DOI: 10.17922/2071-5323-2020-19-1-137-143 (Reference in Roman script).

Kruglova, M.G. \& Grigorieva, E.I. (2020) Features of Children's Perception of Music and Their Impact on Children's Music Genres, Scientific Notes of Russian State Social University. Vol. 19. No. 1 (154). P. 137-143. DOI: 10.17922/2071-5323-2020-19-1-137-143 (International bibliographic description). 


\title{
С.С. Аксенова,
}

преподаватель кафедры искусств и художественного творчества,

Российский государственный социальный университет, Москва.

S.S. Aksenova,

lecturer of the department of arts and artistic creativity,

Russian State Social University, Moscow.

E-mail: aksenova_sofia@mail.ru

\section{М. Габдиев,}

Заслуженный деятель Республики Казахстан, старший преподаватель

кафедры музыки и искусств Атырауского государственного университета

им. Х. Досмухамедова, Атырау.

M. Gabdiyev,

Honored worker of the Republic of Kazakhstan, senior lecturer of the department

of music and arts of Atyrau State University named after H. Dosmukhamedov,

Atyrau.

E-mail: Gabdieva_assel@mail.ru

\section{Специфика методов обучения детей младшего шाкольного возраста основам әстрадного вокального искусства}

\author{
Specific Methods of Teaching Children \\ of Primary School Age the Basics of Variety Vocal Art
}

Дата поступления
12.12.2019
Дата препринта

28.02.2020
Дата публикации

30.03.2020

Аннотация: постановка голоса у детей младшего школьного возраста представляет сложный учебно-воспитательный процесс, в основе которого лежат как знания педагога-вокалиста о психофизиологических особенностях каждого обучающегося, так и профессиональное владение методикой вокального обучения. Специфика отбора методики обучения эстрадному вокалу детей заключается в том, чтобы педагогические принципы и подходы, цели и задачи методики, а также конкретные упражнения и структура занятий решали основные проблемы формирования певческого аппарата младшего школьника и соответствовали способностям и возможностям ребенка данного возраста. Именно поэтому для каждого ребенка подбирается не только индивидуальный учебный репертуар, но и конкретная методика обучения. В статье анализируются современные методы обучения детей младшего школьного возраста основам эстрадного вокального искусства и выявляется специфика их применения.

Annotation: voice-making in children of primary school age represents a complex educational process, which is based on both the knowledge of the teacher-vocalist about the psychophysiological peculiarities of each student and professional knowledge of the methodology of vocal education. The specifics of selection of the method of teaching variety vocal of children is that pedagogical principles and approaches, goals and objectives of the method, as well as specific exercises and structure of classes solve the main problems of formation of singing apparatus of the junior schoolboy and correspond to abilities and capabilities of the child of this age. That is why not only the individual educational repertoire is selected for each child, but also 
a specific teaching methodology. The article analyses modern methods of teaching children of primary school age the basics of variety vocal art and identifies the specifics of their application.

Ключевые слова: методы обучения, эстрадное вокальное искусство, младшие школьники, постановка голоса.

Key words: teaching methods, variety vocal art, junior students, voice production.

Введение. Специфика отбора методики обучения эстрадному вокалу детей заключается в том, чтобы педагогические принципы и подходы, цели и задачи методики, а также конкретные упражнения по постановке голоса и структура занятий пением решали основные проблемы формирования певческого аппарата младшего школьника и соответствовали способностям и возможностям ребенка данного возраста. Именно поэтому для каждого ребенка подбирается не только индивидуальный учебный репертуар, но и конкретная методика обучения. В процессе вокальных занятий необходимо приобретение умений и навыков дыхания, звукообразования, дикции.

Методика. Проблемы методики вокального обучения анализируются во многих научных исследованиях Т.Б. Решетниковой, Н.П. Варшавской, А.В. Басовой, Л.Г. Боровик, Е.Ю. Медведевой, Л.Б. Дмитриева, Н.Р. Усаевой и др.

Н.П. Варшавская обосновывает три основных принципа обучения эстрадному вокалу:

«1) индивидуальный подход к каждому ученику;

2) постепенность и последовательность усложнения музыкальных и вокально-технических задач;

3) единство художественного и вокально-технического развития ученика» [3, с. 4].

Необходимость индивидуального подхода к каждому обучающемуся подчеркивает и Н.Р. Усаева: «Важно учитывать различный уровень довузовской подготовки студентов, а также их индивидуально-психологические свойства» [15, с. 107]. По справедливому утверждению Н.Р. Усаевой, индивидуальность будущего эстрадного вокалиста может в полной мере проявиться в различных формах внеучебной деятельности, способствующих развитию артистических качеств.

0 равномерности и последовательности формирования вокальных навыков детей писали многие педагоги-вокалисты, начиная с У.А. Мазетти, который предлагал четыре вида вокальных упражнений: выдержанные ноты, гаммы, арпеджио и украшения (мелизмы). Он предлагал начинать обучение вокалу с гласной «а», затем переходить к «о», «е». Пение совершается с той же легкостью, что и разговорная речь.

Связь художественного воспитания и вокально-технических задач подчеркивает Ю.Б. Эдельман: «Главная задача воспитания певца - это качество вокального звука. Дыхание, опора, резонаторы, гортань - всё должно прийти в гармонию» [17, с. 60]. Автор характеризует основные пути достижения качества вокального звучания.

«1. Ровность звукоряда: ровная, выстроенная гамма.

2. Правильная артикуляция.

3. Свобода мышечного и голосового аппарата.

4. Соответствие певческого звука тому, что композитор “задумал" в своем произведении» $[17$, с. 62].

Исследование Т.Б. Решетниковой посвящено процессу постановки голоса вокалиста, включающему в себя «слуховое восприятие, умственные операции и вокальное воспроизведение» $[12$, с. 91]. Автор акцентирует внимание на необходимости формирования навыков дыхания. Проблемы дыхания и звукообразования в пении исследуются и Н.П. Варшавской. Автор предлагает начинать обучение детей вокалу с примарных тонов, акцентируя внимание на взаимодействии головного и грудного резонаторов: «Высокие и переходные звуки связаны с головными резонаторами, низкие - с грудными» [3, с. 11].

В исследованиях А.В. Басовой и Е.Ю. Медведевой анализируются проблемы певческой артикуляции. Необходимо отметить, что основой пения являются гласные звуки, формируе- 
мые в подскладочных полостях гортани. Гласные формируют красоту тембра, вибрато, певческие форманты. А.В. Басова, дифференцируя звонкие и глухие согласные, пишет о необходимости «округления звонких $u, e$, а также приближения глухих о, у к звонким» [1, с. 27]. Важным аспектом исследования А.В. Басовой является утверждение об индивидуальном положении губ вокалиста, зависящем от характера голоса певца.

Важным аспектом развития дикции у детей, обучающихся вокалу, является непосредственная связь с лучшими произведениями музыкальной классики. Е.Ю. Медведева, обращая внимание на фонетическое воспитание голоса ребенка, акцентирует внимание на произведениях М.И. Глинки [8, с. 12].

Результаты. В процессе постановки голоса ребенка его диапазон постепенно расширяется; приобретается необходимая сила голоса и его устойчивость к утомлению. Существуют также отличия в процессе голосообразования речевой и вокальной интонации. Как отмечают Е.Г. Малышева и А.Ю. Крылов, в процессе пения происходит «более значительное, нежели в речевом произношении, поднятие мягкого неба и, наоборот, более низкое положение спинки языка; для пения характерны повышенный тонус мышц глубинной части ротоглоточной полости, а также более широкое раскрытие рта» [7, с. 9]. Существуют также определенные различия в дыхании. В процессе пения дыхательные движения менее интенсивны, нежели в устной речи. Певческое дыхание глубже обычного, выдох длиннее речевого. Количество выдыхаемого воздуха неравномерно и определяется певческими задачами: силой звука, фразировкой и др.

Важной задачей постановки голоса является формирование и развитие навыков самостоятельной работы по совершенствованию вокального мастерства. Ограниченное время практических занятий с педагогом не может привить обучающемуся комплекс вокальных умений. В статье Н.Р. Усаевой есть ценные методические указания вокалистам по организации их самостоятельной работы. В частности, автор рекомендует обучающимся не переутомлять голос, распеваться в удобном диапазоне на простых упражнениях, не браться за слишком трудные произведения, систематически заниматься вокалом.

Постановка голоса является одной из главных проблем обучения детей эстрадному вокалу и во многом зависит от личностных качеств учащегося. Педагог-вокалист уже на первоначальных этапах обучения должен учитывать особенности общения с детской аудиторией. Наиболее приемлемым в современной общей и музыкальной педагогике, на наш взгляд, является диалогический стиль общения. Как отмечает В.И. Петрушин, «при диалогическом взаимодействии сохраняется равноправие высказываемых суждений, и каждый участник стимулирует своими высказываниями рассуждения своего партнера» [10, с. 313]. В основе диалогического стиля общения должен быть голос педагога, убежденного в своих знаниях и возможностях обучающихся к восприятию знаний.

На занятиях эстрадным вокалом с младшими школьниками в детских школах искусств используются общепедагогические наглядные, словесные и практические методы работы с детьми. При этом наглядный метод представлен такими разновидностями, как наглядно-слуховой (исполнение произведения самим педагогом); наглядно-зрительный (пение по нотам, обучение по видеозаписям и т.д.) и наглядно-двигательный (движения под музыку, пластическая интонация). Словесный метод включает в себя объяснение и диалог, необходимые младшим школьникам ввиду отсутствия специальных знаний о формировании певческого аппарата и механизме его работы. Практический, или демонстрационный, метод эффективен именно в обучении пению, поскольку позволяет школьникам понять, оценить и проанализировать полученную информацию и применить ее на практике в процессе выполнения упражнений.

Методика обучения эстрадному вокалу подразумевает формирование и развитие следующих элементов вокального, в том числе эстрадного, исполнительства.

1. Певческая установка. Дыхание как источник энергии для возникновения звука. Прежде чем начинать занятия эстрадным пением, с учащимися проводится дыхательная разминка и упражнения на певческую установку. 
2. Дикция: культура, орфоэпия и логика речи. Дикция развивается благодаря пению учебно-тренировочного материала, проговариванию слоговых упражнений и скороговорок.

3. Развитие диапазона и динамики голоса. Для обретения силы звука (интенсивности) используются следующие упражнения:

- упражнение на активизацию дыхания;

- стаккатное упражнение;

- легатное упражнение;

- спинное дыхание 1-1,5 минуты;

- активный вдох, активный выдох 1-2 минуты;

- равномерный выдох 7-10 раз;

- приемы филирования звука [4, с. 3].

4. Формирование базовых вокально-исполнительских приемов и навыков в эстрадной манере:

- расщепление;

- субтон;

- пение с придыханием;

- обертоновое пение («горловое пение»);

- глиссандо (плавный переход с ноты на ноту);

- фальцет;

- пение «без опоры»; и др.

5. Формирование основных исполнительских навыков. Использование разных видов динамики и исполнительских приемов. Воспитание навыков понимания основных художественно-выразительных средств звучания голоса.

6. Работа над сценическим образом. Фразировка, вытекающая из музыкального и текстового содержания. Формирование навыков эмоционально-выразительного художественного исполнения.

7. Формирование художественного мышления. Развитие способности к музыкально-образным представлениям. Активизация творческого воображения путем ассоциаций.

В процессе освоения учебного репертуара с детьми необходимо проводить работу по анализу содержания песни и поиску адекватной ему формы сценического решения. Ребенок осваивает также средства и приемы сценического поведения эстрадного вокалиста:

- умение свободно вести себя на сцене;

- умение пластично двигаться;

- соответствие постановки номера содержанию песни;

- уровень художественного вкуса, проявленный при создании костюмов и реквизита;

- оригинальность интерпретации образа и манеры исполнения.

Через осмысление, эмоциональное погружение важно донести образ (идею) исполняемого эстрадно-вокального произведения. Соответственно, все технические навыки, которыми учащиеся овладевают на занятиях вокала, помогают достигнуть наиболее убедительного результата. В процессе занятий происходит развитие воображения, фантазии, внимания, памяти, мышечной свободы, пластичности. При этом комплекс дисциплин должен иметь профессиональную направленность, чтобы необходимые навыки формировались многосторонне [19].

Голосовой аппарат младших школьников нестабилен. Главная задача обучения детей указанного возраста - очень бережное отношение к голосу. Занятия пением необходимы, однако их нужно проводить в удобном диапазоне, с опорой на примарные тоны. Помимо этого педагогу-вокалисту следует постоянно обращать внимание учащихся на необходимость гигиены голоса. Для активной работы на уроках эстрадного вокала голосовой аппарат ребенка должен находиться в здоровом состоянии.

Обсуждение. Таким образом, педагоги-вокалисты подчеркивают важность тех или иных сторон вокального обучения, поэтому специфика отбора методики обучения эстрадному во- 
калу детей заключается в том, чтобы педагогические принципы и подходы, цели и задачи методики, а также конкретные упражнения и структура занятий решали основные проблемы формирования певческого аппарата младшего школьника и соответствовали способностям и возможностям ребенка данного возраста. Учитываются также и интересы самих учеников, многие из которых предпочитают музыку современных стилей, которая далеко не всегда входит в учебный репертуар учебных заведений [20]. Именно поэтому для каждого ребенка подбирается не только индивидуальный учебный репертуар, но и конкретная методика обучения. Среди современных исследователей показали эффективность методики Л.Г. Боровик, Н.П. Варшавской, О.В. Кацер, Л.В. Романовой, Ю.В. Савельевой, разработанные специально для детей и проверенные на практике.

Процесс вокального обучения младших школьников включает в себя развитие голоса и формирование основных элементов вокальной техники. Вокальная техника включает в себя комплекс упражнений, предназначенных для освоения обучающимися элементов дыхания, звукоизвлечения, дикции. Важной особенностью упражнений является их сравнительная простота, легкость восприятия. Каждый урок вокала может быть построен по следующему плану:

- подготовительный этап;

- основная часть урока;

- заключение.

Подготовительный этап включает в себя различные виды массажа, в том числе вибрационного:

- растирание ладоней; ладони должны быть теплыми;

- разглаживание двумя пальцами лобных пазух от виска к виску;

- подготовка гайморовых пазух от уголков глаз к уху;

- рисование «гусарских усов», двумя пальцами, от уха к уху;

- поворот шеи вправо, влево. Темп умеренный. Массаж мышц шеи с двух сторон;

- мычание на одной высоте (в примарной зоне диапазона). Используя звуки «ж», «з», «р», постучать подушечками пальцев: по лбу, гайморовым пазухам, щекам, груди, животу.

В процессе подготовительного этапа урока возможны упражнения: для языка, гортани, нижней челюсти, подвижности губ, произношения согласных звуков, сочетания согласных и гласных в фразовой речи.

Занятия включают в себя разные виды вокальных упражнений, направленных на достижение ровности звучания голоса, развития дыхания, тренировки диафрагмы и др. Все упражнения делятся на следующие группы:

- пение с закрытым ртом, негромко, ощущая звук в области переносицы, что дает возможность услышать головное резонирование и настроиться на высокую позицию;

- упражнения, служащие одновременно для выравнивания гласных и тренировки диафрагмы. Их нужно петь строго legato, ровным звуком, на полном «зевке»;

- пение секунд и терций как основных интервалов вокала. Упражнения поются ровно, без толчков. Слоги можно менять для отработки одинакового звучания всех гласных на «зевке»;

- упражнения на staccato, формирующие эластичную диафрагму. Петь следует легко, без нажима, как бы укалывая звук, активно работая диафрагмой (на гласные «a», «о», «и» или на любой слог);

- пение гамм, помогающее тренировать дыхание, расширять диапазон голоса. Необходимо зафиксировать первый звук в высокой позиции, сохраняя ее до конца упражнения, не «выстреливая» верхние звуки (слоги «ми», «ма», «мо»). Первоначальный темп умеренный; в дальнейшем можно взять более подвижный. Возможно увеличение количества повторов элементов гамм;

- упражнения на сочетание элементов legato-staccato (на слогах «ми», «ма», «мо»); 
- пение арпеджио. Необходимо распределять дыхание так, чтобы основное внимание уделить верхней ноте;

- гаммы и арпеджио (слоги «ми», «ма», «мо»).

Каждое упражнение желательно транспонировать по полутонам вверх и вниз.

Изучению вокального репертуара необходимо отводить основное время урока. Мы выделяем следующие критерии подбора репертуара для младших школьников:

1) художественная ценность песен, романсов, арий;

2) соответствие уровню вокальной, общеинтеллектуальной и музыкальной подготовки ребенка;

3) связь репертуара со школьной программой по предмету «Музыка» в общеобразовательной школе.

Приведем несколько примеров работы над репертуаром. М. Красев в песне «Кукушка» создал картину летнего леса. Кукушка, постоянная жительница лесов и полей, поет то тихо, то звонко, приветствуя всех. Форма песни - куплетная АВ. В запеве первого куплета вокалисту необходимо максимально распеть гласную «у», похожую на лесной зов «ау»:

У леса на опушке высоко на суку,

С утра поет кукушка: «Ку-ку! Ку-ку!»

В припеве, помимо гласной «у», распевается «и» - на словах «лиловая черника», «тихо»; звучание ее максимально мягкое, напевное. В запеве второго куплета важно показать уже не утро, но наступивший день. Теперь лягушка поет «звонко», приветствуя и речёонку, и зелёоных лягушек.

Мажорный лад песни, сравнительная несложность интонации с опорой на терцию (зов кукушки), легкость движения в подвижном темпе - все выразительные средства направлены на создание радостного, позитивного настроения летнего утра и начала дня. Песню М. Красева можно выучить с детьми; для более удобного диапазона детских голосов ее желательно транспонировать на 1,5 вниз, в тональность $A-d u r$.

Другой образ птички представлен в песне А. Аренского «Кукушка». Композитор, противореча общему мнению о кукушке, бросающей деток в чужие гнезда, создает ситуацию печали, тоски по утрате своих птенчиков. Лад - минорный, темп - небыстрый; размер 6/8 сообщает движению плавность, закругленность каждой фразы. Вокалисту необходимо распеть гласную «о» - «Там, вдали за рекой раздается порой»; в сочетании с краткой «й» она напоминает горестный вздох «ой».

Зов кукушки - терцовая интонация - есть и в данной песне; однако композитор использует минорную окраску м. Форма - куплетная, с кульминацией в конце третьего куплета. Перед словами «Деток ищет, зовет» в вокальной партии выдержана пауза: в аккомпанементе фортепиано звучат диссонирующие аккорды DD, включающие IV выс. ступень лада. Те же аккорды, а также аккорд альтерированного $D_{7}{ }^{\# 5}$ в тональности $C$-dur, как прерванный оборот основной тональности e-moll, сопровождают горестные возгласы кукушки (такты 7, 8; 13-15; 19-21).

Песня Д. Кабалевского «Артистка» - это небольшая юмористическая сценка. Жанровая основа мелодии и аккомпанемента - полька. Подвижная, легкая песенка первого куплета сменяется более медленным движением во втором (ремарка композитора «скучновато»). Задорный запев («ку-ку, ку-ку») сменяется припевом «Собрался лесной народ слушать, как она поет» в параллельном cis-moll; затем возвращением в основную тональность («3рителей не счесть, негде даже сесть»). Синкопированный ритм аккомпанемента, staccato в баcax - все средства выразительности направлены на создание юмористической ситуации.

Заключение. Для достижения максимального результата обучающихся в области эстрадного исполнительства целесообразно использовать инновационные технологии, внедрение которых способствует большей эффективности учебного процесса. Специфика организации занятий по эстрадному вокалу, методическое и техническое обеспечение напрямую связано с инновационными элементами. 
Освоение различных новых технологий обучения эстрадному вокалу детей является необходимым в современных условиях - в условиях информационного общества. Достижение высоких результатов обучения в классе эстрадного вокала возможно благодаря применению различных методов обучения, подбираемых индивидуально для каждого ребенка ввиду еще не окрепшего голоса, отсутствия большого вокально-исполнительского опыта и необходимых навыков и умений.

\section{Список литературы}

1. Басова А.В. Основы вокальной методики. Эренбург: ИПК гоУ ОГУ, 2010. 105 с.

2. Боровик Л.Г. Научные основы постановки голоса. Челябинск, 2013. 106 с.

3. Варшавская Н.П. Некоторые принципы вокальной методики. Казань: Казан. гос. консерватория (академия), 2007. 28 с.

4. Жилин В. Речевые игры и упражнения. Челябинск: Учитель, 1995. 128 с.

5. Исаева И.О. Эстрадное пение. Экспресс-курс развития вокальных способностей. М.: АСТ : Астрель, 2007. 174 с.

6. Кацер 0.В. Игровая методика обучению детей пению: учеб.-метод. пособие. СПб.: Музыкальная палитра, 2005. 190 с.

7. Малышева Е.Г., Крылов А.Ю. Постановка голоса. Техника речи. Омск: Омск. гос. ун-т им. Ф.М. Достоевского, 2017. 244 с.

8. Медведева Е.Ю. Вокальные сочинения Глинки как учебный репертуар на разных этапах постановки голоса. В. Новгород, 2013. 44 с.

9. Павлова М.А. Лекции по методике обучения сольному пению. М.: Моск. гос. открытый ун-т им. М.А. Шолохова, 2004. 87 с.

10. Петрушин В.И. Музыкальная психология. М.: Академический проект, 2006. 400 с.

11. Развитие детского голоса: матер. науч. конф. / под ред. В.Н. Шацкой. М., 1993. 302 с.

12. Решетникова Т.В. Формирование вокальных навыков на уроках сольного пения // Традиции и инновации в современном культурно-образовательном пространстве: матер. IX Междунар. науч.-практ. конф. М.: МГПУ, 2019. 225 с.

13. Романова Л.В. Школа эстрадного вокала. СПб.: Лань, 2007. 240 с.

14. Савельева Ю.В., Смелкова Т.Д. Основы обучения вокальному искусству. СПб.: Лань : Планета музыки, 2014. 160 с.

15. Усаева Н.Р. Особенности самостоятельной подготовки студентов в классе сольного пения // Актуальные проблемы современной музыкальной педагогики музыкального и художественного образования: сб. ст. и матер. / под ред. Н.Р. Усаева. Сургут: СГПУ, 2006. C. $98-103$.

16. Усарева Н.В., Устьянцева С.Ю. Эстрадный вокал. Камышлов, 1997. 118 с.

17. Эдельман Ю.Б. Уроки пения. М.: Торус Пресс, 2010. 176 с.

18. Ярославцева Л.К. Зарубежные вокальные школы: учеб. пособие. М.: Гос. муз.-пед. институт им. Гнесиных, 1981. 264 с.

19. Anufrieva N., Avramkova I., Korsakova I., Pereverzeva M.V., Shcherbakova A. Orientation of musical disciplines as a condition for the formation of competencies // Opcion. 2018. No. 34 (Special Issue 17). P. 719-730.

20. Davydova A.A, Lushnikov S.S, Pereverzeva M.V., Smirnov A.V., Tsarev D.V. Piano music of composers-minimalists in the teaching repertoire of higher music education // Opcion. 2018. No. 34 (Special Issue 17). P. 149-162.

\section{References}

1. Basova A.V. Osnovy vokal'noj metodiki. Erenburg: IPK GOU OGU, 2010. $105 \mathrm{s.}$

2. Borovik L.G. Nauchnye osnovy postanovki golosa. Chelyabinsk, 2013. $106 \mathrm{~s}$.

3. Varshavskaya N.P. Nekotorye principy vokal'noj metodiki. Kazan': Kazan. gos. konservatoriya (akademiya), 2007. $28 \mathrm{~s}$.

4. Zhilin V. Rechevye igry i uprazhneniya. Chelyabinsk: Uchitel', 1995. $128 \mathrm{s.}$

5. Isaeva I.0. Estradnoe penie. Ekspress-kurs razvitiya vokal'nykh sposobnostej. M.: AST : Astrel', 2007. $174 \mathrm{~s}$.

6. Kacer 0.V. Igrovaya metodika obucheniyu detej peniyu: ucheb.-metod. posobie. SPb.: Muzykal'naya palitra, 2005. $190 \mathrm{~s}$.

7. Malysheva E.G., Krylov A.Yu. Postanovka golosa. Tekhnika rechi. Omsk: Omsk. gos. un-t im. F.M. Dostoevskogo, 2017. 244 s. 
8. Medvedeva E.Yu. Vokal'nye sochineniya Glinki kak uchebnyj repertuar na raznykh etapakh postanovki golosa. V. Novgorod, 2013. $44 \mathrm{~s}$.

9. Pavlova M.A. Lekcii po metodike obucheniya sol'nomu peniyu. M.: Mosk. gos. otkrytyj un-t im. M.A. Sholokhova, 2004. $87 \mathrm{~s}$.

10. Petrushin V.I. Muzykal'naya psikhologiya. M.: Akademicheskij proekt, 2006. $400 \mathrm{~s}$.

11. Razvitie detskogo golosa: mater. nauch. konf. / pod red. V.N. Shackoj. M., 1993. 302 s.

12. Reshetnikova T.V. Formirovanie vokal'nykh navykov na urokakh sol'nogo peniya // Tradicii i innovacii v sovremennom kul'turno-obrazovatel'nom prostranstve: mater. IX Mezhdunar. nauch.-prakt. konf. M.: MGPU, 2019. 225 s.

13. Romanova L.V. Shkola estradnogo vokala. SPb.: Lan', 2007. 240 s.

14. Savel'eva Yu.V., Smelkova T.D. Osnovy obucheniya vokal'nomu iskusstvu. SPb.: Lan' : Planeta muzyki, 2014. $160 \mathrm{~s}$.

15. Usaeva N.R. Osobennosti samostoyatel'noj podgotovki studentov v klasse sol'nogo peniya // Aktual'nye problemy sovremennoj muzykal'noj pedagogiki muzykal'nogo i khudozhestvennogo obrazovaniya: sb. st. i mater. / pod red. N.R. Usaeva. Surgut: SGPU, 2006. S. 98-103.

16. Usareva N.V., Ust'yanceva S.Yu. Estradnyj vokal. Kamyshlov, 1997. $118 \mathrm{s.}$

17. Edel'man Yu.B. Uroki peniya. M.: Torus Press, 2010. $176 \mathrm{s.}$

18. Yaroslavceva L.K. Zarubezhnye vokal'nye shkoly: ucheb. posobie. M.: Gos. muz.-ped. institut im. Gnesinykh, 1981. $264 \mathrm{~s}$.

19. Anufrieva N., Avramkova I., Korsakova I., Pereverzeva M.V., Shcherbakova A. Orientation of musical disciplines as a condition for the formation of competencies // Opcion. 2018. No. 34 (Special Issue 17). P. 719-730.

20. Davydova A.A, Lushnikov S.S, Pereverzeva M.V., Smirnov A.V., Tsarev D.V. Piano music of composers-minimalists in the teaching repertoire of higher music education // Opcion. 2018. No. 34 (Special Issue 17). P. 149-162.

\section{Библиографическое описание статьи / Reference to article}

Аксенова С.С., Габдиев М. Специфика методов обучения детей младшего школьного возраста основам эстрадного вокального искусства // Ученые записки Российского государственного социального университета. Т. 19. 2020. № 1 (154). C. 144-151. D0I: 10.17922/2071-5323-2020-19-1-144-151 (Библиографическое описание согласно российским стандартам).

Aksenova S.S., Gabdiev M. Specifika metodov obucheniya detej mladshego shkol'nogo vozrasta osnovam estradnogo vokal'nogo iskusstva // Uchenye zapiski Rossijskogo gosudarstvennogo social'nogo universiteta. T. 19. 2020. № 1 (154). S. 144-151. D0I: 10.17922/2071-53232020-19-1-144-151 (Reference in Roman script).

Aksenova, S.S. \& Gabdiyev, M. (2020) Specific Methods of Teaching Children of Primary School Age the Basics of Variety Vocal Art, Scientific Notes of Russian State Social University. Vol. 19. No. 1 (154). P. 144-151. DOI: 10.17922/2071-5323-2020-19-1-144-151 (International bibliographic description). 


\title{
М.В. Переверзева,
}

д-р искусствоведения, доцент кафедры социологии и философии культуры,

Российский государственный социальный университет, Москва.

M.V. Pereverzeva,

doctor of art science, associate professor of the department of sociology and

philosophy of culture, Russian State Social University, Moscow.

E-mail: melissasea@mail.ru

\section{М. Габдиев,}

Заслуженный деятель Республики Казахстан, старший преподаватель

кафедры музыки и искусств Атырауского государственного университета

им. Х. Досмухамедова, Атырау.

M. Gabdiyev,

Honored worker of the Republic of Kazakhstan, senior lecturer of the department

of music and arts of Atyrau State University named after H. Dosmukhamedov,

Atyrau.

E-mail: Gabdieva_assel@mail.ru

\section{Специфика развития эмоциональной сферы подростков на занятиях әстрадным вокалом}

\author{
Specifics of Development of Teenagers' Emotional Sphere \\ in Classes with Variety Vocal
}

\author{
Дата поступления \\ Дата препринта \\ Дата публикации \\ 10.12.2019 \\ 28.02.2020 \\ 30.03.2020
}

Аннотация: исследование посвящено использованию потенциала разных музыкальных стилей в преодолении сложного эмоционального состояния современных подростков и специфике развития их эмоциональной сферы в процессе обучения эстрадному вокалу. Занятия эстрадным вокалом способствуют эмоциональной стабилизации подростка, устранению повышенного уровня тревожности, повышению самооценки и самозначимости. На практических занятиях вокалом помимо решения технических и физиологических аспектов исполнительства уделяется пристальное внимание развитию эмоциональной сферы подростка. Исследованию этой актуальной темы посвящена данная статья.

Annotation: the study is devoted to the use of the potential of different musical styles in overcoming the complex emotional state of modern teenagers and the specifics of the development of their emotional sphere in the process of learning variety vocal. Classes of variety vocal contribute to emotional stabilization of the teenager, elimination of increased level of anxiety, increase of their self-esteem and self-recognition. In practical classes vocal, in addition to solving technical and physiological aspects of performance, close attention is paid to the development of the emotional sphere of the teenager. This article is devoted to the study of this topical topic.

Ключевые слова: эмоциональная сфера личности, эстрадный вокал, обучение пению, учащиесяподростки, эмоциональная стабилизация.

Key words: emotional sphere of personality, variety vocal, singing training, teenage students, emotional stabilization.

Введение. В современной психологии и педагогике проблема эмоций личности является самой сложной. Основное внимание исследователей сосредоточено на изучении эмоций 
как фундаментальной сферы психического развития личности, основы ее духовной жизни, интимно сущностного пласта психики. Важность изучения эмоциональной сферы человека обусловлена поиском закономерностей в онтогенезе человеческой психики, нахождением внутренних связей и элементов, степени их зависимости и влияния на другие сферы жизни человека и в целом созданием концепции психического развития. Одним словом, изучение эмоциональной сферы человека является не только теоретически, но и практически важным направлением исследований.

Прагматизация современного общества и приоритет когнитивной сферы обусловливают некоторый упадок исследований эмоций человека. В то же время признается значение эмоциональности в становлении личности в детском и подростковом возрастах. Исследование эмоциональной сферы подростков признается исключительно важной областью исследования, поскольку становление и развитие личности в данном возрасте определяет успешность ее дальнейшей социализации во взрослой жизни, вхождения в профессиональную деятельность, а также умение справляться с различными профессиональными и личностными проблемами и сохранять эмоциональную стабильность [11].

Говоря об организации практической работы с подростками в целях развития их эмоциональной сферы, отметим, что наиболее остро стоит вопрос разработки методических подходов, позволяющих не только решить насущные эмоциональные проблемы подростка, уберегая его от перспективы попасть в сложные ситуации, но и обучить его навыкам психологической помощи самому себе в будущем, помочь выйти из подросткового возраста уже эмоционально зрелой личностью. Одним из таких способов является занятие эстрадным вокалом $[3 ; 6 ; 7 ; 12 ;$ 16]. Музыка в целом и эстрадная музыка в частности оказывает определенное влияние на эмоциональную сферу человека. Разные жанры эстрадной музыки могут воодушевлять слушателя, улучшать его эмоциональное состояние - правильно подобранная музыка помогает преодолевать сложности, настраиваться на рабочий лад, чувствовать позитивный настрой.

Методы и методология исследования базируются на психолого-педагогической литературе. В контексте общей психологии проблематику психологии подростка изучали А. Алексеев, Р. Аткинсон, Е. Белинская, В. Бехтерев, М. Вершинин, Л. Выготский, И. Кон, Д. Майерс, И. Назарова, Л. Стевенсон, Е. Сушко, О. Тихомандрицкая, 3. Фрейд, Д. Хаберман, В. Черпаков, К. Юнг и др. Вопросам педагогической психологии уделяли внимание такие авторы, как Н. Бордовская, Т.В. Габай, М. Гамезо, Н.С. Дашина, И. Дубровина, Д. Дьюи, В. Зацепин, Н. Калинина, Н. Клюева, В. Крысько, Л. Орлова, Е. Петрова, А. Прихожан, А. Радугин, А. Реан, С. Розум, Н. Талызина, И.А. Трофимова, В. Шепель и др.

Разработкой вопросов проблемных подростков, их социализации и адаптации занимались Л. Агеева, А Айхорн, К. Анна, Н. Гавриленко, Л.А. Григорович, А.Ю. Егоров, О. Истратова, М. Кле, М.Ю. Кондратьев, Л. Кругляк, Ю. Можгинский, А. Некрасов, Г. Ньюфелд, Г. Паренс, В. Рерке, А. Яценко и др. Работы А. Грецова, А.И. Дедушки, А.Г. Лидерса посвящены вопросам практической индивидуальной и коллективной работы с подростками.

Результаты. Эмоциональная сфера личности включает в себя широкий спектр переживаний и чувств человека. Любое переживание является оценкой процесса удовлетворения потребностей человека. Чувства предстают как оценка возможности конкретного объекта удовлетворить эту потребность индивида.

Пристальное внимание психологов и педагогов к подростковому возрасту в плане развития эмоциональной сферы объясняется не только и не столько насыщенностью проявления подростком эмоций, а влиянием на формирование устойчивых реакций, будущих способов адаптации к новой взрослой жизни. Впрочем, неустойчивость эмоциональной сферы подростка, как часто демонстрировалось, прямо влияет на успеваемость в школе, состояние здоровья, его физическое состояние. Другими словами, работать с эмоциональной сферой подростка необходимо, во-первых, потому что это позволит стабилизировать его в настоящее время, помочь разрешать возникающие перед ним задачи и проблемы, повысить его 
успеваемость, улучшить физическое состояние, снизить заболеваемость, а во-вторых, потому что это обеспечит ему возможности сформироваться во взрослого с устойчивой психикой, успешно адаптирующегося в меняющемся мире, сохраняющего в любых условиях положительный настрой.

Эмоциональную сферу учеников подросткового возраста характеризуют следующие эмоциональные проявления:

1) подросток чрезвычайно эмоционально возбудим, он вспыльчив, моментально втягивается в интересное для него дело и может быстро его забросить ввиду исчезновения интереса, он жарко отстаивает правоту и резко реагирует на несправедливость по отношению к нему или близким, имеет свое мнение и активно доказывает его, невзирая на авторитеты;

2) в подростковом возрасте эмоциональные переживания уже отличаются от детских они более глубокие и устойчивые, а ввиду сильной обидчивости подросток может долго помнить свое негативное чувство;

3) отсутствие критичности на фоне высокой тревожности и постоянное переживание страха ведет к тяжелым психологическим состояниям. Это обусловлено развитием личностно-интимной сферы молодого человека, складыванием романтических отношений и переживаний по поводу своей состоятельности в таких отношениях (девушки бояться оказаться некрасивыми, молодые люди - попасть в нелепую ситуацию; все они переживают из-за пристального внимания к себе со стороны окружающих и бояться быть осмеянными);

4) сложность переживаемых чувств и эмоций, отсутствие навыков контроля эмоциональной сферы ведут к противоречиям; так, подросток может защищать своего товарища, понимая при этом, что товарищ виноват и его ругают за дело, либо в связи с повышенной чувствительностью и представлениями о собственном достоинстве подросток может расплакаться, понимая при этом, что слезы не адекватная реакция на ситуацию;

5) в связи с ростом самосознания, активизацией рефлексии подросток начинает переживать не только относительно собственной оценки со стороны окружающих, но так же критически относится к себе сам, причем в такой оценке отсутствует объективность, но сохраняется высокая доля негативных оценок;

6) в подростковом возрасте возрастает тяга к группе, отношениям с близкими по духу людьми, разделяющими интересы, взгляды; подростки сбиваются в группы и испытывают сильную зависимость от одобрения членов коллектива: для них становится важнее мнение приятелей, чем негативная оценка взрослых, которые в этот период теряют авторитет; страх быть отвергнутым группой настолько силен, что подросток готов идти на опрометчивые, опасные для окружающих, а также для его жизни и здоровья поступки;

7) дружба в подростковом возрасте отличается от дружбы в детстве основой и сроком; подростков связывают не общая игра или общественно полезная деятельность (если ее специально не организовали взрослые), а интересы и взгляды; подростки могут дружить группами, такая связь может быть достаточно продолжительной;

8) у подростков как никогда сильно развито чувство патриотизма, они готовы его не только декларировать, но и физически отстаивать.

Большим потенциалом в развитии эмоциональной сферы личности обладает и эстрадная музыка, объединяющая в себе множество разнообразнейших стилей и направлений на любой вкус $[1 ; 4 ; 5 ; 8 ; 9 ; 13 ; 15 ; 18]$. Нельзя не упомянуть легкий рок, например рок-балладу, которая настраивает слушателя на романтический лад, повышает энергию человека и отвечает запросам подростка на возникшие новые для него чувства. Композиции на стыке рока и фолка также положительно влияют на психику человека благодаря используемым в таких композициях звукам арфы, скрипки и разных народных инструментов. Однако среди стилей эстрадной музыки есть и негативно воздействующие на психику подростка, поэтому необходимо отслеживать музыкальный контент слушателя подросткового возраста и тщательно подбирать репертуар учащегося-вокалиста $[10 ; 12 ; 16]$. 
Легкая популярная музыка с содержательным текстом, смысл которого направлен на совершенствование личности, стимулирование развития ее сильных сторон, окажет положительное влияние на человека, сподвигнет его к активной деятельности, творчеству, взаимодействию с окружающими людьми. Бессмысленные же композиции с низким качеством исполнения оглупляют человека, низводят его на примитивный уровень. Следует учитывать, что монотонные однообразные ритмы ухудшают память и внимание, повышают рассеянность, снижают настроение и общее психоэмоциональное состояние подростков.

Благотворно влияет на эмоциональное состояние человека народная музыка, которая уходит своими корнями вглубь веков, имеет глубинные смыслы и тесно связана с физиологией человека и его душевным состоянием. А вот рэп и хип-хоп, с одной стороны, могут повышать коммуникабельность и активность человека, а с другой - способствовать росту агрессии, злобы, стремления к разрушению и вандализму. В целом такая музыка не способствует благотворному влиянию на психоэмоциональное состояние человека, и, несмотря на то что она может на короткий промежуток времени улучшить настроение, регулярное и частое прослушивание такой музыки влияет на психику человека негативно.

Такие направления, как джаз, блюз, регги, минимализм [18], оказывают благотворное влияние на мозговую деятельность и психику человека. Во время исполнения быстрых композиций у слушателей учащается пульс, усиливается кровообращение, во время медленных стабилизируется давление. Рассматриваемые жанры развивают творческое начало человека, усиливают его активность, креативность, способность решать различные жизненные задачи, что так важно для подростков, которые учатся взрослой жизни [20].

В настоящее время проводятся различные исследования относительно влияния разных жанров эстрадной музыки на психоэмоциональное состояние человека. Доказано, что оптимальное влияние на психику, физическое и умственное состояние человека оказывает классическая музыка, которая способна улучшить настроение, избавить от депрессии, успокоить нервную систему после стресса. В отношении других жанров музыки существуют ограничения относительно громкости и частоты ее прослушивания, поскольку многие жанры эстрадной музыки, прежде всего тяжелый рок, металл, низкопробная популярная музыка, рэп, хипхоп, оказывают крайне негативное влияние на эмоциональную сферу слушателя, усугубляя его негативные состояния либо вообще заменяя позитивный настрой на негативный.

В таких условиях очевидна важность тщательного подбора музыкальных жанров и композиций, прослушиваемых подростками, эмоциональное состояние которых крайне не стабильно и уязвимо. Процесс обучения и вокального воспитания подростков в определенной степени схож с процессом обучения взрослых, однако имеет определенную специфику, связанную не только с физиологическими изменениями тела подростка (изменение строения голосового аппарата, мутация голоса), но и с эмоциональным состоянием обучающегося, необходимостью учета данной стороны личности подростка.

0бсуждение. Педагоги разрабатывают различные подходы и методы для обучения вокалу на основе, в том числе, развития эмоциональной составляющей подростка. При первых встречах педагог создает условия для осознания подростком себя как личности, осознания наличия уникальных физических и человеческих качеств [20]. Педагог обращает внимание на важность индивидуальных свойств личности ученика и необходимость их развивать не только в контексте личностного роста, но и с точки зрения профессиональной вокальной деятельности [17].

На пути к овладению навыками управления эмоциями могут быть использованы методы самовнушения, настрой на определенное состояние. Так, подросток учится видеть свое «Я», свои лучшие качества - он учится воспринимать свою уникальную индивидуальность, чтобы впоследствии реализовать ее. Со стороны педагога в этом процессе необходимо всяческое поощрение стараний ученика, похвала его достижений, демонстрация будущих возможностей и перспектив, к которым ученик должен стремиться и которые он может достигнуть при определенном вложении сил и стараний. 
Во время занятий вокалом у подростка могут возникать мышечные зажимы, которые напрямую происходят из его эмоционального состояния. Мышечные зажимы мешают полноценно раскрыться ученику, работать спокойно и уверенно. Первоначально педагог сам работает с мышечными зажимами, снимает их, но важно также учить самого ученика работать со своим эмоциональным состоянием, которое отражается в физическом теле. Для снятия зажимов помогают следующие установки: «Прояви всё лучшее, что есть в тебе», «Представь, что твой голос и есть ты сам, а твое "Я" - прекрасно и удивительно»; «Дари свой голос с любовью и радостью, от всей души, испытывая при этом возвышенный внутренний полет». Так педагог расслабляет ученика, настраивает на продуктивную работу, помогает ему улучшить настроение, раскрыть в себе те качества и сильные стороны, которые помогут как в учебе, так и в обычной жизни.

Педагог должен объяснить и передать ученику, что его внутреннее состояние полностью отражается в голосе, и если он волнуется, находится в состоянии депрессии, переживает, то ни о каком высоком звучании не может быть и речи. Процесс фонации должен происходить радостно, одухотворенно. Очевидно, что любое значимое событие сопровождается определенными переживаниями, волнением, но настроиться на работу голосом и полностью раскрыть его можно только в том случае, если переживания будут радостными, если волнение раскрывается положительно, счастливо. Только в таком положительном настроении вокалист может освободиться и подарить слушателям голос, идущий от сердца.

Вокалист должен настроиться на работу с голосом: голос - это внутренний инструмент певца. Управляя своим голосом, подросток учится одновременно проводить слуховой самоконтроль, совмещая его с эмоциональным началом. Одно без другого не даст нужного результата. Раскрывая и высвобождая голос, вокалист позволяет ему звучат полно, свободно, эмоционально. Во время уроков вокалу подросток учится слышать и слушать себя под руководством педагога, а впоследствии это становится профессиональной привычкой певца.

Важным методом работы с эмоциональной составляющей подростка является осознание им голоса как средства самовыражения. Для этого применяется аутогенная тренировка следующего содержания: «Я пою - значит, творю, созидаю», «Мой голос - отражение моей души», «Я пою с любовью и радостью». Ученик раскрывает себя как личность через голос, он делает шаг навстречу к самому себе. Если изначально он учился воспринимать голос как дар, как уникальное свойство личности, то теперь он учится сливаться с голосом, воспринимать его как неотъемлемую часть себя, которая позволяет ему творить, выражать свою личность, свое естество.

Одновременно подросток учится рассматривать голос и звуки, им издаваемые, как нечто отдельное и самостоятельное, анализировать их, он должен понять, что красота звука может быть рождена только в любви, положительном настрое - только таким звуком будут любоваться. А это может произойти только при том условии, что внутри у вокалиста свобода и радость: только в радостном творческом начале могут родиться прекрасные звуки. Таким образом, внутренний мир певца изливается наружу.

Технология рождения голоса через эмоциональный настрой заключается в том, чтобы войти в себя, почувствовать свое хорошее настроение, свой талант, свою красоту, найти свой тембр, почувствовать его, наполнить его добром и любовью, после чего излить этот голос наружу, в мир, как подарок слушателям, выражение себя, своих глубинных чувств и переживаний. Вокалиста можно сравнить с сосудом, однако он должен взращивать в себе положительный настрой и смотреть на мир с любовью, чтобы этими чувствами делиться с окружающими.

Вокалист должен осмыслить, прочувствовать заложенное композитором настроение и определить, каким образом он передаст этот настрой слушателям, как ему следует настроить себя, чтобы максимально точно передать, не исказив, смысл произведения. В работе над эмоциональной составляющей личности педагог работает над снятием и устранением 
психологических зажимов и барьеров. Самыми распространенными негативными эмоциями являются страх перед выступлением, волнение, переходящее в панику, стыд, стресс и т.д. Если вокалист не сможет справиться над своими негативными эмоциями, они не дадут ему расти и развиваться, он не сможет освободиться от зажимов и останется на том уровне, на котором пришел в музыкальную школу. Очевидно, что есть множество певцов, которые так и не смогли справиться со своими эмоциями, не смогли преодолеть барьеры и комплексы, педагоги не нашли к ним подход и соответствующую методику, чтобы развить психическую составляющую вокалиста.

В работе над любым произведением в основу должна быть положена одухотворенность, поскольку именно она, а не средства музыкальной выразительности создает музыкальный образ. Вот почему так важно работать над эмоциональной сферой вокалиста, устранять негативные эмоции, менять их на положительный взгляд на жизнь, поскольку именно в таком случае возможно выражение внутреннего мира певца, его раскрытие и демонстрация.

Таким образом, занятия вокалом включают в себя не только работу с артикуляцией, дикцией, дыханием и другими аспектами певческого мастерства, но и в значительной степени работу с эмоциональной сферой вокалиста. Снятие психологических зажимов, развитие навыка устранения негативных эмоций, развитие чувства собственной значимости, самосознания, умение рефлексировать, причем познавать не только собственную личность, но и отдельные свои качества и свойства, как в отдельности от себя, так и в качестве инструмента собственного выражения, раскрытия внутреннего мира, - все эти методики изначально направлены на раскрытие певческого таланта вокалиста, становление его как профессионального певца, однако параллельно они оказывают колоссальный терапевтический эффект в остальных сферах жизни подростка $[14 ; 19]$.

Выводы. Психологические проблемы могут возникнуть в любом возрасте, но этап подросткового развития является крайне важным с точки зрения научения работать с ними, выявлять свой потенциал, преодолевать свои слабости, возвышаться над ними. Без обретения свободы творчества не может состояться настоящий вокалист; умение использовать свой голос только на основе технических средств оставляет певца на уровне ремесленника, но никак не художника. Для раскрытия себя, обретения свободы могут понадобиться годы поиска: вокалист ищет педагога, репетитора, ищет технологии, ищет себя в творчестве. Это долгий и сложный процесс, но его результат приносит не только радость творчества самому вокалисту, но и красоту пения для слушателей.

Опытный педагог контролирует творческую жизнь своего ученика и внимательно следит за другими аспектами его жизни, поскольку со всей ясностью понимает: сложности и проблемы в других сферах жизни вокалиста рано или поздно отразятся на его творчестве. Поэтому задачи педагога - построить близкие доверительные отношения с учеником, формировать его вкусовые предпочтения, привычки, взгляды. Под чутким руководством педагога подросток меняется внешне и внутренне, меняется его окружение, он излучает вокруг себя особую ауру.

Богатство внутреннего мира составляет красоту творчества, поэтому педагог должен деликатно раскрыть его, найти самые прекрасные качества и черты ученика, обогатить их своим опытом, научить вокалиста управлять и взращивать эти способности, после чего можно явить их миру. Именно на этом должна основываться вокальная педагогика. Если вокалист найдет путь к себе, он получит доступ к неисчерпаемому источнику вдохновения и творческих возможностей. В будущем это даст ему возможность находить силы для передачи мысленных и эмоциональных импульсов, изображения мельчайших изменений настроения. Такое творчество дарит радость как исполнителю, так и слушателю.

В результате эмоциональной стабилизации на уроках вокала подросток становится более спокойным, уравновешенным, повышается его самооценка, он не зависит от внешнего одобрения, а ищет источник вдохновения и душевные силы внутри себя, что делает его 
стабильным с психологической точки зрения. Всё это обеспечивает формирование навыков эмоционально-выразительного музыкального исполнения, художественного мышления, развитие способности к музыкально-образным представлениям, творческого воображения и фантазии, наконец, глубокое проникновение в содержание песни и поиск адекватной ему формы сценического решения. Теоретические и практические занятия эстрадным вокалом позволяют расширить спектр эмоционального восприятия подростков, обогащают их эмоции, повышают уровень восприятия сложных музыкальных произведений и в целом развивают их эмоциональную сферу.

\section{Список литературы}

1. Бондаренко В., Дроздов Ю. Энциклопедия популярной музыки. Минск: Экономпресс, 2006. $479 \mathrm{c.}$

2. Добровольская Н.Н., Орлова Н.Д. Что надо знать о детском голосе. М.: Музыка, 2000. $146 \mathrm{c}$.

3. Исаева И. Эстрадное пение. М.: Владос, 2005. 203 с.

4. История и развитие хип-хоп культуры: сб. / сост. С.Н. Возжаев, А.В. Максимов, Ю.К. Ярушников; предисл. В.А. Лукова. М.: Логос, 2004. 149 С.

5. Козлов А. Рок-музыка: истоки и развитие. М.: Знание, 1990.56 с.

6. Кольман В.Ф. Значение дополнительного музыкального образования в формировании личности человека // Методология и история психологии. 2010. № 4. С. 35-40.

7. Малинин Е.М. Вокальное воспитание детей. М.: Музыка, 1998. 206 с.

8. Мешкова А., Коробова А. Массовая музыкальная культура XX века. Екатеринбург: УгК, $2004.99 \mathrm{c}$.

9. Музыка наших дней: современная энциклопедия / ред. Д. Володихин. М.: Аванта +, 2002. $430 \mathrm{c.}$

10. Мурзич А.О. Практические рекомендации по работе с начинающими вокалистами. Минск, 1998. 57 C.

11. Мухина В.С. Возрастная психология: феноменология развития, детство, отрочество. М.: Академия, 2004. 145 с.

12. Огородников Д.Е. Музыкально-певческое воспитание детей в общеобразовательной школе: метод. пособие. Л.: Музыка, 1972. 69 с.

13. Орлова И. В ритме новых поколений (молодежные музыкальные жанры в общей системе современной музыкальной культуры). М.: Знание, 1988. 54 с.

14. Переверзева М.В. и др. Музыкотерапия и ее значение в обучении детей с ОВЗ / Царев Д.В., Переверзева М.В., Илларионова Н.Н., Ющенко Н.С., Давыдова А.А., Трифанова В.П., Щербинина В.М., Цилинко А.П. Музыкально-исполнительское искусство: история, теория, практика: коллективная монография. М.: РГСУ, 2019. С. 38-54.

15. Провозина Н. История джазовой и эстрадной музыки. Ханты-Мансийск: ЮГУ, 2004. 69 с.

16. Рокитянская Т.А. Воспитание звуком. Ярославль: Академия развития, 2002. 102 с.

17. Anufrieva N., Avramkova I., Korsakova I., Pereverzeva M.V., Shcherbakova A. Orientation of musical disciplines as a condition for the formation of competencies // Opcion. 2018. No. 34 (Special Issue 17). P. 719-730.

18. Davydova A.A, Lushnikov S.S, Pereverzeva M.V., Smirnov A.V., Tsarev D.V. Piano music of composers-minimalists in the teaching repertoire of higher music education // Opcion. 2018. No. 34 (Special Issue 17). P. 149-162.

19. Davydova A.A., Pereverzeva M.V., Tsarev D.V., Shcherbakova A.I., Shcherbinina V.M. Musical Art-Therapeutic Technologies of Overcoming Psychological Problems and Developing the Emotional Perception of Children // Journal of Pharmaceutical Sciences and Research. 2018. Vol. 10 (4). P. 846-848.

20. Shafazhinskaya N.E., Shcherbinina V.M., Ivanova E.Y., Belyakova T.E., Pereverzeva M.V. Learning about world art culture as a method of forming a universal cross-cultural communication competence // Humanities \& Social Sciences Reviews. Vol. 7. 2019. No. 6. P. 1225-1229.

\section{References}

1. Bondarenko V., Drozdov Yu. Enciklopediya populyarnoj muzyki. Minsk: Ekonompress, 2006. $479 \mathrm{~s}$.

2. Dobrovol'skaya N.N., Orlova N.D. Chto nado znat' o detskom golose. M.: Muzyka, 2000. $146 \mathrm{~s}$. 
3. Isaeva I. Estradnoe penie. M.: Vlados, 2005. $203 \mathrm{~s}$.

4. Istoriya i razvitie khip-khop kul'tury: sb. / sost. S.N. Vozzhaev, A.V. Maksimov, Yu.K. Yarushnikov; predisl. V.A. Lukova. M.: Logos, 2004. 149 s.

5. Kozlov A. Rok-muzyka: istoki i razvitie. M.: Znanie, $1990.56 \mathrm{~s}$.

6. Kol'man V.F. Znachenie dopolnitel'nogo muzykal'nogo obrazovaniya $v$ formirovanii lichnosti cheloveka // Metodologiya i istoriya psikhologii. 2010. № 4. S. 35-40.

7. Malinin E.M. Vokal'noe vospitanie detej. M.: Muzyka, 1998. $206 \mathrm{~s}$.

8. Meshkova A., Korobova A. Massovaya muzykal'naya kul'tura XX veka. Ekaterinburg: UGK, 2004. $99 \mathrm{~s}$.

9. Muzyka nashikh dnej: sovremennaya enciklopediya / red. D. Volodikhin. M.: Avanta,+ 2002. $430 \mathrm{~s}$.

10. Murzich A.0. Prakticheskie rekomendacii po rabote s nachinayushchimi vokalistami. Minsk, $1998.57 \mathrm{~s}$.

11. Mukhina V.S. Vozrastnaya psikhologiya: fenomenologiya razvitiya, detstvo, otrochestvo. M.: Akademiya, 2004. $145 \mathrm{~s}$.

12. Ogorodnikov D.E. Muzykal'no-pevcheskoe vospitanie detej v obshcheobrazovatel'noj shkole: metod. posobie. L.: Muzyka, 1972. $69 \mathrm{~s}$.

13. Orlova I. V ritme novykh pokolenij (molodezhnye muzykal'nye zhanry $v$ obshchej sisteme sovremennoj muzykal'noj kul'tury). M.: Znanie, 1988. $54 \mathrm{~s}$.

14. Pereverzeva M.V. i dr. Muzykoterapiya i ee znachenie v obuchenii detej s OVZ / Carev D.V., Pereverzeva M.V., Illarionova N.N., Yushchenko N.S., Davydova A.A., Trifanova V.P., Shcherbinina V.M., Cilinko A.P. Muzykal'no-ispolnitel'skoe iskusstvo: istoriya, teoriya, praktika: kollektivnaja monografiya. M.: RGSU, 2019. S. 38-54.

15. Provozina N. Istoriya dzhazovoj i estradnoj muzyki. Khanty-Mansijsk: YuGU, 2004. $69 \mathrm{~s}$.

16. Rokityanskaya T.A. Vospitanie zvukom. Yaroslavl': Akademiya razvitiya, 2002. $102 \mathrm{~s}$.

17. Anufrieva N., Avramkova I., Korsakova I., Pereverzeva M.V., Shcherbakova A. Orientation of musical disciplines as a condition for the formation of competencies // Opcion. 2018. No. 34 (Special Issue 17). P. 719-730.

18. Davydova A.A, Lushnikov S.S, Pereverzeva M.V., Smirnov A.V., Tsarev D.V. Piano music of composers-minimalists in the teaching repertoire of higher music education // Opcion. 2018. No. 34 (Special Issue 17). P. 149-162.

19. Davydova A.A., Pereverzeva M.V., Tsarev D.V., Shcherbakova A.I., Shcherbinina V.M. Musical Art-Therapeutic Technologies of Overcoming Psychological Problems and Developing the Emotional Perception of Children // Journal of Pharmaceutical Sciences and Research. 2018. Vol. 10 (4). P. 846-848.

20. Shafazhinskaya N.E., Shcherbinina V.M., Ivanova E.Y., Belyakova T.E., Pereverzeva M.V. Learning about world art culture as a method of forming a universal cross-cultural communication competence // Humanities \& Social Sciences Reviews. Vol. 7. 2019. No. 6. P. 1225-1229.

\section{Библиографическое описание статьи / Reference to article}

Переверзева М.В., Габдиев М. Специфика развития эмоциональной сферы подростков на занятиях эстрадным вокалом // Ученые записки Российского государственного социального университета. T. 19. 2020. № 1 (154). C. 152-159. DOI: 10.17922/2071-5323-202019-1-152-159 (Библиографическое описание согласно российским стандартам).

Pereverzeva M.V., Gabdiev M. Specifika razvitiya emocional'noj sfery podrostkov na zanyatiyakh estradnym vokalom // Uchenye zapiski Rossijskogo gosudarstvennogo social'nogo universiteta. T. 19. 2020. № 1 (154). S. 152-159. D0I: 10.17922/2071-53232020-19-1-152-159 (Reference in Roman script).

Pereverzeva, M.V. \& Gabdiyev, M. (2020) Specifics of Development of Teenagers' Emotional Sphere in Classes with Variety Vocal, Scientific Notes of Russian State Social University. Vol. 19. No. 1 (154). P. 152-159. DOI: 10.17922/2071-5323-2020-19-1-152-159 (International bibliographic description). 


\title{
Е.А. Мелешкина,
}

канд. пед. наук, доцент кафедры социологии и философии культуры,

Российский государственный социальный университет, Москва.

E.A. Meleshkina,

candidate of pedagogical sciences, associate professor of the department

of sociology and philosophy of culture, Russian State Social University, Moscow.

E-mail:el.mel@mail.ru

\section{А.В. Жилина,}

канд. пед. наук, доцент кафедры эстрадно-джазового искусства,

Московский педагогический государственный университет, Москва.

A.V. Zhilina,

candidate of pedagogical sciences, associate professor of the department

of variety and jazz art, Moscow Pedagogical State University, Moscow.

E-mail: zhavka@mail.ru

\section{Семантические доминанты русского музыкального авангарда в курсе музыкально-исторических дисциплин вузов}

\author{
Semantic Dominants of Russian Musical Vanguard in the Course \\ of Musical and Historical Disciplines of Higher Education Institutions
}

Дата поступления

20.12.2019
Дата препринта

28.02.2020
Дата публикации

30.03.2020

Аннотация: русская музыка второй половины XX века, отразившая драматические события столетия, динамику современной жизни, мысли и чувства людей того времени, характеризуется преобладанием конфликтно-трагических и лирико-философских тем и образов, рассматриваемых и оцениваемых с точки зрения духовно-нравственных принципов общества. Однако в педагогической практике именно авангардной музыке, наиболее сложной по содержанию и интерпретации, отдается место по остаточному принципу - как правило, в самом последнем семестре в курсе музыкально-теоретических или исторических дисциплин. Кроме того, не уделяется должного внимания методике познания и практического освоения авангардной музыки, изучения ее семантики и музыкального языка. А между тем в музыкознании успешно применяются методы герменевтического, семантического и интертекстуального анализа, практическому применению которых посвящена данная работа.

Annotation: Russian music of the second half of the $X X^{\text {th }}$ century, reflecting the dramatic events of the century, the dynamics of modern life, thoughts and feelings of people of that time, is characterized by the prevalence of conflict-tragic and lyrical and philosophical themes and images considered and evaluated from the point of view of spiritual and moral principles of society. However, in pedagogical practice, there is given a place on the residual principle - as a rule, in the most recent semester, in the course of musicaltheoretical or historical disciplines - to avant-garde music, the most complex in content and interpretation. In addition, due attention is not paid to the methodology of knowledge and practical mastery of avant-garde music, the study of its semantics and musical language. Meanwhile, musicology successfully uses methods of hermeneutic, semantic and intertextual analysis, the practical application of which is devoted to this work.

Ключевые слова: музыка, семантика, авангард, русская музыка XX века, средства выразительности. 
Key words: music, semantics, vanguard, Russian music of the $X X^{\text {th }}$ century, means of expressiveness.

Введение. Несколько вех в истории XX века - социально-политических и музыкальнотворческих - были отмечены сменами морально-этических норм в обществе и художественно-эстетических ориентиров в искусстве. Отсюда - мощное возрождение к жизни исконных национально-художественных традиций вплоть до ранних пластов мифологии, древних притч, первозданных типов интонирования и музицирования, семантики звучания народных инструментов. Исконные русские музыкальные традиции становятся одной из главных семантических доминант авангардного искусства второй половины XX века. Все эти особенности русской музыки периода авангарда и постмодернизма должны стать частью содержания программ подготовки музыкантов-исполнителей и педагогов-музыкантов в колледжах и вузах [20].

Мощный подъем в музыкально-исполнительском и композиторском творчестве был связан и с идеологической «оттепелью» постсоветского периода, и с активизацией концертной деятельности в стране, и с укреплением международных связей, отношений и взаимодействий между русскими и зарубежными деятелями искусства, но главное - с возвращением к сокровищам национального художественного наследия, возрождением интереса к вечным общечеловеческим ценностям и отечественной культуре, поиском новых духовно-нравственных констант Новейшего времени [8]. Этот поиск был вызван неверием, разочарованием, пессимизмом, которыми было охвачено советское общество во второй половине XX века.

В искусстве нашло отражение негативное мироощущение: «0бразы распадающегося мира, “конца света" заполняют многие сочинения (А. Шнитке, С. Губайдулина, С. Слонимский). Апокалипсические ситуации проявляются не только в природных катаклизмах, в пожаре гражданских войн, но и в ощущении дисгармонии людей и с собой, и с окружающими (народ стал ощущать себя как скопище одиночек, живущих лишь в один исторический период)» [2, с. 8]. Всё это заставило людей искать новую духовную опору, возвращаться в лоно общечеловеческих ценностей, затрагивать вечные проблемы и сюжеты в направлении от смерти к жизни и бессмертию. Главной тенденцией в истории русской авангардной музыки второй половины прошлого столетия стал духовно-нравственный ренессанс, глубоко прочувствованный художниками и нашедший отражение во всех видах искусства России [9, с. 5].

При всей множественности индивидуальных стилей, техник письма и эстетических принципов композиторов-авангардистов (Э. Денисов, Р. Щедрин, А. Эшпай, А. Шнитке, Б. Чайковский, С. Губайдулина, Б. Тищенко) и «традиционалистов» (последователей направлений в духе «нео-» - Г. Свиридов, Г. Уствольская, Т. Хренников, В. Гаврилин, Ю. Буцко и др.) объединяет общее семантическое поле, связанное с духовно-нравственными проблемами современности. Отсюда - преобладание лирико-философского типа самовыражения, исповедальность, рефлексия, ностальгия, проникновенность высказывания [3]. Недаром «с середины 80-х годов наблюдается, причем у композиторов самых разных направлений, очередной этап осознания глубинной роли традиций именно для современной культуры» [2, с. 17].

Методы и методология. Методами исследования семантики произведений русских композиторов служат слуховой и текстовый анализ партитур, очерков музыковедов-историков и теоретиков, интертекстуальный анализ философских и литературных источников, произведений живописи и других видов искусства, сравнение типовых и нетиповых образно-эмоциональных средств выразительности, применяемых композиторами XX столетия.

Ввиду широты рассматриваемого вопроса в работе применен комплексный метод исследования, сочетающий культурологический, исторический и теоретический подходы к изучаемому материалу. Любопытными представляются также комментарии авторов и исполнителей музыки, принадлежащие теоретикам и практикам авангардной композиции, в которых также содержится информация, свидетельствующая о семантике музыкального материала, связанного с теми или иными образами или переживаниями. Кроме того, применяется ана- 
лиз педагогической практики, в частности освоения семантики произведений русских композиторов второй половины XX века в курсах музыкально-исторических и теоретических дисциплин.

Результаты. Во второй половине столетия по-новому обозначилась тема «национальной русской музыки» и актуализировался интерес к фольклору, коренным чертам культуры, духовному наследию народа в целом. Возродился интерес композиторов к эпико-трагедийному и психологическому фольклору в жанрах плача, архаической псалмодии, знаменному распеву, древним духовным обрядам. Присутствие национальных элементов в музыке представлялось перспективным для дальнейшего развития искусства. В неофольклоризме (Г. Свиридов, Р. Щедрин, В. Гаврилин, С. Слонимский, Б. Тищенко) подчеркивалась неизменная ценность традиций, проявлялась тяга к духовности, усилению личностного начала. Опосредованно обращались к фольклору и авангардисты А. Шнитке, Э. Денисов, С. Губайдулина. Правда, они «переосмысливали» фольклор, представляя его в контексте новейших композиционных средств, более широких жанрово-стилистических рамок [19]. В новом освещении предстают символы Древней Руси, богатыри и выдающиеся исторические личности (балет «Ярославна» Б. Тищенко, симфония-сюита «Древнерусская живопись» Ю. Буцко, опера «Петр I» А. Петрова, концерт-картины для симфонического оркестра и солирующего квинтета духовых инструментов «Андрей Рублев» К. Волкова и др.). Как справедливо заметил А. Солженицын, «русская культура - явление своеобычное, лицом и душой неповторимое. И не пристало нам обреченной отдаваться потере своего лица, понять дух своей долгой истории: мы больше можем потерять дорогого своего, чем приобрести чужого взамен» [13, c. 204].

Духовная тема в музыкальной культуре, свидетельствующая о пробуждении национального самосознания и возрождении вечных национальных ценностей, проявилась в круге образов и тем музыкальных произведений, среди которых стали преобладать религиознофилософские, духовно-нравственные, морально-этические и художественно-эстетические концепции [12]. Новое, трепетное отношение сформировалось к религии как важнейшей части национального наследия. Появляется целый ряд духовных сочинений (Е. Голубев, Н. Каретников, А. Эшпай и др.) и композиций религиозной тематики, в которых «выявляются две направленности: духовность русского православия и духовность христианства как общечеловеческого универсума» [2, с. 21]. Эту линию композиторского творчества вели Г. Свиридов, Р. Леденёв, Э. Денисов, Н. Каретников, Н. Сидельников, Г. Дмитриев. Примечательно, что тема христианской духовности в общечеловеческом масштабе широко представлена в творчестве русских авангардистов А. Шнитке (Четвертая симфония-ритуал, объединившая традиции католицизма, лютеранства, православия, иудаизма), С. Губайдулиной («Семь слов Христа Спасителя», «0фферторий»), Г. Уствольской («Dies Irae»), В. Артёмова, П. Караманова и Э. Денисова (каждый из них создал Реквием). Обратимся к некоторым сочинениям авангардистов и определим их духовно-нравственные доминанты.

В Четвертой симфонии (1984) А. Шнитке перед нами предстает «чистый лик добра», «ненапряженное музыкальное созерцание» [17, с. 204]. Жанром для своей симфонии автор выбрал ритуал - духовное действо, направленное на общение с Всевышним, единение с миром, размышление о добре, святости, добродетели. В музыке преобладают однородное развертывание материала, длительные растворения звучания, медленные темпы, статика и угасание. Так композитор воплощает образы возвышенности, страдания, тернистого пути к истине, созерцания, духовного поиска, размышлений о «горнем мире» [14]. Отсюда и форма вариаций, в которых светлый и сдержанный характер звучания сменяется скорбным, а затем - радостным славлением. Тем самым описывается круг мыслей о Христе, прошедшем земной и небесный пути ради спасения человечества. Есть в партитуре и символические «колокольные звоны», и каноны, и мотивы круга и креста, и музыкально-риторические фигуры. В коде Шнитке воспроизводит «тот образ торжественности, возвышенности, радостности, света, красоты, 
благоговейности, который сформировала и много веков культивировала европейская профессиональная музыка в храмах, дворцах и в концертных залах... Это и есть тот воплощенный в звуках высокоэтический лик блага и добра» [17, с. 209].

«Реквием» (1975) Шнитке написал на канонический текст, однако решил этот жанр неожиданно и потрясающе. Музыкальный язык произведения естественен и прост, порой архаичен (выделена одноголосная мелодия, лад диатоничен, четкая тональная опора), что оказывает таинственный, магический эффект. Драматургия «Реквиема» «создает чрезвычайно яркий смысловой эффект: атмосфера трагического одиночества внезапно взрывается мощным голосом духовного самоутверждения, и раскрываются иные горизонты. Так в этом произведении... возникает тема преодоления смерти» [17, с. 112]. Композитор реализует главную функцию религиозного жанра - очищение души человека, воссоединение его с Всевышним, дарование надежды на спасение. «Шнитке тяготеет к запечатлению остро трагедийной образности. Процессам деструкции, неотвратимого разрушения противостоят символы духовной Красоты и Вечности. Однако восхождение к ним воплощается не преодолением натиска злых сил, а резким, порой непредсказуемыми поворотами в контрактную сферу изначально позитивных или нейтральных образов» [9, с. 63-64].

В другом сочинении - Первой симфонии (1972) - Шнитке выстраивает смысловое развитие на движении от «антисимфонии» части I (деструктивных сил хаоса) к «симфонии» в финале цикла (продуктивным силам гармонии). В произведении сталкиваются темы хаоса, символизирующие отрицательную образность, и темы порядка, ассоциирующиеся с положительной образностью. «В симфонии воплощена философская проблема гармонии мира, человека и искусства. Отсюда - оппозиция сил pro et contra, кон- и диссонансов, конструкции - деструкции, симфонии - антисимфонии и направленность развития драматургии от фисгармонии к гармонии» [17, с. 85].

Фортепианный концерт (1979) Шнитке основан на концепции испытания идеи, выбора пути, поиска истины, отсюда - введение импровизационных эпизодов, символизирующих активно-действенное начало. Вообще, оппозиция консонанса и диссонанса, структуры и деструкции, мрачной гротесковой скерцозности и возвышенной лирики часто становилась темой произведений Шнитке, тяготевшего к глубоким философским концепциям в искусстве [15].

«Реквием» Э. Денисова (1980) иного рода. Он написан на немецкий, английский, французский текст Ф. Танцера и канонический латинский. В произведении автор представляет свой взгляд на вехи человеческой жизни между рождением и смертью (в цикле 5 частей от «Рождения улыбки» до «Креста»). Причем в последней части воплощается идея света: смерть трактуется как освобождение, единение с Богом, обретение вечности. Вообще тема света (света истины, Света Божьего) характеризует творчество Денисова в целом. Многие хоровые сочинения композитора «имеют особый смысл, это хоры “об исчезающей красоте”, в которых есть элемент "тихого прощания, тихого ухода". А понятия красоты и света являются ключевыми в эстетике Денисова» [11, с. 313]. Темой его творчества считается свет и тоска познавшего хрупкость неземной красоты, исчезающей и растворяющейся в звуках музыки.

Большая часть сочинений С. Губайдулиной прямо или косвенно связана с духовной тематикой. Так, пьеса «Descensio» (1981) ассоциируется с Днем сошествия Святого Духа на апостолов, отсюда - символическое последовательное регистровое «нисхождение» звучащего материала. В пьесах композитора велика роль символики и подтекстов, связанных с религиозной, философской, эстетической тематикой. В ее произведениях осмысливаются коренные категории и парадигмы Бытия (противопоставление Бога и человека, дихотомия формы и материи, антиномии добра и зла, света и тьмы, добродетели и греха). Характерны названия опусов Губайдулиной: «Шум и тишина», «Светлое и темное», «Крест-накрест», «Сад радости и печали», «Живое - неживое» и т.д. 
Кантата С. Губайдулиной «Ночь в Мемфисе» (1968) на древнеегипетские тексты в переводе А. Ахматовой, взятые из надгробных надписей, являет собой «интимное прикосновение к самому центру человеческого бытия - моменту смерти», который автору представлялся «самым важным в жизни» [16, с. 41]. Философской тематикой наполнена композиция «Час души» (1976) для симфонического оркестра, солирующих ударных и меццо-сопрано на стихи М. Цветаевой. Здесь полярные контрасты позитивной - лирической - и негативной - действенной - сфер очерчивают необъятный, бесконечный мир, в котором конфронтация сил добра и зла приводит к высшей гармонии, растворению личных коллизий во вселенских образах. Автор нашла в концепции своего сочинения аналогии с философией дзэн: «Не достигай добра и не отвергай зла!.. Ни с чем не утверждайся! Истина - созерцание. Она не в словах и книгах, но по ту сторону слов. Ее нельзя выучить, но надо пережить» [16, с. 183]. Связывая восточную философию с русской ментальностью, Губайдулина воплощает в «Часе души» идею вселенской добродетели и полной духовной самоотдачи человека миру, обществу, Богу. Только добро и свет даруют человеку вечность. Губайдулина рассматривает в своих произведениях фундаментальные антитезы бытия: рациональное - иррациональное, Запад - Восток, бренность - вечность, добро - зло, свет - тьма, космос - хаос, закон - беспорядок, - и в результате музыкального развития в ее опусах «побеждает» позитивная сфера образности, дающая человечеству надежду на будущее. Оппозиция сил интересует композитора с философской точки зрения: в музыке она воплощает собственную концепцию существования человека в XX столетии, близкую экзистенциализму С. Кьеркегора, религиозным идеям Н. Бердяева, мистическим взглядам М. Экхарта и др.

Обсуждение. Обратимся к педагогической практике, в частности к методам изучения и освоения семантики произведений русских композиторов второй половины XX века. Как правило, в курсах музыкально-исторических и теоретических дисциплин в вузах культуры и искусства применяются традиционные методы объяснительно-иллюстративного плана и формы лекции, беседы, семинара. Однако глубоко философские концепции симфоний требуют соответствующего глубокого познания, которое могут обеспечить методы герменевтического и интертекстуального анализа, применяемые в литературе, поэзии, а со второй половины XX века - и в музыке [1]. Музыкознание - одна из смежных наук, методология которой эффективно применяется в музыкально-педагогическом образовании. В музыкознании выработаны подходы, способствующие многостороннему изучению объекта исследования. Помимо этого в современной педагогике успешно апробированы такие инструменты познания, как метод мозгового штурма, активное и интерактивное обучение, проблемный метод и кейс-метод и т.д.

Авангардная музыка представляет собой превосходный материал для интеллектуальнотворческого и духовно-нравственного развития педагога-музыканта, исполнителя и просветителя и при этом сложный материал, требующий перечисленных выше инструментов познания, таких как метод мозгового штурма, активное и интерактивное обучение, кейс-метод и т.д. Приведем пример освоения семантически сложной авангардной музыки проблемным методом. Данный метод соответствует современной, личностно- и практико-ориентированной концепции образования [20, р. 720].

Через чисто религиозные жанры композиторы-авангардисты пришли к темам философского плана и общечеловеческого масштаба, глубоко познать которые удается только при условии активного включения в поиск решения проблемы. Ярким примером такого произведения служит «0фферторий» Губайдулиной - концерт для скрипки с оркестром, созданный в 1980 году (окончательная редакция - 1986). Концерт мыслился автором как часть инструментальной мессы, и главной идеей сочинения стало жертвование в широком смысле слова: как Христос принес себя в жертву человечеству, так и человечество должно принести себя в жертву красоте, совершенству, искусству. Перед студентами-музыкантами на семинарском занятии по истории и теории музыкального искусства была поставлена задача проанали- 
зировать нотный текст вплоть до каждого мотива и проследить процесс воплощения идеи жертвоприношения в звуковой ткани.

В произведении много звуковых символов и аллегорий. Во-первых, в разделе I, написанном в форме вариаций, 12-звучная тема постепенно уменьшается по протяженности до тех пор, пока от нее не остается лишь один звук. Так, тема, олицетворяющая человека, «приносит себя в жертву» - растворяется в общем музыкальном потоке. А в разделе III тема, напротив, постепенно наращивается от 1-го звука до 12-ти - так происходит возрождение человека, символическое воздаяние за принесенную жертву. Весь концерт мыслится Губайдулиной как мистерия, в которой человек проходит этапы «смерти» и «воскресения», благодаря жертве приобретает вечную жизнь. Ее символизирует «долгое и всеохватное финальное звучание благоговейного хорала - новый “шаг души” к просветлению» [16, с. 198]. К такому выводу студенты-музыканты неизбежно приходят, самостоятельно анализируя текст в поисках решения поставленной проблемы. Помогают им текстологический и интертекстуальный методы анализа семантики нотного материала, позволяющие выявить связь между конкретными мотивами, фразами, темами, гармониями, жанрово-стилевыми признаками и смысловыми значениями такого комплексного понятия, как «жертвоприношение».

В цикле на слова Г. Мистраль «Солнце инков» (1964) для сопрано и ансамбля Э. Денисов «воплощает идею взаимодействия двух тенденций формообразования - к определенности и к неопределенности» [7, с. 276]. В ходе разбора звукового текста становится очевидным, что уже первая часть при всей стабильности материала содержит мобильную партию ударных инструментов, символизирующих неживое в сравнении с голосом певицы, символизирующим душу человека. Неопределенность партии ударных развивается в следующих частях и переходит в другие партии, так что «в IV части две основные линии - голос и флейта - звучат на непрерывно меняющемся фоне струнных, и вновь возникает в большой коде, завершающей всё сочинение» [18, с. 277]. Возможно, полюс неопределенности связан с тремя, по мнению Шнитке, эмоционально-чувственными доминантами стихотворений поэтессы Г. Мистраль - усталой рефлексией, тревожными предчувствиями и ощущением трагических потрясений. В ходе анализа нотного материала и поиска ответов на поставленные вопросы обучающиеся обнаруживают, что в целом произведение построено на свободно используемой 12-тоновой серии, имеет четкую структуру, а инструментальные части цикла фактурно объединены развитием одной ритмоформулы. Однако в частях IV и VI тенденция к неопределенности приводит к мобильной алеаторной форме, символизирующей предчувствия трагических событий, образы багряной крови и пылающей вершины горы, отраженные в тексте вокальной партии.

Заключение. Музыка второй половины XX века не утратила, а только усилила исконно русские черты - интенцию к духовному началу, устремленность к коренным ценностям, очищение через общение с Богом и страдание, тягу к добродетели и свету, поиски нового облика красоты и идеала. «Главное, ни с чем не сравнимое приобретение в культуре XX столетия - осознание духовности как основы русской музыки, стоящей над любой идеологией. Количество партитур, воплощающих духовные смыслы разных религиозных конфессий, ныне настолько внушительно, что превышает всё, что было создано отечественными композиторами в этой сфере за предыдущие три четверти века. Эпилог XX столетия завершил трагический рисунок века поисками новых абрисов Красоты» [2, с. 155].

Русский авангард на глубоком уровне связан с наследием отечественной классической музыки и содержит духовно-нравственные доминанты народа, передаваемые из поколения в поколение и бережно хранимые художниками-творцами разных эпох. Причастность музыки к чему-то неизмеримо большему, чем прекрасное звучание, - Божественному началу, заключенному в глубинах человеческой души, придает особый смысл авангардной музыке России ушедшего столетия. Она еще больше приблизилась к пониманию совершенных законов бытия через размышления о них. 
Несмотря на обращение и свободное оперирование современными техниками письма и приемами звуковой выразительности, отечественные композиторы сохранили в своей музыке внутренние национальные черты, самые фундаментальные свойства славянской натуры - типично русскую серьезность отношения к жизни и искусству, характерный русский максимализм и сосредоточенность интеллекта и чувства на рассматриваемой проблеме, преломление в музыке глубоких концепций философии, религии, этики, эстетики, морали, живой человеческой мысли и чувства, высокую духовную ответственность в своей творческой деятельности и на жизненном пути. Познать всё это возможно посредством применения герменевтического, семантического и интертекстуального анализа, разработанного и широко используемого в музыкознании как науки, смежной с музыкальной философией, эстетикой и педагогикой.

\section{Список литературы}

1. Беляева-Экземплярская С. Музыкальная герменевтика // Искусство. Кн. 4. М.: Academia, 1927. C. 48-61.

2. Долинская Е.Б. 0 русской музыке последней трети XX века. Магнитогорск: Изд-во Магнит. гос. консерватории, 2000. 158 с.

3. Высоцкая М., Григорьева Г. Музыка XX века. От авангарда к постмодерну. М.: Моск. консерватория, 2011. $440 \mathrm{c}$.

4. История русской музыки: в 10 т. / редкол.: Ю.В. Келдыш, Л.О. Акопян, Л.З. Корабельникова и др. Т. 10Б: 1983-1990 годы. М.: Музыка, 2004. 469 с.

5. История современной отечественной музыки. Вып. 3. 1960-1990 / ред.-сост. Е.Б. Долинская. М.: Музыка, 2001. 656 с.

6. Левая Т. Русская музыка начала XX века в художественном контексте эпохи. М.: Музыка, 1991. 166 c.

7. Переверзева М.В. Алеаторика как принцип композиции: учеб. пособие. СПб.: Планета музыки : Лань, 2018. 608 с.

8. Переверзева М.В. Значение русской культуры в становлении культуры США // Художественное пространство культуры третьего тысячелетия: проблемы науки и образования: сб. науч. тр. ВШМ им. А. Шнитке (институт) РГСУ / отв. ред. Н.С. Ющенко. М.: РГСУ, 2018. C. 271-280.

9. Раабен Л. 0 духовном ренессансе в русской музыке 1960-80-х годов. СПб.: Бланка : Бояныч, 1998. 351 c.

10. Русская музыка и XX век / ред.-сост. М. Арановский. М.: ГИИ, 1997. 742 с.

11. Свет. Добро. Вечность. Памяти Эдисона Денисова. Статьи. Воспоминания. Материалы / ред.-сост. В. Ценова. М.: Моск. гос. консерватория им. П.И. Чайковского, 1999. 488 с.

12. Соколов А.С. Музыкальная композиция XX века: диалектика творчества. Исследование. М.: Композитор, 2007. 272 c.

13. Солженицын А. Россия в обвале. 3-е изд. М.: Русский путь, 1998. 206 с.

14. Теория современной композиции / отв. ред. В.С. Ценова. М.: Музыка, 2005. 624 С.

15. Холопов Ю.Н., Ценова В.С. Эдисон Денисов. М.: Композитор, 1993. 312 с.

16. Холопова В. София Губайдулина: монография. 2-е изд., доп. М.: Композитор, 2008. 400 с.

17. Холопова В.Н., Чигарева Е.И. Альфред Шнитке. Очерк жизни и творчества. М.: Советский композитор, 1990. 350 c.

18. Шнитке А. Эдисон Денисов // Свет. Добро. Вечность. Памяти Эдисона Денисова. Статьи. Воспоминания. Материалы: сб. тр. / ред.-сост. В. Ценова. М.: Моск. гос. консерватория, 1999. C. 272-289.

19. Davydova A.A., Lushnikov S.S., Pereverzeva M.V., Smirnov A.V., Tsarev D.V. Piano music of composers-minimalists in the teaching repertoire of higher music education // Opcion. 2018. No. 34 (Special Issue 17). P. 149-162.

20. Pereverzeva M., Anufrieva N., Avramkova I., Korsakova I., Shcherbakova A. Orientation of musical disciplines as a condition for the formation of competencies // Opcion. 2018. No. 34 (Special Issue 17). P. 719-730.

\section{References}

1. Belyaeva-Ekzemplyarskaya S. Muzykal'naya germenevtika // Iskusstvo. Kn. 4. M.: Academia, 1927. S. 48-61. 
2. Dolinskaya E.B. 0 russkoj muzyke poslednej treti XX veka. Magnitogorsk: Izd-vo Magnit. gos. konservatorii, 2000. $158 \mathrm{~s}$.

3. Vysockaya M., Grigor'eva G. Muzyka XX veka. Ot avangarda k postmodernu. M.: Mosk. konservatoriya, 2011. $440 \mathrm{~s}$.

4. Istoriya russkoj muzyki: $v 10$ t. / redkol.: Yu.V. Keldysh, L.O. Akopyan, L.Z. Korabel'nikova i dr. T. 10B: 1983-1990 gody. M.: Muzyka, 2004. 469 s.

5. Istoriya sovremennoj otechestvennoj muzyki. Vyp. 3. 1960-1990/ red.-sost. E.B. Dolinskaya. M.: Muzyka, 2001. $656 \mathrm{s.}$

6. Levaya T. Russkaya muzyka nachala XX veka $v$ khudozhestvennom kontekste epokhi. M.: Muzyka, 1991. $166 \mathrm{s.}$

7. Pereverzeva M.V. Aleatorika kak princip kompozicii: ucheb. posobie. SPb.: Planeta muzyki : Lan', 2018. $608 \mathrm{~s} .^{2}$

8. Pereverzeva M.V. Znachenie russkoj kul'tury v stanovlenii kul'tury SShA // Khudozhestvennoe prostranstvo kul'tury tret'ego tysyacheletiya: problemy nauki i obrazovaniya: sb. nauch. tr. VShM im. A. Shnitke (institut) RGSU / otv. red. N.S. Yushchenko. M.: RGSU, 2018. S. 271-280.

9. Raaben L. 0 dukhovnom renessanse $v$ russkoj muzyke 1960-80-kh godov. SPb.: Blanka : Boyanych, 1998. $351 \mathrm{~s}$.

10. Russkaya muzyka i XX vek / red.-sost. M. Aranovskij. M.: GII, 1997. 742 s.

11. Svet. Dobro. Vechnost'. Pamyati Edisona Denisova. Stat'i. Vospominaniya. Materialy / red.sost. V. Cenova. M.: Mosk. gos. konservatoriya im. P.I. Chajkovskogo, 1999. $488 \mathrm{~s}$.

12. Sokolov A.S. Muzykal'naya kompoziciya XX veka: dialektika tvorchestva. Issledovanie. M.: Kompozitor, 2007. $272 \mathrm{~s}$.

13. Solzhenicyn A. Rossiya v obvale. 3-e izd. M.: Russkij put', 1998. $206 \mathrm{s.}$

14. Teoriya sovremennoj kompozicii / otv. red. V.S. Cenova. M.: Muzyka, 2005. $624 \mathrm{s.}$

15. Kholopov Yu.N., Cenova V.S. Edison Denisov. M.: Kompozitor, 1993. $312 \mathrm{~s}$.

16. Kholopova V. Sofiya Gubajdulina. Monografiya. 2-e izd., dop. M.: Kompozitor, 2008. $400 \mathrm{~s}$.

17. Kholopova V.N., Chigareva E.I. Al'fred Shnitke. Ocherk zhizni i tvorchestva. M.: Sovetskij kompozitor, 1990. $350 \mathrm{~s}$.

18. Shnitke A. Edison Denisov // Svet. Dobro. Vechnost'. Pamyati Edisona Denisova. Stat'i. Vospominaniya. Materialy: sb. tr. / red.-sost. V. Cenova. M.: Mosk. gos. konservatoriya, 1999. S. 272-289.

19. Davydova A.A., Lushnikov S.S., Pereverzeva M.V., Smirnov A.V., Tsarev D.V. Piano music of composers-minimalists in the teaching repertoire of higher music education // Opcion. 2018. No. 34 (Special Issue 17). P. 149-162.

20. Pereverzeva M., Anufrieva N., Avramkova I., Korsakova I., Shcherbakova A. Orientation of musical disciplines as a condition for the formation of competencies // Opcion. 2018. No. 34 (Special Issue 17). P. 719-730.

\section{Библиографическое описание статьи / Reference to article}

Мелешкина Е.А., Жилина А.В. Семантические доминанты русского музыкального авангарда в курсе музыкально-исторических дисциплин вузов // Ученые записки Российского государственного социального университета. Т. 19. 2020. № 1 (154). С. 160-167. D0I: 10.17922/2071-5323-2020-19-1-160-167 (Библиографическое описание согласно российским стандартам).

Meleshkina E.A., Zhilina A.V. Semanticheskie dominanty russkogo muzykal'nogo avangarda $\checkmark$ kurse muzykal'no-istoricheskikh disciplin vuzov // Uchenye zapiski Rossijskogo gosudarstvennogo social'nogo universiteta. T. 19. 2020. № 1 (154). S. 160-167. DOI: 10.17922/2071-5323-2020-19-1-160-167 (Reference in Roman script).

Meleshkina, E.A. \& Zhilina, A.V. (2020) Semantic Dominants of Russian Musical Vanguard in the Course of Musical and Historical Disciplines of Higher Education Institutions, Scientific Notes of Russian State Social University. Vol. 19. No. 1 (154). P. 160-167. D0I: 10.17922/20715323-2020-19-1-160-167 (International bibliographic description). 
Свидетельство о регистрации средства массовой информации в Федеральной службе по надзору за соблюдением законодательства в сфере массовых коммуникаций и охране культурного наследия ПИ № ФС 77-26246 от 17.11.2006

Подписано в печать 30.03.2020

Формат бумаги 70×100 1/16. Гарнитура «0фисная». Усл. печ. л. 13,96

Тираж 2000 экз.

Издательство Российского государственного социального университета.

129226, Москва, ул. В. Пика, д. 4.

Тел.: 8 (495) 255-67-67 (доб. 30-06).

www.rgsu.net

Отпечатано в типографии

Российского государственного социального университета.

129226, Москва, ул. В. Пика, д. 4.

Тел.: 8 (495) 255-67-67 (доб. 30-40).

Заказ № 20-5 